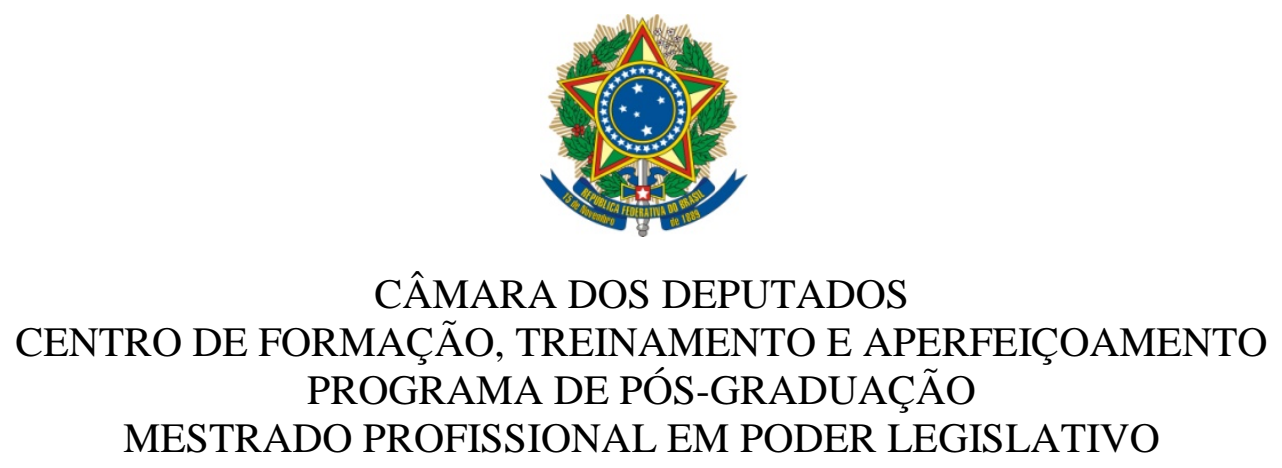

MARCOS AURÉLIO PEREIRA

APRECIAÇÃO DE VETOS PRESIDENCIAIS PELO CONGRESSO NACIONAL BRASILEIRO: PODER DE AGENDA DO LEGISLATIVO, NÃO DECISÃO, E OBSOLESCÊNCIA DO VETO

Brasília 


\title{
APRECIAÇÃO DE VETOS PRESIDENCIAIS PELO CONGRESSO NACIONAL BRASILEIRO: PODER DE AGENDA DO LEGISLATIVO, NÃO DECISÃO, E OBSOLESCÊNCIA DO VETO
}

\author{
Trabalho de Conclusão de Curso \\ apresentado como requisito parcial para a obtenção do \\ grau de Mestre no Curso de Mestrado Profissional do \\ Programa de Pós-Graduação do Centro de Formação, \\ Treinamento e Aperfeiçoamento da Câmara dos \\ Deputados/CEFOR.
}

Orientador: Maurício Schneider

Área de Concentração: Poder Legislativo

Linha de Pesquisa: Processos Políticos do Poder Legislativo

\section{Brasília}




\section{Autorização}

Autorizo a divulgação do texto completo no sítio da Câmara dos Deputados e a reprodução total ou parcial, exclusivamente, para fins acadêmicos e científicos.

Assinatura:

Data:

Pereira, Marcos Aurélio.

Apreciação de vetos presidenciais pelo Congresso Nacional brasileiro [manuscrito] : poder de agenda de legislativo, não decisão, e obsolescência do veto / Marcos Aurélio Pereira. - 2016.

$161 \mathrm{f}$.

Orientador: Maurício Schneider.

Impresso por computador.

Dissertação (mestrado) - Câmara dos Deputados, Centro de Formação, Treinamento e Aperfeiçoamento (Cefor), 2016.

1. Veto, Brasil, 1988-2014. 2. Processo legislativo, Brasil. 3. Separação de poderes, Brasil. I. Título.

CDU 342.515(81) 


\section{APRECIAÇÃO DE VETOS PRESIDENCIAIS PELO CONGRESSO NACIONAL BRASILEIRO: PODER DE AGENDA DO LEGISLATIVO, NÃO DECISÃO, E OBSOLESCÊNCIA DO VETO}

Trabalho de Conclusão do Curso de Mestrado Profissional em Poder Legislativo

Marcos Aurélio Pereira

Banca Examinadora:

\begin{tabular}{c} 
Maurício Schneider \\
Presidente \\
Orientador - Câmara dos Deputados \\
\hline Examinador Interno - Câmara dos Deputados \\
Ricardo de João Braga \\
Examinador Externo - Senado Federal
\end{tabular}

Suely Mara Vaz Guimarães de Araújo - Câmara dos Deputados Suplente

Brasília, 3 de março de 2016. 
Dedico este produto a Maria e Custódio, amados e reverenciados senhores dos meus começos e fontes de minha firme noção de gratidão. Por meio deles dedico tudo o que faço à menor e maior de todas as instituições: Família. Aos raros e valorosos entes angelicais a que chamo amigos, que compreendem o isolamento dos estudos dedicados, e jamais desistem de nutrir a verdadeira amizade. A Olair, namorado e amigo, pela leveza e a pureza com que perfuma minhas rotinas. 


\section{Agradecimentos}

Agradeço aos professores do CEFOR pela crença na empreitada do mestrado profissional, e pela compreensão e companheirismo nas situações do calendário anômalo desenvolvido. Ao Senado Federal, agradeço pelas concessões e principalmente pelos colegas com que me presenteou. 
"The real problem of humanity is the following: we have paleolithic emotions; medieval institutions; and God-like technology. And it is terrifically dangerous, and it is now approaching a point of crisis overall."

Edward O. Wilson 


\section{RESUMO}

A presente dissertação analisa o processo decisório legislativo de vetos presidenciais pelo Congresso Nacional, no período de 1988 a 2014, para responder às seguintes questões: O que a não decisão do Congresso diz sobre o Legislativo, o sistema político e o veto? Quando e como o Congresso decidiu sobre vetos? As hipóteses formuladas são: o Legislativo exerceria seu poder de agenda ao inovar regras e procedimentos e ao não decidir; e o veto padeceria de obsolescência para o sistema político concreto. Para tanto se consideraram os 1.160 vetos presidenciais apostos no período analisado, bem como o comportamento das sete legislaturas pós-constitucionais que os apreciaram, em 263 sessões de vetos, descrevendo-se o percurso histórico do instituto e das regras e procedimentos utilizados no processo decisório de veto. Por meio dos resultados de apreciação, analisa-se o fenômeno de não decisão, diretamente vinculado ao efeito de decadência do instituto para o sistema brasileiro de separação de poderes. Ao final corroboram-se as hipóteses de obsolescência do instituto juspolítico do veto, se bem que em face de valores prescritos para o sistema de separação de poderes no presidencialismo, sendo também esclarecidos e avaliados os mecanismos do exercício concreto de poder de agenda do Legislativo, para o processo decisório em questão. Conclui-se que a apreciação do veto presidencial expressa um conflito evitado, arena deserta, fato mensurado pela não decisão congressual, expressa em estoques crescentes de vetos não votados, ou ainda pela votação de estoques frios, mas também que as alterações institucionais de regras e procedimentos, embora não tenham solucionado o acúmulo de estoques de vetos não apreciados, apontam para uma postura reativa do Legislativo, em face de um Poder Executivo preponderante. Contribui-se com essas conclusões para a teoria da separação dos poderes, bem como para os estudos dos processos decisórios legislativos em

democracias presidencialistas. Adicionalmente, oferece-se o mais abrangente inventário dos 1.160 vetos Presidenciais desde 1988.

Palavras-chaves. Veto presidencial; Exercício de poder de agenda; Não decisão; Processo decisório legislativo; Sistema de separação dos poderes. 


\begin{abstract}
This dissertation analyzes the legislative decision-making process of the National Congress for presidential vetoes cast during the 1988-2014 period, to answer the following questions: what the Congress non-decision tell about Legislative branch, the political system and the veto itself? When and how the Congress decided about vetoes? The hypotheses formulated are: the Legislative exercise its agenda power by innovating rules and procedures and by not deciding; and the veto is obsolescent for the concrete political system. To answer to these questions all 1.160 presidential vetoes cast in the analyzed period were considered, as well as the behavior of all the seven post constitutional legislatures, in appreciating them, in 263 joint sessions, describing the historical path of the veto as well as the rules and procedures applied in its decision-making process. By the results of its appreciation the phenomenon of non-decision, directly linked to the decadence of the veto for the Brazilian separation of powers system, is analyzed. As a result the main hypotheses are confirmed, notably the obsolescence of the veto although it is so only when it is faced with the values prescribed for the presidentialist system of separation of powers, as well as the mechanisms of concrete exercise of legislative agenda power for this legislative decision-making process are clarified. It is concluded that the appreciation of the presidential veto express an avoided conflict does not explain more conflicts in the Brazilian political system, a fact illustrated by non-decision, expressed by rising vetoes stocks, and by the voting of cold stocks, and also that institutional alterations on rules and procedures solutions may have not solved the accumulation of not voted vetoes stocks, but point to a more reactive behavior of the Legislative, in face of a predominant Executive branch. These conclusions contribute both with the separation of powers theory and studies of legislative decision-making procedures in presidential democracies. Additionally, the most comprehensive inventory of Presidential vetoes since 1988 is provided.
\end{abstract}

Keywords. Presidential veto. Agenda power. Non-decision. Legislative decision-making process. Separation of powers system. 


\section{LISTA DE FIGURAS, QUADROS E TABELAS}

\section{LISTA DE FIGURAS}

Figura 1: Processo Decisório Legislativo da lei ordinária...........................................................33

Figura 2: Fluxo de Informação no Processo Decisório Legislativo de Veto - Executivo............... 34

Figura 3: Fluxo de Informação no Processo Decisório Legislativo de Veto - Legislativo..............35

Figura 4: Gráfico das sessões mensais efetivas em 1990 (março em diante)..................................68

Figura 5: Gráficos das sessões efetivas de vetos - legislaturas ano a ano......................................69

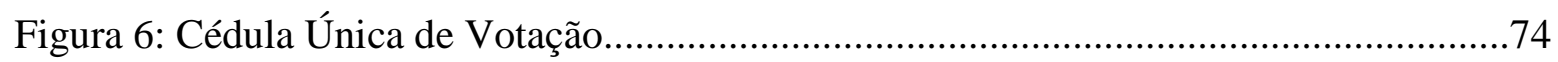

Figura 7: Gráfico reedições de medidas provisórias e sessões de vetos.........................................80

Figura 8: Gráfico sessões conjuntas deliberativas, com vetos e efetivas $48^{\mathrm{a}}-51^{\mathrm{a}}$ Legislaturas......83

Figura 9: Gráfico de estoques transferidos à legislatura seguinte $-48^{\mathrm{a}}-51^{\mathrm{a}}$ Legislaturas................84

Figura 10: Captura de tela ilustrando parte da planilha das sessões de apreciação de veto............94

Figura 11: Captura de tela "histórico” de apreciação de vetos.........................................................95

Figura 12: Captura de tela ilustrando a planilha dos vetos..........................................................96

Figura 13: Gráfico de não decisão por legislatura, conforme estoques........................................116

Figura 14: Gráfico de vetos: 1988-2014 - Emissões, Estoques e Resoluções..............................117

Figura 15: Gráfico da Produção Anual de Leis 1988-2014.......................................................141

Figura 16: Gráfico das Dificuldades de Quórum na 48ª e 49 Legislaturas..................................143

Figura 17: Gráfico de Vetos, classificados por tipo.................................................................146

Figura 18: Gráfico de Vetos, por modalidade de votação............................................................147

Figura 19: Gráficos dos Temas da Matéria Vetada - Autoria do Executivo 1988-2014..............151

Figura 20: Gráficos dos Temas da Matéria Vetada - Autoria do Legislativo - 1988-2014..........151

Figura 21: Gráfico de Vetos Rejeitados, classificados por legislatura........................................157

Figura 22: Gráficos de legislatura de apreciação do veto - conforme resultado............................158

Figura 23: Gráficos de vetos rejeitados por tipo e períodos........................................................159 


\section{LISTA DE QUADROS}

Quadro 1: Regulamentações Constitucionais do Veto no Brasil...............................................54

Quadro 2: Percentual de Resolução de Vetos - Com Estoques - 48 à 50a Legislaturas...............79

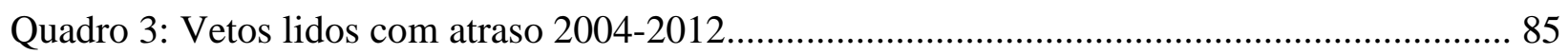

Quadro 4: Percentual de Resolução de Vetos $-48^{\mathrm{a}}$ à $54^{\mathrm{a}}$ Legislaturas.......................................91

Quadro 5: Alterações Institucionais do processo decisório de vetos........................................106

Quadro 6: Agenda eleitoral e políticoeconômica...................................................................107

Quadro 7: Partidos nas Presidências do Congresso e da República..........................................110

Quadro 8: Presidentes do Congresso - Sessões Efetivas.......................................................144

Quadro 9: Vetos Rejeitados - Tema Administrativo - Assuntos............................................154

Quadro 10: Vetos Rejeitados - Tema Econômico - Assuntos...................................................156

Quadro 11: Vetos Rejeitados - Temas Jurídico e Social - Assuntos.........................................156

Quadro 12:Vetos Rejeitados pela Câmara e Mantidos pelo Senado.........................................160

\section{LISTA DE TABELAS}

Tabela 1: Sessões: 1988-2014 - Resolução de Vetos - 48 a ${ }^{\mathrm{a}}$ a ${ }^{\mathrm{a}}$ Legislaturas.............................89

Tabela 2: Apreciação do veto - 1988-2014..........................................................................111

Tabela 3: Sessões: 1988-2014 - Não Decisão Simples...........................................................112

Tabela 4: Sessões: 1988-2014 - Não Decisão com Apreciação de Estoques Herdados...............113

Tabela 5: Sessões: 1988-2014 - Não Decisão sem Contabilização de Estoques Herdados.........114

Tabela 6: Sessões: 1988-2014 - Resolução de Vetos - sem o estoque - 51 a e 52 ${ }^{\mathrm{a}}$ Legislaturas...114

Tabela 7: Leis e Vetos - Primeiro e Segundo Períodos Democráticos.....................................139

Tabela 8: Vetos Presidenciais no Brasil: 1988-2014 - Presidente autor....................................148

Tabela 9 Vetos Presidenciais no Brasil: 1988-2014 - Autor vetado..........................................149

Tabela 10: Vetos Presidenciais no Brasil: 1988-2014 - Tema da matéria vetada.......................150

Tabela 11: Vetos Presidenciais no Brasil: 1988-2014 - Resultado da Apreciação......................153

Tabela 12: Vetos Presidenciais no Brasil: 1988-2014 - Tempo de Tramitação......................... 154 


\section{SUMÁRIO}

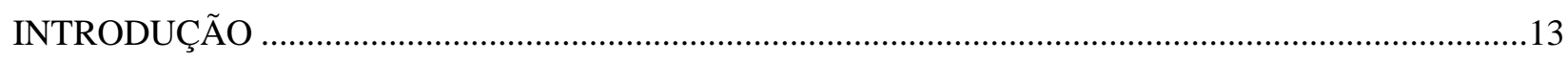

1 - REVISÃO BIBLIOGRÁFICA E BASE TEÓRICA...........................................................................19

1.1 Base teórica: institucionalismo da escolha racional.............................................................. 20

1.2 Poder de Agenda ............................................................................................................. 23

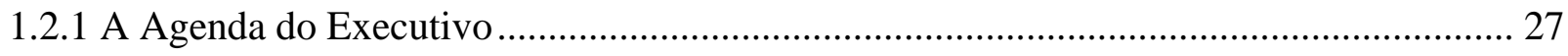

1.2.2 A Agenda do Legislativo ……………………………............................................. 29

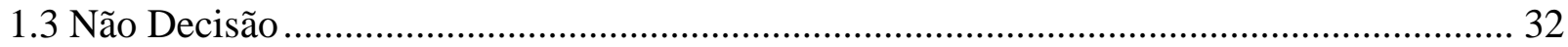

1.3.1 Processo legislativo do veto como processo decisório …………………………………...... 32

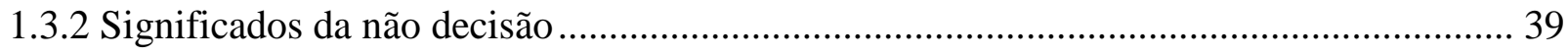

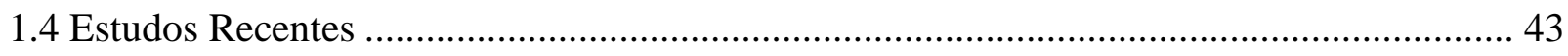

2 - EVOLUÇÃO HISTÓRICA, REGRAS E PROCEDIMENTOS ...........................................................49

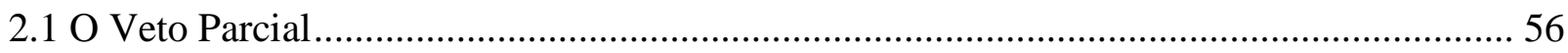

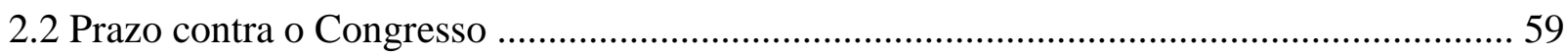

2.3 O veto da Constituição de 1988 ............................................................................................ 60

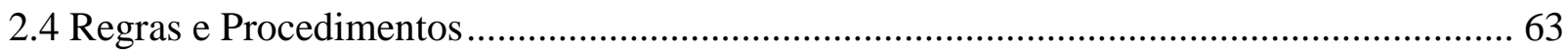

2.4.1 48 $8^{\mathrm{a}}$ Legislatura (1988 (outubro) - 1990)............................................................................. 66

2.4.2 49 $9^{\mathrm{a}}$ Legislatura (1991-1994) ......................................................................................... 71

2.4.3 50 Legislatura (1995-1998)........................................................................................ 78

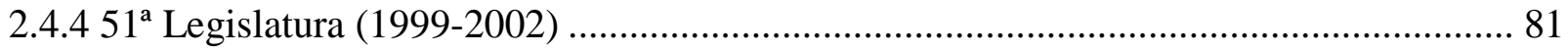

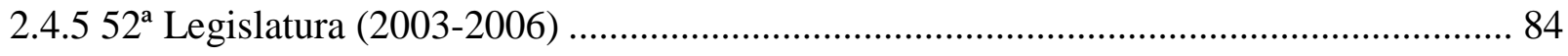

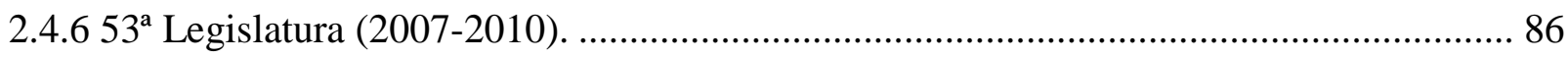

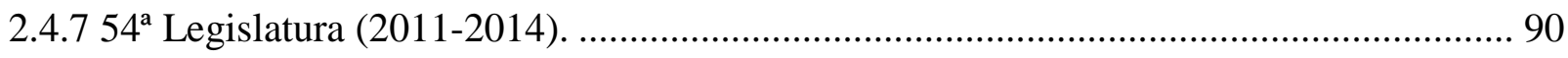

3 - METODOLOGIA ………………………………………………………………………99

3.1 Obtenção dos dados ......................................................................................................... 93 


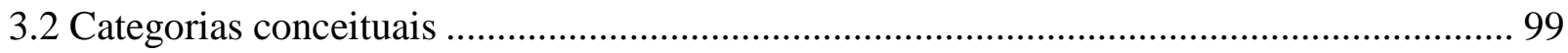

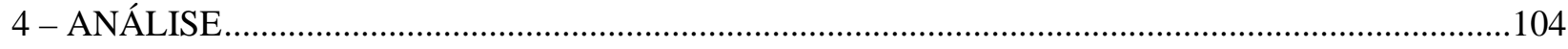

4.1 Explicando as alterações institucionais do processo decisório de veto. .......................... 104

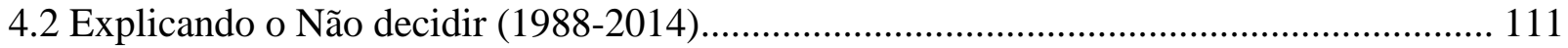

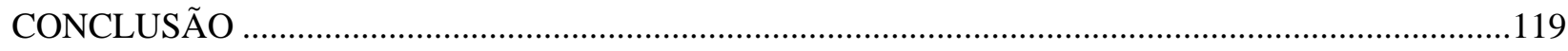

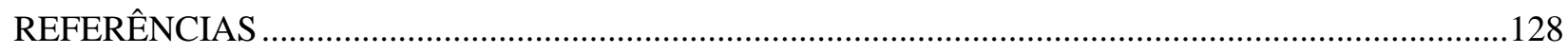

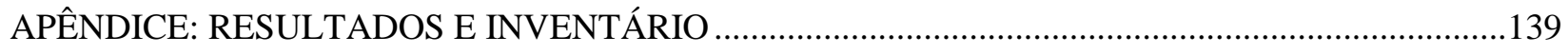

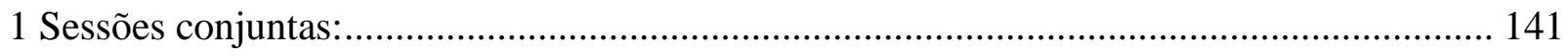

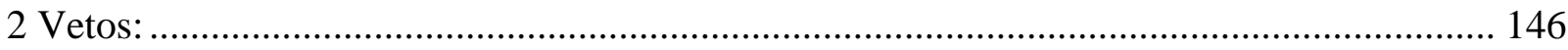

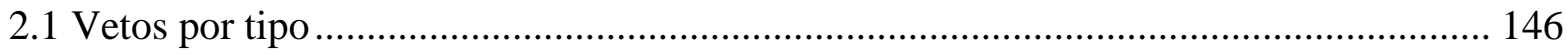

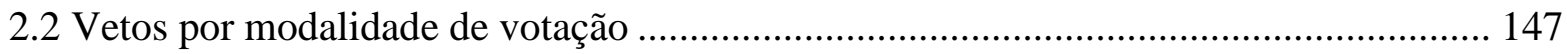

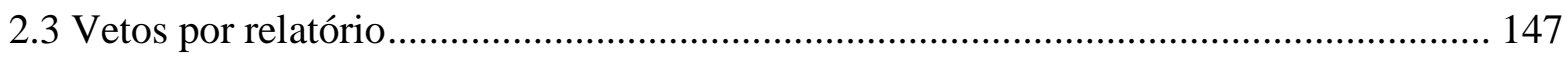

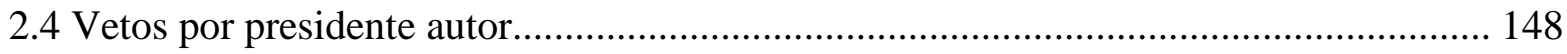

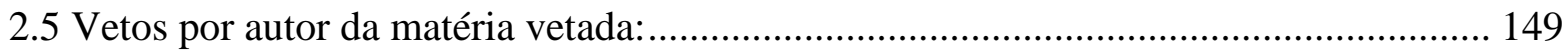

2.6 Vetos pelo tema da matéria vetada...................................................................... 150

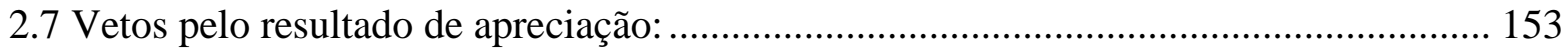

2.8 Vetos pelo tempo de tramitação: ............................................................................ 154

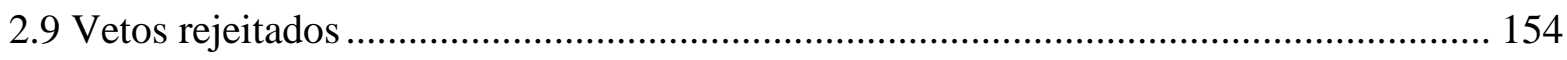

2.10 Quase rejeição e vetos mútuos.......................................................................... 160 


\section{INTRODUÇÃO}

A Constituição brasileira de 1988 (BRASIL, 1988) elenca um conjunto considerável de prerrogativas e poderes ao Presidente da República no tocante ao poder de legislar. Entre os mais importantes encontram-se as iniciativas exclusivas de propositura de projetos de lei, prerrogativa de imprimir urgência a projetos em tramitação, poder de decreto (medidas provisórias com efeito imediato de lei), e poder de veto total e parcial.

O texto constitucional, no capítulo referente à organização dos poderes, estabelece regras gerais de processo legislativo, entre as quais os casos de sessões conjuntas, em que deputados e senadores votam a mesma pauta legislativa. Entre as matérias de competência legislativa conjunta encontram-se os vetos presidenciais. Sua tramitação está regrada pela Constituição (BRASIL, 1988) e pelo Regimento Comum do Congresso Nacional (BRASIL, 1970). Segundo este arcabouço, o Congresso dispõe de um curto prazo de trinta dias para resolver sobre o veto, a partir de recebimento, após os quais ocorreria o sobrestamento da pauta das sessões conjuntas.

Sob o ponto de vista estritamente jurídico do processo legislativo, o ato de vetar faz parte da fase constitutiva da lei (SILVA, 2006; FERREIRA FILHO, 2002), a qual tem lugar em órgão diverso do Parlamento. Sob a óptica constitucional, os poderes Legislativo e Executivo, em concurso de vontades, decidem sobre como será a legislação (PEREIRA, 2014), sendo o veto a expressão de um conflito evidente entre os dois poderes quanto a alterações do status quo legal.

Conforme a consagrada concepção de Montesquieu de tripartição equilibrada do poder do Estado, ao vetar o Executivo exerce um “freio”, em função atípica, sobre o Legislativo, no exercício de sua função típica, conforme o Presidente da República conceba, para cada caso concreto, uma inconveniência de ordem pública ou um vício jurídico na formação da lei. O veto é, portanto, uma necessidade decorrente da tripartição do poder, sob o argumento central de que aquele que faz a lei não pode executá-la, ou poderia haver tirania (CASASANTA, 1937), uma concepção que prefere a separação estrita de funções. 
Quando o veto ocorre, estabelece-se, ao menos em princípio, um conflito entre os dois poderes. Quando ele é total, essa discordância tolhe a iniciativa legiferante de modo integral, como se a própria ementa fosse vetada. Quando parcial, a parte sancionada é imediatamente promulgada, já alterando o status quo; em ambos os casos, retorna o veto para a apreciação do Legislativo. Por essa apreciação seria possível mensurar não somente a discordância do Legislativo quanto a certos conteúdos, mas também a disciplina da base da coalizão legislativa presidencial.

Após a instauração do regime constitucional de 1988, os procedimentos de tramitação do veto vêm sofrendo alterações, com impactos prováveis sobre o resultado do desempenho do Poder Legislativo em face do poder de veto do Executivo. Desde a votação secreta, por painel eletrônico, passando pelas cédulas únicas de votação, até voto aberto de hoje, por meio de painel ou cédula, essa trajetória do procedimento legislativo pode revelar aspectos significativos do exercício do poder de agenda, bem como da função que o instituto do veto exerce no sistema político baseado na separação dos poderes. Ocorre, no entanto, que mesmo diante dessas inovações, a apreciação de vetos permaneceu sendo realizada de modo raro e anômalo, revelando uma postura que pode ser interpretada como contrária à sua função institucional.

Ao tempo em que se avulta em importância o exercício de atividade legiferante do Executivo, por meio de medidas provisórias e do exercício do poder de veto, cresce também o ativismo do Judiciário, que vem se tornando palco cada vez mais preferencial de efervescência social na solução de questões deixadas a decidir pelo próprio Legislativo. De outra ponta, a função de controle e fiscalização, exercida com o auxílio do Tribunal de Contas da União, acontece com inversão de papéis, em que o Poder Legislativo acaba se comportando como homologador das decisões da Corte de Contas. Por fim, a própria função parlamentar de expressar-se por meio da oratória não tem a repercussão de outrora, sendo a figura do "orador de tribuna” facilmente tragada pelas dos chamados "blogueiros”, pela imprensa em suas diversas mídias, entre outros atores da sociedade contemporânea. Eis porque as análises dos resultados dos poderes Legislativos estão sempre potencialmente carregadas de valores e julgamentos concernentes à legitimidade desses ramos de poder.

Partindo-se da compreensão de que o veto somente pode ser visto como tal quando praticado pelo Executivo e apreciado pelo Legislativo, e diante da acumulação constante de 
estoques de vetos não apreciados, mesmo em face de um comando constitucional singelo, tornase premente responder às seguintes perguntas: o que a não decisão do Congresso diz sobre o Legislativo, o sistema político e o veto? Quando e como o Congresso decidiu sobre vetos?

O presente estudo trata especificamente do instituto juspolítico do veto, positivado no texto da Constituição de 1988 (BRASIL, 1988), pela perspectiva do procedimento legislativo. Preocupa-se em contribuir para descrições e reflexões sobre o comportamento do Congresso na decisão sobre vetos, sobre o poder de agenda do Poder Legislativo, contribuindo para a compreensão do veto como local de conflito entre o Legislativo e Executivo.

Sua relevância justifica-se pela relativa escassez de estudos teóricos e empíricos sobre a apreciação do veto presidencial, dentre os quais se destacam as teses de Grohmann (2003), Lamounier (2005), e Moya (2005), que guardam entre si o interesse comum de explicar o veto presidencial pela perspectiva de sua produção. As variáveis escolhidas por esses autores oferecem modelos explicativos para a previsibilidade e incidência do veto, bem como explicam seu status institucional de ferramenta de reforço do poder de agenda do Presidente da República. Independentemente da natureza da variável, exógena ou endógena, o que se mensura é a produção, previsibilidade, ou incidência, do veto.

O que se oferece é a perspectiva inversa, ao investigar o regime de efetiva apreciação do veto presidencial pelo Congresso. Objetiva-se, a partir da questão inicial de mora deliberativa, explicitar o percurso das alterações procedimentais que levaram à incidência de diversos recursos regimentais (prejudicialidade, urgência, cédula de votação, entre outros) aplicados à tramitação de vetos, bem como checar os efeitos desse estado de coisas sobre o próprio instituto do veto. Quais seriam, afinal, os efeitos do comportamento do Poder Legislativo no processo decisório de veto sobre o sistema politico e sobre o próprio instituto de veto.

Objetiva-se, com essa explicação compreender como o Legislativo exerce seu poder de agenda, por meio da expressão concreta de apreciação de vetos, bem como verificar os sinais da obsolescência do instituto, fato que seria cíclico, no entender de Britto (1966) ${ }^{1}$. O estudo

\footnotetext{
${ }^{1} \mathrm{O}$ autor prefere o termo "decadência” do veto, ao desenvolver uma teoria do veto. A causa seria o fortalecimento do Executivo, "herdeiro direto dos monarcas [...]”. (p. 12).
} 
compreende o período desde a promulgação da Constituição em 1988 (BRASIL, 1988), até o ano de 2014, abrangendo, portanto, sete Legislaturas ( $48^{\mathrm{a}}$ a $\left.54^{\mathrm{a}}\right)$.

O locus de observação do fenômeno é o procedimento legislativo, no sentido de Olivetti (1998), levado a efeito no Congresso Nacional brasileiro. Embora seja interessante apontar as repercussões para o sistema Executivo-Legislativo, unidade analítica preferencial da ciência política pátria, concentram-se esforços explicativos nas soluções encontradas pelo próprio Congresso para lidar com a reconhecida superioridade instrumental do Poder Executivo (MOYA, 2005). Espera-se oferecer um quadro descritivo e analítico suficiente para testar as hipóteses centrais: o veto é instituto juspolítico obsoleto no sistema de separação dos poderes previsto para o modelo clássico, e o Poder Legislativo exerce seu próprio poder de agenda lançando mão de recursos variados disponíveis para dispor sobre sua ordem do dia.

A hipótese relativa à obsolescência apoia-se em duas suposições: a noção inicial de que a apreciação do veto presidencial deveria explicar o conflito entre Executivo e Legislativo, noção que se contrapõe ao fenômeno de não decisão. Se, conforme Britto (1966) a função do veto é de legitimação do conflito admitido, um sistema de separação de poderes pouco nítido seria ambiente apropriado para o enfraquecimento do instituto; a segunda suposição é a de que o instituto pode não mais corresponder às razões de seu surgimento, em razão da existência de um sistema modificado de separação de poderes.

A hipótese relativa ao poder de agenda leva em conta a noção de que o Poder Legislativo é o órgão constitucional formador do direito legislado, e como tal, tende a manter guarda sobre essa prerrogativa, mesmo em contextos de governos de coalizão, em que a agenda é fundida, ou compartilhada. Isso quer dizer também que, por vias procedimentais heterodoxas, o Legislativo se capacitaria a promover o debate, se não pelos conteúdos, ao menos por seus tempos e termos.

Para situar o presente estudo entre as contribuições da ciência política pátria, recorre-se ao levantamento de Santos (2008), que mapeia o esforço coletivo nacional na empresa acadêmica de explicar as instituições políticas sob a ordem constitucional de 1988. Depois da detecção de forte influência exercida pelos estudos do congresso norte-americano, o autor procede a uma “entrevista” com a literatura do período de 1994 a 2005. Em sua amostra, ele situa os esforços conforme sua base teórica, metodológica e empírica. 
Quanto à base teórica, a partir das variáveis explicativas endógenas e exógenas que elenca, Santos (2008) agrupa os 45 trabalhos de sua amostra em três grupos: modelos de arena Executivo-Legislativo, modelos de arena eleitoral e modelos de dupla arena. Ao final detecta haver a tendência de mais estudos de dupla arena.

O presente estudo insere-se no contexto teórico das pesquisas que tratam do processo decisório político concretizado no procedimento legislativo, em contexto de arena ExecutivoLegislativo, com ênfase, porém, na ação do próprio Legislativo, mais do que na relação entre os poderes. Não se trata de uma análise comparativa, mas de um aporte à explicação do comportamento legislativo pelo viés das decisões procedimentais concretas para o veto.

No que tange as escolhas metodológicas, Santos (2008) detecta a predominância de metodologias estatísticas descritivas, bem como a raridade da ocorrência dos modelos baseados na teoria dos jogos e nos modelos espaciais. Sob esse aspecto, o presente estudo soma-se à tendência à descrição de maior parte dos estudos da ciência política brasileira.

Finalmente, quanto à base empírica, o autor registra as pequenas dimensões das séries históricas pesquisadas, sendo que quase metade dos estudos não passa de duas legislaturas. A presente dissertação beneficia-se da estabilidade do regime democrático estabelecido pela Constituição de 1988 (BRASIL, 1988), oferecendo uma análise que abrange um período de 27 anos (sete legislaturas), compreendendo o mandato de seis presidentes da República, bem como a atuação de seis legislaturas eleitas democraticamente.

Quatro capítulos organizam o texto. O Capítulo 1 apresenta e detalha o referencial teórico-bibliográfico, apresentando a base teórica empregada, o institucionalismo da escolha racional, descrevendo as categorias teóricas Poder de Agenda e Não Decisão, e apresentando a bibliografia mais recente sobre vetos.

O Capítulo 2 oferece um sobrevoo histórico do veto, de sua origem até a formatação dada pela Constituição de 1988, seguido, a partir daí, da narrativa do exercício concreto do poder de agenda do Legislativo por meio das regras e procedimentos, explicitando as soluções empregadas pelas sete legislaturas estudadas no exercício desse poder. Estabelecido esse panorama teórico e histórico-descritivo, o Capítulo 3 detalha a metodologia aplicada, detalhando as ferramentas de 
pesquisa empregadas na prospecção, organização e análise dos dados, bem como justificando as escolhas por categorias conceituais consideradas mais relevantes.

Propõe-se a discussão dos principais dados empíricos no Capítulo 4. Primeiramente expõem-se os proveitos relativos às regras e procedimentos, ou alterações institucionais do processo decisório de vetos, oferecendo-se, em seguida, os dados que mensuram a não decisão, uma das bases para a concepção de obsolescência. Segue-se a Conclusão, apontando os proveitos e percalços do roteiro empreendido, a verificação das hipóteses, e as sugestões para estudos futuros.

Alguns resultados quantitativos obtidos são apresentados em Apêndice ao texto, incluindo dados sobre as sessões conjuntas em que se pautaram vetos, bem como sobre os vetos presidenciais, contrastando, na medida da pertinência, as informações com as expectativas de ocorrência encontradas na bibliografia de base, notadamente em Moya (2005). Busca-se oferecer uma descrição, ou inventário, dos 1.160 vetos apostos de 1988 a 2014, bem como do exercício de agenda decisória do Legislativo na expressão da decisão sobre vetos, nas 263 sessões conjuntas realizadas com esse objetivo, atendendo a demandas como a de Lamounier (2005, p.66), ao apontar a necessidade de informações básicas sobre os vetos brasileiros em um único banco de dados.

A leitura dos dados foi enriquecida com a experiência profissional do autor, obtida no exercício de cargo efetivo em secretaria afeta às atividades relativas ao processamento dos vetos, bem como ao preparo e assessoramento das sessões conjuntas. A experiência obtida com a coordenação dessas atividades, bem como com a troca de experiências dos profissionais da área, contribuíram com a capacidade de aquisição e leitura da documentação pesquisada, influenciando, em conjunto com o levantamento do percurso histórico, o conjunto de assunções que formaram os pressupostos iniciais, os quais se quer testar com apoio nos dados. 


\section{1 - REVISÃO BIBLIOGRÁFICA E BASE TEÓRICA}

Embora o foco do presente estudo seja a ação do Legislativo no processo decisório de veto, empregou-se a tradição dos estudos da relação Executivo-Legislativo, notadamente em razão de o processo referente ao veto ser compartilhado formalmente entre esses atores institucionais. A ciência política pátria acerca do tema apresenta basicamente três tendências (Palermo 2000): a primeira é reflexo do pressuposto inicial de ingovernabilidade, depois de estabelecida a ordem de 1988, exposto por Abranches (1988), que seria consequência da engenharia constitucional da redemocratização, herdada das tradições republicanas (heterogeneidade regional, multipartidarismo proporcional e presidencialismo imperial), e desconectada da ordem social daquele momento histórico.

A segunda tendência é marcada pela constatação da superioridade do Executivo sobre o Legislativo, na formação de políticas públicas por meio de leis (SARTORI,1996), expressa em um aparato constitucional robusto do presidente da República, capaz não só de ditar a agenda do Legislativo, como também de paralisar sua capacidade decisória. Nessa dinâmica, restaria abalado o status institucional do Parlamento, e ameaçada tanto a sua funcionalidade quanto a da própria democracia, em prol da governabilidade.

Uma terceira tendência parece sintetizar as duas anteriores, admitindo um sistema em que a articulação dos dois poderes resulta em um aglomerado decisório em que o papel diretivo repousa sobre os ombros presidenciais, mas cuja dependência do Legislativo para governar por meio de leis atesta a necessidade permanente de consenso. A essa última filia-se o presente estudo. Como apontado por Lamounier (2005), para o caso do veto, em vez de se falar em sujeição, domínio, devem-se apontar as estratégias recíprocas que reforçam a funcionalidade das instituições políticas brasileiras, na busca por sua estabilidade e produtividade. Em vez de se falar em agenda imposta, há que se perceber a agenda compartilhada (SANTOS, 1997).

Para além da percepção da existência dessa agenda compartilhada busca-se evidenciar o exercício concreto do poder a ela vinculado, no âmbito do Legislativo, na arena específica do veto, percebendo-se os dois poderes como componentes do mesmo processo decisório, mas com pesos supostamente diversos, em um aglomerado decisório com fusão de funções. 


\subsection{Base teórica: institucionalismo da escolha racional}

Conforme Cameron (2000) a teoria da escolha racional é formada por 3 assunções básicas e um conjunto de ferramentas para a construção de modelos. As assunções são: 1) a do ator: o comportamento do ator explica o fenômeno; 2) a da intenção: esse comportamento é intencional, ou racional; e 3) o da agregação: resulta da interação entre atores racionais (intencionados). As ferramentas são: 1) teoria da utilidade (da decisão), uma psicologia dos tomadores de decisão e 2) teoria dos jogos, em uma concepção que formaliza o processo decisório político em modelos matemáticos.

O autor filia-se a um institucionalismo baseado no paradigma expresso no tripé estruturacomportamento-desempenho. Trata-se de compreender os fenômenos por meio da compreensão da instituição (estrutura), seus efeitos sobre a conduta dos atores (comportamento) e as consequências desse conjunto para os resultados das instituições (desempenho). No caso em estudo, tratar-se-ia de descrever as instituições envolvidas no processo decisório do veto, os reflexos dessas instituições sobre o comportamento dos agentes de decisão, individuais e coletivos, e, por fim, o efeito prático dessa interação, que é a formação da lei, veiculadora das políticas públicas e modificadora do status quo. Tal descrição permitirá analisar a evolução do instituto do veto no sistema político pátrio.

A metodologia proposta por Cameron (2000), nesse desiderato, baseia-se em modelos explicativos capazes de revelar os vínculos entre os três elementos. Para tanto, o autor propõe dois passos: o primeiro é o uso da teoria dos jogos não cooperativos para construir modelos; e o segundo passo é aportar evidências empíricas. Embora não se tenha valido dos modelos derivados da teoria dos jogos, o presente estudo preocupou-se em manter essa estrutura analítica como referencial, aplicando-a à descrição dos dados, agregados por legislatura, que é agente coletivo cujo comportamento se observa.

O institucionalismo da escolha racional, notadamente o norte-americano, parece sofrer forte influência dos modelos matemáticos e da teoria dos jogos. Convive-se com termos tais como barganha, estratégia, movimentos, bem como estudos crescem em número e qualidade, privilegiando a análise de comportamentos induzidos pelas instituições. Procurou-se lançar mão 
desse ferramental terminológico, das valências heurísticas da teoria dos jogos, tendo em vista a influência dessa realidade epistemológica. Cameron (2000) chega a pugnar por uma ciência política que se utilize mais amplamente dos modelos disponibilizados pela teoria da firma.

Mas a teoria dos jogos visa essencialmente oferecer soluções para os modelos. Ela não se satisfaz apenas em elaborar os modelos matemáticos da ação coletiva, mas principalmente tratar dos eventos futuros de mesma configuração com uma solução antecipada das situações. Grohmann (2003) foi quem tentou fazê-lo para o veto brasileiro, mas essa não tem sido a regra geral para a ciência política brasileira.

A título de reflexão, à parte a questão do domínio do aparato metodológico considerou-se que a aplicação da teoria dos jogos, com desenvolvimento de modelos espaciais, talvez não trouxesse os melhores resultados. Isso porque se considera que o “jogo total” do veto, ou seja, aquele que leva em conta todo o processo decisório, da aprovação pelo Congresso até a efetiva apreciação do veto, teria de levar em conta o fato de que não se decide sobre o veto de modo regular, nem conforme as regras estabelecidas, o que obriga o analista a prever modelos em que a informação é sempre incerta sobre a ação do Legislativo depois que o Presidente age sobre os projetos aprovados. A legislação brasileira a partir de 1988 foi produzida a partir de um conjunto de arenas que tem como componente o veto não apreciado, uma arena deserta, bem como de um contexto de constantes alterações nas regras e procedimentos vinculados à fase de veto.

Tsebelis (1998) concorda com a constatação de limitação explicativa da teoria dos jogos. O autor identifica dois tipos de jogos ocultos, as múltiplas arenas e o projeto institucional, o primeiro relacionado a jogos múltiplos em que o ator se envolve (arena eleitoral, cargos no Executivo, bases eleitorais e votações de vetos, por exemplo); o segundo, o projeto institucional, são aqueles em que os atores-chave envolvem-se em jogos relacionados às próprias regras do jogo (como é o caso de alterações de regras e procedimentos. Tsebelis denomina “jogo gigantesco” esse conjunto imenso de fatores, aqui denominado “jogo total”, cuja compreensão não se pretende alcançar integralmente.

É inegável o poder explicativo de um bom modelo espacial, e a relevância das aplicações estatísticas de última geração. Procurou-se balancear, entretanto, o potencial explicativo deste estudo quanto aos seus aspectos teóricos e empíricos. Dedica-se a oferecer um modelo descritivo 
que evidencie as escolhas institucionais concretas, em um processo decisório específico, cuja marca maior é o não decidir, ou melhor, o decidir de modo anômalo, contrário ao escopo institucional previamente estabelecido - as regras do jogo - e com consequências para o instituto do veto e para o sistema que ele integra.

Tem-se, pelo exposto, que se opta pelo institucionalismo da escolha racional como base teórica, especificamente o da teoria da decisão, utilizando o ferramental terminológico da teoria dos jogos, apropriado para o objeto de estudo. Defende-se a concepção de que as instituições importam, embora não se responda nos estritos termos da pergunta formulada por Rockam e Weaver (1993), cuja preocupação era o funcionamento dos governos, a finalidade do Estado, ou o desempenho (CAMERON, 2000). Estuda-se a racionalidade dos atores políticos nas decisões, bem como as ferramentas empregadas no processo, com o desiderato da melhor compreensão do processo decisório do veto, e seus resultados.

A racionalidade que se teve em mente, base do institucionalismo da escolha racional, é o pressuposto onipresente de racionalidade dos atores, justificativa de suas ações e da opção humana por instituições. Como sugerido por Cameron (2000) a racionalidade inerente dos atores não é uma condição para uma boa teorização, bastando para tanto a aparência de racionalidade em padrões que possam ser apreendidos pelo cientista em reduções razoáveis. A opção por institucionalizar os processos que se repetem revela um padrão de racionalidade que se expressão tanto na criação quanto no uso das instituições (SHEPSLE, 1997).

O presente estudo satisfaz-se com a racionalidade pressuposta, mas pode-se afirmar ir além da pressuposição, uma vez que considera serem traduções de racionalidade as soluções encontradas pelos atores diante das situações reais de decisão. Essas soluções manifestam-se tanto em comportamentos voltados para resultados imediatos, quanto por comportamentos voltados para resultados duradouros, por meio da institucionalização de regras, reduzindo custos e riscos. É uma racionalidade suficiente para a construção de boas teorizações.

Não houve análise de comportamentos individuais. Mesmo quando os atores foram referidos individualmente, como os presidentes da República e Senado, e líderes partidários, o foram a partir de sua posição institucional. Isso quer dizer que, em uma avaliação exacerbada, tratar-se-ia de análise sem atores, própria das análises sistêmicas, estruturalistas ou funcionalistas 
(TSEBELIS, 1998, p. 34). Assim não o é, porque o enfoque escolhido considera a racionalidade pressuposta, extraída da criação e emprego das instituições, segundo a agregação do comportamento. Todos os atores considerados no presente estudo são institucionais, ocupam funções criadas pela própria Constituição, mas somente a ação racional dos indivíduos dentro dessas estruturas permite derivarem-se conclusões.

Esclareça-se, ainda, que sendo o ator observado um corpo coletivo, a legislatura, procurou-se observar o fenômeno tanto pelo processo decisório formalmente desenhado, quanto pelas regras procedimentais forjadas pelas legislaturas que se sucederam. Consideram-se igualmente relevantes os resultados do agir coletivo, e da ação individualizada, praticada por determinados atores controladores da agenda, responsáveis pelas principais decisões no processo. As reduções analíticas, fatais em qualquer ciência, operaram a consideração do ente coletivo como agente único, ainda que tenha deixado no devido relevo o agir especificamente individual de atores com poder de agenda e veto, na medida da exigência da argumentação que se expende.

\subsection{Poder de Agenda}

Segundo a formulação de Abranches (1988), o presidencialismo de coalizão insere a agenda em seu terceiro momento de formação. O primeiro e o segundo seriam, respectivamente, a aliança eleitoral e a constituição do governo ou formação do gabinete. Trata-se de agenda "real de políticas, positiva e substantiva, e das condições de sua implementação” (ABRANCHES, 1988). O autor considera a transição do segundo para o terceiro momento como o ponto crítico para a manutenção da coalizão formada. Em outras palavras, o aspecto mais sensível para o presidencialismo de coalizão, no que tange a relação Executivo-Legislativo, seria a formação de um “calendário negociado de eventos” (ABRANCHES, p. 28): a agenda concreta.

A agenda substantiva é a combinação do conjunto das políticas públicas que determinado grupo político eleito pretende implementar. Em um contexto institucional de democracia baseada no direito escrito, essa implementação passa necessariamente, em maior ou menor grau, pela formação da lei. Essa substância tem de adentrar, portanto, um local de decisão legislativo, o que 
no caso de sistemas como o brasileiro significa que aquelas intenções de agenda passarão por um filtro onde nem tudo poderá ser decidido, tanto sob o aspecto do conteúdo quanto do momento e do modo de decidir. A capacidade de dispor sobre esses elementos é o que se denomina poder de agenda, envolve tanto a agenda substantiva quanto a agenda concreta.

A centralidade do poder de agenda é conclusão generalizada na literatura (AMORIM NETO;TAFNER, 2002; FIGUEIREDO;LIMONGI, 2001, 2009; BRAGA, 2011; GOMES, 2011; e MARTINS, 2011, como exemplos). Santos (1997) reconhece a função primordial desempenhada pelo poder de agenda ao analisar-lhe a relevância, de modo conjunto com a análise da patronagem, para explicar as diferenças entre o regime constitucional atual, pós 1988, e o anterior, 1946-1964. Para o autor, agenda e patronagem são estratégias comuns de controle nos dois períodos históricos. Além disso, conclui haver a marca da imposição na agenda resultante do processo decisório delineado pela Constituição de 1988 (BRASIL, 1988).

O autor vê nesse poder de agenda a explicação para a funcionalidade do processo legislativo, em vista da fragmentação partidária, causada pelo sistema eleitoral proporcional de lista aberta com distritos de grande magnitude, de viés personalista, e das coalizões compulsórias na formação de maioria governativa. A orientação forçada de preferências, por intermédio de uma agenda legislativa imposta, seria a forma encontrada para contornar essa dificuldade.

Para Figueiredo e Limongi, poder de agenda é “a capacidade de determinar que propostas serão consideradas pelo Congresso” e “quando o serão” (2001, p. 23). Trata-se de poder estrutural (COX; McCUBBINS, 1993.), visto que ordena o conteúdo e o tempo das decisões. A agenda é formada a partir das vontades das forças formadoras da coalizão, distribuídas nos três poderes, mas sua consecução pragmática dá-se no bojo da decisão legislativa, conforme os ditames dos poderes de agenda ali exercidos.

A definição de Cox e McCubbins (2005) para poder de agenda é a de “[...] habilidade de influenciar o que é votado, quando, e como.” (p.37). Para os autores o poder de agenda carrega a característica de proteção das maiorias, ao procurar manter afastado delas as decisões que ela não quer tomar, estabelecendo vizinhança com o conceito de mobilização de tendência, de 
Schattschneider ${ }^{2}$, tratado na Seção 1.3 .2 a seguir. Ou seja, trata-se do poder manifesto na agenda substantiva (o quê), no calendário (quando) e nas regras e procedimentos (como).

Incluir a negativa em decidir na definição do poder de agenda é incluir, por oposição, a noção de não decisão, na medida em que envolve a consideração dos assuntos que ficarão de fora dos debates. Inclui-se o conceito de segunda face do poder, tratado por Bachrach e Baratz (1962), pertencente à discussão comum entre pluralistas e elitistas ${ }^{3}$ sobre o lócus real do poder na sociedade. A segunda face do poder seria o termo que explica como determinados debates sequer chegam a ocorrer, determinados conflitos são ocultados do olhar geral, e determinadas decisões não são tomadas, em razão de haver a supressão do debate.

Os poderes de agenda, para Cox e McCubins (2005), podem ser positivos ou negativos. Os primeiros dizem respeito ao estabelecimento da agenda. Aquelas capacidades diretamente ligadas à mobilização de tendência e às duas faces do poder, uma vez que tocam diretamente a potência de estabelecer sobre que matérias se tratarão. Os segundos dizem respeito ao que Tsebelis (2009) define como atores de vetos, aqueles atores dos processos decisórios de cuja manifestação depende o processo decisório, o que, conforme a combinação de preferências, pode significar até mesmo não decidir.

Para a teoria dos jogos encontrada em autores como Tsebelis (2009) o poder de agenda relaciona-se com o poder de veto. Se o ator com poder de veto é aquele cujo consenso é necessário para que a decisão seja tomada, o estabelecedor agenda é o ator com poder de veto que é o primeiro a se mover. A distância entre atores com poder de veto, em termos de preferência, provocaria instabilidade decisória, pois reduziria o conjunto das decisões efetivas possíveis, cabendo ao estabelecedor de agenda, portanto, a função de somente trazer a debates as matérias sobre as quais o consenso fosse possível, em face dos riscos e interesses envolvidos.

Para Rasch (2014), a abordagem de Tsebelis centra-se no conceito de estabelecimento da agenda. Para que um ator de veto seja determinante em um dado processo decisório, é preciso que o seu poder de propor, de iniciar o jogo, não seja partilhado com outros atores de veto. Isso

${ }^{2}$ A definição de mobilização de tendência leva em conta que toda forma de organização política tem uma "tendência” em favor da exploração de algumas formas de conflito e a supressão de outras, pois a organização é a mobilização da tendência, e tendência é o movimento dos espaços decisórios.

${ }^{3}$ Teorias de democracia em disputa sobre o argumento essencial de participação e poder. 
porque quanto mais atores de veto com preferências incertas, menos espaço existirá para um consenso, que Tsebelis (2009) denomina winset (conjunto vencedor). Esse é o argumento que justifica a centralização decisória comum no processo legislativo brasileiro, como é o caso do veto, cujo poder de agenda respectivo repousa sobre os ombros do Presidente do Senado Federal.

Os atores com o poder de estabelecer a agenda tornam-se automaticamente atores de veto em relação às pretensões das outras partes. Assim se dá com o veto presidencial, quando o Presidente da República estabelece, com a base institucional da Constituição (BRASIL, 1988), a agenda forçada de pauta, em 30 dias, cumulada com o sobrestamento da pauta das sessões conjuntas. O Congresso, de sua ponta, decide quando e como esse processo decisório será concluído, na figura do Presidente do Senado Federal, mas, fá-lo-á com base na extensão e razões de agir do Executivo, expressas na mensagem presidencial que encaminha o veto, e em um tempo premido pela urgência constitucional.

Como já se explanou, agenda é tempo e conteúdo, o que traduz a noção de curso de ação concreta distribuída no tempo, e indica exercício efetivo do poder de decidir. Em linguagem de rotina no Legislativo, a agenda concreta é expressa como: horários de reuniões de colegiados e plenários; designação de pauta de comissão, ou de ordem do dia do plenário, entre outros; quanto ao conteúdo são as matérias, assuntos contidos nas iniciativas de legislação com relação à mudança do status quo. Não se pode deixar de incluir também o modo de decidir, as regras e procedimentos. O poder de agenda é a capacidade, mais ou menos livre, de dispor sobre esses elementos.

As regras e procedimentos dos processos decisórios legislativos constituem uma das bases institucionais do estabelecimento da agenda, conforme descreve Rasch (2014). O autor elege quatro categorias relevantes dessas bases: a habilidade de apresentar assuntos (poder de agenda positivo), a de estabelecer um calendário, a de bloquear mudanças nas políticas (poder de agenda negativo), e a de estabelecer a sequência e ordenar as opções (sequenciar) no estágio final do processo decisório.

No que tange o processo decisório de veto, considera-se que a compreensão de seus detalhes pode contribuir para a compreensão da dimensão concreta do poder de agenda, ao tornar 
possível divisar quem elege o assunto, o tempo (quando) e as regras (como), além de possibilitar a análise do efeito desse estado de coisas sobre as instituições.

Para o caso das sessões conjuntas, em que se reúnem deputados e senadores, sob uma única presidência, destaca-se, além dos líderes partidários, a figura do Presidente do Senado Federal, que ocupa a função de Presidente do Congresso Nacional. Entre outras competências, cabe a ele convocar a sessão conjunta, cenário em que se delibera sobre o veto.

Aplicando-se a lógica da preocupação de Abranches (1988) quanto à formação da agenda de eventos, depois da formação do gabinete de governo, quando a legislação passaria a expressar a maioria governativa representada pela coalizão, surge a necessidade de se distinguir entre agenda substantiva e a agenda concreta, expressão das decisões a serem tomadas. A agenda substantiva somente pode se tornar agenda concreta mediante atuação de seus controladores, agentes em regra institucionais, bem como dos atores com poder de veto (TSEBELIS, 2009), desejados ou não.

\subsubsection{A Agenda do Executivo}

Eleito o Presidente da República, estabelece-se a coalizão governativa do gabinete e, tendo em vista a predominância institucional do Presidente da República brasileiro na formação das leis, resta compreender de que forma essa predominância é traduzida na arena legislativa. Mostra-se necessário, portanto, compreender a agenda substantiva do Executivo.

Andrew Rudalevige (2002) esmiúça as mensagens presidenciais ao Congresso dos Estados Unidos, procurando evidenciar a crescente relevância desses mecanismos para a captação das intenções substantivas do Executivo, no que tange a formação de uma agenda legislativa propriamente dita. Seu objetivo é analisar as tendências de centralização decisória do Presidente da República na formulação da agenda legislativa, ou melhor, a agenda governamental veiculada por lei. 
Essa abordagem parece ser útil para o caso brasileiro, dado que se consolidou, a partir da Constituição de 1988 (BRASIL, 1988) uma formatação da apresentação dos planos de governo ao Congresso e à sociedade. Vencida a fase eleitoral, a agenda substantiva do Presidente brasileiro se inicia com o discurso de posse e entrega ao Congresso da Mensagem Presidencial, no início de cada ano legislativo e, por fim, consolida-se no sistema de planejamento e orçamento, consubstanciado nas leis do plano plurianual, nas quatro leis de diretrizes orçamentárias, e nas respectivas leis orçamentárias anuais, além da legislação não orçamentaria.

Pode-se considerar como agenda substantiva presidencial aquela contida nos programas de Governo. A oscilação desses programas, conforme expressa também Diniz (2005) é, em maior ou menor grau, contingente e conjuntural. É mais ou menos fixa, portanto. Essa mutabilidade depende tanto de fatores exógenos: macroeconomia e relações internacionais, quanto de fatores endógenos: problemas de coalizão e de procedimentos. Apesar desse caráter mutável, trata-se de um ponto de partida razoável para o estudo da agenda substantiva do Executivo.

Figueiredo e Limongi (2009) preferem o termo “agenda da maioria” ao termo "agenda do Executivo”, o que parece apontar a evolução dessa terminologia, que passou a levar em conta os resultados positivos alcançados pelas coalizões presidenciais formadas no período democrático corrente, em face de uma configuração institucional a princípio improdutiva. Os autores apontam dois mecanismos centrais para a imposição da agenda da maioria: a urgência constitucional e a medida provisória. O veto inserir-se-ia nessa realidade, mais notadamente o veto parcial, por haver com ele a alteração do status quo da parte promulgada do projeto, somando-se a isso o trancamento de pauta depois de 30 dias de tramitação, o que confere certo feitio de urgência na tramitação.

Note-se que a agenda da maioria não coincide sempre com a agenda da coalizão, o que pode ocorrer tanto em governos chamados minoritários, quanto em governos com boas coalizões, mas com baixa disciplina, resultando igualmente em uma maioria contrária às pretensões governativas presidenciais. A agenda das maiorias em um lapso específico de quatro anos, correspondente ao mandato de presidente da República e a dois mandatos de presidentes do Congresso, seria, por outro lado, a agenda da Legislatura. 
Como já dito, a agenda substantiva é veiculada pela lei, todos os planos plurianuais, as diretrizes e metas governamentais e as leis orçamentárias com eventuais alterações posteriores são autorizadas pela lei, passam pelo crivo dos acordos políticos, e do processo decisório formal do Congresso. O regime de conteúdos precisa ser submetido também a um regime de tempos, visto que para decidir é preciso fazer escolhas, e o tempo não é suficiente para estender a decisão de modo indefinido.

A definição dessa agenda substantiva, e a compreensão do exercício presidencial do poder de agenda situam-se entre as principais preocupações da ciência política pátria. Interessa, porém, compreender um aspecto específico desse sistema, qual seja, como se forma a agenda concreta do Congresso nas decisões relativas ao veto aposto pelo Presidente da República, visto que o poder de agenda do Executivo, pelo que restou explicado, não sobrevive sem a aquiescência dos que detêm o poder de agenda no Legislativo, ainda que prepondere fortemente sobre a agenda substantiva do Legislativo.

\subsubsection{A Agenda do Legislativo}

A agenda do Executivo é formada pelo conjunto de intenções elencadas, de modo expresso ou não, em programas de governo. Ela interfere efetivamente na agenda do Legislativo, quando ocorre a iniciativa, quer seja com a edição de medida provisória, com a mensagem de pedido de regime de urgência a matérias de sua autoria, e com a iniciativa formal de projeto de lei, além das iniciativas indiretas que impactam o texto das matérias em tramitação, por meio da inclusão de emendas de autoria da base de governo, notadamente dos líderes do governo nas duas Casas legislativas.

A iniciativa presidencial induz a cooperação, transformando a agenda legislativa. Braga (2011) também situa o exercício do poder de agenda no conteúdo e no momento. Perdido o momento, ou o conteúdo, transformada está a agenda. A distribuição temporal que se opera é a dos conteúdos, ou matérias. Sendo assim, na medida em que o Congresso interrompe o regime temporal estabelecido para o veto, reduz a força dessa indução sobre a agenda. 
Sob o aspecto temporal, a escolha do momento de exercer a iniciativa, combinada ao emprego de dispositivos de abreviação da tramitação ditam o ritmo da agenda. Como assinala Santos (1997), “o direito de requerer urgência para seus projetos, por sua vez, confere ao presidente recurso de enorme valor em se tratando da atividade parlamentar: tempo.” (p. 472 negritos nossos).

Ricci (2003), por sua vez, oferece uma explicação sobre o conteúdo da legislação, reconhecendo a interferência da variável tempo, e concluindo que o tempo decisório é um dos fatores levados em conta pelos parlamentares ao proporem ou defenderem determinada legislação, independentemente dos interesses que atendem, sejam paroquiais ou gerais.

Isso ocorre porque a agenda legislativa concreta é uma só, no sentido de que o tempo e o espaço são limitados para decidir. Isso quer dizer que o Congresso não poderia votar todas as matérias que pretende, mesmo que não houvesse nenhuma interferência do Executivo. Mas a agenda do Legislativo é também a agenda das maiorias, controlada pelos líderes e presidentes das Casas (FIGUEIREDO;LIMONGI, 2009), o que varia conforme as características de cada coalizão, podendo resultar não em uma apenas, mas em várias agendas, nem sempre consensuais.

Amorim Neto, Cox e McCubbins (2003) chegam a identificar, especificamente na Câmara dos Deputados, os “cartéis de agenda”, aglomerados de veto players (atores com poder de veto), formados pelos agentes da centralização decisória do Legislativo, que são capazes de se apropriar dos locais de controle as regras de decisão, exercendo e oportunizando o veto em cada situação. Consideram que onde haja governo de coalizão deverá haver cartel ou cartéis de agenda. Essa abordagem reforça a agenda como recurso valoroso nas mãos dos atores políticos.

Considera-se, portanto, poder de agenda concreto a faculdade de que dispõe o Poder Legislativo de, por meio de seus principais atores, escolher sobre o que decidir, como e quando fazê-lo. A partir de sua concepção como ator político, animado pelos princípios que conformam sua razão de existência, o Poder Legislativo disporá de poder de agenda concreto sempre que os atores responsáveis por ela alcançarem o efeito de escolha do momento de agir e das regras dessa ação, independentemente do conteúdo (a agenda substantiva).

Para o processo decisório de veto, destacam-se como atores de agenda os Presidentes da República e o do Senado Federal (os fluxos das Figuras 11 e 12 ilustram a centralidade desses 
atores no processo decisório formal do veto). O primeiro no que tange sua já bastante estudada capacidade de estabelecedor da agenda, iniciador preferencial do processo legislativo e agente praticante do veto. As competências do segundo estão estabelecidas principalmente nos regimentos internos das Casas $^{4}$ e garantem um agente dotado de amplas competências que abrangem a tramitação das matérias legislativas, as comissões, a ação dos líderes partidários, poderes específicos de agenda, que incluem as convocações e a condução das sessões plenárias, aplicação e interpretação das normas internas, poderes disciplinares e de indicação, além dos poderes administrativos, com responsabilidades sobre robustos orçamentos (VIEIRA, 2011).

O Presidente do Senado responde pelas principais ações relativas aos vetos. A convocação de sessão conjunta ocorre segundo comando regimental segundo o qual basta comunicar ao presidente da Câmara dos Deputados (BRASIL, 1970, art. $2^{\circ}$ ), sem previsão de qualquer consulta a colégios de líderes. Somem-se a essa competência aquelas relativas à interpretação dos três regimentos, com aplicação dos institutos normativos internos conforme sua autoridade, com ressalva das questões de ordem sobre as quais ele decide. Sendo assim, sempre que houver referência a poder de agenda concreto no presente estudo, estar-se-á a falar, basicamente, do Presidente do Senado Federal, principalmente no que tange as convocações de sessões conjuntas e a batuta sobre as alterações em regras e procedimentos.

Przeworski (1984) aponta que na democracia “[o] o poder é transferido de um grupo de pessoas para um conjunto de regras” (p.38), tamanha pode ser a dimensão do conceito das instituições estruturantes do processo decisório legislativo. Compreender a agenda é, portanto, compreender o aspecto mais importante do processo legislativo, onde se localizam comportamentos mediante regras, bem como regras a ditar comportamentos, tendo o tempo como recurso escasso e os inevitáveis efeitos das decisões sobre o sistema político e seus institutos.

Pelos aspectos discutidos, elegeram-se como fenômenos de interesse para a compreensão do poder de agenda do Legislativo as regras e alterações procedimentais na apreciação de vetos e a não decisão do Congresso sobre eles. A análise desses dois fenômenos auxilia no aclaramento

\footnotetext{
${ }^{4}$ Aplicam-se às sessões conjuntas as regras do Regimento Comum e, subsidiariamente os Regimentos do Senado e da Câmara (nessa ordem).
} 
do conceito de poder de agenda concreto do Legislativo, bem como fomenta a discussão em torno da obsolescência ou decadência do veto.

\subsection{Não Decisão}

Como se verá no Capítulo 2, por mais exitosas que possam ser as regras e procedimentos aplicados ao longo das sete legislaturas em estudo, permanece o déficit deliberativo sobre os vetos. A presente seção relaciona poder de agenda e obsolescência do veto, ao tratar do mencionado fenômeno da não decisão congressual. Embora possa ser vista tão somente como inércia, ou conduta inconstitucional, considera-se proveitoso analisá-la sob o ponto de vista de sua concepção como poder de agenda concreto. Para tanto se tratará de dois aspectos: o processo legislativo do veto como processo decisório e a interpretação teórica do fenômeno. Já os dados sobre o período estudado serão analisados no Capítulo 4.

\subsubsection{Processo legislativo do veto como processo decisório}

Como já afirmado, o processo do veto é parte formal do processo decisório da lei, a qual por sua vez é a fase legislativa de tomada de decisão na formação de políticas públicas (INÁCIO, MENEGUIM, 2014). Como consequência, o processo do veto é parte do processo de formação da lei, mas somente é determinante quando altera resultado do processo legislativo ordinário, algo que, para o recorte temporal observado, não se verifica, de modo que se estaria diante de processo decisório inconcluso.

Para a teoria constitucionalista do processo legislativo (SILVA, 2006) (FERREIRA FILHO, 2002), a formação da lei ocorre em três fases: introdutória, constitutiva e complementar. O veto presidencial insere-se na fase constitutiva (Figura 10), o que o torna, para o Direito, um ato jurídico complexo, somente aperfeiçoado pelo concurso de duas vontades concordantes. Mas, apesar do que repete o senso comum, não se trata exatamente de uma vontade coletiva oposta a 
uma vontade singular. Trata-se da vontade final de dois órgãos marcados pela coletividade, cada qual conforme seu desenho institucional (PEREIRA, 2014), e ambos vocacionados à centralização decisória.

Figura 1: Processo Decisório Legislativo da lei ordinária

Fase Introdutória - Iniciativa

Faculdade restrita a atores previstos na Constituição Federal

\begin{tabular}{|c|c|}
\hline \multicolumn{2}{|c|}{$\downarrow$} \\
\hline \multicolumn{2}{|c|}{ Fase Constitutiva - Deliberação } \\
\hline $\begin{array}{c}\text { Deliberação Legislativa } \\
\text { Discussão - Votação }\end{array}$ & $\begin{array}{c}\text { Deliberação Executiva } \\
\text { Sanção - Veto }\end{array}$ \\
\hline \multicolumn{2}{|c|}{$\downarrow$} \\
Fase Complementar \\
Promulgação e Publicação \\
\hline
\end{tabular}

Fonte: Pereira, 2014, com base em Silva (2006)

Para expressar o processo decisório do veto, sob o aspecto formal institucional, Pereira (2014) elabora fluxos de decisão para cada um dos dois poderes envolvidos no processo (ver Fluxos das Figuras 11 e 12). O escopo institucional inclui basicamente a Constituição Federal, de 5 de outubro de 1988 (BRASIL, 1988); o Decreto n 4.176, de 28 de março de 2002 (BRASIL, 2002); e o Regimento Comum (BRASIL, 1970). Conforme conclusão do autor, a estrutura decisória formalmente traduzida desse escopo é singela, e pouco revela sobre o processo decisório do veto. Mas dois elementos dos fluxos merecem análises mais aprofundadas: as instituições informais e o fator tempo. 
10 dias. $\S 1^{\circ}$ art. 52, Dec. 4.176/02

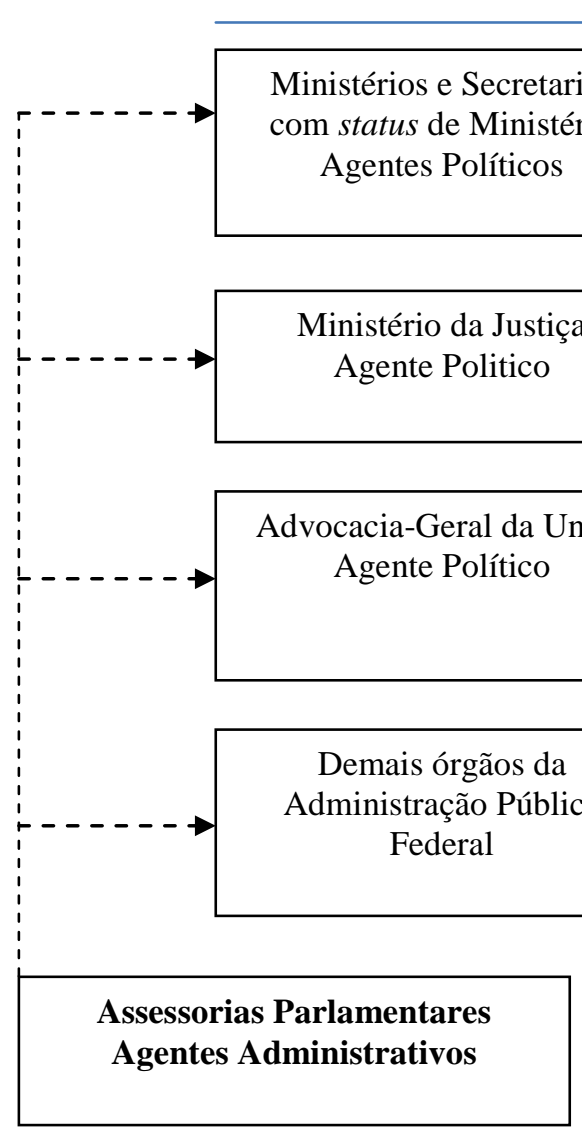

Fonte Pereira, 2014

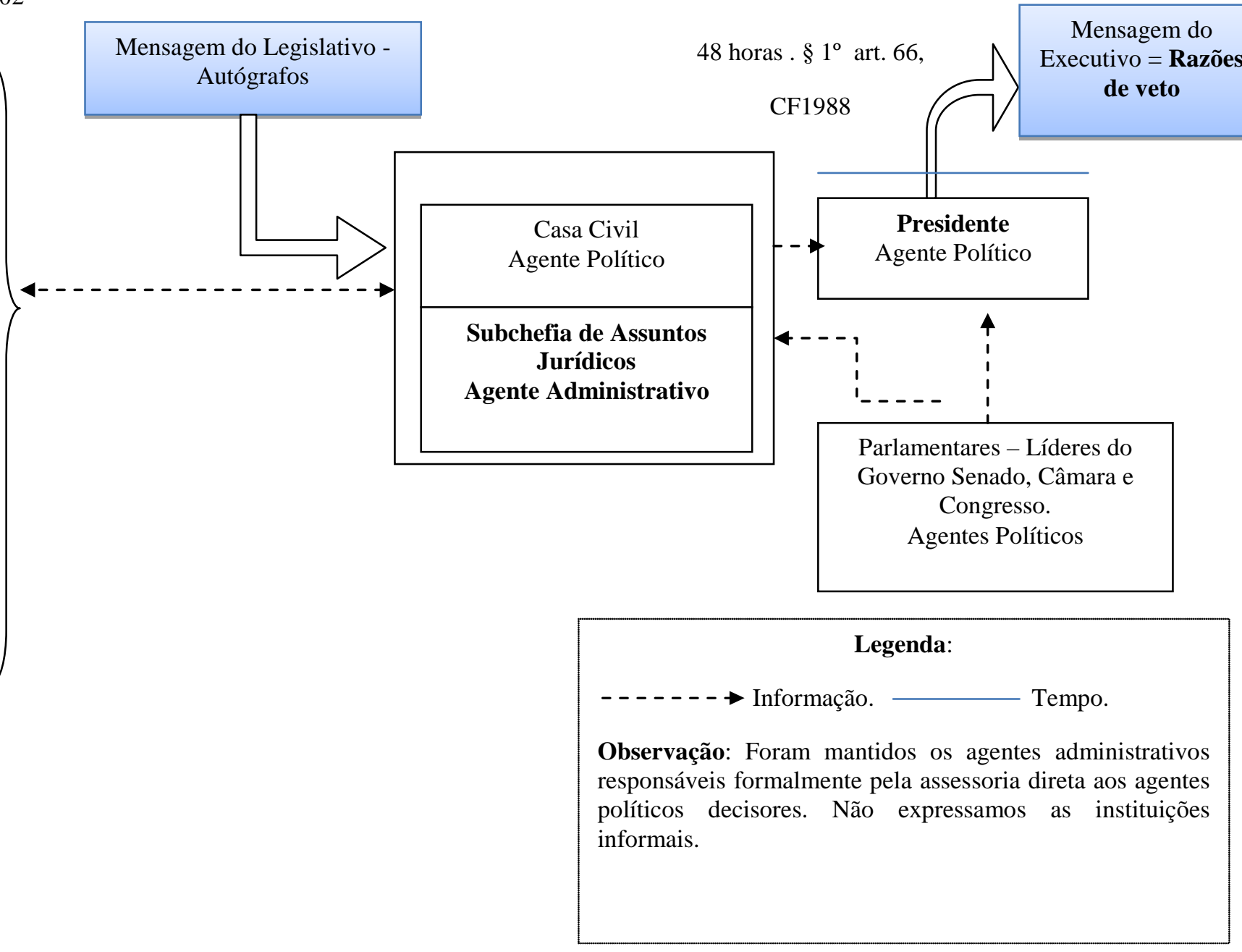


30 dias $\S 4^{\circ}$ art. 66,

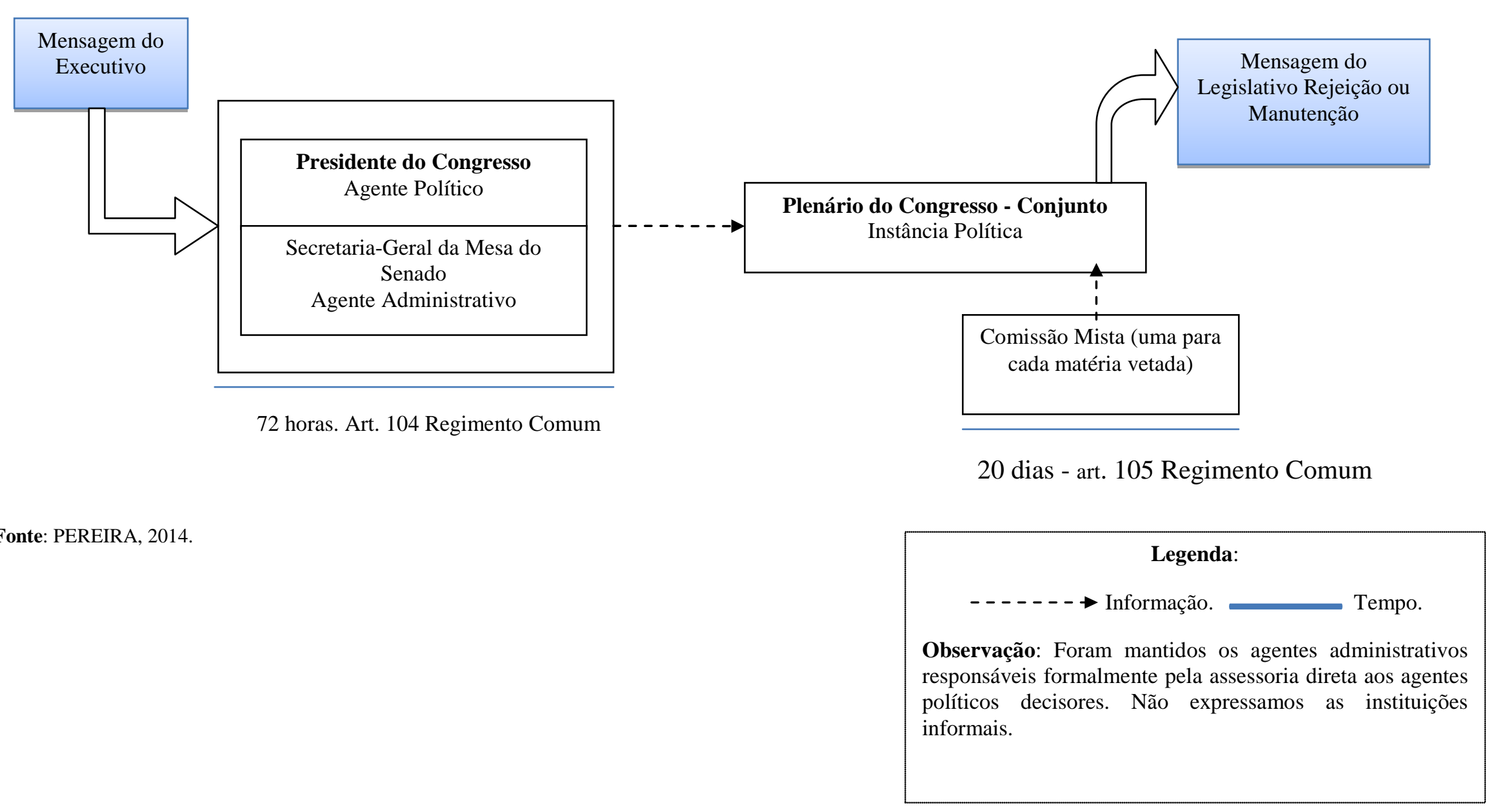


Conforme contribuições de Helmke e Levitsky (2003), as instituições informais trazem à tona a complexa discussão acerca das “(...) regras compartilhadas socialmente, normalmente não escritas, que são criadas, transmitidas e aplicadas fora dos canais sancionados oficialmente” (p.8). Seriam aquelas regras, seus respectivos seguidores e sancionadores, que não são dadas a conhecer facilmente, pois não se encontram inscritas nos anais das Casas legislativas, e tampouco estão expressas na maior parte da documentação de pesquisa, incluindo-se leis, regimentos, diários, etc. As instituições desse processo decisório não compõem o escopo deste estudo, mas poder-se-ia considerar a não decisão como uma instituição informal, dado seu caráter de permanência e reforço, conforme se mensura na próxima seção.

Grohmann (2003) e Lamounier (2005) empregam a categoria dos “jogos ocultos” de Tsebelis (1998), para expressar outro fenômeno relativo à compreensão da dimensão informal do processo decisório do veto. Grohmann o faz para superar o chamado paradoxo do veto, que é a impossibilidade lógica de sua ocorrência para o jogo do veto como jogo de informação completa, em um contexto de múltiplas arenas. A dinâmica dos jogos ocultos seria sustentada pelo "apoio mútuo”, expressão cunhada pelo autor para expressar as trocas não evidentes, efetuadas entre os jogadores. Lamounier (2005) conclui de modo similar a Grohmann (2003), com sua definição de 'reciprocidade estratégica', dinâmica que seria orientada pelos jogos ocultos, em que os ganhos estariam distribuídos em instâncias diversas, relacionadas ao governo em si, bem como à manutenção dos parlamentares nos cargos e interesses diversos.

Eis porque é necessário reconhecer que a simplicidade dos fluxos formais, reduções dos processos decisórios sobre o veto, esconde uma gama considerável de instituições postas em uso no processo decisório do veto. Um modelo simplificado tenderá a deixar de fora todas as possíveis arenas, ou cenários de jogos ocultos (nested games, no original em inglês), quer seja singelo, quer sejam sofisticados, como as formalizações espaciais da teoria dos jogos (GROHMANN, 2003). Processos decisórios como o do veto estão marcados pela convivência entre o formal e o informal.

O fator tempo é o segundo elemento dos fluxos interessante para análises futuras. Trata-se de uma categoria central para o estudo dos processos decisórios políticos. Como já mencionado, o processo decisório político é altamente adaptável às explicações formais das teorias dos jogos e 
o tempo de agir é determinante em qualquer jogo. Os movimentos dos jogadores devem levar em conta o tempo de ação dos demais jogadores.

A filosofia do direito oferece uma reflexão pertinente. Ost (2005), ao tratar da relação entre tempo e direito, lembra que, ao longo da História, o Estado vai de liberal, passando pelo de mudança social, chegando ao atual Estado-propulsor. Para Ost, entramos na era do "efêmero eterno” (p. 327), em que “[...] mais que a moderação e a duração, é a aceleração e a urgência que caracterizam o tempo político [...]” (p.334). Esse sentimento permeia os atuais Estados democráticos de direito, dá o tom dos processos decisórios governamentais e atinge o processo legislativo. É uma noção que “[...] transforma qualquer prazo em prorrogação insuportável e qualquer tramitação em um bloqueio institucional criticável.” (p. 334-335).

O tempo oprime tanto o Executivo quanto o Legislativo. Este, no entanto, como se sabe, padece particularmente de uma avaliação contemporânea que o tem como moroso e atrasado em face das demandas sociais. O atual Estado-propulsor (CASAGRANDE, FREITAS FILHO, 2010) demanda uma temporalidade diversa daquela própria das decisões discutidas em detalhes, tratadas à exaustão. O argumento do tempo é elemento transversal de grande parte das discussões sobre a atuação do legislativo. Aparece com força total na análise das escolhas perpetradas pelo constituinte de 1988 (BITTENCOURT, 2012), tendo como uma de suas consequências a escolha não apenas do presidencialismo, mas de um presidencialismo imperial, em que o grande acelerador legiferante é o Presidente da República.

Grohmann (2003) e Lamounier (2005) fazem coro com essa voz corrente de que os governos dos Estados atuais são forçados a darem respostas cada vez mais rápidas às demandas sociais, o que justificaria a concepção do processo legislativo como quase incompatível com essa exigência contemporânea. Pessanha (1997) registra a relevância do fator tempo para explicar a tradição de transferência do poder de legislar ao Executivo, que remontaria à Revolução Francesa, passando pelos períodos da I e II Guerras, sendo um fenômeno registrado também na Inglaterra.

No caso do veto, a partir de seu efetivo uso, ocorre um momento crítico do processo decisório legislativo, que é a necessidade de formação de uma nova maioria para considerá-lo. O papel central decisório retorna ao Legislativo. A exigência de se obter uma nova maioria das duas 
Casas reinaugura os processos de negociação e barganha, estabelecidos na fase constitutiva da matéria vetada, que pode ter levado muitos meses, mesmo em matérias em regime de urgência. Com a prática reiterada, os legisladores tendem a considerar o processo como concluído, e embora tecnicamente não o seja, ainda que contra a Constituição, ele já se concluiu politicamente.

Além disso, no caso dos vetos parciais, que representam quase 70\% do total, o status quo já sofre modificações, pois não há efeito suspensivo, e a parte sancionada é imediatamente promulgada, ou seja, o tempo já corre contra o Parlamento, cuja agenda diária não cessa de ver chegar novas demandas. O tempo oprime os estabelecedores de agenda, que fazem suas escolhas aparentemente conscientes de suas possibilidades temporais concretas.

Os riscos de se promover um retorno à matéria lançam o legislador em um cenário de nova incerteza, diante do qual lhe restam três alternativas: manter o veto, rejeitá-lo ou, ainda, não decidir, embora essa seja expressamente contrária ao texto constitucional. O segundo esforço deliberativo não tem ocorrido, e a alternativa selecionada tem resultado em um permanente déficit deliberativo.

Nessa linha, não decidir seria a intenção de deixar a matéria “esfriar”, quer seja por interesse da maioria, ou da coalizão, quer seja para afastar a matéria vetada do proscênio pelo tempo necessário ao seu esfriamento, tendo em vista a possibilidade de permanecer deliberando de modo reativo ao processo “iniciado” pelo Executivo. Nesse contexto, o poder reativo do Presidente da República quando exercido significa, no jogo do veto, que a reação passa a ser devida ao Legislativo.

Ao mesmo tempo, não decidir gera a expectativa de não ameaça as preferências do Executivo. Se a tendência do presidente, em um contexto em que se delibera sobre vetos, seria a de pensar duas vezes antes de vetar, já em um contexto de reiterada inércia, ele ganha um movimento certo no jogo, e fica mais à vontade para vetar, porque suas perdas potenciais vão se tornando reduzidas.

De acordo com Limongi (2006), o presidente tende a evitar o envio ao Congresso de itens de sua agenda em que se anteveja derrota. A segunda face do poder presidencial, nesses casos, é expressa pela decisão de formar sua agenda de iniciativas conforme a viabilidade no cenário 
legislativo, em obediência a uma lei de antecipação de reações, própria da teoria dos jogos. Essa combinação resulta em um cenário de conflitos reduzidos, ou tornados latentes.

Embora os estudos atuais já deem conta da alternativa da não decisão, ou rejeição política (FERREIRA JÚNIOR; PERLIN; ROCHA, 2012), posta à disposição daqueles que detêm o poder da decisão legislativa, permanece a necessidade de mensurar e explicar sua ocorrência. Para o período em análise, a saída inconstitucional foi regra, operou-se a referida não decisão.

\subsubsection{Significados da não decisão}

Uma das explicações para o fenômeno encontra-se nos trabalhos de Bachrach e Baratz (1962), sobre o que os autores denominam “duas faces do poder”. Uma face seria expressa pela forma de distribuição do poder entre aqueles que iniciam ou finalizam os processos decisórios

relevantes em uma dada comunidade. A segunda face do poder é menos visível, e expressar-se-ia pela distribuição do poder entre os que cumprem o papel instrumental de manutenção dos assuntos perigosos fora da arena decisória.

Os autores empregam o conceito de decisão de Dahl, que é “o conjunto de ações que incluem e dizem respeito à escolha de uma alternativa em vez de outra” (1962, p.639) (tradução nossa). Tratam especificamente da decisão em cenário de exercício de poder, em que as relações em jogo envolvem ações de um indivíduo para com outro, no intuito de decidir, ou seja, ações decisórias políticas. A não decisão seria o outro lado dessa moeda. As situações de não decisão existem sempre que uma das alternativas da decisão trouxer efeitos negativos, e que não houver disposição para lidar com esses efeitos por parte dos formuladores e controladores da agenda.

O conceito de não decisão de Bachrach e Baratz associa-se ao conceito de "mobilização de tendência”, de Schattschneider (1957), o qual remete a uma discussão mais ampla da ciência política, inserida na disputa entre os teóricos pluralistas e os elitistas no que se refere à origem do poder nas decisões coletivas das democracias. 
Schattschneider identifica que “toda forma de organização política tem uma 'tendência' em favor da exploração de algumas formas de conflito e da supressão de outras, pois a organização é a mobilização da tendência” (1957, p. 936) (tradução nossa). A escolha do conflito aloca poder, e essa alocação tem relação direta com a forma de organizar a decisão, ou seja, com os atores e instituições decisórias. O processo de não decisão seria, assim, o impacto da mobilização das tendências sobre assuntos latentes cuja emergência se quer evitar, uma forma de poder de agenda negativo, conforme conceituação da Seção 1.2.

O fenômeno da “rejeição política”, identificada por Ferreira Júnior; Perlin; Rocha (2012) seria uma expressão desse mecanismo, operacionalizado quando o momento de decidir não é o mais adequado para quem detém poder de decidir, aqueles que controlam a agenda. Com intuito de alcançar uma maior compreensão do processo legislativo, os autores empregam o método do process tracing para compreender a tramitação de um dos projetos de lei que tentaram promover a reforma política, o PL n 1.270 de 2007 (BRASIL, 2007). Chegaram a duas conclusões interessantes.

A primeira diz respeito à dicotomia forma-conteúdo. O PL 1.270 teve sua origem material - do conteúdo - no Projeto de Lei n ${ }^{0} 2.679$ de 2003, o que atesta uma característica verificada para diversos outros fenômenos do processo legislativo observados pela ciência política: o estudo das formas nem sempre, por si só, é suficiente para se apreender o conjunto dos fatores que cercam uma decisão legislativa política. Não basta saber sob que nome típico seguiu um processo, algo obtido pelo process tracing, mas também apreender as alternativas criadas pelos atores com poder para tal, para contornar limitações processuais e a alcançar o consenso.

Essa conclusão é particularmente útil para o processo decisório de veto como parte do processo decisório da lei. Não rejeitar o veto não quer dizer sempre concordar com ele, mas, dada a conjuntura, mantê-lo ou nem decidir sobre ele pode ser mais proveitoso, tendo em vista que outras arenas podem acolher o conteúdo vetado em determinado projeto, e lograr aprovação inclusive do próprio presidente da República.

A segunda conclusão útil diz respeito ao conceito de rejeição política. Segundo os autores, a parte do PL 1.270 submetida a votos no Plenário foi tão somente aquela para qual já havia consenso, controlado pelos Líderes partidários. O consenso por acordo político do grupo menor 
de líderes precedeu à tomada de votos em plenário, a qual seria o processo decisório legislativo por excelência. A parte consensual foi votada em plenário, conforme orientação das lideranças ao microfone, e a parte sem consenso sequer foi votada, sofrendo "rejeição política”, fenômeno que se caracteriza pela negativa da maioria em declarar sua decisão, apoiada pelo argumento do dissenso.

O argumento do custo político da rejeição política reforça a presente linha de argumentação. Os controladores de agenda e os atores de vetos, de acordo com as circunstâncias, podem decidir não decidir, tendo em vista as consequências da decisão, e as não consequências de não decidir. Os incentivos para deixar de agir podem superar os custos, o que parece ser devido tanto à ausência da sanção quanto à ameaça de danos ao fazê-lo. As explicações preliminares envolvem, portanto, dois argumentos: restrições temporais e custo político de fugir do conflito. Não são excludentes entre si, já que são inegáveis tanto as dificuldades de decidir sobre todas as matérias de interesse em tempo limitado, quanto as vantagens de se eliminar um campo de conflito em uma relação interinstitucional.

Já sob o ponto de vista jurídico, mais especificamente sob a ótica do direito constitucional, o comportamento do Congresso no que tange os vetos pode ser visto como costume constitucional (BULOS, 1996), que é um dos possíveis agentes do processo de mutação constitucional. O autor inclui os usos e costumes na prática constitucional, a exemplo do que a teoria jurídica já faz com os costumes jurídicos secundum, praeter e contra legem.

A prática constitucional, exercida por meio dos usos e costumes, é expressão do poder constituinte difuso (BULOS, 1996; FERRAZ, 1986), poder de mutação cujo titular é o Legislativo. Para os juristas, no entanto, o limite para esse poder, em constituições rígidas, seria o próprio texto constitucional. Sendo assim, o costume constitucional contrário ao texto, ou contra constitutionem, não seria possível. Mas ocorre. A prática constitucional contra legem deveria existir apenas para suprir lacunas ou esclarecer obscuridades textuais, mas no caso estudado, a desobediência ao texto operou como escape para a agenda do Legislativo. O dever ser, próprio da literatura jurídica, nega a validade da mutação constitucional com essa natureza. Embora a prática de não decisão sobre vetos não substitua o texto da Carta Magna, é forçoso admitir que a prática existe e caracteriza o período estudado, a experiência histórica constituiu essa interpretação do texto constitucional, contra ele, com ou sem a teoria jurídica. 
Embora os acordos firmados para tramitação de vetos em uma legislatura não obriguem a próxima, viu-se que as soluções exitosas e convenientes de um tempo foram sendo ratificadas ao longo dos anos, como ocorreu com a cédula. Criada para atender a uma emergência, converteu-se num mecanismo facilitador da legitimação do processo decisório atípico, em que o processo legislativo juridicamente construído funcionou apenas como inspiração.

Outro efeito jurídico da decisão intempestiva diz respeito à segurança jurídica. Veto não apreciado é processo legislativo suspenso. Uma vez que a tramitação só pode ser solucionada por meio de sessão conjunta - não havendo possibilidade expressa de arquivamento por término da legislatura - o veto não apreciado configura uma possibilidade indefinida de conclusão de processos legislativos.

Os 229 vetos que permanecem em tramitação no final de 2014, apresentam um tempo de tramitação médio de 1.447 dias, ou quase 4 anos. É razoável supor que a rejeição de vetos depois desse tempo representa uma considerável ameaça às relações jurídicas estabelecidas.

Cita-se o caso da possiblidade de apreciação conjunta de 205 vetos, desdobrados em 3.060 dispositivos, em 19 de dezembro de 2012 (BRASIL, 2012a), em sessão que não se realizou, convocada com o fito de "limpar" a pauta de vetos, e oportunizar a votação do veto dos royalties. Decisão do Ministro Luiz Fux, do Supremo Tribunal Federal (STF) (BRASIL, 2012b), impedira que o veto mais atual fosse apreciado antes de todos os mais antigos. Diante dessa possibilidade, o Advogado-Geral da União, Luiz Adams, em manifestação encaminhada ao STF, informava ao Supremo o risco econômico existente na apreciação de tantos vetos depois de tanto tempo.

O Advogado-Geral argumentou haver imensos riscos para a segurança jurídica e fiscal do país a rejeição dos vetos pendentes de apreciação. A título de ilustração, a rejeição de apenas um deles, o Veto $n^{0}$ 11, de 2010 (BRASIL, 2010), cuja matéria vetada tratava do reconhecimento do direito ao crédito tributário do crédito prêmio do IPI, se rejeitado, causaria um impacto aproximado de 280 bilhões de reais. Os números totais atingiam cifras na casa dos trilhões.

O que até aqui se construiu corrobora a hipótese de que o veto apreciado pelo Legislativo de 1988 a 2014 não se presta a auxiliar a compreensão dos conflitos entre Executivo e Legislativo, porque se trata de arena de conflitos deserta, processo decisório incompleto, marcado 
pela não decisão. Mesmo as rejeições de vetos, como se viu, não podem ser consideradas todas elas episódios em que o conflito seja a razão necessária de ocorrência, ou mesmo se prestaria a auxiliar na compreensão da alegada superioridade do Executivo.

Argumenta-se que o poder de agenda do Congresso, no processo decisório de veto, tem como principais expressões concretas as regras e procedimentos bem como o reiterado não decidir; e como principal agente o PMDB na presidência do Congresso Nacional. Com as mudanças procedimentais o Legislativo buscou demonstrar esforço em lidar com a agenda forçada, mas com a predominância do não decidir causou a formação de estoques, que foram demandando mais inovações procedimentais para combater um crescente passivo deliberativo, além do efeito concreto de manter intocadas as decisões do Executivo sobre a legislação em vigor, confirmando um veto que não corresponde mais a sua prescrição normativa, nem indica mais o sistema de separação dos poderes esperado pela teoria.

\subsection{Estudos Recentes}

A literatura nacional sobre o veto, tanto como instituto jurídico quanto como instituição política, não é farta. Como instituto, há esforços de sistematização teórica, como os de Baracho (1984), além dos clássicos teóricos (CASASANTA, 1937; BRITTO, 1966; RODRIGUES, 1993; ALECRIM, 2008). Para o estudo do veto como poder político, destacam-se os recentes trabalhos de Grohmann (2003), Lamounier (2005) e Moya (2005).

Grohmann (2003), tendo por norte a estabilidade do regime democrático brasileiro, expresso na relação entre os poderes Legislativo e Executivo, investiga o poder de veto nos seus aspectos descritivos, submetendo-os a trato estatístico, correlacionando variáveis para obter explicações úteis sobre a solução do jogo do veto, comparando dois períodos (1946-1964 e 19902000). Emprega, portanto um recurso metodológico raramente utilizado pela ciência política brasileira (SANTOS, 2008), que são os modelos espaciais e a teoria dos jogos. Suas principais conclusões são: 
a) o fortalecimento do instituto do veto pelo aumento do quórum de 2/3 dos presentes à sessão de deliberação (1946-1964) para maioria absoluta dos membros das Casas (1990-2000), com mais vetos apostos e menos casos de rejeição de vetos; e b) relacionamento entre as variáveis disciplina partidária, tamanho da coalizão e quantidades de vetos e derrubadas, para afirmar que a variável independente é a disciplina, a partir da qual se preveem as demais, de modo que, quanto maior a disciplina, menor a maioria mínima a ser controlada pelo Executivo, com consequente aumento na quantidade de vetos, portanto. O oposto disso seriam coalizões muito grandes e inseguras, o que reduziria o número de vetos.

O estudo abrange um lapso temporal total de 29 anos, sendo 19 referentes ao período 1946-1964 (cerca de cinco legislaturas) e dez referentes a 1990-2000 (cerca de duas legislaturas e meia), recorte temporal superior ao que vem sendo analisando atualmente (SANTOS, 2008). O estudo compara, assim, dois períodos distintos da História do Brasil, agregando os dados utilizados por coalizão, e analisando apenas os vetos totais.

Empregando a terminologia da teoria dos jogos, Grohmann (2003) detecta no jogo de veto brasileiro, os chamados ‘jogos ocultos', nos termos de Tsebelis (1998) ${ }^{5}$, fenômeno exógeno que diz respeito a decisões aparentemente irracionais dos jogadores políticos. Fortalece, assim, a interpretação da teoria política atual, de comportamento variado dos congressistas, tendo em vista as múltiplas arenas a que paralelamente comparecem: eleitoral, legislativa e executiva, para citar as três mais comuns. O autor infere também o valor interferente de um fenômeno endógeno: a instituição informal do logrolling (ou troca de votos, que o autor denomina “apoio mútuo”).

Ao tratar da variável quórum, Grohmann cunha o termo “espiral de comparecimento” para os casos em que é necessário, em curto espaço de tempo, conseguir parlamentares para formarem quóruns de maioria para as diversas votações.

Lamounier (2005), tendo por norte a indagação sobre o uso intenso de veto, mesmo já contando o Presidente com vários outros instrumentos de controle da agenda, propõe-se a obter um modelo explicativo capaz de alinhavar os elementos descritivos das variáveis observadas

${ }^{5} \mathrm{O}$ conceito abrange as situações em que se observam atores considerados racionais fazendo escolhas que não são as melhores, em razão de não se terem levado em conta, na observação, jogos não explícitos, que ocorrem quando há outras arenas de jogo, ou quando se inovam regras e instituições para alargar a base de atuação de determinados jogadores. 
(maioria, iniciativa presidencial, tipos de projetos, emendas parlamentares e vetos), relevantes para a definição do poder de agenda, empregando o método da análise de trajetória. Traz as seguintes contribuições:

a) quanto maior o tamanho da coalizão (maioria governativa), maior é o número de medidas provisórias e de iniciativa ordinária presidencial, e menor o número de vetos; b) emendas alterando projetos de iniciativa do Presidente da República sofrem mais vetos; e c) a orientação partidária e a posição na coalizão interferem na aposição de vetos.

O estudo abrange 13 anos, referentes ao período 1989-2002 (cerca de três legislaturas), com dados agregados mês a mês, pela metodologia da regressão estatística, associada ao emprego de variáveis qualitativas (dummies). Lamounier aponta cinco diferenças entre seu estudo e o de Grohmann (2003): 1 - universo amostral maior, ao incluir vetos não apreciados e lapso temporal maior (apesar de Grohmann abranger mais legislaturas como exposto); 2 - acréscimo dos vetos parciais; 3 - estabelece relações entre iniciativa presidencial e vetos; 4 - a dimensão do jogo de veto é maior, ao incluir vetos ainda não apreciados na análise; e 5 - inclusão das razões de veto (consideradas por Grohmann como causas explícitas do veto, mas não incluídas em sua análise empírica).

Lamounier (2005), com base em Olivetti (1998), distingue procedimento legislativo (interno, relativo às regras próprias na formação da lei) de processo legislativo (externo, incluindo outros aspectos relacionados), para atestar a relevância de compreender o segundo. Assim como Grohmann (2003), reconhece a importância explicativa das trocas mútuas para o processo de veto, adotando igualmente o conceito de jogos ocultos de Tsebelis (1998). O autor chama a atenção também para o tema dos projetos, na medida em que atribui relevância às suas variáveis de autoria e tipo, na determinação da relevância do assunto tratado, com reflexos sobre as possibilidades de veto.

O autor conclui, com base na apreciação feita sobre as alterações parlamentares não vetadas, independentemente da iniciativa, haver protagonismo do Legislativo. Conclui haver um movimento articulado entre os poderes na produção da agenda, o qual denomina 'reciprocidade estratégica’ (LAMOUNIER, 2005, p. 187). 
Lamounier (2005) investiga o veto na condição de variável dependente. Analisa, portanto, a Presidência e não o Legislativo propriamente. Sua preocupação é a ocorrência do veto, em face de suas indagações acerca do exercício do poder de veto como evento interessante para explicar as relações entre os dois poderes em contexto de presidencialismo de coalizão. Embora se preocupe inicialmente com a questão da importância institucional do Legislativo, analisa a atuação do Executivo pela predominância deste em contexto de estratégia recíproca com aquele.

Inicia a análise pelo delineamento teórico do presidencialismo caracterizando-o, como a ciência política tradicional, pela separação equilibrada entre os poderes. Como conceito de democracia elege o de Przeworski, de democracia procedimental, em que preponderam os elementos de incerteza e competição entre os atores políticos com interesses divergentes. Ou seja, um conceito para o qual o resultado do modelo democrático é consequência das instituições decisórias que o conformam.

Esse caminho leva o autor a analisar a configuração institucional pátria atual como sendo consequência do momento histórico de concepção de uma constituição que assegurasse eficiência ao Poder Executivo, em face de demandas sociais urgentes. Um dos efeitos negativos imediatos dessa configuração institucional teria sido o enfraquecimento do Legislativo diante de um Executivo que acumularia poderes de agenda e de veto.

O autor desenvolve o raciocínio de que o Legislativo seria menos livre que o Executivo, operando em um ambiente fortemente regrado. A partir desta assunção ele trabalha com as categorias distintas de procedimento legislativo e processo legislativo, sendo o último mais amplo que o segundo. Isto para introduzir o já referido conceito de jogos ocultos de Tsebelis (1998).

Moya (2005) também se ocupa do aspecto da produção do veto. Admitindo como pressupostos o processo legislativo e seus atores, em ambos os ramos de poder, o autor elege variáveis para prever a ocorrência do veto, concluindo serem mais determinantes as características individuais do projeto do que as externalidades. Desenvolve para sua explicação três modelos: um geral, outro no qual aplica variáveis uma a uma, e um terceiro modelo em que as variáveis são combinadas.

Tendo por norte a indagação acerca da elevada ocorrência de vetos, ainda que o Presidente da República disponha de forte poder de agenda para aprovar matérias de sua 
preferência, o autor apresenta diversos resultados para comprovar a maior relevância dos fatores endógenos ao processo legislativo em comparação com os fatores exógenos:

a) os vetos parciais são mais difíceis de prever que os totais; b) projetos com temas sociais são menos vetados; c) tamanho da coalizão tem efeitos sobre o número de vetos parciais, mas não de vetos totais; d) o maior tamanho da coalizão seguido do maior número de vetos totais não quer dizer que essa coalizão seja confiável; e) ao contrário de Lamounier (2005), para ele as medidas provisórias não sofrem menos vetos; f) projetos de partidos da oposição sofrem mais vetos totais; g) por meio de dois indicadores de relevância - urgência e votação nominal -, revela-se uma menor incidência de vetos totais, combinando ou separando os indicadores; h) ocorrem menos vetos totais nos últimos seis meses do mandato do presidente; i) para o período avaliado, o Presidente que mais recorreu ao veto foi José Sarney; e j) elevada frequência de vetos totais sobre projetos de iniciativa do Legislativo, atingindo cerca de $50 \%$ de todos os projetos enviados à sanção.

Moya propõe-se a avaliar simultaneamente um conjunto de mais de vinte variáveis independentes, por meio da metodologia de elaboração de modelos multivariados de regressão logística, utilizando um software próprio (SPSS 10.0.), com testes de pós-estimativa, aplicada ao projeto aprovado como unidade de análise.

As variáveis foram divididas em endógenas (poder de origem, tipo de proposta, tema, emendamento, o regime de urgência, modalidade votação, importância, e tempo de tramitação) e exógenas (tamanho das coalizões, disciplina das coalizões, o presidente que apôs o veto, popularidade presidencial, partido do autor, autoria da oposição, região do autor, projetos apresentados e vetados por presidentes diferentes, calendário eleitoral, e a época do mandato quando do veto).

O estudo abrange 12 anos (cerca de três legislaturas), mas propõe-se a analisar um corpus maior de dados, totalizando 1.322 projetos aprovados no período. O autor apresenta como pressupostos o fato de o veto ser parte do processo legislativo e de que ambos os poderes, Legislativo e Executivo, são atores determinantes nesse processo, de onde conclui que fatores exógenos e endógenos podem causar o veto, com prevalência dos segundos. 
Moya (2005) conclui no mesmo sentido de grande parte da literatura que o poder Executivo brasileiro conta com o veto contra os valores que o criaram, quais sejam, a separação dos poderes, o sistema de freios e contrapesos e o equilíbrio decisório na formação da lei. Reforça a conclusão de prevalência do Executivo, o que corrobora sua indagação inicial. Isso não causa surpresa, uma vez que da análise das prerrogativas presidenciais constitucionais já se pode vislumbrar essa predominância. Moya (2005) soma-se à literatura existente que afirma que essa predominância traduz uma superioridade.

Essas três teses oferecem contribuições para a compreensão da instituição da Presidência. A base teórica é o presidencialismo de coalizão e as trocas interinstitucionais na legiferância governativa. Cameron (2000) estuda a presidência dos Estados Unidos, produzindo também uma contribuição teórica sobre a instituição da presidência.

Vistas e consideradas as contribuições dessas referências, objetiva-se contribuir com uma teorização do Legislativo, razão pela qual as reflexões nem sempre estiveram diretamente centradas na relação Executivo-Legislativo, ou no Presidente da República, sendo foco o Congresso Nacional brasileiro, seu comportamento sobre o decidir político representado por um instituto juspolítico relevante para a compreensão do processo legislativo. Pode-se considerar que se trata de uma complementação da observação do fenômeno, direcionada para o comportamento do Legislativo.

Para tanto, procede no Capítulo seguinte, a um sobrevoo histórico do veto, de sua origem mais remota até o momento de sua mais recente formatação constitucional, para então descrever as alterações institucionais de regras e procedimentos, legislatura a legislatura. 


\section{2 - EVOLUÇÃO HISTÓRICA, REGRAS E PROCEDIMENTOS}

A origem do veto, em primeira análise, é a da própria faculdade de dizer não, de impedir. A evolução do instituto perpassa diferentes regimes e contextos históricos, conservando, entretanto, uma característica essencial: a potência de interrupção de uma vontade política pela oposição negativa de outra, estando ambas em disputa pela consecução do poder de modificar o status quo por meio da lei escrita.

Rodrigues (1993) situa o surgimento do poder de veto, em sentido próprio, na préhistórica civilização hitita, onde a prerrogativa do veto era conferida a uma assembleia aristocrática (pankus), capaz de se opor às decisões do rei. Tratava-se, de certo modo, de uma defesa de forças aristocráticas, mais coletivas, contra o poder real, monocrático e legislador.

Essa conformação transmitiu-se à Grécia, de dois modos diferentes. Na assembleia popular ateniense, que, embora não tivesse direito a voto, tinha direito a manifestar-se negativamente, impedindo decisões do rei que a contrariassem. E em Esparta, um conselho de anciões (gerúsia) detinha o poder de vetar os projetos de lei da assembleia popular (apela) (BRITTO, 1966). Já se percebe aqui, um fenômeno que Britto (1966) denomina transposição do poder de veto, que seria a tendência histórica da mudança de sua titularidade das assembleias populares às aristocracias e aos reis, por razões que se verificarão a seguir.

Em Roma surge o instituto de intercessio. Este era o poder conferido aos tribunos da plebe de se oporem às decisões políticas da aristocracia do senado e da magistratura. Britto (1966) assinala que aqui, novamente, o senado, com o auctoritas, adquiriu o poder de controle sobre o veto da plebe (um veto legislativo no sentido contemporâneo), anulando a força do veto dos tribunos. O tribunato fora um direito de representação adquirido pela plebe ao longo de incessantes conflitos com os patrícios por igualdade, que culminaram com a retirada daquela para o Monte Sagrado, onde se pretendia criar outra cidade. Ao longo da história romana, oscilando sempre entre aristocracia e democracia, já no fim do império, o veto foi se tornando um direito pessoal singular, repousando sobre os ombros dos suseranos e as coroas dos reis (CASASANTA, 1937; BRITTO, 1966). 
O verbo latino veto, flexão em primeira pessoa do verbo vetare, com tradução possível de “eu me oponho”, era a fórmula utilizada pelos tribunos da plebe romana quando do exercício do poder de intercessio. Essa forma permaneceu até os nossos dias, apesar da evidente transformação histórica de sujeitos e objetos, de Roma até o Brasil. Sua marca mais evidente é a de poder reativo contra o poder de estatuir, como uma forma de resistência.

Mason (1891) explica que, quando da invasão da Inglaterra pelos povos germânicos, não se falava em veto, e o poder de fazer leis era dos comuns, do povo. Em razão das vicissitudes da representação, advindas da expansão territorial do domínio inglês, o poder dos reis cresceu, na medida em que os corpos legislativos deixaram de exercer a função de legislar, sustentando tão somente o direito formal. O resultado é que os reis passaram a legislar. Tal poder só foi devolvido aos comuns, após longo processo histórico, com o Act of Parliament, de 1766, que deixou para o rei tão somente a possibilidade de veto absoluto. A partir de então o veto real foi se tornado cada vez mais raro, até seu completo desaparecimento (o último ocorreu em 1907). Moya (2005) atribui esse desaparecimento ao radicalismo do caráter absoluto do veto, e consequente desgaste advindo do confronto entre os poderes. As negociações em torno da formação da lei ganharam outros locais, como a alteração do projeto antes de seu envio ao rei.

O veto absoluto inglês existia nos treze estados coloniais dos Estados Unidos. Era exercido sob forte influência da metrópole e mal visto pela maioria dos presentes à convenção constitucional da Filadélfia, em 1776. Na verdade, os americanos sequer admitiam um Executivo Federal centralizado em um presidente. Depois da independência, vários estados chegaram a ser governados por corpos colegiados, ou comissões. Mas foi admitida pela convenção a necessidade dessa figura, argumento que alavancou e fez vingar consigo o instituto do veto na constituição dos Estados Unidos de 1787. Seu texto foi copiado do artigo respectivo da constituição do estado de Massachussetts. Nessa transposição de continentes e sistemas políticos, resta o poder de veto mais uma vez nas mãos de um só homem, o Presidente da República, “descendente direto dos monarcas” (BRITTO, 1966, p. 12).

Uma distinção relevante se faz, no entanto, entre o poder de veto da metrópole e o da colônia livre: o surgimento do veto suspensivo. Para que o instituto do veto pudesse ser admitido pela maioria dos representantes dos estados da Convenção da Filadélfia, foi proposta a previsão de sua rejeição, por dois terços de cada uma das Casas do Congresso. Aplicadas as lições de 
Montesquieu, a produção da legislação ocorre sob atentos olhos presidenciais e, de quando em vez, somente subsiste depois de reiterada votação. Eis o modelo que influenciou os estados brasileiros já na monarquia, e a Constituição Republicana pátria de 1891. Se na Inglaterra esse poder foi exercido pela via do impedimento, sua evolução atesta o fortalecimento de sua característica de ponto de colaboração, já na convenção da Filadélfia. Casasanta (1937), há quase 80 anos, já apontava que o Executivo não tinha no veto apenas um poder reativo, mas “[...] principalmente o meio de que se serve para cooperar na obra legislativa.” (p. 332).

A possibilidade de superação do veto, bem como a de oferecer um projeto alternativo, próprias do modelo americano, tornaram o veto em um instituto modificado, se levadas em conta as condições e motivos de seu surgimento. A moderação da negativa, que vai se tornando mais e mais reversível, traduz também a necessidade dos sistemas políticos ao longo da história de evitar o confronto interinstitucional representado pelo impasse entre poderes na feitura da lei. O veto republicano nasce com uma tendência de modulação, superação e, no limite, de desaparecimento.

O imperador e os presidentes brasileiros contaram com o poder de veto desde a primeira constituição (1824), tendo sido esta, a imperial, a única de inspiração europeia (CASASANTA, 1937), por influência da Constituição espanhola, jamais tendo sido absoluto, mas sempre suspensivo, passível de superação pelo Legislativo (RODRIGUES, 1981). A partir da proclamação da República, no entanto, todas as constituições brasileiras mantiveram em seu texto a possibilidade de veto, mas nos moldes da constituição dos Estados Unidos da América, estabelecida pela Convenção da Filadélfia em 1787 (GROHMANN, 2003; LAMOUNIER, 2005; MOYA, 2005).

O veto da Constituição de 1988 (BRASIL, 1988), não pertence, portanto, à tradição do veto romano, mas sim àquela da Convenção da Filadélfia, de onde foi copiado. Isso decorre da aplicação do modelo de presidencialismo estadunidense em terras brasileiras. Relevante notar-se outro ponto comum no surgimento do instituto nos dois países: a conjuntura institucional. Moya (2005) menciona que uma das preocupações dos 13 estados americanos reunidos na Filadélfia era a lentidão dos governos no atendimento das necessidades da sociedade. Este mesmo argumento comparece à constituinte de 1988, quando o sistema presidencialista sobrevive mesmo após meses de formação de um texto constitucional preparado para o parlamentarismo. 
Durante o processo histórico de evolução do instituto, particularmente no que tange seu emprego por reis ingleses, o veto manifestou-se como poder residual de um rei que foi sendo afastado de seu poder de legislar. Essa mudança trouxe consigo o medo crescente dos parlamentos e a criação da imagem de um poder legiferante por excelência, diante de um administrador dos negócios do Estado, cumpridor da vontade de uma maioria representada, para quem o poder de veto servia como um escudo protetor, um poder de reação.

Na formação da constituição estadunidense, por exemplo, havia o temor de que o presidente fosse solapado pela pujança do congresso, a quem se atribuía a maior titularidade da soberania popular. Mas o poder de veto concedido ao presidente estadunidense foi o qualificado, ou suspensivo, ou seja, passível de ser superado pelo congresso. Argumentou-se que, assim, terse-ia um instituto menos ofensivo e por isso mesmo mais efetivo. Os argumentos dos federalistas favoráveis ao veto frequentemente abordavam o aspecto de justiça e da boa formação da lei.

No caso brasileiro, no entanto, parece ter havido outro tipo de receio na mente dos que defendiam um presidencialismo (leia-se um presidente) mais forte: a incompetência do Legislativo, traduzida pela lentidão e pela falta de conhecimento especializado em seus processos decisórios (FIGEIREDO;LIMONGI, 2006).

Ao mesmo tempo, o veto parece vir sempre a reboque do argumento presidencialista de compensação da separação estrita de funções entre os poderes. Constant (1872) considerou recomendável que o ramo de poder incumbido de executar as leis não tivesse que ser submetido a leis sem razão ou exequibilidade. Em outras palavras, pondera o pensador francês que, para que operasse a separação das faculdades de confeccionar e executar a lei, deveria existir necessariamente a faculdade de impedir a formação da lei contrária à razão.

Quanto ao caráter de instituto de moderação e colaboração entre os poderes, o veto brasileiro registra uma modalidade que o modifica ainda mais: o veto parcial. Existente desde a reforma constitucional de 1926 à primeira Constituição republicana do Brasil, de 1891 (BRASIL, 1891), o instituto do veto parcial persiste no nosso processo legislativo. Em nossa vida republicana, ele chega a ser mais frequente nos textos constitucionais, na modalidade aberta (qualquer parte do projeto pode ser vetada, mesmo expressões isoladas) do que na restrita 
(somente texto integral do articulado legal, ou seja, artigo, parágrafo, inciso, item, número ou alínea).

A título de síntese, o Quadro 1 apresenta um resumo das principais características do veto em todas as constituições brasileiras, com ênfase nos aspectos relacionados a sua apreciação pelo Legislativo. 
Quadro 1: Regulamentações Constitucionais do Veto no Brasil

\begin{tabular}{|c|c|c|c|c|c|c|c|c|c|}
\hline Ano & Extensão & Razões & $\begin{array}{l}\text { Prazo do } \\
\text { Presidente }\end{array}$ & $\begin{array}{c}\text { Resultado da } \\
\text { não } \\
\text { apreciação } \\
\text { Executivo }\end{array}$ & $\begin{array}{c}\text { Sessão do } \\
\text { Legislativo }\end{array}$ & Quórum & $\begin{array}{c}\text { Prazo do } \\
\text { Legislativo }\end{array}$ & $\begin{array}{l}\text { Sanção à não } \\
\text { apreciação } \\
\text { Legislativo }\end{array}$ & Tipo de voto \\
\hline 1824 & $\begin{array}{l}\text { Total } \\
\text { Suspensivo }\end{array}$ & $\begin{array}{l}\text { Vontade do } \\
\text { Imperador }\end{array}$ & 30 dias & Suspensão & $\begin{array}{l}\text { Não } \\
\text { Especificado }\end{array}$ & $\begin{array}{l}\text { Maioria } \\
\text { Absoluta dos } \\
\text { presentes }\end{array}$ & $\begin{array}{l}\text { Duas } \\
\text { legislaturas }\end{array}$ & $\begin{array}{l}\text { Permanência da } \\
\text { suspensão }\end{array}$ & Aberto \\
\hline 1891 & Total & $\begin{array}{l}\text { Inconstitucionalida } \\
\text { de e Contrariedade } \\
\text { a interesse nacional }\end{array}$ & 10 dias & Sanção Tácita & $\begin{array}{l}\text { Casas } \\
\text { separadas }\end{array}$ & $\begin{array}{ll}2 / 3 & \text { dos } \\
\text { presentes }\end{array}$ & $\begin{array}{l}\text { Não } \\
\text { Especificado }\end{array}$ & $\begin{array}{l}\text { Não } \\
\text { Especificado }\end{array}$ & Aberto \\
\hline 1926 & $\begin{array}{l}\text { Total e } \\
\text { Parcial livre }\end{array}$ & $\begin{array}{l}\text { Inconstitucionalida } \\
\text { de e Contrariedade } \\
\text { a interesse nacional } \\
\end{array}$ & 10 dias & Sanção Tácita & $\begin{array}{l}\text { Casas } \\
\text { separadas }\end{array}$ & $\begin{array}{ll}2 / 3 & \text { dos } \\
\text { presentes } & \end{array}$ & $\begin{array}{l}\text { Não } \\
\text { Especificado }\end{array}$ & $\begin{array}{l}\text { Não } \\
\text { Especificado }\end{array}$ & Aberto \\
\hline 1934 & $\begin{array}{l}\text { Total e } \\
\text { Parcial livre }\end{array}$ & $\begin{array}{l}\text { Inconstitucionalida } \\
\text { de e Contrariedade } \\
\text { a interesse nacional }\end{array}$ & 10 dias & Sanção Tácita & $\begin{array}{l}\text { Somente casa } \\
\text { que originou } \\
\text { projeto }\end{array}$ & $\begin{array}{l}\text { Maioria } \\
\text { absoluta dos } \\
\text { membros }\end{array}$ & 30 dias & $\begin{array}{l}\text { Não } \\
\text { Especificado }\end{array}$ & Secreto \\
\hline 1937 & $\begin{array}{l}\text { Total e } \\
\text { Parcial livre }\end{array}$ & $\begin{array}{l}\text { Inconstitucionalida } \\
\text { de e Contrariedade } \\
\text { a interesse nacional }\end{array}$ & 30 dias & Sanção Tácita & $\begin{array}{l}\text { Casas } \\
\text { separadas }\end{array}$ & $\begin{array}{ll}2 / 3 & \text { dos } \\
\text { presentes }\end{array}$ & $\begin{array}{l}\text { Não } \\
\text { Especificado }\end{array}$ & $\begin{array}{l}\text { Não } \\
\text { Especificado }\end{array}$ & Aberto \\
\hline 1945 & Total & Não Especificado & 30 dias & Sanção Tácita & $\begin{array}{l}\text { Casas } \\
\text { separadas }\end{array}$ & $\begin{array}{|ll|}2 / 3 & \text { dos } \\
\text { presentes } & \\
\end{array}$ & $\begin{array}{l}\text { Não } \\
\text { Especificado }\end{array}$ & $\begin{array}{l}\text { Não } \\
\text { Especificado }\end{array}$ & \begin{tabular}{|l|} 
Não \\
Especificado
\end{tabular} \\
\hline 1946 & $\begin{array}{l}\text { Total e } \\
\text { Parcial livre }\end{array}$ & $\begin{array}{l}\text { Inconstitucionalida } \\
\text { de e Contrariedade } \\
\text { a interesse nacional }\end{array}$ & 10 dias & Sanção Tácita & Conjunta & $\begin{array}{l}2 / 3 \text { dos } \\
\text { presentes }\end{array}$ & $\begin{array}{l}\text { Não } \\
\text { Especificado }\end{array}$ & $\begin{array}{l}\text { Não } \\
\text { Especificado }\end{array}$ & Secreto \\
\hline $\begin{array}{c}1961- \\
1963\end{array}$ & $\begin{array}{l}\text { Total e } \\
\text { Parcial livre }\end{array}$ & Não Especificado & \begin{tabular}{|l|} 
Não \\
Especificad \\
o
\end{tabular} & $\begin{array}{l}\text { Não } \\
\text { Especificado }\end{array}$ & Conjunta & $\begin{array}{ll}3 / 5 & \text { dos } \\
\text { presentes }\end{array}$ & $\begin{array}{l}\text { Não } \\
\text { Especificado }\end{array}$ & $\begin{array}{l}\text { Não } \\
\text { Especificado }\end{array}$ & \begin{tabular}{|l} 
Não \\
Especificado
\end{tabular} \\
\hline 1965 & $\begin{array}{ll}\text { Total } & \text { e } \\
\text { Parcial } & \\
\text { restrito }\end{array}$ & $\begin{array}{l}\text { Inconstitucionalida } \\
\text { de e Contrariedade } \\
\text { a interesse nacional }\end{array}$ & 10 dias & Sanção Tácita & $\begin{array}{l}\text { Não } \\
\text { Especificado }\end{array}$ & $\begin{array}{l}\text { Não } \\
\text { Especificado }\end{array}$ & $\begin{array}{l}\text { Não } \\
\text { Especificado }\end{array}$ & $\begin{array}{l}\text { Não } \\
\text { Especificado }\end{array}$ & \begin{tabular}{|l} 
Não \\
Especificado
\end{tabular} \\
\hline 1967 & $\begin{array}{l}\text { Total e } \\
\text { Parcial livre }\end{array}$ & $\begin{array}{l}\text { Inconstitucionalida } \\
\text { de e Contrariedade } \\
\text { a interesse nacional }\end{array}$ & 15 dias & Sanção Tácita & $\begin{array}{|lr|}\begin{array}{l}\text { Conjunta } \\
\text { voto }\end{array} & \text { com } \\
\text { separado } & \text { em } \\
\end{array}$ & $\begin{array}{l}2 / 3 \text { dos } \\
\text { membros }\end{array}$ & 45 dias & Veto mantido & Aberto \\
\hline
\end{tabular}




\begin{tabular}{|c|c|c|c|c|c|c|c|c|c|}
\hline 1969 & $\begin{array}{l}\text { Total e } \\
\text { Parcial livre }\end{array}$ & \begin{tabular}{|l|} 
Inconstitucionalida \\
de e Contrariedade \\
a interesse nacional \\
\end{tabular} & 15 dias & Sanção Tácita & $\begin{array}{|lr|}\begin{array}{l}\text { Conjunta } \\
\text { voto }\end{array} & \text { com } \\
\text { separado } & \\
\end{array}$ & $\begin{array}{l}2 / 3 \text { dos } \\
\text { membros }\end{array}$ & 45 dias & Veto mantido & Aberto \\
\hline 1988 & $\begin{array}{l}\text { Total } \\
\text { Parcial } \\
\text { Restrito }\end{array}$ & $\begin{array}{l}\text { Inconstitucionalida } \\
\text { de e Contrariedade } \\
\text { a interesse nacional }\end{array}$ & 15 dias & Sanção Tácita & $\begin{array}{lr}\text { Conjunta } & \text { com } \\
\text { voto } & \text { em } \\
\text { separado } & \end{array}$ & $\begin{array}{l}\text { Maioria } \\
\text { absoluta dos } \\
\text { membros }\end{array}$ & 30 dias & $\begin{array}{l}\text { Inclusão } \\
\text { automática em } \\
\text { ordem do dia } \\
\text { com } \\
\text { trancamento de } \\
\text { pauta. }\end{array}$ & $\begin{array}{l}\text { Secreto/Abert } \\
\text { o (EMC } \\
76 / 2013)\end{array}$ \\
\hline
\end{tabular}

Fonte: Grohmann (2003, p. 234, adaptado).

Nota: Veto parcial livre, qualquer palavra ou expressão pode ser vetada; veto parcial restrito, só podem ser vetados, por inteiro, artigos, parágrafos, etc. 
Destacam-se do Quadro 1, pela relevância na linha argumentativa, duas características dessa trajetória histórico-normativa: o veto parcial e o prazo contra o Congresso.

\subsection{O Veto Parcial}

Contam Casasanta (1937) e Alecrim (2008) que o veto parcial surge no sistema constitucional brasileiro na reforma constitucional de 1926 à primeira constituição republicana de 1891. Dentre as primeiras lições aprendidas pelos homens políticos daquele tempo os autores destacam os orçamentos “rabilongos” e a insuficiência do veto total.

Os primeiros dizem respeito a um fenômeno atual, que é a criação de leis com vários temas, com heterogeneidade considerada indesejável entre eles. No caso específico das leis orçamentárias, essa possibilidade mostrou-se, desde o início, apropriada para os parlamentares buscarem o atendimento de interesses individualizados de suas bases eleitorais. Isso porque, curiosamente, as leis orçamentárias não podiam ser rejeitadas pelas casas legislativas, e o veto total ao projeto lançaria os governos em situação de insegurança jurídica, com sérias consequências para a administração dos negócios públicos.

Essa configuração criou, tanto nos Estados Unidos quanto no Brasil, uma situação em que os parlamentos passaram a ser vistos como oportunistas ao incluírem na lei orçamentária toda sorte de emendas estranhas ao seu objeto, e os presidentes da República, por seu turno, passaram a defender o veto parcial como solução para o impasse.

É razoável supor que bastaria um veto constitucional às emendas que fugissem ao objeto orçamentário, assim como seria razoável que essa fosse a regra geral para as leis, orçamentárias ou não. Esse raciocínio foi suficiente nos Estados Unidos, onde, apesar das tentativas, o veto parcial continua sendo visto com maus olhos, e dificilmente é admitido pelos atores políticos ${ }^{6}$.

\footnotetext{
${ }^{6}$ Ver Stearns (1992), para uma discussão atualizada sobre o tema naquele país.
} 
Essa não foi a escolha constitucional do Brasil, onde, conforme se pode ver do Quadro 1, o veto parcial tem sido a regra. No projeto de revisão constitucional de 1926 havia duas emendas: uma para impedir emendas estranhas ao objeto da lei orçamentárias, e outro para incluir o veto parcial no sistema. Entre os que se opunham a ele os argumentos principais eram: excesso de poder concedido ao Presidente, dissolução da unidade do projeto, e concessão de uma forma de emenda supressiva ao Presidente.

Apesar das razões em contrário, as emendas foram aprovadas e, desde então, o veto parcial passou a ser largamente utilizado. O período estudado revela um percentual de vetos parciais que chega a 90\% em matérias de autoria do Presidente da República, e a 60\% nos demais. Se considerado apenas o período posterior a 1994, essa média atinge quase 99\% para projetos de iniciativa do Presidente e 65\% nos demais. Essa proporção consagra a intuição de que o Presidente emprega o veto parcial para ajustar o projeto a suas próprias preferências, dispensado da necessidade de escolher entre quaisquer perdas, em face do comportamento do Legislativo.

Para os Estados Unidos, onde não existe veto parcial, Stearns (1992) argumenta que seu principal efeito não seria sobre a legislação orçamentária, não seria determinante para evitar o chamado pork barrel (distribuição de benefícios orçamentários para as bases eleitorais), mas seria uma importante arma nas mãos do Executivo, a ser utilizada em suas barganhas com o Legislativo. Carey e Shugart (1992) concordam que ocorre ganho de poderes presidenciais com a existência do veto parcial, embora já haja trabalhos que apontam que já não subsiste o principal argumento contrário à existência desse tipo de instituto no modelo americano: o chamado pork barrel (INDRIDASON, 2010).

Para Britto (1966) a previsão de vetos parciais pode significar a flexibilidade necessária para que o Executivo lide com os grupos de pressão. Isso talvez porque o veto parcial permite a transigência nos projetos de interesses corporativos. Somem-se a essa assertiva os dados sobre os vetos rejeitados ${ }^{7}$, e pode-se concluir que o veto parcial, criado sob o argumento da repelência às políticas concentradas em interesses de pequenos grupos, hoje pode operar em favor delas.

\footnotetext{
${ }^{7}$ Ver no item 2.9 do Apêndice a predominância, entre os vetos rejeitados, de vetos totais sobre matérias de interesse de grupos corporativos.
} 
É curioso o deslocamento para o instituto do veto de uma discussão mais ampla sobre a atividade legiferante: o objeto temático da lei. A existência de projetos aprovados contendo mais de um objeto, depois da incorporação de alterações que tratam de temas totalmente diversos do escopo inicial é um problema bastante atual e encontra-se no centro da discussão de disciplinas como a Legística ${ }^{8}$, em que a preocupação central é a qualidade da lei gerada, foco de importantes críticas aos parlamentos contemporâneos.

Entre os argumentos da revisão de 1926, favoráveis ao veto parcial, encontrava-se o de que caberia ao Presidente evitar no projeto as partes destoantes dele mesmo. Em outras palavras, melhorar o texto, por meio do veto às partes incongruentes. A exigência do objeto único está positivada no art. $7^{\circ}$ da Lei Complementar $n^{0}$ 95, de 1998 (BRASIL, 1998). No entanto, é frequente a multiplicidade de objetos, notadamente nos projetos de lei de conversão, oriundos de medidas provisórias. Essa prática tem recebido diversos apanágios como “caudas”, riders, ou o mais atual “jabuti”, e tem sido tema de acalorados debates. Apesar do seu potencial, não foi sob a sede do veto, entretanto, que essa discussão evoluiu. Não mais se questiona o veto parcial, previsto no atual texto constitucional.

A respeito do veto parcial justificado pelas emendas indevidas, Spitzer (1997) argumenta que as duas questões são separadas. A prática de se incluírem vários objetos em uma única lei é antiga e era de conhecimento dos constituintes originários dos Estados Unidos, tanto quanto o era a possibilidade de veto parcial. Ainda assim não o previram expressamente, o que até hoje ocasiona discussões sobre essa possibilidade. Apesar do apoio dos juristas, a maior parte dos cientistas políticos daquele país é contrária ao instituto que, aqui, prosperou desde a primeira hora da República.

O veto parcial, por suas características e pelos efeitos percebidos, não pode ser lido como um poder negativo no processo legislativo, tendo funcionado como uma emenda supressiva, acatada tacitamente pelo legislador. Sua adoção provoca, como se verá, alterações na natureza do instituto de veto, bem como em seus efeitos sobre o sistema político estudado. Em sua pesquisa a 18 países da América Latina, Aleman e Schwartz (2006) encontram que 10 deles aplicam o

${ }^{8}$ Legística seria, segundo definição de Delley e Flückiger (2007) “uma metodologia da concepção da ação pública e de sua tradução normativa, que procura determinar as melhores modalidades de elaboração, de redação, de edição e de aplicação da norma” (p.36) 
chamado "veto-emenda", que adiciona elementos textuais aos projetos aprovados pelos Legislativos. Conclui que o instituto do veto revela, para a América Latina uma conformação produtiva, ao contrário do esperado pela crítica, chegando a existir um veto construtivo na modalidade de projeto alternativo.

A vantagem estratégica do veto parcial reflete a capacidade de estabelecimento de agenda do Presidente da República (RASCH, 2014). Isso ocorre porque o veto parcial é acompanhado da modificação seletiva do status quo pela parte do projeto que é promulgada. A agenda sofre uma dupla ação do veto parcial, portanto: a primeira é de conteúdo (agenda de temas), como exposto, e a segunda dá-se sobre o tempo (agenda cronológica), na medida em que mesmo o veto parcial a um inciso de uma lei, demanda do Congresso o mesmo esforço da apreciação de um veto a mil dispositivos.

\subsection{Prazo contra o Congresso}

O tempo é fator crucial em qualquer processo decisório, o que é acentuado no processo decisório político, marcado pela lógica da escolha racional, e inteligível a partir dos modelos de jogos. Nota-se que as regras elencadas referentes ao prazo para o Congresso Nacional e as respectivas sanções são as que mais frequentemente deixaram de ser regradas pelas constituições brasileiras. Além disso, antes de 1988, apenas as constituições do Império e do Regime Militar haviam incluído sanções ao descumprimento do prazo de apreciação dos vetos.

A atual Constituição inovou ao atribuir uma sanção que toca o cerne do poder de agenda do Congresso Nacional: a pauta deliberativa. Pela primeira vez, em regime democrático e republicano, o constituinte originário decide autoinfringir-se uma agenda que restringe seu próprio raio de ação no exercício de sua função precípua no exato momento do processo decisório em que outro poder o exerce de modo atípico.

Também como reflexos sobre o tempo decisório, duas outras exigências herdadas do Regime Militar somam-se a essa inovação: a sessão conjunta com votos separados e o quórum de maioria absoluta de deputados e senadores de cada Casa, para rejeitar o veto. É forçoso concluir 
que a engenharia constitucional do veto produziu atores em posição de intensa assimetria no processo decisório legislativo, conforme se confirmará ao longo da discussão.

\subsection{0 veto da Constituição de 1988}

O instituto juspolítico do veto encontra-se delineado da seguinte forma no texto constitucional original de 1988 (BRASIL, 1988):

“Art. 66. A Casa na qual tenha sido concluída a votação enviará o projeto de lei ao Presidente da República, que, aquiescendo, o sancionará.

$\S 1^{\circ}$ Se o Presidente da República considerar o projeto, no todo ou em parte, inconstitucional ou contrário ao interesse público, vetá-lo-á total ou parcialmente, no prazo de quinze dias úteis, contados da data do recebimento, e comunicará, dentro de quarenta e oito horas, ao Presidente do Senado Federal os motivos do veto.

$\S 2^{\circ} \mathrm{O}$ veto parcial somente abrangerá texto integral de artigo, de parágrafo, de inciso ou de alínea.

$\S 3^{\circ}$ Decorrido o prazo de quinze dias, o silêncio do Presidente da República importará sanção.

$\S 4^{\circ} \mathrm{O}$ veto será apreciado em sessão conjunta, dentro de trinta dias a contar de seu recebimento, só podendo ser rejeitado pelo voto da maioria absoluta dos Deputados e Senadores, em escrutínio secreto.

$\S 5^{\circ}$ Se o veto não for mantido, será o projeto enviado, para promulgação, ao Presidente da República.

$\S 6^{\circ}$ Esgotado sem deliberação o prazo estabelecido no $\S 4^{\circ}$, o veto será colocado na ordem do dia da sessão imediata, sobrestadas as demais proposições, até sua votação final.

$\S 7^{\circ}$ Se a lei não for promulgada dentro de quarenta e oito horas pelo Presidente da República, nos casos dos $\S 3^{\circ}$ e $\S 5^{\circ}$, o Presidente do Senado a promulgará, e, se este não o fizer em igual prazo, caberá ao Vice-Presidente do Senado fazê-lo.” (negritos nossos).

O artigo em questão insere-se na subseção das “Leis”, que faz parte da seção referente ao "Processo Legislativo", ambas pertencentes ao capítulo pertinente ao Poder Legislativo. Em outras palavras, a prerrogativa presidencial insere-se no bojo textual de outro ramo de poder, constituindo poderes especiais legislativos, atribuídos ao chefe do Executivo, e consagrando a 
participação prevista no sistema tripartite de divisão dos poderes; exclui a possibilidade de vetos a projetos que não sejam de lei, no sentido estrito, como os projetos de resolução de decreto legislativo, além das propostas de emenda à Constituição.

O artigo refere-se à sanção. O texto constitucional inicia do aspecto positivo na fase constitutiva da lei (SILVA, 2006), para tratar do veto nos parágrafos. O parágrafo primeiro estabelece o verbo vetar como operacionalizador do poder de veto, e não negativa de sanção como em textos constitucionais anteriores, além de inserir quatro características do instituto: tipos total e parcial; categorias de motivações jurídicas (inconstitucional) ou políticas (contrário ao interesse público); prazo de 15 dias para o presidente vetar, com respectivo termo de início de contagem; e prazo de 48 horas para comunicação da decisão necessariamente motivada. O parágrafo segundo enumera as partes do projeto passíveis de veto: texto integral de artigo, parágrafo, inciso ou alínea, o que exclui o “item” (ou “número”) como parte vetável.

O parágrafo terceiro estabelece a sanção tácita da lei, em caso de perda do prazo de quinze dias. O parágrafo quarto marca quatro regras básicas de apreciação do veto: sessão conjunta de senadores e deputados; prazo de 30 dias para que se decida sobre o veto, antes de se trancar a pauta; quórum para a rejeição, de maioria absoluta da composição de cada uma das casas do Congresso Nacional; e escrutínio secreto, pouco frequente na história constitucional, e abolido pela Emenda Constitucional n 76, de 2013 (BRASIL, 2013).

O parágrafo quinto estabelece sanção para caso de rejeição do veto, que é a promulgação compulsória, pelo presidente, do projeto ou parte dele. O parágrafo sexto estabelece a regra de agenda forçada das sessões conjuntas, como sanção ao descumprimento do prazo de 30 dias, previsto no parágrafo quarto. A consequência é o chamado sobrestamento das demais proposições, durando enquanto durar a mora.

Conclui-se que o constituinte originário preocupou-se em manter a palavra final com o Legislativo, no que tange a formação da lei. Ao contrário do que ocorria em todos os textos constitucionais anteriores, não é mais o projeto vetado a retornar para nova apreciação do Congresso, mas o próprio veto, ou seja, os autógrafos retornam encimados por uma mensagem presidencial que expõe as razões de cada veto, total ou de cada parte vetada parcialmente, conforme o caso, sendo que o objeto processual a sofrer a tramitação formal é o veto, e não o 
projeto com sua numeração inicial. Essa leitura traz consequências para o procedimento legislativo (OLIVETTI, 1998).

Note-se que o texto constitucional não estabelece quórum para manutenção do veto, mas para sua rejeição apenas. Já a regra do escrutínio secreto vigorou de 1988 a novembro de 2013, quando, em contexto de pressão popular por maior transparência do Poder Legislativo, foi extinta a votação secreta do veto, regra tida originalmente por defesa do interesse parlamentar, mas que com a experiência histórica, passou a ser vista pela opinião pública como privilégio desproporcional.

Ao contrário do que o percurso histórico nos faria concluir, um Presidente da República submetido à Constituição Federal brasileira de 1988 (BRASIL, 1988) não tem o poder vetar por lhe faltar o poder legislar, pois o veto seria a instituição coerente de resistência à formação da legislação deletéria ao ordenamento jurídico e ou aos interesses públicos. O articulado constitucional delineia um órgão praticamente desprovido da necessidade de reagir ao Poder Legislativo no que tange ao comando da roupagem legal dos planos, programas e políticas de Governo, restando invertido o papel de poder reativo.

Nos comentários de Schwartz (1966) sobre a origem dos poderes legislativos do presidente norte-americano, quando de feitura da constituição dos Estados Unidos, identifica-se a justificação para o fortalecimento do ramo Executivo (chamado pelo autor de Magistratura), qual seja: sua fraqueza perante o ramo Legislativo (chamado de Legislatura). É essa a raiz institucional do veto.

Grohmann (2003), ao estudar o veto no Brasil, nos períodos democráticos anteriores (1946-1964) e posterior (1990-2000) à experiência autoritária do regime militar, contrasta a efetividade governativa detectada nos dois períodos, para apontar a fragmentação decisória e ineficiência do primeiro período em face da maior predominância dos presidentes do segundo período, com resultados mais proveitosos. Ou seja, existe o pressuposto, nos dois casos, de um legislativo forte ao qual se tem que reagir. Essa seria a justificativa histórica do escopo constitucional do Poder Executivo imperial brasileiro: um Legislativo muito poderoso, em tese, e um Presidente da República poderoso, na prática. 
Os estudos atuais dedicados ao sistema político brasileiro, mais especificamente à relação entre Executivo e Legislativo, apontam, na experiência concreta, a negação da característica de reatividade do veto brasileiro, tendo em vista os amplos poderes legislativos presidenciais. O que será analisado aqui, pela compreensão do regime de apreciação do veto pelo Congresso Nacional, no pós-1988, considerando-se essa deliberação do Legislativo o poder reativo de fato.

Estabelecido esse contexto de origem, o que se propõe é analisá-lo pelo viés de sua apreciação pelo Congresso. Uma vez que se concebe que a vida do instituto não estaria satisfatoriamente analisada sem que se analisasse essa fase, sediada no âmago do lócus da formação da lei. Por meio da apreciação do veto, pretendem-se compreender o poder de agenda concreto do Legislativo, seus mecanismos e expressões, para, por fim, analisar as consequências dessas alterações institucionais para o veto e para o sistema em que ele se insere. A seção seguinte descreve, legislatura por legislatura, o histórico de apreciação do instituto desenhado em 1988.

\subsection{Regras e Procedimentos}

O conhecimento do procedimento legislativo (Lamounier, 2005), conjunto de regras de funcionamento que ditam o ritmo e a forma do processo legislativo, é matéria que vem despertando interesse crescente da ciência política. As regras do processo legislativo formam um complexo institucional decisório cuja compreensão pode contribuir para os estudos legislativos, sendo, como já referido, bases sobre as quais se assenta o aspecto concreto do estabelecimento da agenda.

As regras e procedimentos legislativos advêm predominantemente dos textos constitucionais e regimentos internos dos parlamentos, mas também surgem de acordos e soluções temporárias adotadas em razão da conjuntura (MULLER E SIEBERER, 2014). Elas promovem o balizamento tanto do decidir, conforme poder de agenda, quanto do deixar de decidir. 
Descrevem-se na presente seção tanto o escopo constitucional e regimental, a formalização mais evidente dos acordos, quanto as criações procedimentais que de algum modo refletem sobre o resultado do processo legislativo. A descrição desses procedimentos, acompanhada de reflexão analítica, contribui para a compreensão das expressões concretas do poder de agenda do Congresso, no processo decisório de veto.

O texto constitucional fixa cinco regras básicas para a apreciação do veto: a primeira é a votação em sessão conjunta; a segunda, o prazo de até trinta dias para que isso ocorra; a terceira, o quórum de maioria absoluta de cada Casa para a rejeição, ou “derrubada”, do veto; a quarta, o envio à promulgação da parte vetada cujo veto seja rejeitado; e a quinta, a inclusão compulsória, na pauta da sessão conjunta, do veto com prazo de até trinta dias esgotado, bem como o sobrestamento de todas as demais proposições, até sua votação final. Acrescente-se a alteração promovida pela Emenda constitucional $n^{0}$ 76, de 18 de novembro de 2013 (BRASIL, 2013), que suprimiu a votação secreta de vetos.

No âmbito regimental, o regramento da tramitação de vetos permaneceu como o prescrito na Resolução do Congresso Nacional $n^{\circ}$ 1, de 1970, o Regimento Comum do Congresso Nacional (BRASIL, 1970), aprovada durante o regime constitucional de 1967 (com redação da Emenda Constitucional $n^{0} 1$, de 17 de outubro de 1969). As duas diferenças entre os dois regimes constitucionais são o quórum, que foi de 2/3 dos presentes para maioria absoluta dos membros, e a modalidade de votação, que foi de aberta para secreta (até novembro de 2013, conforme exposto). Isso não impactou consideravelmente na aplicabilidade de três dos cinco artigos regimentais que regulavam a matéria, os quais foram, assim, tacitamente recepcionados pelo novo texto constitucional. Os dois artigos revogados tratavam, respectivamente, do quórum e da competência exclusiva do Senado Federal para deliberar sobre vetos presidenciais apostos a projetos referentes ao Distrito Federal.

Os três artigos subsistentes tratam dos seguintes assuntos: marco inicial da contagem do prazo constitucional de 30 dias (sessão conjunta em que o veto é “conhecido”); a composição de comissão mista incumbida de elaborar um relatório indicativo de estudo do projeto vetado; e a referência à instrução da matéria antes de sua inclusão em ordem do dia da sessão conjunta, conforme calendário, com ou sem o relatório da comissão mista. Importa considerar, ainda, entre outras, as regras regimentais de condução das sessões conjuntas, como a regra que estabelece a 
duração de 4 horas para a sessão conjunta, com possibilidade de prorrogação para conclusão de votação iniciada (art. 22).

O texto atualmente vigente do Regimento Comum do Congresso Nacional remonta ao período do regime militar. Seu caráter centralizador parece ter-se adaptado sem maiores dificuldades às práticas legislativas pós 1988. A essa característica some-se a chamada subsidiariedade regimental, definida pelo art. 151 do Regimento Comum:

“Art. 151. Nos casos omissos neste Regimento aplicar-se-ão as disposições do Regimento do Senado e, se este ainda for omisso, as do da Câmara dos Deputados.” (BRASIL, 1970, negritos nossos).

Apesar da conhecida função de fonte primária do processo legislativo ordinário, o regimento da Câmara dos Deputados permaneceu como segundo recurso para o processo legislativo das sessões conjuntas, além das esperadas questões controversas advindas da interpretação da expressão “casos omissos” em situações concretas.

As regras regimentais foram modificadas pela Resolução do Congresso Nacional $n^{0} 1$, de 11 de julho de 2013 (BRASIL, 2013). As alterações deram-se em três pontos: mudança do marco inicial da contagem do prazo constitucional de 30 dias (da sessão convocada para “conhecimento" do veto para a data de protocolização da mensagem de veto junto à Presidência do Senado Federal); reafirmação redundante do comando constitucional de inclusão obrigatória do veto com prazo constitucional esgotado em ordem do dia da sessão conjunta; e estabelecimento de calendário obrigatório próprio para apreciação de vetos, às terceiras terçasfeiras de cada mês. Destaca-se, ainda, a cláusula de incidência parcial da norma, restrita a vetos publicados a partir de $1^{\circ}$ de julho de 2013, cujo efeito incomum será evidenciado.

Além do escopo constitucional e regimental, considera-se igualmente importante descrever a evolução dos usos e costumes regimentais que, ao longo das sete legislaturas estudadas, formataram o processo decisório de veto pelo Congresso Nacional. Analisam-se os efeitos da aplicação e alteração das regras e procedimentos para o rendimento legislativo, bem como se consideram algumas externalidades relevantes, advindas da ordem eleitoral, política e 
econômica. Esse acréscimo enriquece a discussão ao incluir aspectos importantes da vida do Legislativo. Os resultados estão dispostos por legislatura, nas secções a seguir, sendo que a análise detalhada é oferecida no Capítulo 4.

\subsubsection{8 ${ }^{\mathrm{a}}$ Legislatura (1988 (outubro) - 1990): Presidências do Congresso de Humberto Lucena (PMDB) e Nelson Carneiro (PMDB) - Presidência da República de José Sarney (PMDB).}

Desde o primeiro momento da nova vida constitucional o painel eletrônico foi o procedimento preferido para as votações dos vetos. Isso parece dever-se tanto à praticidade quanto ao costume formado durante os trabalhos da Assembleia Nacional Constituinte.

Os deputados e senadores dessa legislatura acumularam suas atividades parlamentares regulares com as das sessões unicamerais da Assembleia Nacional Constituinte, que se reuniu em plenário conjunto em 341 sessões (de $1^{\circ}$ de fevereiro de 1987 a 5 de outubro de 1988). É de se supor, portanto, que a metodologia e também o ritmo de trabalho conjunto tenham perdurado pelo tempo imediatamente subsequente à promulgação da Constituição.

Na sessão ocorrida em 30 de novembro de 1988, a primeira sessão de vetos pós 1988, a presidência esclarecia:

“A Presidência esclarece que, de acordo com o disposto no $\S 4^{\circ}$ do art. 66 da Constituição, a votação far-se-á em escrutínio secreto. Nos termos do art. 43, § 29, do Regimento Comum, a votação será iniciada pela Câmara. Lembro ao Plenário que a votação refere-se ao veto presidencial e não ao Projeto.” (DCN 1/12/1988 - negrito nosso).

Essa compreensão permanece até os dias de hoje, quando o veto é um tipo legislativo individual, obtido a partir da autuação processual da mensagem do Presidente da República, e ao qual se aplicam, individualmente, diversas disposições regimentais, como se verá.

A votação global do veto parcial foi a primeira decisão procedimental relevante no procedimento legislativo do veto. Foi o que ocorreu com o veto da Mensagem n ${ }^{\circ} 27$ de 1989, 
aposto ao projeto de lei orçamentária anual para 1989, vetado em 171 partes, incluindo anexos orçamentários, ou seja, potencialmente, seriam 171 votações, com consequências presumivelmente negativas para o andamento da agenda legislativa.

Mas, a votação global era questionável, visto que projetos vetados parcialmente cujas partes tratem de assuntos diversos, poderiam ocasionar a fusão de votações globais de assuntos heterogêneos. O congressista Ibsen Pinheiro empregou essa argumentação (sessão de 5 de abril de 1989), sensibilizou a presidência e a partir dali, a votação dos vetos parciais passou a ser parte a parte (BRASIL, 05/04/1989, p. 964)

Também em 1989 já ocorre o primeiro caso de prejudicialidade de veto. Trata-se de instituto regimental destinado a evitar que se tome uma decisão inócua sobre uma matéria, ou por já ter sido deliberada pela mesma instância, ou por ter perdido a oportunidade, o que se supõe tratar de questão temporal. No curso da votação do veto da Mensagem nº 177 de 1989, depois da votação do parágrafo de um determinado artigo, o presidente anunciou a não votação do parágrafo seguinte, por “[...] se tratar de matéria correlata.” (BRASIL, 28/11/1989, p. 4995).

A decisão inicial de votação do veto parcial parte a parte foi logo superada, com a votação de parecer da Comissão de Constituição e Justiça e de Redação, da Câmara dos Deputados, emitido por solicitação do Presidente do Congresso Nacional, Senador Nelson Carneiro, em face do questionamento feito pelo Deputado Gerson Peres quanto à dificuldade de se votarem os vetos parciais de modo múltiplo (dispositivo por dispositivo). A votação do parecer foi feita entre os líderes, de modo simbólico, tendo sido considerada unânime a sua aprovação, contrariada a opinião do Presidente (BRASIL, 26/6/1990, p. 3376).

Essa decisão parece não ter causado efeitos sobre a quantidade de sessões efetivas (em que se votaram vetos) a partir dali, conforme o gráfico da Figura 4. 
Figura 4: Gráfico das sessões mensais efetivas em 1990 (março em diante).

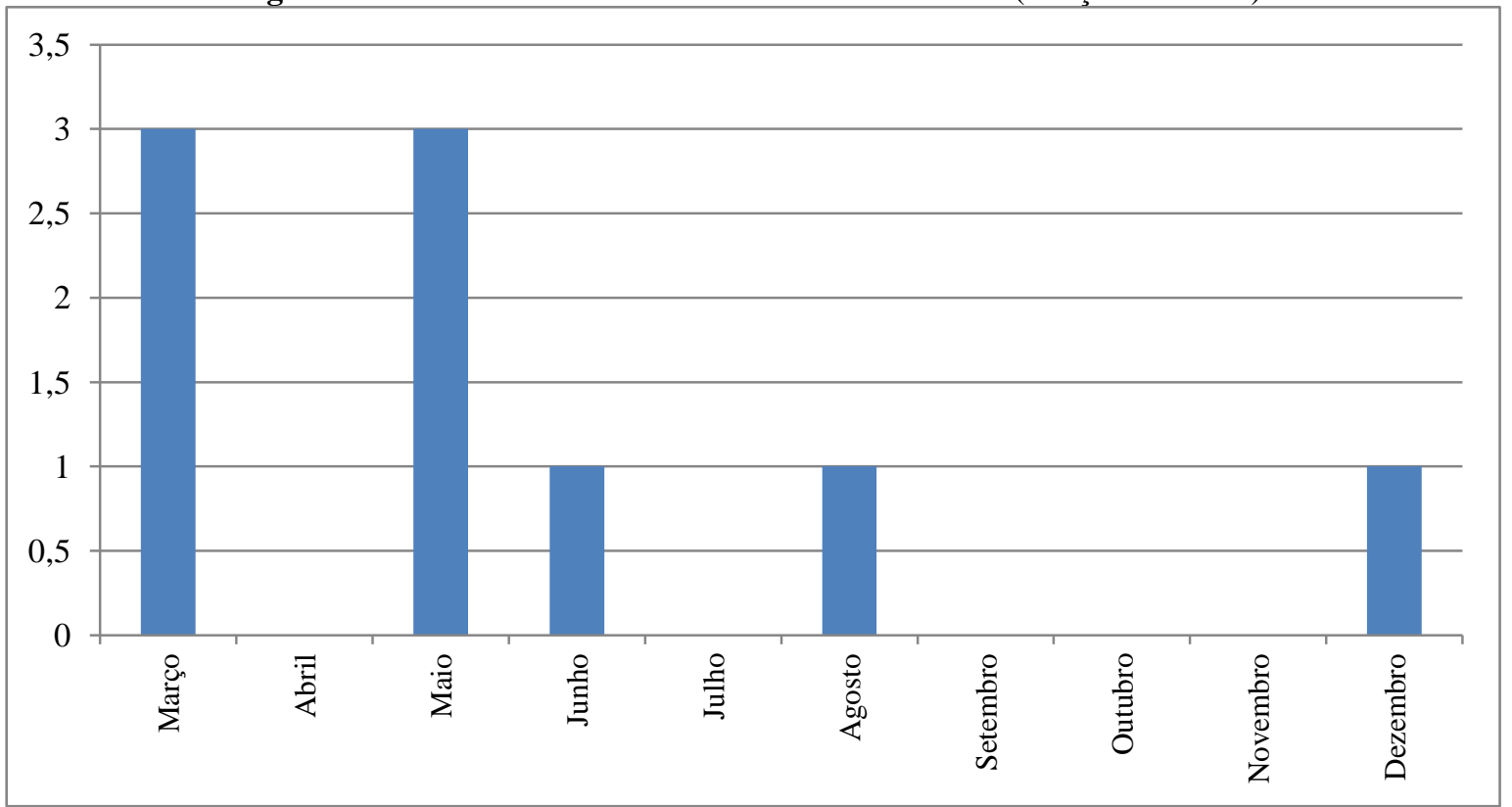

Fonte dos dados brutos: Sistemas de Informação do Senado Federal e da Câmara dos Deputados, Diário do Senado Federal e do Congresso Nacional; Relatório Anual da Presidência do Senado Federal.

Nota-se que a partir do mês de junho, quando da alteração referida, as sessões conjuntas permaneceram com o mesmo ritmo raro de ocorrência. Facilitar a votação não parecer ter tido efeitos sobre a decisão de deliberar sobre vetos. Ao mesmo tempo, note-se que se tratava de um ano eleitoral, em que se elegeram os nomes para os Executivos estaduais e para os Legislativos estadual e federal. Os anos eleitorais, principalmente os de eleições gerais, parecem acarretar a redução do ritmo de trabalho legislativo. Os gráficos da Figura 5 abaixo auxiliam no aclaramento da questão. 
Figura 5: Gráficos das sessões efetivas de vetos - legislaturas ano a ano
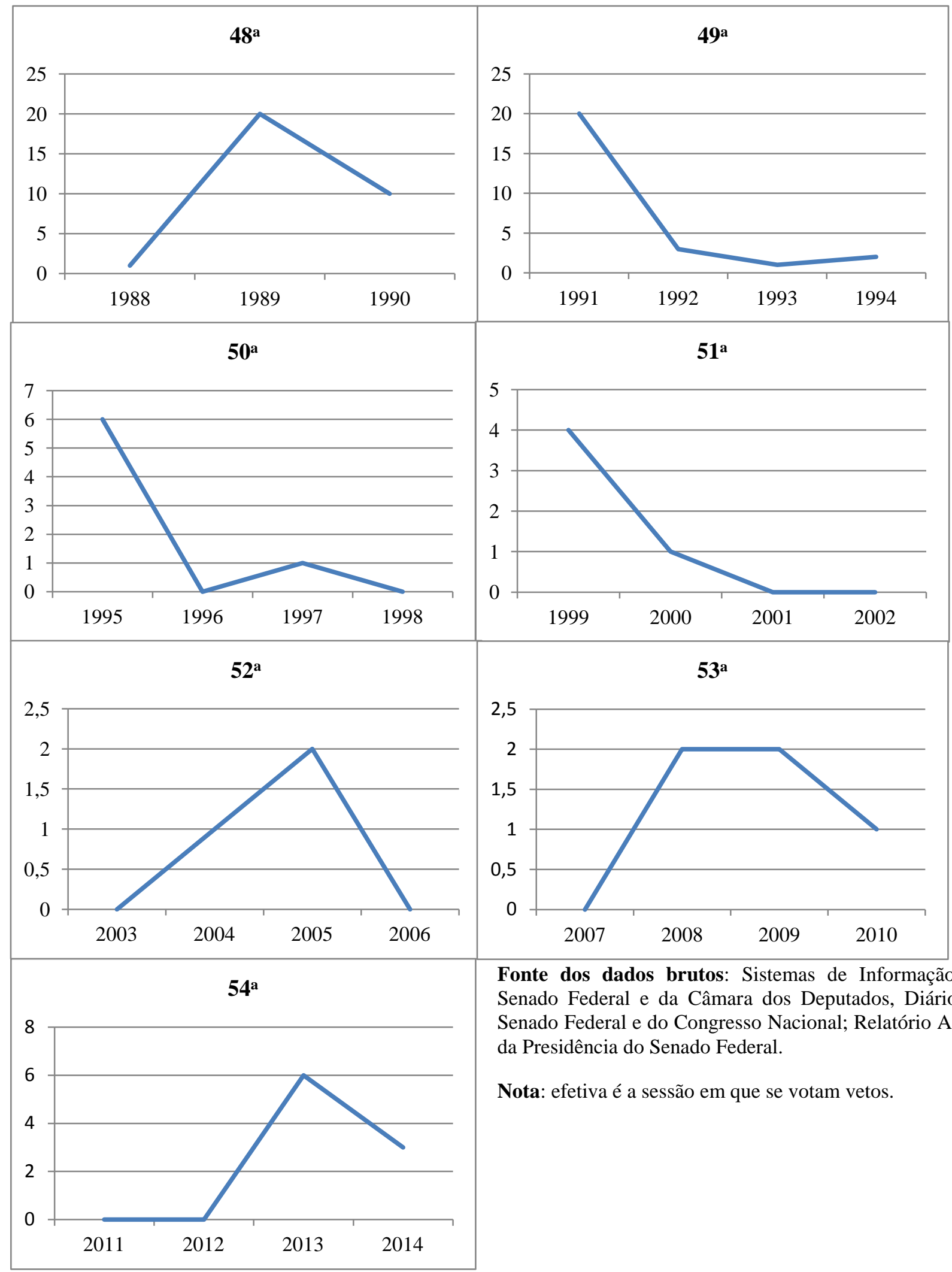

Fonte dos dados brutos: Sistemas de Informação do Senado Federal e da Câmara dos Deputados, Diário do Senado Federal e do Congresso Nacional; Relatório Anual da Presidência do Senado Federal.

Nota: efetiva é a sessão em que se votam vetos. 
De fato, a $48^{\mathrm{a}}$ Legislatura não só respondeu pela elaboração de uma nova Constituição como também participou de três processos eleitorais importantes: as eleições municipais de 1988, a eleição do Presidente da República de 1989 e as já referidas eleições de 1990 (NICOLAU, 2012). Não é de se espantar que arena legislativa estivesse relativamente relegada. Não se tratava apenas de eleições regulares, mas de processos que consolidavam o a redemocratização do país, depois de mais de 20 anos de democracia eleitoral enfraquecida.

Paralelamente, uma prática constitucional de grande relevância começa a ser utilizada já na primeira legislatura da Constituição de 1988 (BRASIL, 1988a): a reedição de Medidas Provisórias. O primeiro caso foi a Medida Provisória n 39, de 1989 (ver FIGUEIREDO E LIMOMGI, 1999, para detalhes sobre o caso). O texto original da Constituição estabelecia o prazo de 30 dias de vigência de medida provisória, mas silenciava quanto à possibilidade de sua reedição, em face da não decisão do Congresso sobre ela. O resultado foi a utilização crescente do recurso de reedição, combinado com o recurso de não decisão do Congresso sobre medidas provisórias reeditadas.

Originalmente, essas matérias eram apreciadas em sessões conjuntas, com preferência inclusive sobre os vetos presidenciais ${ }^{9}$. Boa parte do tempo das sessões conjuntas durante a $48^{\mathrm{a}}$ Legislatura era dedicado às medidas provisórias, dificultando inclusive a apreciação dos vetos. A partir da 49a Legislatura, a intensificação da prática da reedição parece ter tido um efeito considerável sobre a agenda concreta das sessões conjuntas, com consequente redução das sessões convocadas para tratar de vetos, além das grandes dificuldades de quórum.

Sendo assim, já em 1990, segundo ano da Constituição nova, a quantidade de sessões conjuntas em que se pautassem vetos era reduzida. Das 105 sessões deliberativas convocadas, em apenas 68 delas pautaram-se vetos. Desse número, apenas 10 delas obtiveram quórum para votálos (menos de 10\%), ou seja, foram efetivas. É razoável supor que houvesse conflitos entre os dois poderes, manifestos nos vetos, cuja apreciação efetiva nos fornecesse subsídios para conclusões diversas. No entanto, o que já se percebe é a ausência do evento a ser observado.

\footnotetext{
${ }^{9}$ Nos termos da redação original do $\S 6^{\circ}$ do art. 66 da Constituição de 1988 (BRASIL, 1988a).
} 
Em resumo, a $48^{\mathrm{a}}$ legislatura já oferece exemplos de adaptações nas regras regimentais para propiciar a apreciação mais efetiva de vetos. Apesar disso, dois outros fatores interferentes figuraram como mais impactantes para compreensão do ritmo deliberativo do Congresso: as medidas provisórias, notadamente a prática de reedições, e os processos eleitorais. Os efeitos da arena eleitoral, bem como das regras constitucionais parecem ser mais impactantes que as adaptações regimentais (prejudicialidade e votação global de vetos parciais).

O escopo constitucional, por sua vez, traz para o Congresso o veto como matéria autônoma e o quórum de maioria absoluta em sessão conjunta como complicadores da agenda, com os quais será preciso lidar nos anos que se seguirão. Foram realizadas na legislatura 130 sessões com vetos em pauta, para a resolução de 81 vetos, em 31 delas. Desse modo, a 49a Legislatura herdou 44 vetos não apreciados pela $48^{a}$ legislatura. Esse estoque transferido passará a ser regra no sistema decisório de vetos.

\subsubsection{9ª Legislatura (1991-1994): Presidências do Congresso de Mauro Benevides (PMDB) e Humberto Lucena (PMDB) - Presidências da República de Fernando Collor (PRN) e Itamar Franco (PRN/PMDB).}

Em 1992, findo o mês de abril, com as experiências de 1988 a 1991, haviam sido tentadas 14 sessões conjuntas, ao longo de três meses, todas sem sucesso e a pauta contava já com quase 70 vetos presidenciais. A situação foi solucionada com a criação da cédula única de votações.

Para a sessão convocada para 14 de maio de 1992 foram confeccionadas cédulas únicas, oriundas de discussões iniciadas já no final de outubro de 1991. Essas cédulas foram entregues, com antecedência, por correspondência do Presidente do Congresso Nacional, nos gabinetes de todos os parlamentares. Conforme se vê do testemunho do Deputado Prisco Viana:

"Sr. Presidente, não é possível que adotemos esse processo. Cheguei ao meu gabinete hoje, às 8 horas. Às $8 \mathrm{~h} 30 \mathrm{~min}$, recebi uma correspondência de $\mathrm{V}$. Exa , contendo uma cédula única para a votação de hoje. Ora, Sr. Presidente, o processo representa um perigoso e grave precedente”. (BRASIL, 14/5/1992, p. 590) (negritos nossos). 
O Presidente da Mesa mais uma vez argumentou sobre acordo anterior quanto ao emprego do mecanismo da cédula para limpar a pauta de vetos, chamou a atenção para o grande número de votações que o Congresso teria a sua frente, em face do pouco tempo disponível e acentuou que com a cédula, todas as matérias estariam automaticamente destacadas:

“E ainda mais com essa cédula, livramos o Plenário das decisões que concedem destaque ou não. Destacamos todas as matérias.” (idem) (negritos nossos).

Aduziu ainda que se tratava de recurso previsto regimentalmente:

“A Mesa sente-se no dever de lembrar também que o Regimento Comum, no seu art. 47, estabelece:

"Na votação secreta, o Congressista chamado receberá uma sobrecarta opaca, de cor e tamanho uniformes, e se dirigirá a uma cabine indevassável, colocada no recinto, na qual deve encontrar cédulas para votação. Após colocar na sobrecarta a cédula escolhida, lançá-la-á na urna, que se encontrará no recinto, sob a guarda de funcionários previamente designados".” (idem).

Entre os argumentos empregados sobre a cédula, destacam-se alguns excertos:

- “A rigor, estamos instituindo o voto por correspondência [...]” (Deputado Prisco Viana) (idem) (negritos nossos).

- "Aqueles itens que podem ser votados em uma cédula, acordadas as lideranças e consultadas as bancadas, faremos um procedimento desse tipo, aqueles itens mais polêmicos deverão ser reservados para a votação tradicional [...]” (Deputado Eduardo Jorge) (ibidem, p. 593) (negritos nossos).

- "[...] inúmeras matérias, as mais controvertidas, as mais polêmicas e algumas de absoluto desconhecimento da grande maioria dos Srs. Congressistas serão votadas de uma só vez.” (Deputado Paulo Mandarino) (ibidem, p. 594) (negritos nossos).

- "Entendemos que essas matérias, esses vetos são importantes e que não poderíamos jamais correr o risco de uma votação em bloco, como aqui foi colocada, pois foge completamente do sentido do voto secreto.” (Deputado Tony Gel) (idem) (negritos nossos).

- “[...] o aspecto político que há nessa votação célere e também para o aspecto social, porque a sociedade cobra todo dia, toda hora e a imprensa nos castiga exatamente por essa lentidão.” (Senador Cid Sabóia) (ibidem, p. 595) (negritos nossos).

- “[...] Ao votarmos através da cédula, estaremos, conseqüentemente, fazendo com que o voto deixe de ser secreto, para se tornar público. E, no trabalho de votação, consegue-se prejudicar a discussão de veto por veto, principalmente os interesses do projeto em si, em pauta e na hora da votação. Para ser bem curto e bem grosso, penso que essa idéia, não deve ser aceita pela Casa.” (Deputado Nelson Marquezzelli) (idem) (negritos nossos). 
- “[...] Entendemos que o Regimento não dá amparo legal para votação de vetos com cédulas.” (Deputado Humberto Souto - Líder do Governo) (ibidem, p. 596) (negritos nossos).

O Presidente apelou para a demanda da conjuntura do acúmulo de vetos (67 naquela sessão), além da dificuldade de espaço físico, uma vez que as sessões conjuntas realizam-se, em regra, no Plenário da Câmara:

“[...] na atual conjuntura não temos condições de votar mais do que quatro, ou, quando muito, cinco vetos presidenciais. Até para obter o espaço de sessão aqui há instâncias realizadas junto ao Presidente da Câmara que, na apreciação das matérias pertinentes a esta Casa do Congresso, também é obrigado a ocupar os espaços nobres, que são as tardes destinadas à Ordem do Dia da Câmara dos Deputados.” (ibidem, p. 591) (negritos nossos).

E enfatizou mais uma vez o caráter extraordinário da cédula:

"Portanto, era o esclarecimento que a Mesa desejava transmitir a todos os Srs. Parlamentares, esclarecendo que a utilização dessa cédula só se fará nessa conjuntura, nessa emergência, tendo em vista o acúmulo de quase 70 vetos na Ordem do Dia." (BRASIL, 20/5/1992, p. 625) ( negrito nosso).

A título de ilustração, segue um pequeno excerto da cédula única de votação (Figura 6): 
Figura 6: Cédula Única de Votação

\begin{tabular}{|c|c|c|c|c|}
\hline MATÉRIA & \multicolumn{3}{|c|}{ VOTO } & \\
\hline 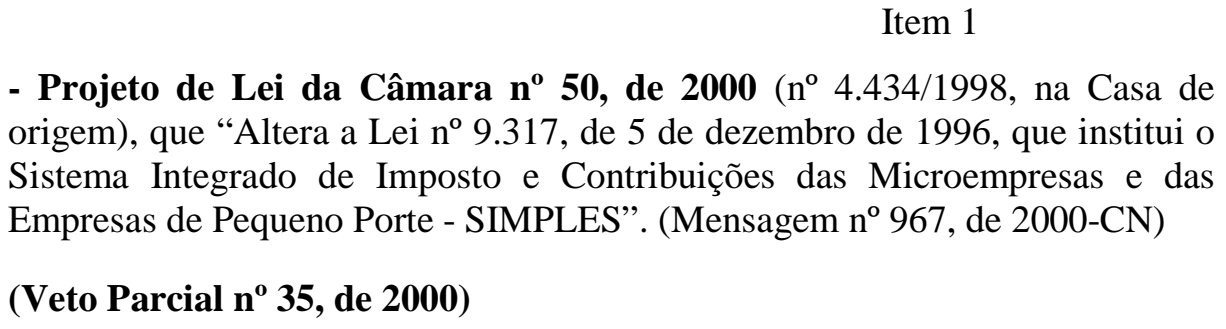 & & & & \\
\hline$-\operatorname{art.} 3^{\circ}$. & S $\square$ & $\mathrm{N} \square$ & $\mathrm{A} \square$ & [01.01] \\
\hline $\begin{array}{l}\text { Item } 2 \\
\text { - Projeto de Lei da Câmara } \mathbf{n}^{\mathbf{0}} \mathbf{7 6} \text {, de } 2001 \text { (nº 66/1999, na Casa de origem), } \\
\text { que “Dispõe sobre a criação de Programa de Orientação Sexual, de Prevenção } \\
\text { das Doenças Sexualmente Transmissíveis e do Uso de Drogas”. (Mensagem no } \\
\text { 65, de 2002-CN) } \\
\text { (Veto Total no 10, de 2002) }\end{array}$ & $\mathrm{s} \square$ & $\mathrm{N} \square$ & $\mathrm{A} \square$ & [02.00] \\
\hline $\begin{array}{l}\text { Item } 3 \\
\text { - Projeto de Lei da Câmara } \mathbf{n}^{\mathbf{0}} \mathbf{1 0 8} \text {, de } \mathbf{2 0 0 2}\left(\mathrm{n}^{\mathrm{o}} \text { 7.015/2002, na Casa de }\right. \\
\text { origem), que "Institui o Fundo Constitucional do Distrito Federal - FCDF, } \\
\text { para atender o disposto no inciso XIV do art. } 21 \text { da Constituição Federal". } \\
\text { (Mensagem n } n^{\circ} \text { 345, de 2002-CN) } \\
\text { (Veto Parcial } \mathbf{n}^{\mathbf{0}} \mathbf{3 6} \text {, de 2002) }\end{array}$ & & & & \\
\hline$-\S 2^{\circ}$ do art. $1^{0}$ & $\mathrm{~S} \square$ & $\mathrm{N} \square$ & $\mathrm{A} \square$ & [03.01] \\
\hline - “caput” do art. 5\%; & $\mathrm{S} \bar{\square}$ & $\mathrm{N} \square$ & $\mathrm{A} \square$ & [03.02] \\
\hline - inciso I do art. $5^{\circ}$; & S $\square$ & $\mathrm{N} \square$ & $\mathrm{A} \square$ & [03.03] \\
\hline - inciso II do art. $5^{\circ}$; & $\mathrm{S} \square$ & $\mathrm{N} \square$ & $\mathrm{A} \square$ & [03.04] \\
\hline - inciso III do art. $5^{\circ}$; & $\mathrm{S} \square$ & $\mathrm{N} \square$ & $\mathrm{A} \square$ & [03.05] \\
\hline - inciso IV do art. $5^{\circ}$; & $\mathrm{S} \square$ & $\mathrm{N} \square$ & $\mathrm{A} \square$ & [03.06] \\
\hline - inciso V do art. $5^{\circ}$ & $\mathrm{S} \square$ & $\mathrm{N} \square$ & $\mathrm{A} \square$ & [03.07] \\
\hline - $\S 1^{\circ}$ do art. $5^{\circ}$ & $\mathrm{S} \square$ & $\mathrm{N} \square$ & $\mathrm{A} \square$ & [03.08] \\
\hline$-\S 2^{\circ}$ do art. $5^{\circ}$ & $\mathrm{S} \square$ & $\mathrm{N} \square$ & $\mathrm{A} \square$ & [03.09] \\
\hline$-\S 3^{\circ}$ do art. $5^{\circ}$ & $\mathrm{S} \square$ & $\mathrm{N} \square$ & $\mathrm{A} \square$ & [03.10] \\
\hline$-\S 4^{\circ}$ do art. $5^{\circ}$ & $\mathrm{s} \bar{\square}$ & $\mathrm{N} \square$ & $\mathrm{A} \square$ & [03.11] \\
\hline$-\S 5^{\circ}$ do art. $5^{\circ}$ & $\mathrm{S} \square$ & $\mathrm{N} \square$ & $\mathrm{A} \square$ & [03.12] \\
\hline - “caput” do art. 6\%; & $\mathrm{S} \square$ & $\mathrm{N} \square$ & $\mathrm{A} \square$ & [03.13] \\
\hline - inciso I do art. $6^{\circ} ;$ & $\mathrm{S} \square$ & $\mathrm{N} \square$ & $\mathrm{A} \square$ & [03.14] \\
\hline - inciso II do art. $6^{\circ} ;$ & $\mathrm{S} \square$ & $\mathrm{N} \square$ & $\mathrm{A} \square$ & [03.15] \\
\hline - inciso III do art. $6^{\circ}$; & $\mathrm{S} \square$ & $\mathrm{N} \square$ & $\mathrm{A} \square$ & [03.16] \\
\hline - inciso IV do art. $6^{\circ} ; \mathrm{e}$ & $\mathrm{S} \square$ & $\mathrm{N} \square$ & $\mathrm{A} \square$ & [03.17] \\
\hline$-\operatorname{art.} 7^{\circ}$ & s $\bar{\square}$ & $\mathrm{N} \square$ & $\mathrm{A} \square$ & [03.18] \\
\hline
\end{tabular}

Fonte: Arquivos da Secretaria Legislativa do Congresso Nacional. 
Nota-se que para cada item há um voto, tratando-se, portanto, de votação múltipla (vários dispositivos), simultânea e destacada parte a parte. A simultaneidade da votação é dupla: votam, a um só tempo, deputados e senadores, e votam toda a pauta.

As cédulas foram efetivamente utilizadas pela primeira vez em 20 de maio de 1992. A apuração dos votos, feita pela equipes técnicas da Secretaria-Geral da Mesa e de processamento de dados do Senado - Prodasen, deu-se com a presença de uma comissão apuradora formada por parlamentares indicados pelos partidos.

A sessão durou 1 hora e 50 minutos. Considerando cada "xis" marcado nas cédulas como uma votação, desconsiderando-se o tempo de sessão não dedicado à votação, tem-se 29 segundos por cada voto. Esse rendimento deliberativo fez do instrumento da cédula uma importante válvula de escape para resolução de vetos. A 48 ${ }^{a}$ legislatura havia tomado 31 sessões efetivas para solucionar 81 vetos (cerca de três por sessão). A 49 precisou de 26 sessões para solucionar 215 vetos (quase oito por sessão), e já na $50^{\mathrm{a}}$ legislatura, graças à cédula, foram apenas 7 sessões para a solução de 194 vetos (quase 27 por sessão).

A cédula modificou também o modo de contagem dos dispositivos vetados. Até esse ponto, a contagem de dispositivos propriamente dita não chamava atenção, sendo enfatizado o dispositivo por seu conteúdo. Assim, um artigo que se desdobrasse em parágrafos, incisos e alíneas, permanecia como um único dispositivo ou parte vetada, desde que formasse uma unidade de sentido. Com a cédula, instaurou-se a prática de contagem das partes. Um dos efeitos desse procedimento foi fazer da contagem dos menores itens da cédula um assunto de interesse geral, por vezes mais interessante do que o próprio conteúdo das matérias.

O processo legislativo das sessões conjuntas é marcado pela característica de plenário puro ou, como nominou Cox (2006), de um “estado de natureza legislativo”, em que não há comissões e as discussões tendem a ser intermináveis ${ }^{10}$. Mencionem-se, por exemplo, os dispositivos regimentais sobre discussão do veto, em vigor desde 1970, que facultam o mínimo

\footnotetext{
${ }^{10} \mathrm{O}$ autor retroprojeta a evolução das normas de deliberação dos plenários das assembleias democráticas ao longo da história, partindo de um início marcado pela singeleza das regras e chegando-se a um estado mais complexo, com comissões e controladores da agenda. Isso porque o “estado de natureza legislativo” levaria à escassez de tempo no plenário e um consequente gargalo decisório.
} 
de quatro senadores e seis deputados, falando por até vinte minutos em cada item da pauta, o que pode arrastar a discussão por mais de duas horas, por item.

A $49^{\mathrm{a}}$ Legislatura recebera da $48^{\mathrm{a}}$ um estoque de 44 vetos, que se somaram aos vetos novos. A duração da sessão do Congresso, 4 horas, em contexto de dissenso, ou mesmo de consenso em matérias de interesse geral, limitaria a discussão a dois itens da pauta, como se viu. Logo, seriam necessárias 22 sessões apenas para reduzir o estoque recebido da legislatura anterior. Sendo assim, a cédula única de votações funcionou também como um mecanismo de formalização do consenso e de racionalização dos trabalhos do plenário das sessões conjuntas.

Finalizada a primeira legislatura da pós 1988, a combinação de regras constitucionais e regimentais desenhava para o Congresso um processo decisório que desafiava sua agenda para além das possibilidades concretas de agir. Nesse contexto, a cédula de votação promoveu uma transformação da própria noção ordinária de discussão e votação, criando uma modalidade de processo legislativo inteiramente nova, em princípios e consequências, cuja principal característica é a fusão consensual de fases.

No processo legislativo ordinário, separam-se obrigatoriamente as fases de discussão e votação. Esse princípio do processo legislativo é consagrado por constitucionalistas como Silva (2006) e Ferreira Filho (2002), pois respeita a noção segundo a qual os parlamentares devem antes formar sua opinião para então votarem. Segundo a regra geral, depois da discussão e da votação, a fase subsequente é a apuração, seguida da declaração presidencial do resultado. Pelo processo apoiado pelo painel eletrônico, a apuração é imediata, sendo o anúncio do resultado igualmente imediato.

O processo legislativo de veto com cédula única funde discussão e votação, e exclui a apuração do âmbito da sessão. Os anais pesquisados atestam que a palavra passou a ser franqueada aos oradores interessados nos vetos pautados, de modo indistinto, enquanto as cédulas eram entregues junto às urnas. Já a votação ocorria de modo simultâneo e conjunto, pois as cédulas contendo votos de senadores e deputados eram entregues a um só tempo, ou seja, votavam-se o primeiro e o último veto da cédula ao mesmo tempo, nas duas Casas.

A apuração também se dava de modo separado. Concluído o processo de entrega das cédulas, os votos dos parlamentares deixava o recinto, acompanhados de uma comissão 
apuradora de parlamentares indicados pelos líderes, para que se procedesse à apuração dos votos. Esse procedimento chegava a durar dias. Ou seja, a apuração do voto parlamentar, imediata em relação à votação quando se emprega painel, pelo sistema de cédula única remove do bojo temporal da sessão conjunta o tempo que seria tomado pelo processo.

Esses dois aspectos, fusão de fases e separação de apuração, juntos, constituíram a principal vantagem operacional da cédula. Como já exemplificado, o rendimento deliberativo dos períodos anteriores e posteriores à cédula são marcadamente diferentes, sendo de cerca de três vetos por sessão antes, e de cerca de 30 vetos por sessão depois de sua implantação.

Embora o mecanismo não gozasse de status regimental ou constitucional, seu uso inaugura procedimento legislativo novo, excêntrico e especial sob os aspectos já levantados aqui, produzindo um efeito invulgar de ganho decisório pela produção de alto número de votações em espaço reduzido de tempo, mediante consenso prévio para o qual o procedimento de votação servia tão somente como homologação.

A despeito desse importante marco no processo decisório de veto, a 49a Legislatura transferiu um estoque ainda maior - 49 vetos - à 50a Legislatura. Foram realizadas 26 sessões efetivas, para resolver sobre 215 vetos. Mas se trata da legislatura com maior quantidade de vetos apostos pelo Presidente da República: 220. Esse mecanismo transformou o procedimento legislativo do veto, mas não reverteu a tendência de formação de estoques. O sistema legislativo, do qual faz parte o veto, a partir do escopo de 1988, gerou um fluxo de produção e apreciação de vetos extremamente desafiador para o Legislativo, onde mesmo com potentes mecanismos de votação, o déficit deliberativo era crescente.

Na arena política, registre-se que a segunda Legislatura pós-1988 viu operar pela primeira vez o instituto do impeachment, aplicado contra o Presidente Fernando Collor de Mello, que renunciou à presidência da República em 1992, em face da ação institucional centralizada pelo Congresso. No ano de 1991 houve 20 sessões efetivas de veto, enquanto no ano de 1992 foram apenas três. Em 1993, um plebiscito confirmou o sistema presidencialista. Em 1994 foi lançado o Plano Real, que levaria o então Ministro da Fazenda à presidência da República. 


\subsubsection{0 ${ }^{a}$ Legislatura (1995-1998): Presidências do Congresso de José Sarney (PMDB) e Antônio Carlos Magalhães (PFL) - Presidência da República de Fernando Henrique Cardoso (PSDB) (FHC I).}

Em sessão de 12 de agosto de 1997 é declarada a prejudicialidade de nove vetos, nos termos do art. 334, alínea 'a' do Regimento do Senado Federal, por haverem perdido a oportunidade (BRASIL, 12/08/1997, p. 6025). Como já mencionado, o instituto da prejudicialidade é incidente processual legislativo em que a instância decisória, plenários e comissões, vê-se diante de matéria por ele já tratada, ou matéria que haja perdido a oportunidade, ou seja, cuja apreciação resultará inócua por produzir objeto inerte. É declarado pelo Presidente, de ofício ou provocado, havendo ainda a previsão de recurso ao plenário.

Como exposto nas Seções 2.3 e 2.4.1, a partir da Constituição de 1988 (BRASIL, 1988), o veto passou a tramitar como matéria autônoma. Essa consideração é o pressuposto do qual depende a aplicação do instituto de prejudicialidade ao veto. De outro modo, seria impossível declarar o prejuízo de apreciação de qualquer veto, dado que a parte vetada corresponderia tão simplesmente a processo legislativo inconcluso, ainda que fosse considerado como negativa de sanção, ou seja, como retorno da matéria vetada ao Congresso para nova deliberação com novo quórum, o prejuízo de sua votação não teria o condão de rejeitá-lo, visto que para tanto existe comando constitucional expresso. Restaria, no entanto, a intenção de impedir que o plenário do Congresso deliberasse sobre matéria cuja apreciação resultaria em objeto inócuo.

Por outro lado, essa argumentação depende de um transcurso de tempo suficiente pra que outra deliberação tivesse produzido outro objeto, compreendido pela parte vetada. O prazo constitucional de 30 dias é curto também para que esse tipo de efeito sobre a segurança jurídica não seja produzido. Em outras palavras, a atração do instituto da prejudicialidade do veto pode ser vista como um efeito colateral da omissão congressual quanto ao prazo constitucional.

$\mathrm{Na} 50^{\mathrm{a}}$ Legislatura foram realizadas apenas 12 sessões, em que se resolveram 76 vetos, sendo 66 deles no primeiro ano da Legislatura, tendo sido transferidos 125 vetos para a $51^{\mathrm{a}}$ Legislatura, maior estoque transferido a outra Legislatura até ali. No último ano da Legislatura, pela primeira vez desde 1988, não houve sessões de vetos. O percentual de resolução foi bastante 
reduzido, em comparação com as legislaturas antecedentes; como se verifica no Quadro 2, o sistema atinge um extremo, consolidando procedimentos, mas principalmente reafirmando a tendência de não decisão.

Quadro 2: Percentual de Resolução de Vetos - Com Estoques - $48^{\mathrm{a}}$ à $50^{\mathrm{a}}$ Legislaturas (médias anuais)

\begin{tabular}{|c|c|}
\hline Legislatura & \% Resolução Média \\
\hline $48^{\mathrm{a}}$ & $68,1 \%$ \\
\hline $49^{\mathrm{a}}$ & $54,3 \%$ \\
\hline $50^{\mathrm{a}}$ & $\mathbf{1 7 , 3 \%}$ \\
\hline
\end{tabular}

Fonte dos dados brutos: Sistemas de Informação do Senado Federal e da Câmara dos Deputados, Diário do Senado Federal e do Congresso Nacional; Relatório Anual da Presidência do Senado Federal.

Notas:

- A resolução com estoques diz respeito aos vetos que tenham sido votados ou declarados prejudicados, independentemente do ano de aposição do veto (somados os estoques herdados).

- A 48 Legislatura inclui apenas 3 anos, em vista da promulgação da constituição em 1988 e eleições do Legislativo em 1990.

Ao mesmo tempo, porém, essa legislatura viu crescer de 4 para 16 o número de emendas constitucionais aprovadas. Essas alterações do texto constitucional veicularam regras como as de desestatização, as reformas administrativa e previdenciária, bem como a emenda da reeleição.

A intensa demanda por reformas constitucionais, a quantidade elevada de medidas provisórias reeditadas (gráfico da Figura 7, abaixo), e a aplicação da cédula única parecem responder pela formatação do processo decisório de vetos e consequentemente da configuração dessa agenda. Esse cenário favorece o argumento de que o modo anômalo de apreciação dos vetos não seria mera inércia, mas uma necessidade da agenda concreta, em face de demandas com tendência a se tornarem maiores que o calendário. Embora esse argumento não elimine fatores aqui não mensurados, como os interesses por trás desse descompasso, ele não pode ser ignorado. 
Figura 7: Gráfico do efeito das reedições de medidas provisórias sobre as sessões de vetos

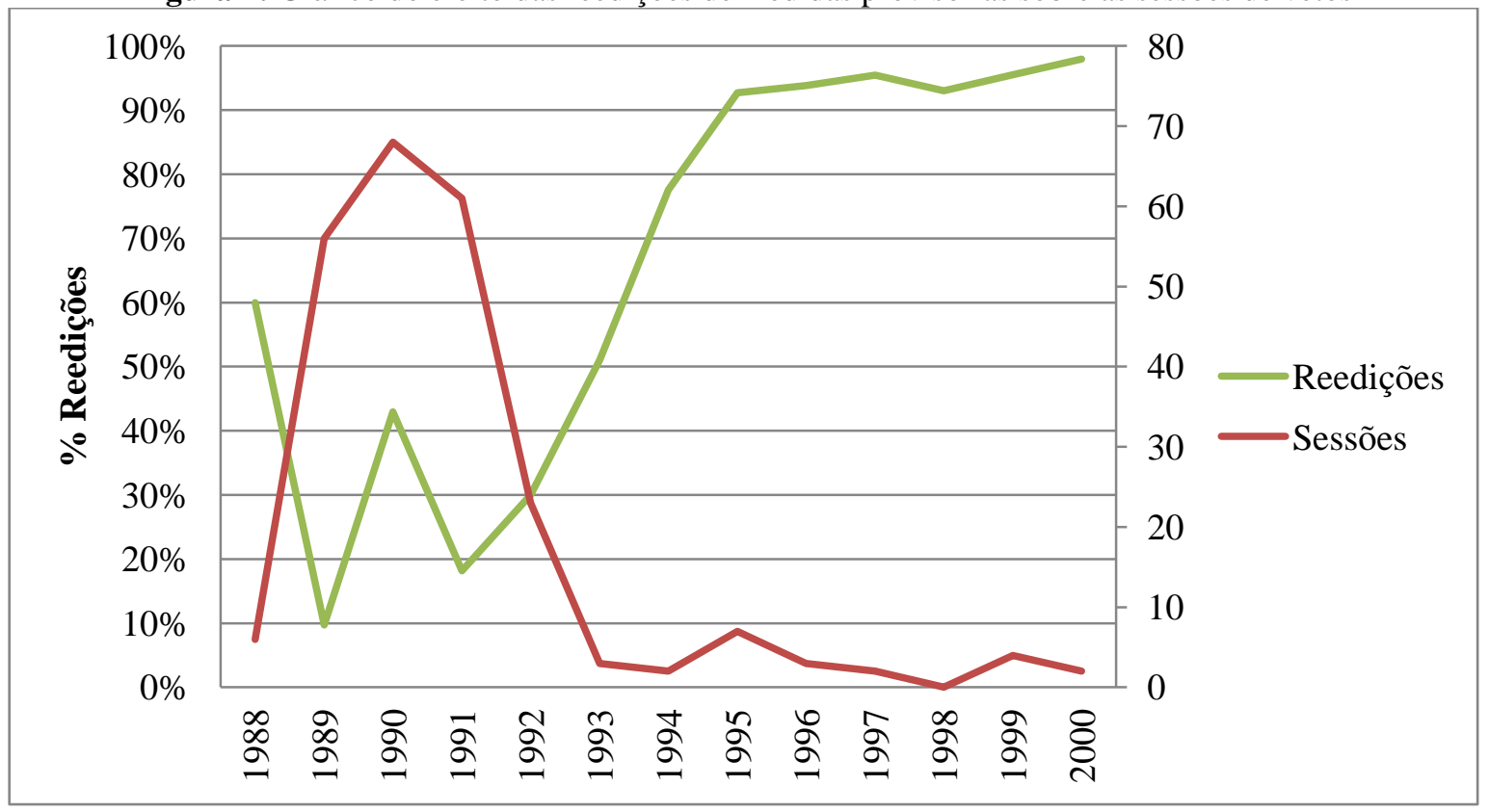

Fonte dos dados brutos: Sistemas de Informação do Senado Federal e da Câmara dos Deputados, Diário do Senado Federal e do Congresso Nacional; Relatório Anual da Presidência do Senado Federal; Lamounier, 2003 (p.133), sobre reedições.

Nota:

- Para o número de sessões foram consideradas as sessões convocadas com vetos em pauta, e não somente as efetivas.

Como antecipado no item anterior, o procedimento de reedição de medidas provisórias parece ter tido um efeito maior sobre a agenda de sessões conjuntas do que o veto. O texto original da Constituição de 1988 remetia a apreciação da medida provisória à sessão conjunta, e o emprego crescente de reedições veio acompanhado da prática de não decisão do Congresso sobre medidas provisórias. O gráfico da Figura 7 retrata uma relação forte da redução de sessões ao mesmo tempo em que as reedições se tornaram intensas.

Na realidade, o comportamento do Congresso para com as medidas provisórias reeditadas assemelha-se ao adotado para os vetos, dado que a inércia representada pela não apreciação de medidas provisórias em seu prazo de vigência na época, de 30 dias, combinada à prática de reedição, assemelha-se à prática de não se apreciarem vetos no prazo constitucional, o que já vinha ocorrendo antes mesmo da inflexão percebida no gráfico. Figueiredo e Limongi (2006) concluem desse modo para a medida provisória, enquanto o presente estudo o faz para o veto. 
Esse fator atesta que a relevância da arena do veto para o sistema político já era reduzida nos primeiros momentos da vida constitucional. Andava a reboque da agenda das medidas provisórias. Ao mesmo tempo, surge a nítida tendência de não decisão do Legislativo, aparentemente em favor de um processo decisório conjugado com o Executivo, em desfavor de uma noção de separação dos poderes, e em favor de certa noção de governabilidade. Isso vale tanto para o processo decisório de medidas provisórias quanto para o de vetos, com as distinções que aqui se fazem.

A 50a Legislatura transferiu 125 vetos para a legislatura seguinte, tendo resolvido 76 vetos, o que significou uma elevação considerável do estoque, seguida de uma redução igualmente marcante de sessões conjuntas. Embora a média anual de vetos tenha sido reduzida, de 55 para 38, não houve um maior rendimento deliberativo de vetos.

\subsubsection{1 ${ }^{\text {a }}$ Legislatura (1999-2002): Presidências do Congresso de Antônio Carlos Magalhães (PFL) e Ramez Tebet (PMDB) - Presidência do Presidente da República Fernando Henrique Cardoso (PSDB) (FHC II)}

Em 11 de setembro de 2001, foi publicada no Diário Oficial da União a Emenda à Constituição $n^{\circ}$ 32, de 2001 (BRASIL, 2001), que alterou as disposições do art. 62 da Constituição Federal (BRASIL, 1988), estabelecendo um novo paradigma para a edição e tramitação das medidas provisórias, vedando a possibilidade de reedição. A mudança mais significativa para a agenda das sessões conjuntas foi que, a partir de então, as medidas provisórias passaram a tramitar em casas separadas.

Pereira, Power e Rennó (2008) concluem que o principal efeito negativo da reforma foi o trancamento da pauta, denominado pelos autores de overriding of the agenda ou "agenda prioritária”, contribuindo para a argumentação de que o espaço da agenda concreta é espaço de poder, pois toca o cerne da reatividade legislativa à ação executiva sobre a legislação. No contexto de uma agenda presa, de um Executivo iniciador de legislação, não restaria espaço de expressão concreta de poder a um Poder Legislativo que não reagisse de algum modo. 
Assim, embora a alteração da regra de medidas provisórias tenha tido efeito imediato de liberar a agenda do Congresso em suas sessões conjuntas, deslocou o esforço de agenda para o cenário de cada uma das Casas legislativas, com efeitos inclusive sobre a apreciação de vetos, tanto sob o ponto de vista do conteúdo quanto do tempo, tornando as sessões conjuntas ainda mais indesejáveis.

O processo decisório de veto, descrito na seção anterior, ganha a nova característica de inexistência de medidas provisórias nas pautas das sessões conjuntas. Considerar-se-ia, de início, que essa "liberação da pauta” oportunizasse mais deliberações sobre os vetos. Mas o modelo existente, consolidado na $50^{\text {a }}$ Legislatura, reafirma-se na $51^{\text {a }}$, quando foram realizadas apenas 6 sessões conjuntas com vetos pautados, 5 delas efetivas. Nesse curto espaço de tempo, porém, resolveram-se 142 vetos, sendo 54 deles em uma única sessão.

Essa sessão, realizada em 15 de setembro de 1999 (BRASIL, 15/09/1999), durou menos de 3 horas e resultou na manutenção de 299 dispositivos vetados, distribuídos em 54 vetos, numa média de cerca de 29 segundos para cada votação, incluídos os tempos de debate.

A agenda de reformas constitucionais permaneceu intensa, atingindo o patamar de 19 emendas nessa legislatura, as quais incluíam alterações como duas prorrogações da contribuição provisória sobre movimentação ou transmissão de valores e de créditos e direitos de natureza financeira - CPMF, desvinculação de receitas da União - DRU, a já referida alteração do escopo normativo das medidas provisórias, entre outras.

O patamar de sessões conjuntas deliberativas caiu de uma média anual de 78 sessões na $48^{\mathrm{a}}$ para 15 na $51^{\mathrm{a}}$ Legislatura, e as sessões com vetos pautados tiveram um decréscimo ainda maior (gráfico da Figura 8, abaixo). Nos dois últimos anos dessa Legislatura não houve sessões de vetos. 
Figura 8: Gráfico da média de sessões conjuntas deliberativas, com vetos e efetivas $48^{\mathrm{a}}-51^{\mathrm{a}}$ Legislaturas

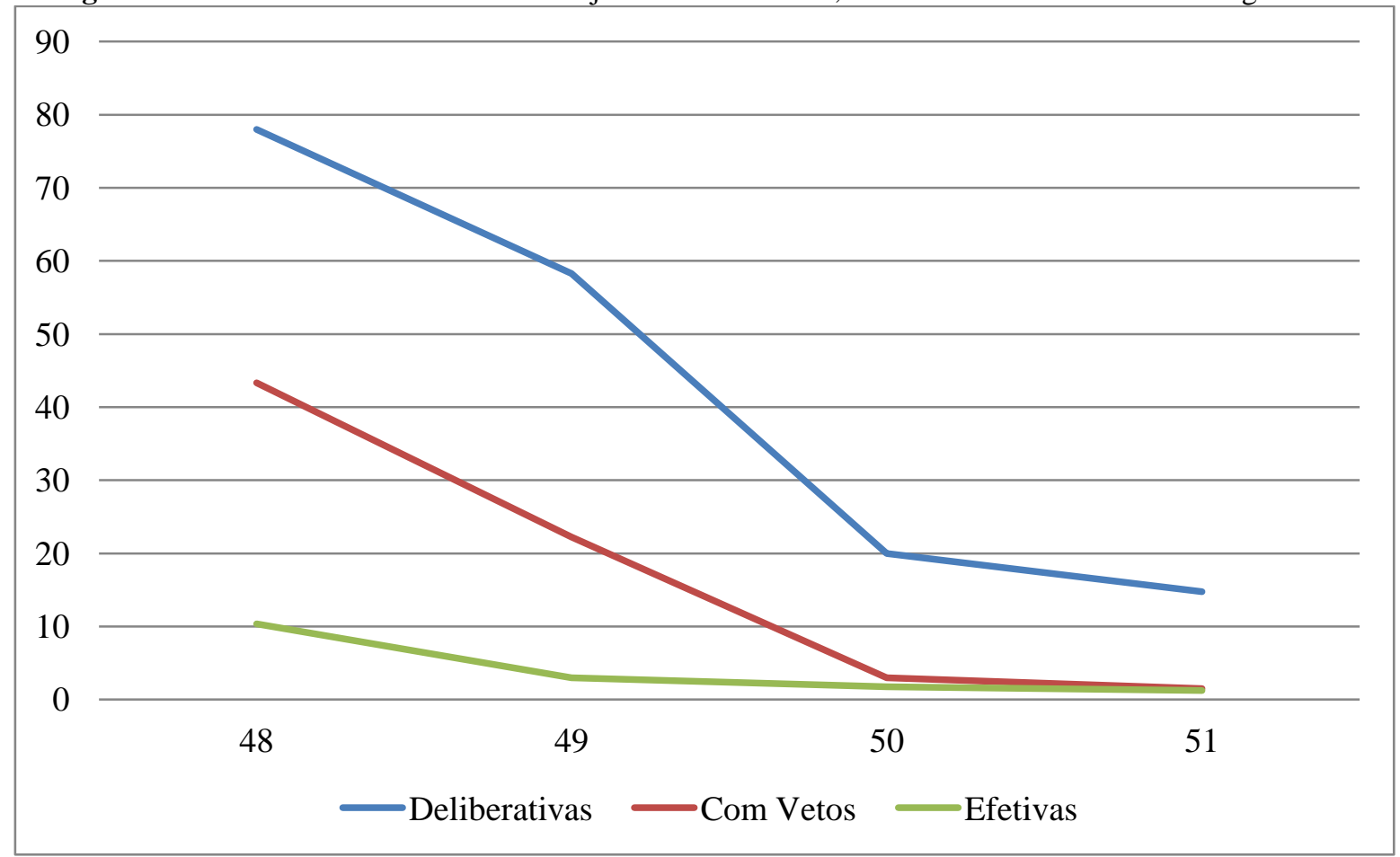

Fonte dos dados brutos: Sistemas de Informação do Senado Federal e da Câmara dos Deputados, Diário do Senado Federal e do Congresso Nacional; Relatório Anual da Presidência do Senado Federal.

Registra-se nessa legislatura o primeiro caso, pós 1988, de Presidente da República reeleito. Nas eleições de 2002 foi eleito Luiz Inácio Lula da Silva, representante do Partido dos Trabalhadores - PT, com uma agenda substantiva aparentemente diversa daquela praticada por Fernando Henrique Cardoso em seus dois mandatos, mais voltada para a agenda social, se bem que com a promessa de manutenção das bases conquistadas no campo econômico.

A $51^{\text {a }}$ Legislatura realizou apenas 5 sessões efetivas de vetos, resolveu sobre 142 deles e transferiu para a 52a Legislatura 133 vetos, o maior estoque transferido até então. O gráfico da Figura 9 a seguir registra a evolução do estoque. 
Figura 9: Gráfico de estoques transferidos à legislatura seguinte $-48^{\mathrm{a}}-51^{\mathrm{a}}$ Legislaturas

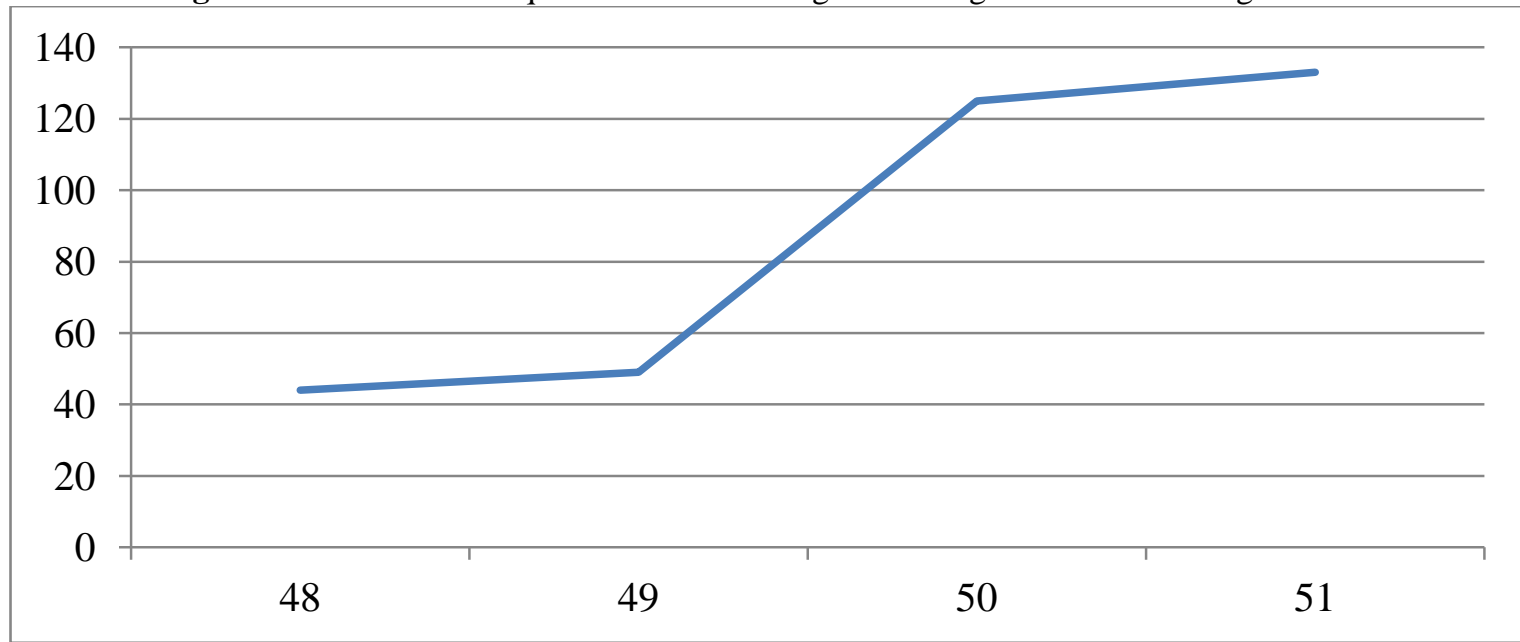

Fonte dos dados brutos: Sistemas de Informação do Senado Federal e da Câmara dos Deputados, Diário do Senado Federal e do Congresso Nacional; Relatório Anual da Presidência do Senado Federal.

O alto rendimento do mecanismo da cédula única de votações parece não ter sido suficiente para os estoques fossem reduzidos. Uma vez que a cédula é mecanismo de alto desempenho, só empregado sob condições de consenso prévio - mesmo porque não se trata de votação no sentido clássico - sua existência e não uso evidencia insegurança na apreciação dos vetos, que pode ser indiretamente mensurada pela elevação do estoque transferido. Trata-se de conflito transferido, vencido pelo tempo. A arena do veto já se apresenta como arena deserta, conforme os dados vão mostrando, legislatura a legislatura.

\subsubsection{2 ${ }^{\mathrm{a}}$ Legislatura (2003-2006): Presidências do Congresso de Renan Calheiros (PMDB) e José Sarney (PMDB) - Presidência da República Lula (PT) (Lula I).}

Acentua-se nessa legislatura outra prática não prevista nos regimentos ou na Constituição: o atraso da leitura do veto. O início da contagem do prazo constitucional de 30 dias dava-se na data da leitura da mensagem presidencial de veto, conforme o art. 104 do Regimento Comum:

“Art. 104. Comunicado o veto ao Presidente do Senado, este convocará sessão conjunta, a realizar-se dentro de 72 (setenta e duas) horas, para dar conhecimento da matéria ao 
Congresso Nacional, designação da Comissão Mista que deverá relatá-lo e estabelecimento do calendário de sua tramitação.

$\S 1^{\circ} \mathbf{O}$ prazo de que trata o $\S 4^{\circ}$ do art. 66 da Constituição será contado a partir da sessão convocada para conhecimento da matéria.” (BRASIL, 1970).

Além do fato de a sessão conjunta convocada em 72 horas raramente ocorrer, o atraso da leitura dos vetos publicados, depois de períodos de recesso parlamentar, passou a ser frequente a partir de 2004. Desse ponto em diante o atraso na leitura de alguns vetos alcançou uma média de 101 dias, alterando a contagem dos prazos respectivos desses vetos.

Quadro 3: Vetos lidos com atraso 2004-2012

\begin{tabular}{|c|c|c|c|}
\hline & Devida & Efetiva & $\begin{array}{c}\text { Atraso } \\
\text { (dias) }\end{array}$ \\
\hline 2004 & $15 / 2 / 04$ & $15 / 4 / 04$ & 60 \\
\hline 2005 & $15 / 2 / 05$ & $5 / 7 / 05$ & 140 \\
\hline 2006 & $3 / 2 / 06$ & $28 / 6 / 06$ & 145 \\
\hline 2007 & $3 / 2 / 07$ & $22 / 3 / 07$ & 47 \\
\hline 2008 & $3 / 2 / 08$ & $27 / 3 / 08$ & 53 \\
\hline 2009 & $3 / 2 / 09$ & $6 / 5 / 09$ & 92 \\
\hline 2010 & $3 / 2 / 10$ & $9 / 2 / 10$ & 6 \\
\hline 2011 & $3 / 2 / 11$ & $3 / 5 / 11$ & 89 \\
\hline 2012 & $3 / 2 / 12$ & $7 / 11 / 12$ & 278 \\
\hline
\end{tabular}

Fonte dos dados brutos: Sistemas de Informação do Senado Federal e da Câmara dos Deputados, Diário do Senado Federal e do Congresso Nacional; Relatório Anual da Presidência do Senado Federal.

Notas: a coluna "Devida” marca o início do ano legislativo em referência, enquanto a coluna "Efetiva” marca a data da leitura efetiva. Consideraram-se as leituras de vetos de anos anteriores que foram lidos somente no ano seguinte.

Esse recurso trouxe consequências até mesmo para a mensuração do tempo de tramitação do veto. Uma vez que a data de leitura é o marco oficial a partir do qual o tempo de tramitação inicia sua contagem, notam-se do Quadro 3 casos em que esse tempo estaria defasado em até 278 dias, quase 10 vezes o prazo constitucional.

A 52 ${ }^{\mathrm{a}}$ Legislatura, primeiro Governo Lula, herda da anterior não só o maior estoque até então, 133 vetos, mas também as demandas por reformas constitucionais, e a crescente utilização 
do recurso da medida provisória. São realizadas algumas delas: segunda reforma da previdência, a reforma do Judiciário, fim da verticalização de candidaturas eleitorais, além das prorrogações de CPMF e DRU.

Essa legislatura realizou apenas 3 sessões efetivas de vetos, de um total de 42 sessões conjuntas. Resolveu, entretanto, sobre 155 vetos, transferindo 131 à legislatura seguinte. Não houve sessões de vetos no primeiro e no último ano dessa legislatura, perfazendo 3 anos consecutivos (2001 a 2003) sem deliberações do Congresso sobre vetos. No início de 2004 o estoque atingiu o pico de 177 vetos pendentes.

Registra-se, ainda, a rejeição de dois vetos presidenciais, fenômeno raro para o período estudado. Os dois vetos tratavam dos planos de carreiras dos servidores do Poder Legislativo ${ }^{11}$. A essa altura, as rejeições a vetos tinham-se tornado raras, embora o ritmo de aposição de vetos tivesse atingido uma média anual de cerca de 40. A produção legal chegara a uma média de 210 leis por ano; logo, a proporção de vetos, totais ou parciais, atinge a marca de 1 a cada 5 leis promulgadas.

À parte a prática de leitura atrasada de vetos, não se verificam adaptações ou inovações procedimentais no processo decisório de vetos. A 52a Legislatura reforça o modelo decisório episódico, o que já permite antever o abandono do veto como local de conflito entre Executivo e Legislativo.

\subsubsection{3 ${ }^{\text {a }}$ Legislatura (2007-2010): Presidências do Congresso de Renan Calheiros ${ }^{12}$, Garibaldi Alves Filho (PMDB) e José Sarney (PMDB) - Presidência da República de Lula (PT) (Lula II).}

Na sessão de 9 de fevereiro de 2010 (BRASIL, 09/02/2010), pela primeira vez, um veto foi apreciado sob regime de urgência: Veto $n^{\circ}$ 7, de 2010 (aposto ao PLN 46/2010 - Lei

\footnotetext{
${ }^{11}$ Ver o Apêndice, ao final do presente texto, para um maior detalhamento de todos os casos de vetos rejeitados.

${ }^{12}$ Mandato renunciado após uma série de denúncias.
} 
Orçamentária anual de 2010 - na parte referente a obras da Petrobras). A mensagem respectiva havia sido publicada em 27 de janeiro de 2010, e foi incluída na pauta da sessão de 10 de fevereiro. Na data, havia vinte vetos sequer lidos, 14 deles do ano anterior.

O veto foi lido e imediatamente foi aprovado um requerimento de urgência, nos termos do art. 155 do Regimento Interno da Câmara dos Deputados (BRASIL, 1989), utilizado para votar matéria de relevante e inadiável interesse nacional, cujo primeiro signatário era a líder o Governo no Congresso Nacional, Senadora Ideli Salvatti, aprovado em votação simbólica.

Repita-se que, assim como ocorreu quanto à prejudicialidade, a atração do instituto da urgência regimental para a tramitação do veto é consequência da interpretação do veto como proposição, e é também consequência da situação gerada pela omissão deliberativa. Tendo em vista o permanente estoque pendente de deliberação, a votação de um veto novo com precedência sobre vetos anteriores, por óbvio, afrontaria a própria noção de trancamento de pauta, contida no texto constitucional. O desejo manifesto da maioria, na ocasião, de manter os vetos presidenciais referidos, foi mola propulsora da aplicação de norma regimental de urgência ao veto, cujo rito de tramitação é de plano constitucional.

Assinale-se que se tratava de ano das eleições gerais em que esteve em jogo a continuidade do Partido dos Trabalhadores na Presidência da República, e a tentativa de retorno do grupo político anterior, o Partido da Social Democracia Brasileira - PSDB. Os vetos tratados naquela sessão versavam sobre a paralisação de obras do complexo petroquímico da Petrobras no Rio de Janeiro. Dois pontos merecem nota. O primeiro é o esforço de agendamento do referido veto, e a formação de uma maioria para mantê-lo. O segundo diz reforça o tipo de "conflito" manifestado na arena do veto, já que não seria razoável supor que a movimentação da maioria para manter um veto tenha as mesmas causas e efeitos que o movimento de rejeitar.

Na mesma sessão, verifica-se outra inovação procedimental na apreciação de vetos: a distinção entre dois tipos de quórum em sessões de vetos, o da presença anunciada pela Presidência, no início da sessão, e aquele aferido nas listas de votação das urnas. Questões de ordem levantadas pela oposição atacaram a evidente falta de Senadores em número exigido pelo art. 47 da Constituição Federal (BRASIL, 1988), litteris: 
“Art. 47. Salvo disposição constitucional em contrário, as deliberações de cada Casa e de suas Comissões serão tomadas por maioria dos votos, presente a maioria absoluta de seus membros.” (negritos nossos)

O contra-argumento era de que somente após abertas as urnas e apuradas as cédulas da Câmara dos Deputados, seria possível aferir a necessidade de abrir as urnas do Senado. Esse raciocínio emprega a interpretação do art. 43 e seus parágrafos, do Regimento Comum (BRASIL, 1970), combinados com o art. 66, §4 da Constituição Federal (BRASIL, 1988):

“Art. 43. Nas deliberações, os votos da Câmara dos Deputados e do Senado Federal serão sempre computados separadamente.

$\S 1^{\circ} \mathrm{O}$ voto contrário de uma das Casas importará a rejeição da matéria.

$\S 2^{\circ}$ A votação começará pela Câmara dos Deputados. Tratando-se, porém, [de proposta de emenda à Constituição e] de projeto de lei vetado, de iniciativa de Senadores, a votação começará pelo Senado.” (BRASIL, 1970) (negritos nossos)

e

“Art. 66.

$\S 4^{\circ} \mathrm{O}$ veto será apreciado em sessão conjunta, dentro de trinta dias a contar de seu recebimento, só podendo ser rejeitado pelo voto da maioria absoluta dos Deputados e Senadores.” (BRASIL, 1988) (negritos nossos)

Pela combinação dos dispositivos acima um veto somente pode ser rejeitado se o for em ambas as Casas. Se, ao apurar os vetos dos Deputados, houver sua manutenção, ou mais bem posto, sua não rejeição, a derrubada já não mais é alcançável, razão pela qual não haveria motivos para abrir as urnas do Senado. O mesmo ocorre no sentido oposto (mantido no Senado não vai à Câmara), quando as matérias vetadas são de iniciativa do Senado ${ }^{13}$.

Na ocasião, as urnas referentes aos votos dos deputados foram abertas e, tendo sido o veto mantido, não foram apuradas as cédulas dos senadores. As urnas do Senado permaneceram lacradas. Havia nelas apenas 26 votos de Senadores, conforme listas de votação publicada (DCN de 10/2/2010), apesar da presença anunciada, no início da sessão, de 65 Senadores na Casa. Esclareça-se que a apuração dos votos por cédula ocorria, invariavelmente, depois de encerrada a sessão conjunta, como já se expôs, sob a supervisão de uma comissão apuradora, formada por parlamentares indicados pelas lideranças, que assinavam a ata de apuração e garantiam a lisura do processo.

\footnotetext{
${ }^{13}$ Ver item 2.10 no Apêndice ao texto, para detalhes sobre os vetos mútuos.
} 
Essa nova regra deliberativa lança mão da característica especial da sessão conjunta, em que deputados e senadores comparecem ao mesmo plenário, deliberam sobre a mesma pauta, mas sujeitos a regras regimentais separadas de votação, liderança e quórum. Some-se a isso o já especificado instituto de subsidiariedade regimental, e ver-se-á que também as regras constitucionais relativas a quórum tiverem sua leitura ajustadas às intenções de uma maioria que se viu diante de dificuldades em apreciar o veto.

Pode-se concluir até mesmo que a apreciação de vetos, tanto para rejeitá-lo, quanto para mantê-lo, como foi esse caso, adquire um caráter fortemente episódico e excêntrico, em que um caso dificilmente auxilia na previsão do próximo.

A 53ª Legislatura realizou apenas cinco sessões efetivas de veto para resolver sobre 208 deles. Transferiu um estoque de 130 vetos à Legislatura seguinte. Reafirma-se a tendência de sessões conjuntas raras e ainda mais raras sessões de vetos.

Consolida-se uma lógica segundo a qual os anos de maior rendimento legislativo por sessão apresentam em comum o emprego da cédula e a manutenção de todos os vetos apreciados, conforme se vê da Tabela 1.

Tabela 1: Sessões: 1988-2014 - Resolução de Vetos - Rendimentos e Métodos - $48^{\mathrm{a}}$ a $53^{\mathrm{a}}$ Legislaturas

\begin{tabular}{c|r|r|r|r|r}
\hline Ano & $\begin{array}{c}\text { Vetos } \\
\text { Resolvidos }\end{array}$ & $\begin{array}{c}\text { Vetos } \\
\text { Mantidos }\end{array}$ & $\mathbf{N}^{\mathbf{0}}$ de Sessões & $\begin{array}{c}\text { (médias anuais) } \\
\text { Rendimento } \\
\text { (vetos/sessão) }\end{array}$ & $\begin{array}{c}\text { Metodologia } \\
\text { de Votação }\end{array}$ \\
\hline $48^{\mathrm{a}}$ & 81 & 67 & 31 & 2,92 & Painel \\
\hline $49^{\mathrm{a}}$ & 215 & 208 & 26 & 24,39 & Painel \\
\hline $50^{\mathrm{a}}$ & 76 & 74 & 7 & 10,00 & Cédula \\
\hline $51^{\mathrm{a}}$ & 142 & 141 & 5 & 23,75 & Cédula \\
\hline $52^{\mathrm{a}}$ & 155 & 153 & 3 & 73,25 & Cédula \\
\hline $53^{\mathrm{a}}$ & 208 & 208 & 5 & 34,83 & Cédula \\
\hline
\end{tabular}

Fonte: Sistemas de Informação do Senado Federal e da Câmara dos Deputados, Diário do Senado Federal e do Congresso Nacional, Relatório Anual da Presidência do Senado Federal.

Essa evolução vista atesta a combinação de manutenção em massa de vetos, em raras sessões e por meio do uso de cédulas. A primeira legislatura que aplicou a cédula já realizou 
menos sessões. A partir de então, a redução brusca de sessões faz o rendimento se elevar consideravelmente, mas esse ritmo foi garantido pela metodologia mais apropriada para a manutenção massiva de vetos. Assim, aparentemente, uma maioria que produza consenso para manter centenas de vetos de uma só vez, poderia produzir os mais variados arranjos regimentais para tratar do assunto, como foi o caso da prejudicialidade, da urgência regimental e da contagem diferenciada de quórum.

\subsubsection{Legislatura (2011-2014): Presidências do Congresso de José Sarney (PMDB) e Renan Calheiros (PMDB) - Presidência da República de Dilma Rousseff (PT).}

Em 12 de julho de 2013 promulga-se a Resolução do Congresso Nacional n 1, de 2013 (BRASIL, 2013), apresentada e aprovada na mesma data, de autoria das Mesas da Câmara e do Senado, por iniciativa do Presidente da Câmara dos Deputados, Henrique Eduardo Alves, a qual estabeleceu as seguintes regras novas para a tramitação de vetos:

a) Mudança do marco inicial da contagem do prazo constitucional de 30 dias: da sessão convocada para “conhecimento” do veto para a data de protocolização da mensagem de veto junto à Presidência do Senado Federal;

b) Estabelecimento de calendário obrigatório próprio para apreciação de vetos, às terceiras terças-feiras de cada mês; e

c) Cláusula de incidência parcial da norma, restrita a vetos publicados a partir de $1^{\circ}$ de julho de 2013.

Essa última mudança produziu um efeito inusitado: todos os vetos publicados até o dia $1^{\circ}$ de julho de 2013 foram ignorados dali por diante, e a deliberação do Congresso deu-se de modo mensal, sem menção aos vetos que até ali trancavam a pauta. São 228 vetos que a partir de então deixaram de ser pautados, passando a constituir uma segunda categoria de vetos presidenciais, e fazendo surgir um “estoque congelado”.

Também em 2013 foi promulgada a Emenda constitucional $n^{0}$ 76, de 28 de novembro de 2013 (BRASIL, 2013a). Aprovada em um contexto de demanda social por mais transparência do 
Legislativo, notadamente no que tange as votações de cassação de mandato, a emenda suprimiu a votação secreta para a apreciação de vetos. Instaurada a dúvida quanto à metodologia de votação, especificamente quanto ao emprego da cédula, mecanismo consagrado nas votações secretas, prevaleceu a opção do uso do painel eletrônico para a sessão de vetos ocorrida em 10 de dezembro de 2013.

A promulgação da Resolução $n^{0}$ 1, de 2013 (BRASIL, 2013) é um evento incomum na evolução das normas e procedimentos do Congresso Nacional sobre vetos. Trata-se da primeira modificação formal do Regimento Comum desde 1970, e ilustra a efetividade da institucionalização formal de regras. Depois da promulgação dessa norma, que previa a realização de sessões de vetos mensais, o ritmo de apreciação do Congresso estabilizou-se e modificou a tendência verificada, da $51^{\text {a }}$ Legislatura até o ano de promulgação, terceiro ano da 54 a Legislatura. O Quadro 4 apoia a conclusão.

Quadro 4: Percentual de Resolução de Vetos $-48^{\mathrm{a}}$ à $54^{\mathrm{a}}$ Legislaturas

(médias anuais)

\begin{tabular}{|c|c|c|}
\hline Legislatura & $\begin{array}{c}\text { \% Resolução } \\
\text { Simples }\end{array}$ & $\begin{array}{c}\text { \% Resolução com } \\
\text { Estoque }\end{array}$ \\
\hline $48^{\mathrm{a}}$ & $66,8 \%$ & $68,1 \%$ \\
\hline $49^{\mathrm{a}}$ & $34,8 \%$ & $54,3 \%$ \\
\hline $50^{\mathrm{a}}$ & $9,5 \%$ & $17,3 \%$ \\
\hline $51^{\mathrm{a}}$ & $16,6 \%$ & $28,9 \%$ \\
\hline $52^{\mathrm{a}}$ & $4,1 \%$ & $19,5 \%$ \\
\hline $53^{\mathrm{a}}$ & $0,6 \%$ & $23,3 \%$ \\
\hline $54^{\mathrm{a}}$ & $36,1 \%$ & $7,2 \%$ \\
\hline
\end{tabular}

Fonte dos dados brutos: Sistemas de Informação do Senado Federal e da Câmara dos Deputados, Diário do Senado Federal e do Congresso Nacional; Relatório Anual da Presidência do Senado Federal.

Notas:

- A resolução simples considera apenas vetos da própria legislatura resolvidos por ela mesma. A resolução com estoques diz respeito aos vetos resolvidos, independentemente do ano de aposição do veto.

- A 48 ${ }^{\mathrm{a}}$ Legislatura inclui apenas 3 anos, em vista da promulgação da constituição em 1988 e eleições do Legislativo em 1990.

Depois da promulgação da Resolução 1 de 2013, a capacidade de resolução simples, sempre abaixo dos 20\%, chegou ao maior percentual desde a 49a Legislatura. Ao mesmo tempo a resolução com estoques despencou para 7,2\%, consequência do congelamento do estoque existente na data de promulgação da norma, produzido pelo art. $2^{\circ}$, que o aplicava tão somente a vetos publicados a partir da promulgação. 
Essa distinção é relevante para confirmar o valor da legislatura como unidade de agregação dos dados. A presidência de Renan Calheiros (2013-2014) viu-se diante de um passivo deliberativo que somente poderia ser debelado por meio do emprego intenso do recurso da cédula, que, como já exposto, depende de consenso, em um esforço deliberativo adicional causado basicamente pela mora legislativa de outras presidências.

Sem adentrar a discussão acerca da constitucionalidade da norma regimental inovadora, a $54^{\mathrm{a}}$ Legislatura testemunha um caso de alteração que impacta concretamente o exercício do poder de agenda do Congresso, algo que nem mesmo a cédula foi capaz de produzir. A diferença entre o instituto estabelecido por processo legislativo e aquele construído pelo uso, nesse caso, é nítido, sendo que a norma geral parece causar um efeito mais visível nos comportamentos, ao menos no que tange a escolha por votar estoques antigos por parte do Congresso. 


\section{3 - METODOLOGIA}

A matéria prima da metodologia desenvolvida é a informação legislativa, um conjunto heterogêneo de dados que se formam em torno do processo legislativo, que é um processo institucionalmente delineado, animado pela ação dinâmica dos representantes ao longo de suas fases, na consecução de interesses heterogêneos. A principal ferramenta utilizada na prospecção dessa informação legislativa foi a pesquisa documental em fontes primárias.

O processo institucionalmente delineado que se observa é o procedimento legislativo, que difere do processo legislativo em que este “[...] (bastante mais complexo) abrange o procedimento legislativo (iter legis), entendido como uma parte do processo que está sujeita a normas do ordenamento positivo” (OLIVETTI, 1998, p. 996). Para o objeto em análise - o processo decisório de vetos - abrem-se duas frentes de prospecção dos dados: as sessões conjuntas e os vetos como matéria legislativa.

O procedimento legislativo conta a história das decisões políticas transformadas em atos jurídicos por meio de ações rituais, praticadas nos locais de expressão do poder instituído, por meio de declarações e atos concretos, cujo efeito combinado produz registros que farão parte da documentação que formaliza e legitima a transformação, armazenando dados que permitem recontar aquela história.

\subsection{Obtenção dos dados}

As informações legislativas referentes às sessões conjuntas foram prospectadas nos Diários do Senado Federal, da Câmara dos Deputados e do Congresso Nacional ${ }^{14}$. Esses documentos oficiais são formados a partir da combinação das notas taquigráficas referentes às sessões, com expedientes lidos e mencionados durante as sessões. As ações e decisões referentes

\footnotetext{
${ }^{14}$ Documentos disponibilizados nos sítios das duas Casas e do Congresso Nacional.
} 
às matérias legislativas são registradas em fichas de tramitação individuais respectivas, formando um banco de dados de informações predominantemente digitais.

Foi pesquisado, de modo complementar, o Relatório Anual da Presidência do Senado Federal. Trata-se de sumário estatístico anual que registra os quantitativos das matérias deliberadas pelo Senado Federal e pelo Congresso Nacional. Os diários e relatórios apreendem o que se poderia chamar de processo legislativo oficial, composto de discursos, debates e decisões, cujos resultados são consolidados em uma ata, a partir da qual se faz prova das decisões e opiniões resultantes da ação legislativa.

Os dados obtidos nas “atas das sessões de veto” foram incluídos em uma planilha, referente a todas as 263 sessões conjuntas ocorridas de 1988 a 2014, em que se tenham pautado vetos, e foram agregados por data da sessão realizada, em linhas, e nas seguintes colunas: ano, data, procedimento adotado, quantidade de vetos da pauta, resultado da sessão, observações e presidência do Congresso na data da sessão (Figura 1).

Figura 10: Captura de tela ilustrando parte da planilha das sessões de apreciação de veto.

\begin{tabular}{|c|c|c|c|c|c|c|c|}
\hline 4 & A & $\mathrm{B}$ & C & $\mathrm{D}$ & $\mathrm{E}$ & $\mathrm{F}$ & G \\
\hline 1 & ANO & DATA & PROCEDIMENTO & n. de itens & Resultado & OBSERVAÇŌES & PRESIDÊNCIA CN \\
\hline 2 & 1988 & $30 / 11 / 1988$ & Cédulas & 4 itens & 4 Vetos mantidos & & Sen. Nelson Carneiro \\
\hline 3 & 1988 & 29/11/1988 & Painel Eletrônico & 4 itens & Falta de quorum. & & Sen. Nelson Cameiro \\
\hline 4 & 1988 & $23 / 11 / 1988$ & Painel Eletrônico & 4 itens & Falta de quorum. & & Sen. Nelson Cameiro \\
\hline 5 & 1988 & $22 / 11 / 1988$ & Painel Eletrônico & 4 itens & Falta de quorum. & & Sen. Nelson Cameiro \\
\hline 6 & 1988 & $16 / 11 / 1988$ & Painel Eletrônico & 4 itens & Falta de quorum. & & Sen. Nelson Cameiro \\
\hline 7 & 1988 & $09 / 11 / 1988$ & Painel Eletrônico & 4 itens & Falta de quorum. & & Sen. Nelson Cameiro \\
\hline 8 & 1989 & $13 / 12 / 1989$ & Painel Eletrônico & 5 itens & 5 Vetos mantidos. & Demais itens adiados & Sen. Nelson Cameiro \\
\hline 9 & 1989 & $12 / 12 / 1989$ & Painel Eletrônico & 5 itens & Votação adiada. & +3 MPVs na pauta -2 aprovadas. & Sen. Nelson Carneiro \\
\hline 10 & 1989 & $07 / 12 / 1989$ & Painel Eletrônico & 4 itens & Votação adiada. & & Sen. Nelson Cameiro \\
\hline 11 & 1989 & $06 / 12 / 1989$ & Painel Eletrônico & 5 itens & Falta de quorum. & & Sen. Nelson Cameiro \\
\hline 12 & 1989 & $05 / 12 / 1989$ & Painel Eletrônico & 4 itens & Falta de quorum. & & Sen. Nelson Cameiro \\
\hline 13 & 1989 & $30 / 11 / 1989$ & Painel Eletrônico & 1 item & Falta de quorum. & & Sen. Nelson Cameiro \\
\hline 14 & 1989 & 28/11/1989 & Painel Eletrônico & 1 item & 1 veto mantido. & & Sen. Nelson Cameiro \\
\hline 15 & 1989 & $23 / 11 / 1989$ & Painel Eletrônico & 1 item & Falta de quorum. & & Sen. Nelson Cameiro \\
\hline 16 & 1989 & $22 / 11 / 1989$ & Painel Eletrônico & 1 item & Falta de quorum. & + 1 PLN na pauta. & Sen. Nelson Carneiro \\
\hline 17 & 1989 & $21 / 11 / 1989$ & Painel Eletrônico & 1 item & Falta de quorum. & - 1 PLN na pauta. & Sen. Nelson Cameiro \\
\hline 18 & 1989 & $26 / 10 / 1989$ & Cédulas & 3 itens & $\begin{array}{l}1 \text { Veto rejeitado e } 2 \\
\text { Vetos mantidos. }\end{array}$ & $t$ & Sen. Nelson Cameiro \\
\hline 19 & 1989 & $26 / 10 / 1989$ & Painel Eletrônico & 3 itens & \begin{tabular}{|l}
1 veto rejeitado \\
2 vetos mantidos
\end{tabular} & & Sen. Nelson Cameiro \\
\hline 20 & 1989 & $25 / 10 / 1989$ & Painel Eletrônico & 4 itens & 1 Veto mantido. & Demais itens adiados por falta de & Sen. Nelson Cameiro \\
\hline 21 & 1989 & $24 / 10 / 1989$ & Painel Eletrônico & 4 itens & Falta de quorum. & + 4 PLNs na pauta. & Sen. Nelson Cameiro \\
\hline 22 & 1989 & $18 / 10 / 1989$ & Painel Eletrônico & 5 itens & 1 veto mantido. & Demais itens adiados por falta de & Sen. Nelson Cameiro \\
\hline 23 & 1989 & $14 / 09 / 1989$ & Painel Eletrônico & 1 item & 1 Veto mantido. & & Sen. Nelson Cameiro \\
\hline 24 & *1 $\begin{array}{c}1989 \\
\text { Tabela Fina }\end{array}$ & $\begin{array}{l}13 / 09 / 1989 \\
\text { Oontagem 1968-2014 }\end{array}$ & Painel Eletrônico & 3 itens & 2 vetos mantidos. & & Sen. Nelson Cameiro \\
\hline
\end{tabular}

Fonte: elaboração própria. 
A pesquisa das sessões e das fichas de tramitação dos vetos foi realizada quase que exclusivamente a partir dos sítios do Senado Federal e do Congresso Nacional na Internet. Assim, pode-se dizer que se trata de pesquisa documental em fonte primária digital. As lacunas existentes foram preenchidas a partir do acervo físico de diários oficiais arquivados na Secretaria Legislativa do Congresso Nacional ${ }^{15}$.

Com base nas atas das sessões de veto, foram produzidos 27 documentos nos quais se reproduziram as narrativas desses 263 eventos, pontuando, ano a ano, os incidentes, criações e adaptações procedimentais que se incluíram na apreciação dos vetos. Objetivou-se com essas “histórias” obter um extrato para posterior pesquisa dos movimentos de cada legislatura (Figura 2).

Figura 11: Captura de tela ilustrando um dos documentos descrevendo o "histórico" de apreciação de vetos.

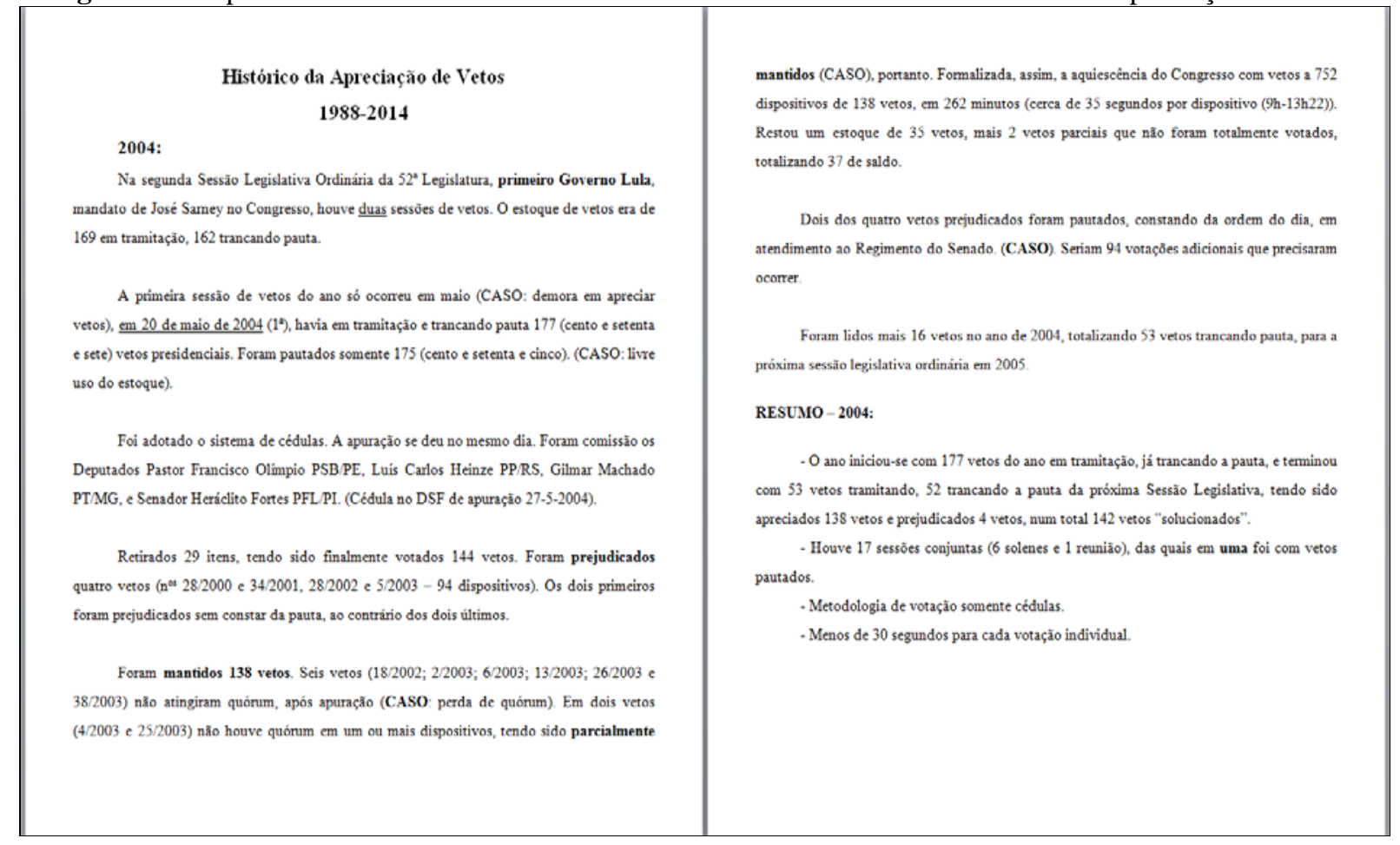

Fonte: elaboração própria

\footnotetext{
${ }^{15}$ Unidade subordinada à Secretaria-Geral da Mesa do Senado Federal, responsável pelas sessões conjuntas.
} 
Das fichas individuais de tramitação foram extraídos os dados referentes a cada veto, que foram incluídos em uma planilha, referente aos 1.160 vetos, qualificados por 24 colunas com as diversas variáveis consideradas relevantes, tais como: tipo do veto (total parcial), presidente da República a vetar, autor da matéria vetada, tempo de tramitação, assunto da matéria vetada, resultado final da apreciação, entre outras (Figura 3).

Figura 12: Captura de tela ilustrando a planilha dos vetos.

\begin{tabular}{|c|c|c|c|c|c|c|c|c|c|c|c|c|c|c|c|c|c|}
\hline & $\overline{A A}$ & 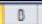 & $\bar{c}$ & $\bar{D}$ & $\bar{c}$ & $\bar{f}$ & $\bar{G}$ & $\overline{\mathrm{H}}$ & $\overline{1}$ & $\bar{J}$ & $\overline{\mathrm{k}}$ & $\overline{\mathrm{L}}$ & $\bar{M}$ & $\overline{\mathrm{N}}$ & $\overline{0}$ & $\overline{p p}$ & 0 \\
\hline 1 & $N^{\prime}$ do reto/ASG & Ano & Legislatura & Presidente & Tipo & Disposithros & Tipo & $\mathrm{x}$ & AUTOR & Ano & $\mathrm{NCD}$ & Ano CD & Protocollizacia & Leiturn & Prazo Comissìo & Prazo Congresso & Comiss \\
\hline 1071 & 51 & 2012 & 54 & Dilma Roussef & Parcial & 1 & PLC & 127 & Presidenta da Repüblita & 2012 & 4.371 & 2012 & 02012013 & 06032013 & $2603 / 2013$ & $05: 04 / 2013$ & Nāo \\
\hline 1072 & 52 & 2012 & 54 & Dilma Roussef & Parcial & 8 & PLC & 129 & Tribunal de Contes da Ueisio & 2012 & 1.863 & 2011 & 02012013 & 06032013 & $2603 / 2013$ & 05042013 & Năo \\
\hline 1073 & 53 & 2012 & 54 & Dima Roussef & Parcial & 1 & PLC & 130 & MESA DA C.MMARA DOS DA & 2012 & 2.167 & 2011 & 02012013 & 06032013 & $2603 / 2013$ & 05042013 & $\mathrm{~N} 30$ \\
\hline 1074 & 1 & 2013 & 54 & Dilma Roussef & Parcial & s & PLV & 26 & COMISSAOMISTA & 2012 & 26 & 2012 & 10012013 & $0603 / 2013$ & $2603 / 2013$ & $05: 04 / 2013$ & Năo \\
\hline 1075[ & 2 & 2013 & 54 & Dilma Roussef & Total & 1 & PLC & 87 & DEPUTADO & 2011 & 5982 & 2009 & 10012013 & 06032013 & $2603 / 2013$ & 05042013 & Näo \\
\hline 1076 & 3 & 2013 & 54 & Dilma Roussef & Total & $\dot{1}$ & PIC & 172 & DEPUTADO & 2009 & 6.070 & 2005 & 14012013 & 06032013 & $2603 / 2013$ & $0504 / 2013$ & $\mathrm{Nan}$ \\
\hline 1077 & 4 & 2013 & 94 & Dilma Roussef & Parctal & 11 & PLV & 30 & COMISSAO MISTA & 2012 & 30 & 2012 & 1401/2013 & 06032013 & $2603 / 2013$ & $0500 / 2013$ & Não \\
\hline 1078 & 5 & 2013 & 54 & Dilma Roussef & Parcial & 4 & PLS & 229 & CSF & 1995 & 6.381 & 2005 & $1401 / 2013$ & 06032013 & $2603 / 2013$ & 05042013 & Năo \\
\hline 1079 & 6 & 2013 & 54 & Dilma Roussef & Parcial & 42 & PLV & 27 & 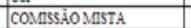 & 2012 & 27 & 2012 & 16012013 & 06032013 & $2603 / 2013$ & $05 / 04 / 2013$ & Nă \\
\hline 1080 & 7 & 2013 & 94 & Dilma Roussef & Parctal & 8 & PLS & i1) & SENADOR & 2007 & 3.92 & 2012 & $15,03 / 2013$ & $03 ; 07 / 2013$ & $2307 / 2013$ & 02082013 & Nảo \\
\hline 1081 & 8 & 2013 & 54 & Dilma Roussef & Parcial & 32 & PLV & 32 & COMSSSTOMSTA & 2012 & 32 & 2012 & 04042013 & 03072013 & $2307 / 2013$ & 02082013 & Năo \\
\hline 1082 & 9 & 2013 & 54 & Dilma Roussef & Parcial & 46 & PLV & 1 & COMISST̈O MISTA & 2013 & 1 & 2013 & 04042013 & $0307 / 2013$ & 23072013 & $0208 / 2013$ & Nă \\
\hline 1083 & 10 & 2013 & 54 & Dilma Roussef & Parceal & 2 & PLC & 200 & Presidente da Republica & 2009 & 2,395 & 2009 & $0904 / 2013$ & 03:07/2013 & $2307 / 2013$ & 02082013 & Näo \\
\hline 1084 & 11 & 2013 & 54 & Dilma Roussef & Total & $i$ & PLC & 119 & DEPUTADO & 2010 & 2.192 & 2003 & 25042013 & $0307 / 2013$ & $2307 / 2013$ & 02082013 & Năo \\
\hline 1085 & 12 & 2013 & 94 & Dilma Roussef & Parcial & 8 & PLV & 3 & COMISSSTO MSTA & 2013 & 3 & 2013 & $1505 / 2013$ & $0307 / 2013$ & $2307 / 2013$ & $0208 / 2013$ & Nào \\
\hline 1086 & 13 & 2013 & 54 & Dilma Rousseff & Parcenal & 1 & PLV & 4 & COMLSSIO MISTA & 2013 & 4 & 2013 & $1605 / 2013$ & $03,07 / 2013$ & $2307 / 2013$ & 02082013 & Năo \\
\hline 1087 & 14 & 2013 & 54 & Diluma Roussef & Parcial & 7 & PLC & 26 & Presidente da Ropüblica & 2012 & 7528 & 2006 & $2205 / 2013$ & $0307 / 2013$ & 23072013 & 02082013 & Năo \\
\hline 1088 & 15 & 2013 & 54 & Diman Roussef & \begin{tabular}{|l|} 
Parcial \\
\end{tabular} & 14 & PIV & 5 & COMISSAOOOMSTA & 2013 & 5 & 2013 & $2205 / 2013$ & $0307 / 2013$ & $2307 / 2013$ & 02082013 & Naso \\
\hline 1090 & 16 & 2013 & 54 & Dilma Roussef & Parcen & 21 & PLV & 9 & COMISSIO MISTA & 2013 & 9 & 2013 & 07062013 & $03,07 / 2013$ & $2307 / 2013$ & 02082013 & Näo \\
\hline 1090 & 17 & 2013 & 54 & Ditha Roussef & Pacial & 9 & PLV & 6 & COMISSIO MISTA & 2013 & 6 & 2013 & 07062013 & 03072013 & $23: 072013$ & 02082013 & Năo \\
\hline 1091 & 18 & 2013 & 54 & Dilma Roussef & Parcial & 1 & PLC & 102 & DEPUTADO & 2008 & 6.046 & 2005 & 07,062013 & $0307 / 2013$ & $2307 / 2013$ & 02082013 & $\mathrm{Nan}$ \\
\hline 1092 & 19 & 2013 & 54 & Dilma Roussef & Parcal & 1 & PLC & 132 & DEPUTADO & 2012 & 7.193 & 2010 & 24062013 & $03,07 / 2013$ & $0108 / 2013$ & 02082013 & Näo \\
\hline 1093 & 20 & 2013 & 54 & Ditho Roussef & Total & 1 & P.S & 56 & SENADOR & 2005 & 6104 & 2005 & 24062013 & $03: 072013$ & 010022013 & $0208 / 2013$ & Nลัง \\
\hline 1094 & 21 & 2013 & 54 & Dilma Roussef & \begin{tabular}{|l|} 
Parcial \\
\end{tabular} & 35 & PLV & 10 & COMMSST̈O MSTA & 2013 & 10 & 2013 & 24062013 & 03072013 & 01032013 & 02082013 & Nào \\
\hline 1095 & 22 & 2013 & 54 & Dilena Roussef & Parcent & 2 & PLV & 13 & COMLSSIO MISIA & 2013 & 13 & 2013 & $1107 / 2013$ & $1107 / 2013$ & 05082013 & 09082013 & Näo \\
\hline 1096 & 23 & 2013 & 54 & Dilma Roussef & Parial & 29 & PLV & 15 & COMSSSTO MMSTA & 2013 & 15 & 2013 & 11,072013 & $11: 072013$ & 05082013 & $0908 / 2013$ & Nั้ง \\
\hline 1097 & 24 & 2013 & 94 & Dilma Roussef & Parcial & 10 & PLS & 268 & SENADOR. & 2002 & 7.903 & 2006 & $1207 / 2013$ & $17 / 072013$ & 05082013 & 09082013 & Nå \\
\hline 1028 & 25) & 2013 & 94 & Dilma Roussef & Parcal & 1 & PLS & 240 & SENMDOR & 2013 & 288 & 2013 & $1807 / 2013$ & 01082013 & 16082013 & $1608 / 2013$ & Näo \\
\hline 1099 & 26 & 2013 & 54 & Dihn Roussef & Pacial & 85 & PLV & 17 & COMTSSTO MITA & 2013 & 17 & 2013 & 22072013 & 01,082013 & 20082013 & 20082013 & Nั้⿰丿 \\
\hline 1100 & 27 & 2013 & 54 & Dilma Roussef & Total & 1 & PLS & 198 & SENADOR. & 2007 & 200 & 2012 & $2907 / 2013$ & 01082013 & 20082013 & 27082013 & Não \\
\hline 1101 & 28 & 2013 & 34 & Dilma Roussef & Total & $i$ & PLS & 322 & SENADOR & 2008 & 6.127 & 2009 & 02082013 & 06082013 & 25082013 & 31082013 & Näo \\
\hline 1102 & 29 & 2013 & 54 & Dhitm Roussef & Parcial & 3 & PL.C & 39 & Presilemie dh Regrullitia & 2013 & 6886 & 2010 & 02082013 & 06082013 & 25082013 & $31 / 08 / 2013$ & $\frac{1}{\text { Nั้ }}$ \\
\hline 1103 & 30 & 2013 & 54 & Dilma Roussef & Total & 1 & PLS & 24 & SENADOR & 2009 & 5.619 & 2009 & 02082013 & 06082013 & 25082013 & 31082013 & Nāo \\
\hline 1104 & 31 & 2013 & 94 & Dilma Roussef & Total & $i$ & PLC & 83 & DEPUTADO & 2007 & 7320 & 2006 & 07082013 & 08082013 & 27082013 & 05092013 & Näo \\
\hline 1105 & 32 & 2013 & 54 & Dhima Roussef & \begin{tabular}{|c|} 
Parcial \\
\end{tabular} & 3 & PIC & 98 & DEPUTADO & 2011 & 4529 & 2004 & 08082013 & 08082013 & 270822013 & 0609,2013 & Nרัง \\
\hline 1106 & 33 & 2013 & 54 & Dilma Roussef & Parcial & 3 & PLC & 47 & Presidente da Repüblica & 2013 & 4.264 & 2012 & 04092013 & 04092013 & $23,09: 2013$ & $03 / 10 / 2013$ & Naso \\
\hline 1107 & 34 & 2013 & 54 & Dilma Roussef & Parcial & 2 & PLC & 60 & Presidente da Regublica & 2011 & 5.894 & 2009 & $0409 / 2013$ & $0409 / 2013$ & $2309 / 2013$ & 0311022013 & Náo \\
\hline 1108 & 35 & 2013 & 54 & Dhima Roussef & Pactial & 48 & PLC & 123 & Presilamiec is R-yidition & 2012 & 2205 & 2011 & 04092013 & 04092013 & 23092013 & $03 / 102013$ & Nั้ง \\
\hline 1109 & 36 & 2013 & 54 & Dilma Roussef & Total & $\frac{10}{1}$ & PLS & 612 & SENADOR & 1999 & 2.611 & 2003 & 12092013 & 13092013 & $02 / 102013$ & $11 / 10201313$ & $\mathrm{~N}_{\mathrm{a} 0}$ \\
\hline 1110 & 37 & 2013 & 54 & Dilma Roussef & Parcial & 1 & PLV & 20 & COMSOSlO MSTA & 2013 & 20 & 2013 & 12092013 & 13092013 & 02102013 & $11 / 102013$ & Não \\
\hline 1111 & 38 & 2013 & 54 & Dhima Ruussef & Total & 1 & PLS & 370 & SEVADOR & 2007 & 4042 & 2008 & 20,092013 & 24092013 & 13/102013 & 19102013 & Nă้ \\
\hline 1112 & 39 & 2013 & 54 & Dilma Roussef & Parcial & 8 & PLV & 18 & COMISSÄO MISTA & 2013 & 18 & 2013 & 26092013 & 26092013 & $15 / 10 / 2013$ & $25 / 102013$ & Năo \\
\hline 1113 & 40 & 2013 & 54 & Dilema Roussef & Parcial & 22 & PLV & 21 & CoMISST.10 MITA & 2013 & 21 & 2013 & 111102013 & 14102013 & $02 / 1 / 2013$ & $09 / 112013$ & Não \\
\hline 1114 & 41 & 2013 & 54 & Ditma Roussef & Parcial & 1 & PL.S & 294 & CSF & 2001 & 6405 & 2002 & $14 / 102013$ & $14 / 102013$ & $02 / 112013$ & $12 / 1 / 2013$ & Nล้ \\
\hline 1115 & 42 & 2013 & 54 & Dilma Roussef & Parcial & 2 & PLC & 40 & DEPUTADO & 2013 & 4.280 & 2003 & $17 / 102013$ & $21 / 102013$ & $09 / 1 / 2013$ & $15 / 11 / 2013$ & $\mathrm{Nă}$ \\
\hline 1116 & 43 & 2013 & 54 & Dilma Roussef & Parcial & 1 & PLC & 83 & DERUTADO & 2011 & 2.123 & 2007 & 177102013 & $21 / 102013$ & $09 / 112013$ & $15 / 11 / 2013$ & Não \\
\hline$\ldots$ & , n M̈atriz & Matrot & Todos & Resultà os Vetos & In & Aprectádo & Rejertados & +1 wotaç & 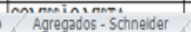 & Filuto & e Assunto & and & os de Anprectac & $d x t a$ & antes: 40 & 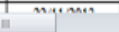 & , \\
\hline
\end{tabular}

Fonte: elaboração própria

Ressalte-se que o quantitativo total de vetos apostos não corresponde ao de vetos apreciados. Isso ocorre, porque alguns vetos foram desmembrados e apreciados em mais de um processo de votação, o que ocorreu 25 vezes em 17 vetos, de modo que o conjunto total de vetos apreciados é de 1.185. Para variáveis como autoria e tema das matérias vetadas, a matriz permaneceu sendo formada por 1.160 vetos, para evitar repetições, enquanto para as variáveis 
relacionadas à resolução dos vetos (votações ou declarações de prejudicialidade) empregou-se a planilha maior, para evitar o efeito contrário.

O cruzamento das informações dessas duas planilhas principais - sessões e vetos permitiu formar as unidades de análise, que são as deliberações da sessão conjunta e suas regras de procedimento, cujos resultados são as alterações do status legislativo do veto, sua eventual resolução. Em articulação com a base teórica, é essa a estrutura analítica da dissertação, por intermédio da qual se buscou responder as questões de pesquisa e testar as hipóteses aventadas.

Algumas justificações são pertinentes. A primeira diz respeito à contagem dos vetos parciais. Para cada veto parcial foram contabilizadas as partes efetivamente apreciadas. Assim, se um veto continha quatro partes vetadas, mas foi votado em painel eletrônico em uma única votação, as partes do veto, para efeito da presente análise, contaram um. Isto porque a contagem de parte a parte subverteria nossa observação da votação do veto.

A segunda justificação diz respeito ao tema da matéria vetada. Moya (2005) parte da classificação de Figueiredo e Limongi (1999), empregando quatro temas: administrativo, econômico, social e político, excluindo, porém, os temas orçamentários e homenagens. Optou-se por utilizar a classificação preconizada pelo atual sistema de informação legislativa do Senado Federal: administrativo, econômico, social, jurídico e honorífico. Essa escolha pareceu mais razoável por apresentar uma única fonte, caso fosse necessário sanar eventuais discrepâncias.

O recorte temporal compreende o período de 6 de outubro de 1988 a 31 de dezembro de 2014. Essa escolha deveu-se à instauração da ordem juspolítica nova, com a promulgação da Constituição Federal (BRASIL, 1988), ao que se seguiram seis legislaturas completas, além daquela responsável pelo poder constituinte originário. São 27 anos de um regime democrático eleitoral, sem interrupções, prestando-se à observação proveitosa do funcionamento das instituições políticas. Registram-se os mandatos de quatro presidentes da República eleitos diretamente, além de sete eleições para as duas Casas do Congresso Nacional.

Percebe-se, pela seleção das fontes, que as escolhas metodológicas priorizaram a observação da movimentação oficial de atores institucionais. Sabe-se que seu movimento não oficial ultrapassa as atas, o que indicaria a necessidade de outros métodos como a entrevista e o questionário, por exemplo, para apreender outras formas de intenções e preferências. Mas reforça 
o acerto das escolhas feitas, em face desses dois instrumentos, a assunção de que atores políticos tenderiam a apresentar leituras enviesadas dos fatos passados, e que os textos obtidos da transcrição de entrevistas e questionários atenderiam a demandas diversas daquelas aqui empreendidas, tendo sido preferida a “entrevista” com as documentações produzidas no procedimento legislativo.

Embora não se incluam estudos de caso, admitida a ponderação de Lijphart (1971) acerca da concepção dessa ferramenta como parte implícita dos métodos comparativos, ter-se-á empreendido, de certo modo, o estudo de casos múltiplos, na medida em que se podem conceber as 27 narrativas mencionadas como estudos parciais de casos, a partir dos quais se extraíram as variáveis relacionadas ao processo decisório do veto, para cada legislatura, ano por ano.

Tendo por base a potencialidade do estudo de caso em produzir generalizações, Lijphart (1971) tipifica-o em ateórico, interpretativo, gerador de hipótese, confirmador de teoria, questionador de teoria, e desviante. O presente estudo apresenta vizinhança com o tipo gerador de hipótese, que se beneficia de um ponto de partida teórico preexistente e, a partir de hipóteses mais ou menos vagas, busca nos eventos a ocorrência proveitosa das variáveis de interesse.

Não se trata, porém, de uma aplicação do process tracing como definido por Bennet (2004), em que um único caso é investigado a fundo, com fito de estabelecer uma conexão entre os eventos observados e uma causa hipotética, tendo por base um escopo teórico de referência, a menos que se possa falar em process tracing múltiplo.

Cameron (2000) lança mão do event history, metodologia baseada na narrativa longitudinal, que emprega a metodologia de formalização matemática conhecida como método estocástico, com base em cadeias de $\operatorname{Markov}^{16}$, aplicada a processos dinâmicos como o processo decisório de veto. Com essa unidade de análise o autor explica o processo de barganha entre Presidente e Congresso norte-americanos na formação da lei quando não há consenso imediato, em contexto de governos divididos, ou seja, em que o partido do Presidente não garante maioria no Congresso.

\footnotetext{
${ }^{16}$ São formalizações matemáticas que consideram que a probabilidade condicional de qualquer evento futuro, dado qualquer evento passado e o estado presente é independente do evento passado e depende somente do estado presente.
} 
O presente estudo não se beneficia dos eventos do mesmo modo que o autor americano. A constatação inicial frente os dados obtidos já desestimula uma empresa tão ambiciosa quanto seria gerar um modelo. O Congresso brasileiro não decidiu sobre vetos de modo regular, tendo sido omisso sobre cerca de 20\% deles até o final do recorte observado, como se verá no Capítulo 4. A narrativa proposta não oferece uma análise dos eventos sobre o veto, voltada para sua predição, mas uma descrição da evolução dos procedimentos e regras ao longo do período, tendo em vista a predominância do não evento, da não decisão.

A tônica dessa narrativa é o exercício concreto do poder de agenda do Congresso, diante das restrições institucionais impostas pelo arcabouço constitucional e regimental, e em face dos desafios decisórios que caracterizam o período histórico vivido, marcado por um movimento de redemocratização e de experimentação das instituições postas em carga a partir de 1988.

O que se busca oferecer é uma análise histórico-descritiva longitudinal de 263 casos de sessões que objetivaram resolver 1.160 casos de vetos presidenciais, com base em documentos legislativos oficiais, de cujos conteúdos extraíram-se dados que, serem lidos, demandaram uma base teórica que considerasse o comportamento racional dos atores de decisões legislativas.

\subsection{Categorias conceituais}

Considera-se importante deixar estabelecidas aos leitores desta dissertação as escolhas de algumas categorias conceituais empreendidas. Busca-se, primeiramente, obedecer a um padrão na

terminologia, pois os conceitos não justificados poder-se-iam tornar pressupostos não comprovados. Como bem descreve Gerring (2012) os conceitos são “[...] os recipientes linguísticos que utilizamos para fragmentar o mundo empírico.” (p. 110)(tradução nossa). Objetiva-se tratar os conceitos de modo simples e direto, na estreita necessidade advinda dos dados obtidos e da base teórica utilizada.

Legislatura, coalizão e maioria:

Em razão da proximidade no campo conceitual, distinguem-se legislatura, coalizão e maioria. Norton (2013) define legislatura como "um corpo criado para aprovar medidas que 
formarão a lei da nação” (tradução nossa). Martin, Saalfeld e Strom (2014) mencionam então os termos parlamento, congresso e assembleia. Autores como Kreppel (2014) chegam a propor uma classificação das legislaturas, em que o termo assembleia formaria um conjunto mais amplo, incluindo a legislatura, esta subdividida em parlamentos e congressos, sendo os primeiros comuns ao parlamentarismo, e os segundos ao presidencialismo. No Parlamentarismo a legislatura (parlamento) estaria ligada organicamente ao chefe de governo, o que não ocorreria no Presidencialismo, uma vez que nele predominaria a separação estrita dos dois poderes, fazendo daí subentenderem-se o conflito e as regras eleitorais diversas para a seleção dos representantes dos dois ramos. São conceituações eminentemente funcionalistas.

Em termos constitucionais, a definição de legislatura é temporal: um período de quatro anos (BRASIL, 1988, art. 44). Além da concepção positiva, a legislatura pode ser vista também como corpo legislativo ou, de modo mais amplo, como “coletividades especializadas” (PALOMBARA, 1982), por via da representação. Uma vez que a cada período de quatro anos é possível renovar integralmente as cadeiras da Câmara dos Deputados e até dois terços das cadeiras do Senado Federal, tem-se que a formação das maiorias decisórias (incluídas ou não em uma coalizão governativa) sofre influência das transições advindas da formação da nova legislatura. Ao aspecto funcional soma-se o aspecto temporal.

Polsby (1975) vê a legislatura inicialmente como uma forma peculiar de organização, para então defini-la como uma organização de múltiplos propósitos, sendo o principal deles ligar os elementos do povo e do governo, por via da representação e com funções de legitimação e controle das forças revolucionárias. Fica claro que o autor se refere ao próprio ramo Legislativo do poder, analisando-o sob o ponto de vista de sua relevância para os sistemas políticos.

Forma-se, assim, a categoria conceitual e unidade analítica "legislatura”: o corpo coletivo decisório de formação da lei, cuja renovação é oportunizada a cada quatro anos, cuja posição na separação dos poderes é instaurada em bases de legitimação eleitoral distintas das do chefe de governo, com quem ela estabelece um potencial conflito no exercício da função de formação da lei. É pelo caráter essencial de vínculo entre Executivo e Legislativo que o conceito aplicado de legislatura avizinha-se ao de coalizão. 
Para Abranches (1988) coalizão é o agregado multipartidário que se reúne em torno de um projeto de poder em três momentos: o da eleição, o da formação do gabinete de governo (ministérios) e o da aprovação legislativa das políticas consensuais; seria, portanto, a maioria governativa formada por associações entre os poderes Executivo e Legislativo (ABRANCHES, 1988).

Analistas como Riker (1962) partem do conceito matemático de coalizão, que é o de jogo com “n” participantes, para determinar as leis de formação de coalizões na busca pela obtenção de maiorias a menores custos. Sendo assim, considera-se, embora o conceito não seja essencial à analise, que coalizão é o termo referente às alianças formais das Legislaturas com o núcleo político do Executivo, iniciadas com a campanha eleitoral, reafirmada na formação do Governo, por meio de Ministérios, e no número de cadeiras obtidas nas duas Casas do Congresso Nacional, com vistas a formação das leis conforme um dado programa de governo.

A maior parte da literatura pesquisada utiliza o termo coalizão, ou mesmo gabinete, em vez de legislatura. O conceito de coalizão não coincide sempre com o conceito de maioria, vide os casos de governos chamados minoritários, embora pareça ser o termo mais apropriado para as análises que se concentram na relação Executivo-Legislativo.

O termo maioria refere-se ao aglomerado decisório numericamente forte o bastante para preponderar em processos decisórios coletivos baseados no voto. Trata-se de um conceito transversal aos de coalizão e legislatura. Nem toda coalizão garante sempre a maioria na legislatura, em razão de questões relacionadas à disciplina partidária, entre outros fatores, de modo que um governo de grande coalizão eleitoral pode enfrentar grandes dificuldades para aprovar sua agenda. A maioria é a exigência da racionalidade nas decisões coletivas, tratando-se de um conceito funcional para os processos decisórios políticos. Uma coalizão pode e deve produzir maiorias, havendo coalizão sempre que houver a prevalência das preferencias de uma maioria que corresponda ao máximo aos seus membros.

Assim, por se tratar de estudo focado diretamente na atuação concreta do Poder Legislativo, em análise predominantemente longitudinal, apenas indiretamente calcada na relação Executivo-Legislativo, a categoria legislatura apresenta-se como a mais apropriada para a agregação dos dados. A legislatura é o local onde se veem formar coalizões, capazes ou não de 
produzir maiorias, os móveis de decisão. A categoria legislatura abrange a de coalizão e de maioria, considerado o elemento temporal, marca da análise longitudinal como a que se propõe a presente dissertação.

Citam-se como elementos da legislatura importantes para o processo decisório do veto: o plenário conjunto, o Presidente do Senado como presidente do Congresso, as lideranças partidárias e o Presidente da República. Cada um desses elementos figura, em um ou outro momento, no fluxo da produção legal, pela ótica da apreciação do veto (ver os fluxos das Figuras 2 e 3 do Capítulo 1) e, como tal, compõe a estrutura organizacional que embasa o processo decisório em estudo.

Estoque de veto: a prática de apreciação intempestiva e anômala do Congresso Nacional é regra desde a primeira hora da vida constitucional pós 1988. A dificuldade em lidar com os vetos apostos na própria legislatura somou-se à dificuldade em lidar com um passivo deliberativo representado por vetos que deixavam de ser votados por legislaturas antecedentes. Chama-se de estoque esse montante. $\mathrm{O}$ estoque influencia o rendimento deliberativo tanto no montante a ser deliberado por cada legislatura quanto no montante resolvido por cada uma. Trata-se de uma das variáveis explicativas centrais ao desenvolvimento da argumentação.

Tempo: ao lado do estoque, essa variável figura como elemento central da mensuração do fenômeno da não decisão sobre os vetos. Ao mesmo tempo trata-se de uma das principais explicações teóricas para o não decidir defensivo do congresso, ou seja, sua opção por defender uma agenda limitada no espaço e no tempo, evitando os conflitos advindos da arena do veto.

Resolução de vetos: o termo é empregado para incluir tanto o percentual anual das decisões obtidas por meio de votação propriamente dita, quanto o obtido com as declarações de prejudicialidade, resultados mais frequentes que as rejeições de vetos, mas que não podem ser consideradas deliberações propriamente ditas.

Resolução simples: trata-se da capacidade percentual anual de cada legislatura de decidir sobre os vetos praticados pelo Presidente da República no lapso temporal daquela mesma legislatura. Trata-se da divisão do número de vetos pertencentes à legislatura e resolvidos nela, pelo número de vetos surgidos durante a própria legislatura. 
Resolução com estoques: termo que explica a decisão percentual anual dos vetos resolvidos, independentemente da legislatura, tendo em vista estoques herdados. É obtido pela divisão da soma de vetos resolvidos pertencentes à legislatura e herdados de legislaturas anteriores pela soma de vetos surgidos na legislatura a estoques herdados. A grandeza permite mensurar a preferência do Legislativo em lidar com estoques mais antigos.

Resolução sem estoques: o termo não se refere ao resultado de um cálculo apenas matemático. É obtido pelo mesmo cálculo que a Resolução com Estoques, mas removendo-se da parcela de vetos recebidos o estoque herdado, ou seja, considerando-se somente o estoque pertencente à legislatura. Defende-se a inclusão dessa grandeza para efeitos de ilustração do fato de que um rendimento alto não traduziria necessariamente proatividade legislativa na arena de vetos, como se verá.

Não decisão: além da explicação teórica, o termo aplica-se a uma grandeza mensurada na Análise dos dados, empregando-se a mesma adjetivação aplicada às resoluções (simples, com estoques e sem estoques). Em outras palavras, trata-se da face oposta da resolução, com o objetivo de oferecer uma mensuração do fenômeno de não decisão.

Obsolescência: aplica-se o termo como forma de expressar sua característica de ferramenta de excesso praticada pelo Presidente da República na consecução de sua agenda substantiva, com preponderância de iniciativas e forte comando sobre o ritmo de tramitação. Admitidas as concepções de que o veto somente é visto em sua inteireza se considerada sua fase legislativa, e de que uma separação de poderes sem distinção de agendas prescinde do veto, aportam-se dados empíricos para corroborar a utilidade dessa categoria conceitual para abordar as consequências prováveis do comportamento do Legislativo sobre o instituto do veto na experiência histórica concreta. 


\section{4 - ANÁLISE DOS RESULTADOS}

Cumpridos os objetivos de explicitar o processo decisório do veto expresso por normas e regras e de relacionar poder de agenda do Legislativo e seus efeitos sobre o instituto do veto, passa-se à análise tanto das regras e procedimentos quanto da não decisão. Procura-se oferecer uma síntese dos pressupostos até aqui argumentados, bem como apresentar dados empíricos resultantes da pesquisa e que corroboram esses argumentos.

\subsection{Explicando as alterações institucionais do processo decisório de veto.}

Entre as regras constitucionais mais relevantes para essa evolução de regras e procedimentos regimentais, destacam-se duas. A primeira é a mudança da concepção de veto, de negativa de sanção à ação positiva de negar, que resulta na autuação da mensagem presidencial como matéria legislativa autônoma no Congresso. Nos regimes constitucionais anteriores, o projeto é que retornava, acompanhado das razões da negativa, a fim de que se o pudesse reconsiderar, agora retornam as razões presidenciais de veto, acompanhadas dos autógrafos originais. Essa sutileza teve, como se viu, consequências sobre a evolução do modo como o Congresso decide sobre os vetos.

A segunda mudança de paradigma constitucional diz respeito ao quórum, e pode levar a confusões analíticas. Grohmann (2003), por exemplo, dedica boa parte de sua tese a explicar a formação de coalizões, sob o ponto de vista de suas dimensões e disciplinas, relacionando-os ao quórum de "derrubada” do veto. O escopo analítico empregado pelo autor foi o mesmo para os dois períodos: 1946-1964 e 1990-2000. Ocorre que o veto pós 1988 é deliberado mediante quórum negativo, ao contrário do que ocorria no período democrático anterior, em que se tratava de um quórum positivo, que reafirmava o projeto. Em outras palavras, o veto não é votado para que seja aprovado, mas para que seja rejeitado.

O veto retorna para teste de um quórum de rejeição. Não existe previsão de quórum para manutenção do veto, o que significa que, atingido o quórum mínimo deliberativo, previsto pelo 
art. 47 da Constituição Federal - regra constitucional geral de maioria (BRASIL, 1988), somente nova maioria, dessa vez a maioria de negativas ao veto, resulta em mudanças no status quo. Não é necessário, portanto, uma maioria absoluta para manter vetos. Uma maioria simples o fará.

Disso resulta que, para analisar o veto sob o ponto de vista da relação entre os poderes, há que se pressupor que a maioria não é desejada pelo Presidente da República. Ao contrário, interessa-lhe a falta de quórum, porque a maioria pode superá-lo. Daí porque, ao se analisar a apreciação de vetos pelo Congresso Nacional pelo ângulo de variáveis como quórum e disciplina partidária, não faz muito sentido observar somente a aprovação dos projetos.

Pelo que se viu até aqui, as regras e procedimentos constituem importantes bases institucionais dos processos decisórios. A dinâmica de sua formação, emprego, transformação e ocaso é intrincada e de difícil descrição. Muller e Sieberer (2014) elencam características para o que consideram ser "boas regras": devem ser reconhecidas como legítimas tanto por parte daqueles que agem sob as regras quanto por aqueles que estariam sujeitos às consequências de sua aplicação; devem ser simples e não ambíguas; devem ser aplicáveis a todas as situações idênticas; e devem comportar todas as questões relevantes.

O conjunto de regras e procedimentos adotados pelo Congresso ao longo de 27 anos de vida constitucional formataram um modus operandi baseado na deliberação livre sobre o veto, sendo que a constrição institucional promovida pela regra do trancamento de pauta não foi obstáculo para a agenda do Legislativo. Evidência elementar é o fato de haver um veto aposto em 2000 ainda em tramitação (Veto ${ }^{\circ} 44$ de 2000), o que atesta estar a pauta trancada desde então, sem paralisia nas demais deliberações.

Quanto à natureza dessas alterações, o Quadro 5, abaixo, resume as transformações nas regras e procedimentos relacionados ao processo decisório de veto. 
Quadro 5: Alterações Institucionais do processo decisório de vetos

\begin{tabular}{|c|l|l|}
\hline Legislatura & \multicolumn{1}{|c|}{ Regimentais/Constitucionais } & \multicolumn{1}{|c|}{ Procedimentais } \\
\hline $48^{\mathrm{a}}$ & & Painel eletrônico \\
\hline $48^{\mathrm{a}}$ & & Votação de veto parcial em partes \\
\hline $48^{\mathrm{a}}$ & & $\begin{array}{l}\text { Prejudicialidade de veto incluído em } \\
\text { pauta }\end{array}$ \\
\hline $48^{\mathrm{a}}$ & & Votação global de veto parcial \\
\hline $49^{\mathrm{a}}$ & & Cédula única de votações \\
\hline $50^{\mathrm{a}}$ & & Prejudicialidade de veto não pautado \\
\hline $51^{\mathrm{a}}$ & Emenda Constitucional n. 32/2001 & $\begin{array}{l}\text { Discussão conjunta e concomitante com a } \\
\text { votação }\end{array}$ \\
\hline $52^{\mathrm{a}}$ & & Atraso da leitura do veto \\
\hline $53^{\mathrm{a}}$ & & Regime de urgência regimental \\
\hline $54^{\mathrm{a}}$ & Resolução do Congresso Nacional $\mathrm{n}^{\mathrm{o}} 1 / 2013$ & \\
\hline $54^{\mathrm{a}}$ & Emenda Constitucional n. $76 / 2013$ & \\
\hline
\end{tabular}

Fonte: Elaboração própria

Nota-se que somente na $51^{\mathrm{a}}$ Legislatura surge a primeira alteração jurídica de regra, produzida por processo legislativo regular, ainda que atingindo de modo indireto o processo decisório do veto. Somente na 54 $4^{\mathrm{a}}$ Legislatura, depois de 26 anos de vigência da Constituição, surgem alterações jurídicas diretamente relacionadas ao veto. Já as alterações de ordem procedimental, para as quais concorrem somente o consenso e o contexto, dispensando o processo regular de formação de normas jurídicas, surgem mais cedo e são mais frequentes.

Como exposto, as primeiras se mostraram mais efetivas que as segundas. Mesmo com a criação do importante mecanismo da cédula de votações, o padrão de deliberação somente se modificou com a regra da Resolução $n^{0} 1$ de 2013, quando as sessões de vetos voltaram a ser frequentes, apesar do já mencionado fenômeno de congelamento do estoque.

Quando necessário, o veto foi tomado como matéria ordinária, à qual se aplicaram regras gerais de processo legislativo, como o requerimento de urgência e a declaração de prejudicialidade. As raras rejeições se deram por ambos os métodos disponíveis de votação, com prevalência do painel eletrônico, em razão da maior visibilidade da votação por esse método, mas o ânimo de rejeitar não modificou profundamente o modo de regrar a deliberação. 
O histórico procedimental atesta que o Congresso não tratou do processo decisório de veto em um "estado de natureza legislativo”. As dificuldades em lidar com agenda forçada de vetos cada vez mais numerosos colocaram o legislador diante de escolhas complexas. A evolução do estoque transferido já da primeira legislatura pós 1988 para segunda, gerou um sistema de déficit deliberativo desafiador. As soluções foram encontradas, e foram sendo adotadas pelas legislaturas que se sucederam, visando cumprir a tarefa de deliberação sobre os vetos.

Além disso, ainda que não tenha sido mensurada, percebe-se a influência dos fenômenos externos eleitoras e político-econômicos sobre a agenda do Legislativo. Como se viu, a agenda é temporalmente restrita, e os atores políticos têm de se mover em um espaço restringido pelas normas. Os jogos ocultos (TSEBELIS, 1998) atestam a realidade e múltiplas arenas do jogo político. O Quadro 6 abaixo lista as principais ocorrências.

Quadro 6: Agenda eleitoral e políticoeconômica

\begin{tabular}{|c|c|c|c|}
\hline Legislatura & Ano & Calendário Eleitoral & Fatos Políticos e Econômicos \\
\hline \multirow{3}{*}{$48^{\mathrm{a}}$} & 1988 & Municipais & $\begin{array}{l}\text { - Promulgada a nova Constituição do Brasil } \\
\text { (em vigor até hoje) } \\
\text { - Em 1987, ocorrera a queda histórica do Dow } \\
\text { Jones (2 }{ }^{\text {a }} \text { feira negra) }\end{array}$ \\
\hline & 1989 & Executivo Federal & Plano Verão (cruzado novo) \\
\hline & 1990 & $\begin{array}{l}\text { Executivos } \quad \text { e } \\
\text { Estaduais e Legislativo Federal }\end{array}$ & $\begin{array}{l}\text { Collor lança o Plano Collor I (cruzeiro), plano } \\
\text { econômico revolucionário, cria uma nova } \\
\text { moeda e congela depósitos bancários por } \\
\text { dezoito meses }\end{array}$ \\
\hline \multirow{4}{*}{$49^{\mathrm{a}}$} & 1991 & & Plano Collor II \\
\hline & 1992 & Municipais & $\begin{array}{l}\text { - Collor renuncia à presidência da República, } \\
\text { após acusações de corrupção e investigação da } \\
\text { CPI } \\
\text { - Aprovação de } 2 \text { Emendas Constitucionais }\end{array}$ \\
\hline & 1993 & & $\begin{array}{l}\text { - Plebiscito popular opta pelo presidencialismo } \\
\text { republicano como sistema de governo. Nova } \\
\text { reforma cria o cruzeiro real } \\
\text { - Aprovação de } 2 \text { Emendas Constitucionais }\end{array}$ \\
\hline & 1994 & $\begin{array}{l}\text { Gerais: Executivos e Legislativos } \\
\text { Federal e Estaduais }\end{array}$ & $\begin{array}{l}\text { Plano Real. O ministro da Fazenda, Fernando } \\
\text { Henrique Cardoso, candidata-se à Presidência } \\
\text { da República e vence }\end{array}$ \\
\hline \multirow[t]{2}{*}{$50^{\mathrm{a}}$} & 1995 & & $\begin{array}{l}\text { - Inicia-se processo de privatizações. } \\
\text { - Aprovação de } 5 \text { Emendas Constitucionais: } \\
\text { Privatização das telecomunicações, concessão } \\
\text { de petróleo; entre outras }\end{array}$ \\
\hline & 1996 & Municipais & $\begin{array}{l}\text { - Aprovação de } 6 \text { Emendas Constitucionais: } \\
\text { criação da contribuição provisória sobre } \\
\text { movimentação ou transmissão de valores - }\end{array}$ \\
\hline
\end{tabular}




\begin{tabular}{|c|c|c|c|}
\hline Legislatura & Ano & Calendário Eleitoral & Fatos Políticos e Econômicos \\
\hline & & & $\begin{array}{l}\text { CPMF; quebra do monopólio do Instituto } \\
\text { Brasileiro de Resseguros - IRB; criação do } \\
\text { Fundo de Manutenção e Desenvolvimento do } \\
\text { Ensino Fundamental e de Valorização do } \\
\text { Magistério (FUNDEF); entre outras. }\end{array}$ \\
\hline & 1997 & & $\begin{array}{l}\text { - A sociedade clama por reformas sociais, } \\
\text { entre elas a Tributária, da Previdência e da } \\
\text { Saúde. Governo de Fernando Henrique } \\
\text { preocupa-se com a aprovação da emenda para } \\
\text { reeleições } \\
\text { - Crise dos Tigres Asiáticos } \\
\text { - Aprovação de } 2 \text { Emendas Constitucionais: } \\
\text { reeleição e redução de mandatos; Fundo Social } \\
\text { de Emergência e repasse de Imposto de Renda } \\
\text { a Municípios. }\end{array}$ \\
\hline & 1998 & $\begin{array}{l}\text { Gerais: Executivos e Legislativos } \\
\text { Federal e Estaduais }\end{array}$ & $\begin{array}{l}\text { - Crise da Rússia } \\
\text { - Aprovação de } 3 \text { Emendas Constitucionais: } \\
\text { Primeiras reformas administrativa e da } \\
\text { previdência. }\end{array}$ \\
\hline \multirow{4}{*}{$51^{\mathrm{a}}$} & 1999 & & $\begin{array}{l}\text { - Aprovação de } 4 \text { Emendas Constitucionais: } \\
\text { primeira renovação da CPMF; entre outras. }\end{array}$ \\
\hline & 2000 & Municipais & $\begin{array}{l}\text { - Aprovação de } 7 \text { Emendas Constitucionais: } \\
\text { redução de gastos com } \text { vereadores; } \\
\text { desvinculação de receitas da União (DRU); } \\
\text { criação dos mínimos com saúde; primeira } \\
\text { reforma dos precatórios; criação do fundo de } \\
\text { combate e erradicação da pobreza; entre } \\
\text { outras. }\end{array}$ \\
\hline & 2001 & & $\begin{array}{l}\text { - Ataques de } 11 \text { de setembro } \\
\text { - Aprovação de } 4 \text { Emendas Constitucionais }\end{array}$ \\
\hline & 2002 & $\begin{array}{l}\text { Gerais: Executivos e Legislativos } \\
\text { Federal e Estaduais }\end{array}$ & - Aprovação de 4 Emendas Constitucionais \\
\hline \multirow{4}{*}{$52^{\mathrm{a}}$} & 2003 & & $\begin{array}{l}\text { - Aprovação de } 3 \text { Emendas Constitucionais: } \\
\text { segunda reforma da previdência; outra } \\
\text { renovação da CPMF; flexibilização do sistema } \\
\text { financeiro nacional. }\end{array}$ \\
\hline & 2004 & Municipais & - Aprovação de 3 Emendas Constitucionais: \\
\hline & 2005 & & - Aprovação de 3 Emendas Constitucionais \\
\hline & 2006 & $\begin{array}{l}\text { Gerais: Executivos e Legislativos } \\
\text { Federal e Estaduais }\end{array}$ & $\begin{array}{l}\text { - Aprovação de } 5 \text { Emendas Constitucionais: } \\
\text { fim da verticalização das candidaturas } \\
\text { (partidos e esferas da federação); entre outras. }\end{array}$ \\
\hline \multirow{2}{*}{$53^{\mathrm{a}}$} & 2007 & & - Aprovação de 3 Emendas Constitucionais \\
\hline & 2008 & Municipais & - Crise da Bolha Imobiliária \\
\hline
\end{tabular}




\begin{tabular}{|c|c|c|c|}
\hline Legislatura & Ano & Calendário Eleitoral & Fatos Políticos e Econômicos \\
\hline & & & - Aprovação de 1 Emenda Constitucional \\
\hline & 2009 & & $\begin{array}{l}\text { - Aprovação de } 5 \text { Emendas Constitucionais: } \\
\text { segunda reforma dos precatórios; entre outras. }\end{array}$ \\
\hline & 2010 & $\begin{array}{l}\text { Gerais: Executivos e Legislativos } \\
\text { Federal e Estaduais }\end{array}$ & $\begin{array}{l}\text { - Aprovação de } 5 \text { Emendas Constitucionais: } \\
\text { prorrogação, por prazo indeterminado, do } \\
\text { fundo de erradicação da pobreza; entre outras. }\end{array}$ \\
\hline \multirow{4}{*}{$54^{\mathrm{a}}$} & 2011 & & $\begin{array}{l}\text { - Aprovação de } 1 \text { Emenda Constitucional: } \\
\text { prorrogação da DRU. }\end{array}$ \\
\hline & 2012 & Municipais & - Aprovação de 3 Emendas Constitucionais \\
\hline & 2013 & & $\begin{array}{l}\text { - Manifestações Populares de junho } \\
\text { - Aprovação de } 5 \text { Emendas Constitucionais: } \\
\text { fim do voto secreto para cassações e vetos; } \\
\text { entre outras. }\end{array}$ \\
\hline & 2014 & $\begin{array}{l}\text { Gerais: Executivos e Legislativos } \\
\text { Federal e Estaduais }\end{array}$ & - Aprovação de 8 Emendas Constitucionais \\
\hline
\end{tabular}

Fontes: Sistemas de Informação do Senado Federal e da Câmara dos Deputados, Diário do Senado Federal e do Congresso Nacional; Relatório Anual da Presidência do Senado Federal, e Nicolau (2012).

Nota: mencionadas apenas emendas consideradas como de maior impacto.

Como já exposto, a $48^{\mathrm{a}}$ Legislatura viveu três grandes processos eleitorais, uma assembleia constituinte e dois planos econômicos de grande vulto. A partir de então, todas as legislaturas foram submetidas a uma rotina eleitoral de anos pares, eleições municipais e gerais. Como ilustrado pelos gráficos da Figura 5, o ritmo eleitoral parece ter influenciado fortemente o ritmo das sessões conjuntas.

Destacam-se as intensas modificações constitucionais da 50a Legislatura (FHC I), tendo sido aprovadas 19 emendas constitucionais, fortalecendo a argumentação da agenda intensa com consequente redução de sessões conjuntas, como analisado em 5.3. O ritmo médio foi de 14 emendas constitucionais por legislatura (quase 4 por ano), com os já conhecidos custos de aprovação, dado que se trata de processo legislativo com quórum de aprovação elevado (3/5 dos membros das casas em dois turnos). No ambiente externo, foram várias crises econômicas mundiais, afetando principalmente o mercado financeiro, com efeitos sobre as políticas no ambiente doméstico.

Merece destaque também a predominância do Partido do Movimento Democrático Brasileiro - PMDB na presidência do Senado Federal, e consequentemente do Congresso Nacional, ilustrado no Quadro 7 abaixo: 
Quadro 7: Partidos nas Presidências do Congresso e da República

\begin{tabular}{|c|l|l|}
\hline Legislatura & Presidências do Congresso Nacional & Presidência da República \\
\hline $48^{\mathrm{a}}$ & PMDB/PMDB & PMDB \\
\hline $49^{\mathrm{a}}$ & PMDB/PMDB & PRN/PMDB \\
\hline $50^{\mathrm{a}}$ & PMDB/PFL & PSDB \\
\hline $51^{\mathrm{a}}$ & PFL/PMDB & PSDB \\
\hline $52^{\mathrm{a}}$ & PMDB/PMDB & PT \\
\hline $53^{\mathrm{a}}$ & PMDB/PMDB & PT \\
\hline $54^{\mathrm{a}}$ & PMDB/PMDB & PT \\
\hline
\end{tabular}

Fonte dos dados brutos: Sistemas de Informação do Senado Federal e da Câmara dos Deputados, Diário do Senado Federal e do Congresso Nacional; Relatório Anual da Presidência do Senado Federal.

Nota: o Presidente do Senado Federal é também Presidente do Congresso Nacional.

Das 14 presidências do Congresso Nacional, 12 foram ocupadas pelo PMDB, partido mais frequentemente localizado no centro da base de coalizão de todos os Presidentes da República do período estudado. Isso corrobora as análises existentes que consideram a relevância do partido na formação do presidencialismo de coalizão brasileiro, e o posiciona como o partido do Legislativo, visto que sua frequência no Executivo restringe-se ao mandato não eleito de José Sarney. O agregado decisório Executivo-Legislativo para o veto, formado a partir de 1988, tem como elemento certo o partido em questão.

Por fim, para analisar a apreciação de vetos, recomenda-se começar pela constatação de que o Congresso delibera de modo excêntrico e raramente os rejeita. A contribuição do assunto para a ciência política parece encontrar-se nessa característica inegável de inércia relativa. Notase que, independentemente do conteúdo das criações e adaptações normativas, facilitadoras ou complicadoras, a efetiva deliberação congressual sobre vetos decresceu paulatinamente. Configurou-se o fenômeno da não decisão, representado pela apreciação tardia, anômala ou ausente dos vetos, tema da Seção 1.3 e da próxima seção, que analisa os dados sobre o fenômeno. 


\subsection{Explicando o Não decidir (1988-2014)}

Evidenciam-se, a seguir, os efeitos da lógica dos estoques para melhorar a compreensão do exercício concreto do poder de agenda do Congresso.

Ao final do recorte temporal amostrado, verifica-se a existência de 229 vetos presidenciais pendentes de deliberação; menos de 3\% dos 956 vetos resolvidos, o foram no prazo constitucional $^{17}$, e menos de $30 \%$ foram resolvidos pela mesma legislatura que sofreu os vetos. Trata-se de quase 20\% de não decisão. O estoque está congelado, conforme se viu, por força da Resolução do Congresso Nacional $n^{\circ}$ 1, de 2013, e o valor não decrescerá enquanto não se incluam tais vetos em ordem do dia do Congresso, o que não mais ocorreu depois da promulgação da referida norma. Essa solução marca o surgimento de duas categorias de vetos, sobre os quais incidiriam agendas e regras diversas.

Tabela 2: Apreciação do veto - 1988-2014

\begin{tabular}{l|r|r}
\hline RESULTADO & ABSOLUTO & \multicolumn{2}{|c}{$\%$} \\
\hline Mantido & 862 & $73 \%$ \\
\hline Rejeitado & 27 & $2 \%$ \\
\hline Prejudicado & 67 & $6 \%$ \\
\hline Tramitando & 229 & $19 \%$ \\
\hline Totais & 1185 & $100 \%$ \\
\hline
\end{tabular}

Fonte: Sistemas de Informação do Senado Federal e da Câmara dos Deputados, Diário do Senado Federal e do Congresso Nacional, Relatório Anual da Presidência do Senado Federal.

É preciso, no entanto, compreender a evolução do rendimento deliberativo que levou a esse estoque congelado, o grau de não decisão, que ao fim resultou nesse considerável déficit deliberativo. A resolução dos vetos deu-se, ao longo das legislaturas que se sucederam, com a marca da formação de um estoque. A não decisão foi mensurada por meio do percentual de resolução dos vetos a cada legislatura, distinguindo a resolução dos vetos apostos dentro da legislatura e aqueles provenientes de estoques herdados de legislaturas anteriores. Quanto maior o

\footnotetext{
${ }^{17}$ Ver a respeito a Tabela 12, no Apêndice, em que se listam os vetos por tempo de tramitação.
} 
estoque herdado, maior a pauta de vetos antigos, retirando espaço em pauta para os vetos mais novos.

Isso não ocorreu tão somente por não se apreciarem vetos, mas por haver a necessidade de se resolverem vetos sobre cujos temas sequer havia calor político para uma deliberação propriamente dita. Assim, chama-se não “decisão simples” o déficit deliberativo das legislaturas, considerados apenas os vetos nela apostos (Tabela 3).

Tabela 3: Sessões: 1988-2014 - Não Decisão Simples

\begin{tabular}{|c|c|c|c|}
\hline & $\begin{array}{c}\text { Vetos da } \\
\text { Legislatura } \\
\end{array}$ & $\begin{array}{c}\text { Resolvidos da } \\
\text { Legislatura } \\
\end{array}$ & $\begin{array}{l}\text { Não Decisão } \\
\text { Simples (\%) }\end{array}$ \\
\hline $48^{a}$ & 125 & 77 & 33,2 \\
\hline $49^{a}$ & 220 & 81 & 65,2 \\
\hline $50^{a}$ & 152 & 22 & 90,5 \\
\hline $51^{a}$ & 150 & 17 & 83,4 \\
\hline $52^{a}$ & 153 & 6 & 95,9 \\
\hline $53^{\mathrm{a}}$ & 207 & 1 & 99,4 \\
\hline $54^{\mathrm{a}}$ & 178 & 57 & 63,9 \\
\hline
\end{tabular}

Fonte: Sistemas de Informação do Senado Federal e da Câmara dos Deputados, Diário do Senado Federal e do Congresso Nacional, Relatório Anual da Presidência do Senado Federal.

A não decisão quase integral dos vetos praticados no lapso da própria legislatura, ou não decisão simples, foi regra para quatro das sete legislaturas pós-constitucionais estudadas. Somente a $51^{\mathrm{a}}$ (FHC) e a $54^{\mathrm{a}}$ (Dilma) Legislaturas revertem a tendência de deixar de lado os vetos novos. A 49a Legislatura, que teve dois Presidentes da República, foi a que mais vetos experimentou e mais vetos resolveu, em valores absolutos. A proporção da $54^{a}$ é parecida. Notase a nítida tendência a um maior percentual de não decisão simples nas $51^{\mathrm{a}}$ a $53^{\mathrm{a}}$ Legislaturas, chegando-se a quase $100 \%$.

Compreender essa forma simples de não decisão seria suficiente para compreender o fenômeno. Mas, os dados podem ser vistos de outra forma, ao se considerarem os estoques transferidos/herdados. A “não decisão com estoques” é, portanto, a que considera o déficit deliberativo a partir da soma dos vetos da legislatura aos vetos do estoque (Tabela 4). 
Tabela 4: Sessões: 1988-2014 - Não Decisão com Apreciação de Estoques Herdados (médias anuais)

\begin{tabular}{c|c|c|c}
\hline & $\begin{array}{c}\text { Vetos da } \\
\text { Legislatura }+ \\
\text { Estoques (a) }\end{array}$ & $\begin{array}{c}\text { Resolvidos da } \\
\text { Legislatura (b) }\end{array}$ & $\begin{array}{c}\text { Não Decisão } \\
\text { com Estoques } \\
(\% \mathbf{b} / \mathbf{a})\end{array}$ \\
\hline $48^{\mathrm{a}}$ & 125 & 77 & 31,9 \\
\hline $49^{\mathrm{a}}$ & 264 & 81 & 45,7 \\
\hline $50^{\mathrm{a}}$ & 201 & 22 & 82,7 \\
\hline $51^{\mathrm{a}}$ & 275 & 17 & 71,1 \\
\hline $52^{\mathrm{a}}$ & 286 & 6 & 80,5 \\
\hline $53^{\mathrm{a}}$ & 338 & 1 & 76,7 \\
\hline $54^{\mathrm{a}}$ & 308 & 57 & 92,8 \\
\hline
\end{tabular}

Fonte: Sistemas de Informação do Senado Federal e da Câmara dos Deputados, Diário do Senado Federal e do Congresso Nacional, Relatório Anual da Presidência do Senado Federal.

A “não decisão com estoques” revela distinções inexistentes na Tabela 3. Por exemplo, considerados os estoques, a $54^{\mathrm{a}}$ Legislatura apresenta o maior percentual de não decisão. A $53^{\mathrm{a}}$ Legislatura tratou de um estoque total maior e apresenta uma não decisão percentual, embora alta, bem menor que a $54^{\mathrm{a}}$. A $49^{\mathrm{a}}$ Legislatura apresenta uma baixa não decisão com estoques, fato justificável talvez pelo tempo de Constituição em vigor.

Uma terceira forma de se observar a não decisão mensura o percentual de déficit deliberativo considerado, no entanto, a resolução de vetos herdados de outras legislaturas. Isso porque se nota que em alguns anos e legislaturas, o número de vetos resolvidos suplantou o de vetos apostos no respectivo período. Trata-se da "não decisão sem estoques" (Tabela 5). Sem estoques quer dizer que a não decisão foi mensurada sem se somar o estoque recebido, somandose, no entanto, os vetos resolvidos do estoque herdado. 
Tabela 5: Sessões: 1988-2014 - Não Decisão sem Contabilização de Estoques Herdados (médias anuais)

\begin{tabular}{c|c|c|c|c}
\hline & $\begin{array}{c}\text { Vetos da } \\
\text { Legislatura } \\
\text { sem Estoques }\end{array}$ & $\begin{array}{c}\text { Resolvidos da } \\
\text { Legislatura }\end{array}$ & $\begin{array}{c}\text { Resolvidos do } \\
\text { Estoque } \\
\text { Herdado }\end{array}$ & $\begin{array}{c}\text { Não Decisão } \\
\text { Sem Estoques } \\
(\%)\end{array}$ \\
\hline $48^{\text {a }}$ & 125 & 77 & 4 & 30,9 \\
\hline $49^{\text {a }}$ & 220 & 81 & 134 & 3,3 \\
\hline $50^{\text {a }}$ & 152 & 22 & 54 & 64,0 \\
\hline $51^{\text {a }}$ & 150 & 17 & 125 & $-98,2$ \\
\hline $52^{\text {a }}$ & 153 & 6 & 149 & $-10,0$ \\
\hline $53^{\text {a }}$ & 207 & 1 & 207 & 17,2 \\
\hline $54^{\text {a }}$ & 178 & 57 & 22 & 50,3 \\
\hline
\end{tabular}

Fonte: Sistemas de Informação do Senado Federal e da Câmara dos Deputados, Diário do Senado Federal e do Congresso Nacional, Relatório Anual da Presidência do Senado Federal.

Essa mensuração traz as oscilações mais intensas. Os números chegam a perder o sentido em situações como nas $51^{\mathrm{a}}$ e $52^{\mathrm{a}}$ Legislaturas, em que o percentual negativo remete a uma não decisão negativa, ou uma paradoxal “sobredecisão”. Convém, nesse caso, inverter a categoria conceitual e mensurar a capacidade de resolução dessas duas legislaturas ano a ano, para mais bem observar o fenômeno.

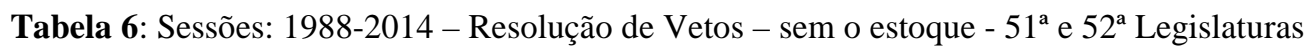
(médias anuais)

\begin{tabular}{r|r|r|r|r}
\hline Ano & $\begin{array}{c}\text { Vetos } \\
\text { Apostos }\end{array}$ & $\begin{array}{c}\text { Vetos } \\
\text { Resolvidos }\end{array}$ & $\begin{array}{c}\text { \% } \\
\text { Resolução }\end{array}$ & $\begin{array}{c}\mathbf{N}^{\mathbf{0}} \text { de } \\
\text { Sessões } \\
\text { conjuntas }\end{array}$ \\
\hline 1999 & 16 & 118 & $737,5 \%$ & 4 \\
\hline 2000 & 44 & 18 & $40,9 \%$ & 1 \\
\hline 2001 & 52 & 2 & $3,8 \%$ & 0 \\
\hline 2002 & 38 & 4 & $10,5 \%$ & 0 \\
\hline 2003 & 46 & 2 & $4,3 \%$ & 0 \\
\hline 2004 & 35 & 142 & $405,7 \%$ & 1 \\
\hline 2005 & 37 & 9 & $24,3 \%$ & 2 \\
\hline 2006 & 35 & 2 & $5,7 \%$ & 0 \\
\hline
\end{tabular}

Fonte: Sistemas de Informação do Senado Federal e da Câmara dos Deputados, Diário do Senado Federal e do Congresso Nacional, Relatório Anual da Presidência do Senado Federal. 
A Tabela 6 revela que os anos de 1999 (primeiro da 51ª Legislatura) e 2004 (segundo da $52^{\mathrm{a}}$ Legislatura) registram um rendimento deliberativo desproporcional, expresso por raras sessões conjuntas (apenas uma em 2004), nas quais se atacaram predominantemente os estoques herdados. Esse alto rendimento, quando considerado apenas o montante de vetos pertencentes à própria legislatura (sem estoques, portanto), ilustra a preferência por “estoques” frios, já antigos, o que demonstra que nem sempre um percentual alto de resolução (percentual baixo de "não decisão”, dito de modo contrário), afasta o caráter de evitamento do conflito, marca do não decidir.

Além desse aspecto, ressalte-se que esse rendimento alto atípico trouxe reflexos negativos sobre a "não decisão simples”, a omissão em deliberar sobre os próprios vetos, pois não houve espaço na agenda para eles. Todos os 260 vetos apreciados naqueles dois anos foram mantidos. Em outras palavras, o custo de se ter deliberado sobre os vetos transferidos foi a elevação de não decisão nos vetos da própria legislatura, o estoque “quente”.

Esse rendimento elevado foi obtido graças ao emprego da cédula única de votações, já detalhada. Essa conclusão qualifica a não decisão, na medida em que indica que a utilização da cédula ocorreu juntamente com a redução do número de sessões realizadas, permitindo, ao mesmo tempo, rendimentos desproporcionais, embora o estoque transferido tenha permanecido alto. Em outras palavras, a não decisão negativa da Tabela 5 para as $51^{\mathrm{a}}$ e $52^{\mathrm{a}}$ Legislaturas não quer dizer que elas foram mais efetivas, mas sim que mesmo sua efetividade é tradução de regras voltadas para a decisão cada vez mais episódica, sobre os vetos sobre os quais provavelmente não havia mais conflito.

A análise atesta a relevância do estoque transferido, a começar do primeiro estoque transferido de 44 vetos, da primeira para a segunda legislatura pós Constituição de 1988. Em face dessa lógica de estoques, a capacidade de "resolução simples”, que leva em conta tão somente as obrigações da respectiva legislatura, foi alterada, tanto para menos quanto para mais, como restou evidenciado pela "não decisão simples”.

O Gráfico da Figura 13 a seguir sumariza a evolução dessas três formas de se mensurar a não decisão do Congresso sobre vetos: simples, com estoques e sem estoques. 
Figura 13: Gráfico de não decisão por legislatura, conforme estoques.

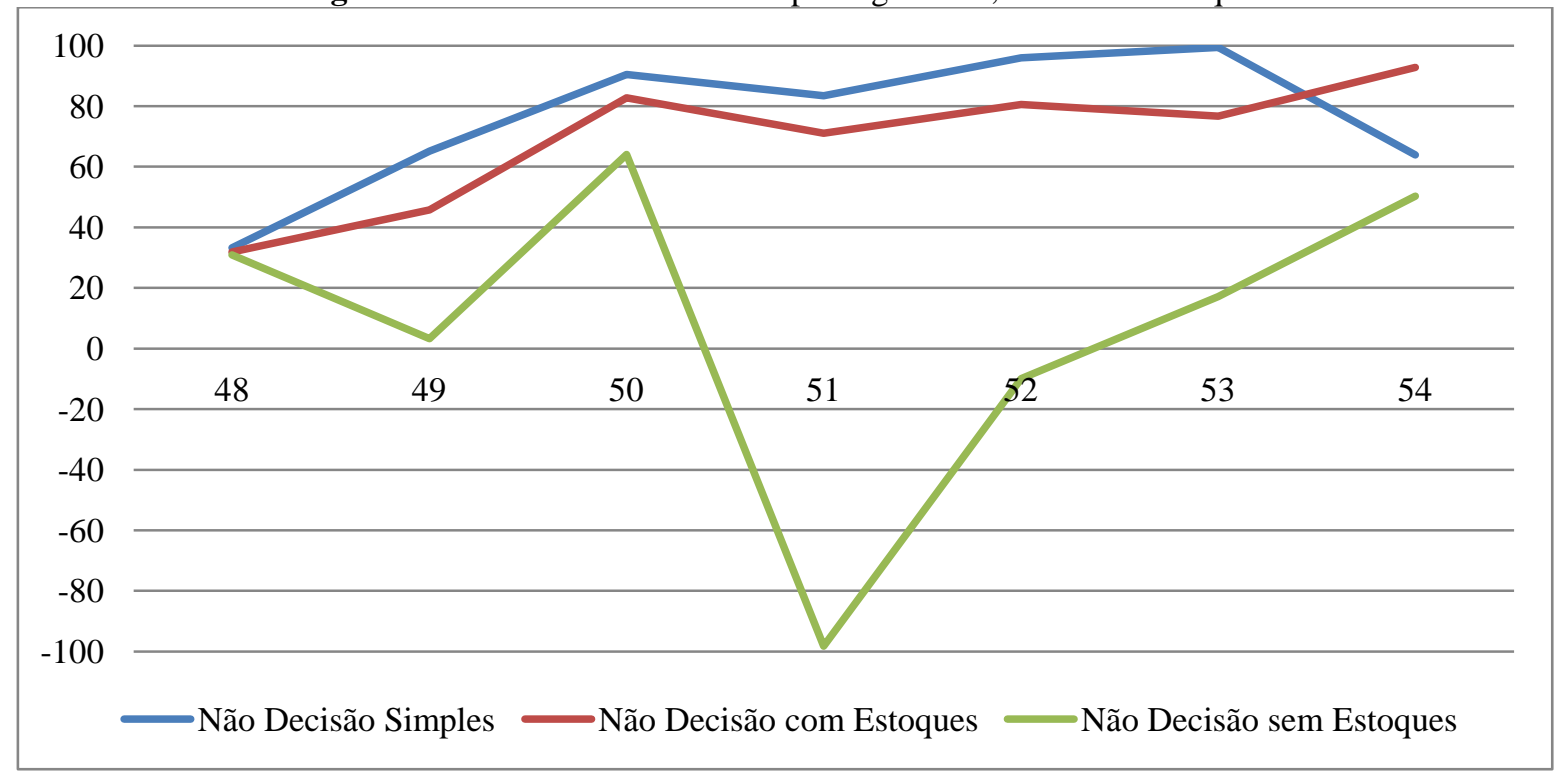

Fonte dos dados brutos: Sistemas de Informação do Senado Federal e da Câmara dos Deputados, Diário do Senado Federal e do Congresso Nacional; Relatório Anual da Presidência do Senado Federal.

Como se vê, em geral, a capacidade de decidir sobre a agenda de vetos foi reduzida pela interferência dos estoques, pois, ao mesmo tempo em que se verifica um percentual de mais de 80\% de não decisão, a não decisão sem estoques sempre esteve abaixo, atestando uma preferencia crescente das legislaturas por lidar com estoques “frios", relegando os vetos mais recentes, sobre os quais os conflitos eram possivelmente maiores. 
Figura 14: Gráfico de vetos: 1988-2014 - Emissões, Estoques e Resoluções.

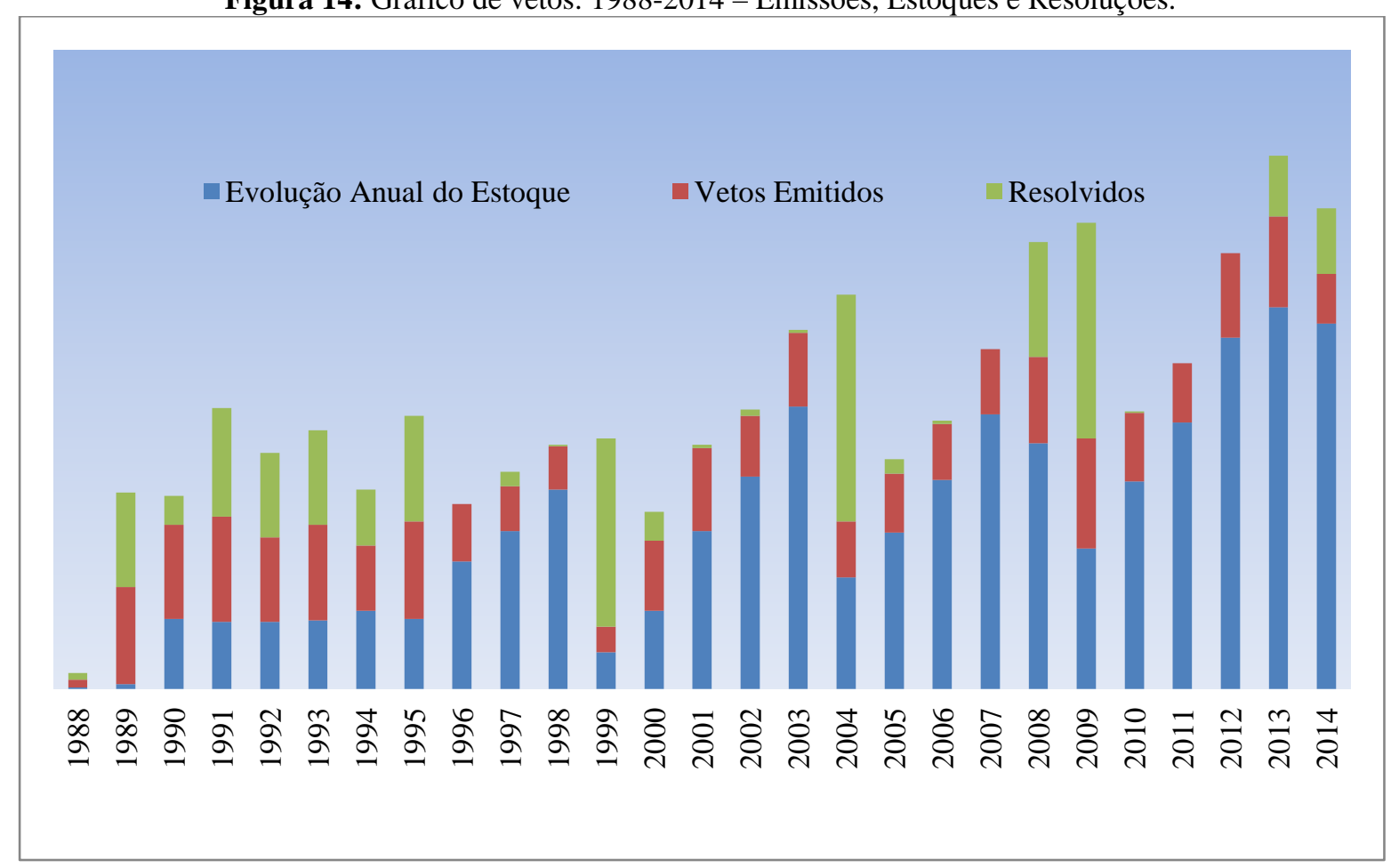

Fonte: Sistemas de Informação do Senado Federal e da Câmara dos Deputados, Diário do Senado Federal e do Congresso Nacional, Relatório Anual da Presidência do Senado Federal.

Evidencia-se na Figura 14 a dinâmica de emissão relativamente constante de vetos, resolução com rendimentos oscilantes, combinados com estoques crescentes, transferidos à legislatura seguinte. Como evidenciado, anos que apresentam uma elevada resolução de vetos, como 1999, 2004 e 2009 traduzem uma sistemática baseada em sessões raras, uso de cédula e vetos mantidos. A indisposição de deliberar sobre vetos traduz-se tanto em dificuldade de quórum $^{18}$, em um primeiro momento, de muitas sessões com baixo rendimento, quanto em raras sessões de veto, com alto rendimento, garantido pela cédula. Em qualquer dos casos, permanecia a transferência frequente de estoques e a manutenção dos vetos quando enfim apreciados.

Não se pode afirmar até aqui que a não decisão do Legislativo sobre os vetos tenha caráter absoluto de inércia. É possível concluir, no entanto, que os resultados indicam uma deliberação inócua sob o aspecto do conflito, o que induz o raciocínio de que o veto não explica muito o conflito de agendas entre Executivo e Legislativo, ao menos para o recorte temporal pesquisado.

\footnotetext{
${ }^{18}$ Ver explicação da Figura 16 do Apêndice sobre as dificuldades de quórum nas primeiras duas legislaturas.
} 
Pode-se falar em desinteresse, arena deserta, mas não se pode afirmar categoricamente que esse fato se deve unicamente ao interesse ou capricho dos estabelecedores de agenda.

Diante de comandos constitucionais translúcidos no tocante ao trancamento de pauta, a não decisão pode ser vista até mesmo como uma ação antiinstitucional, na medida em que supera, de forma radical, o obstáculo institucional oposto pelo legislador a si mesmo em 1988, característica das instituições, o que modifica o jogo de forças entre os atores constitucionais do processo legislativo, elevando com isso o grau de incerteza nas relações interinstitucionais (PETERS, 2012). 


\section{CONCLUSÃO}

Uma das principais dificuldades ao longo do caminho foi, ao reconhecer não haver decisão regular do Congresso sobre os vetos, lançar a questão da localização do conflito interpoderes para outras arenas, que não a do veto, algo que não pôde ser satisfatoriamente identificado. Ainda assim, os resultados alcançados enriquecem o debate acerca da não decisão, o poder de agenda negativo, e da obsolescência do veto no atual sistema politico brasileiro. As categorias desenvolvidas remetem aos aspectos específicos do processo decisório político e, nesse sentido, contribuem para o estudo do tema.

O conjunto de assunções teóricas foi complementado com um aporte empírico. Buscou-se avançar na compreensão do comportamento do Legislativo brasileiro nos primeiros 26 anos de vida constitucional no tocante a um instituto pretensamente indicador de conflito com o Executivo. A análise longitudinal permitiu captar os movimentos dos principais atores institucionais, ainda que sem seu testemunho direto, a partir da prospecção dos documentos legislativos.

Estudar o Poder Legislativo é tarefa complexa, como assinala Baaklini (1975), em reflexão sobre os estudos comparados de países em desenvolvimento. As dificuldades advêm, segundo o autor, da ordem técnica e também da ordem teórica da literatura. A principal dificuldade de ordem técnica, sentida durante a presente pesquisa, relaciona-se à informação legislativa, ao acesso a fontes que sejam mesmo tempo confiáveis, unificadas e de acesso facilitado. A principal característica negativa é a heterogeneidade dos dados, no modo como são organizados nos sítios oficiais dos órgãos legislativos, ou mesmo nos centros de pesquisa nacionais, não existindo uma fonte padronizada única.

A informação legislativa, formada a partir dos dados referentes aos debates, aos representantes e às matérias legislativas constitui um dos focos atuais de interesse da ciência política contemporânea. A ela dedicou-se a pesquisa da presente dissertação, mais especificamente ao processo legislativo formal do veto do Executivo, a partir da análise das regras constitucionais e regimentais, além dos usos e costumes consensuais de que se lançou mão. 
A complexidade das regras e procedimentos internos é frequentemente mencionada nos estudos legislativos. Uma das contribuições foi oferecer a descrição de um sistema concreto de decisões legislativas com ênfase nos resultados e nas regras e procedimentos adotados pelos atores institucionais, para que esses resultados fossem possíveis. Foi apreendido que o Legislativo inovou quando necessário, embora haja distinções entre as formas de inovação, e se tenha concluído que inovar procedimentos e regras alterou alguns resultados imediatos, mas não a tendência de não decidir.

Um efeito desse não decidir chama a atenção do analista: a mutação constitucional contra constitutionem. A reiterada desobediência ao prazo constitucional para apreciação dos vetos desde já constitui marca do comportamento constitucional do órgão legislador pós 1988. Procurou-se analisar o fenômeno sob a ótica da escolha racional, concluindo que o regime constitucional atual, herdeiro que é de um regime marcado pelo apagamento do Legislativo como órgão de decisão das políticas do Estado, traz como marca o Executivo como legislador de fato e um veto obsoleto, visto não responder mais pelas funções a ele atribuídas ao longo da história política. Mesmo os vetos rejeitados, tendo em vista sua distribuição temática e temporal, não traduziram a ordem de conflitos esperada para o instituto ${ }^{19}$.

O conceito de vetar deriva sua força da própria atividade política como prática humana. O poder de estatuir parece ter sido sempre acompanhado do poder de impedir. Isso não mudou, mas reafirma-se igualmente que o veto é um importante recurso institucional a serviço do Poder Executivo na formatação da legislação, conforme suas preferências. Por outro lado, o veto predominantemente parcial não suspensivo e não apreciado pelo Legislativo, combinado aos demais poderes legislativos constitucionais do Presidente da República faz dele o legislador de fato.

Ao mesmo tempo persiste a função de legitimação atribuída aos parlamentos e a titularidade do carimbo de democracia simbolizada pelo consenso político, em face de um conflito que é oportunizado pelas instituições, e fortemente mitigado pela prática dos atores políticos. Assim tem sido na arena do veto, hipótese confirmada pelos dados. Essa função

\footnotetext{
${ }^{19}$ Ver item 2.9 do Apêndice para o detalhamento do argumento referente aos vetos rejeitados.
} 
carimbadora tem como um de seus principais símbolos a cédula, com votações massivas de vetos, quase todos mantidos.

Cameron (2012) concorda que o veto pode nem chegar a ser o poder mais determinante nas mãos do Presidente, mas para grande parte da literatura, ele permite aferir o conflito (HEPSTER, 2012) entre os poderes Executivo e Legislativo na formação da legislação. No presente caso, porém, é possível concluir que o conflito praticamente não comparece à arena de veto, conclusão que nem mesmo os vetos rejeitados excetuam. Não se trata de considerar o instituto formal decadente. Ao contrário, as análises de Grohmann (2003), Lamounier (2005) e Moya (2005) corroboram a efetividade do veto como ferramenta do Executivo da formatação da legislação. O que se aponta é que o processo de veto, plenamente compreensível apenas quando analisada a dimensão da apreciação pelo Legislativo, revela uma intensa modulação no instituto, cujas funções prescritas pela história e pela teoria foram fortemente alteradas.

O embate entre poderes acerca do conteúdo da legislação pode ter sido deslocado para outras arenas. Prevalece a lógica da mobilização de tendência, das duas faces do poder. O que se poderia chamar ausência do conflito seria, portanto, a ocultação do conflito no processo decisório de veto, o que aponta a necessidade de se investigarem, entre outros, os conteúdos em vez de somente as formas. Exemplo disso são trabalhos como os de Ricci (2003), que apontam a possiblidade de um maior rendimento em análises dos conteúdos das políticas, aferidos por sua relevância conjuntural, em vez de se avaliações de pluralidades de projetos heterogêneos.

Uma variável mostrou-se muito significativa para justificar a omissão parcial do Congresso quanto ao veto: o tempo decisório, um dos núcleos do conceito de agenda. A agenda forçada, principal efeito do escopo constitucional inaugurado em 1988 sobre o decidir legislativo, é filha do regime autoritário, como restou evidenciado, e é justificada pelas exigências de velocidade do Estado Propulsor.

O Poder Legislativo, na figura de um Parlamento representativo das localidades geográficas, é crescentemente questionado, e um dos argumentos mais repetidos é o da lentidão decisória. O consenso lento, marca das decisões coletivas, não é bem visto. O conflito é quase incriminado, e os interesses são quase sempre traduzidos como negativos para o sistema. Contra as lições de Przeworski (1984), a incerteza democrática parece ser cada vez menos tolerada, e o 
foco preferencial dessa impaciência tem sido o tempo decisório do Poder Legislativo. Por essa razão, considera-se que a não decisão sobre vetos não pode ser vista tão somente como estratégia, pura mobilização de tendências, mas talvez como um fenômeno complexo que abriga também a mencionada discussão.

Uma das reflexões oportunizadas pela presente pesquisa diz respeito ao sistema de separação de poderes. A fusão das funções típicas dos poderes Legislativo e Executivo parece traduzir uma dificuldade dos regimes democráticos concretos atuais de corresponder aos purismos teóricos que valoram essa separação. Se o veto tende a ser inútil em uma separação sem contraste, como critica Casasanta (1937), o comportamento do Congresso brasileiro de 1988 a 2014 corrobora essa previsão. A função legisladora foi exercida de modo aglutinado, sob a batuta incontestada dos presidentes da República que, para estruturar suas coalizões, lotaram gabinetes com agentes políticos, muitos deles advindos diretamente das Legislaturas.

Ao mesmo tempo, se o veto tende à transposição de titularidade, como viu Britto (1966), vemos seu poder repousar sobre ombros presidenciais, com suspensividade não aproveitada pelo legislador, esse amálgama decisório formado por Executivo e Legislativo, na atualidade, para o bem ou para o mal, é o beneficiário do poder de veto no Brasil de hoje, e forja um novo sistema de separação de poderes, como o presente estudo permitiu concluir. Em termos de atores institucionais, pode-se afirmar que os titulares desse poder são tanto o Presidente da República, quanto o Presidente do Senado Federal, como Presidente do Congresso Nacional.

Em suas conclusões, Cameron (2000), depois de haver estudado as trocas (barganhas) entre Executivo e Legislativo, na legiferância com presença de vetos, em governos americanos divididos, termina por se questionar quanto à importância do sistema de separação dos poderes. Responde considerando que ele pode ser visto como um sistema essencialmente presidencial, mas em que se considera a importância da existência de dois ramos separados, cuja marca mais distinta são as trocas entre si. O presente estudo revela que, para o caso estudado, essas trocas não se deram à luz do processo decisório do veto, mas em jogos ocultos (TSEBELIS, 1998), a serem plenamente investigados.

Essa conclusão contribui para as conclusões de Grohmann (2003), com o conceito de apoio mútuo, e Lamounier (2005), com o de reciprocidade estratégica, ambos visando a melhor 
compreensão do sistema presidencialista brasileiro, com suas conhecidas especificidades, notadamente as interações que parecem ser marcadas pela prática dos jogos ocultos. Em comum entre essas conclusões está a constatação de que o sistema apresenta um desempenho superior ao esperado pela teoria, apesar das críticas.

Se as funções de magistratura (Poder Executivo) podem estar se confundindo com as funções da Legislatura (Congresso) desde 1787, nos Estados Unidos, ou desde 1824, no Brasil, formando um amálgama que visa principalmente facilitar a ação de governar, parece desarrazoada a perplexidade quanto aos seus efeitos, e é curioso que essas perplexidades gerem pressupostos de desequilíbrio como considerável parte da literatura científica tem preferido. O que salta aos olhos do analista é a percepção de que o modelo de decisão delineado não é aquele desenhado pelo constituinte de 1988 apenas, mas outro, forjado a partir de um comportamento que pode ser taxado de antiinstitucional, supressor de conflito e fortemente indicativo de um sistema político distinto de grande parte das prescrições teóricas vigentes.

Ao mesmo tempo, também é certo que na formação do gabinete do Executivo é comum a predominância de parlamentares, no exercício de mandato eletivo ou não, ocupando pastas ministeriais e comando de empresas públicas, verificando-se claramente o exercício indireto atípico de funções executivas por parte de membros do Legislativo. Santos (2006) avalia essa prática a partir da constatação de constante empenho dos Presidentes em formar gabinetes com sua coalizão eleitoral - mensurado por meio de um índice criado por Amorim Neto (2000), a chamada Taxa de Coalescência ${ }^{20}$. O autor nota que, apesar do esforço de formação de ministérios baseados nos partidos da eleição, a disciplina partidária garantida pela coalescência decresce ao longo do mandato e por vezes também em razão do distanciamento ideológico. A cooperação não seria dada, mas induzida por meio dos recursos partidários de agenda.

É frequente a preocupação dos estudiosos com a função de geração de conflitos, aparentemente desempenhada por algumas instituições democráticas, quando seriam mais aconselháveis instituições para regulá-los. Esses conflitos, aparentes ameaças ao sistema, são percebidos tanto nas colocações de Santos (2006) sobre a disciplina decrescente, mesmo com

\footnotetext{
${ }^{20}$ Indicador matemático que explica a relação entre cotas ministeriais (Gabinete) e peso parlamentar, relacionando a obtenção de cadeiras pelos votos obtidos na eleição com as pastas ministeriais.
} 
altas taxas de coalescência, quanto pelas presentes constatações sobre a ocorrência crescente de vetos, mesmo diante da forte capacidade legislativa do Executivo. O que não se pode afirmar é que o conflito seja gerado pela existência dessas instituições, mas talvez se possa reconhecer que elas são indicadoras de conflitos, em cuja natureza possivelmente se possam encontrar suas razões de surgimento e resolução.

Os resultados permitem fortalecer a conclusão de que o veto é, apenas teoricamente, indicador institucional de conflito entre poderes. O instituto reafirma a tendência de formação de amálgama decisório Magistratura-Legislatura, ao mesmo tempo em que se apresenta como poder reativo excedente para o Executivo, temporariamente deformado com referência às origens do instituto, em favor de uma governabilidade desejável, que por sua vez demanda uma efetividade legislativa.

O veto no Brasil de 1988 a 2014 auxilia na compreensão da fusão de funções entre os ramos de poder, e indica que o conflito provavelmente situa-se em outras arenas. A ideologia do receio de fusão, ou confusão de papéis entre poderes remonta ao Iluminismo e pode ser resumida ao receio de que haja perda da qualidade da democracia, pela perda da liberdade dos governos, tendo por pano de fundo o temor da tirania. O temido predomínio sem contrastes não parece ser necessariamente negativo, mas traz consigo reflexões sobre os efeitos de uma fusão tendente a escamotear conflitos de fundo social e histórico, além de produzir uma democracia de consensos ilegítimos, calcados em trocas ocultas, deslocadas dos pontos institucionais de sua ocorrência.

Montesquieu (p. 78) assinalava que "O poder executivo [...] deve tomar parte na legislação por meio de sua faculdade de impedir, sem a qual será logo despojado de suas prerrogativas. Mas se o Poder Legislativo participa da execução, o Executivo será igualmente perdido.” O aspecto curioso da leitura desse pequeno trecho do Espírito das Leis é que, no momento atual, a vida dos Estados democráticos de direito contemporâneos é marcada pela infusão institucional. Uma mistura de funções e papéis em que o presidencialismo produz acordos de agenda baseados na formação do gabinete com elementos advindos predominantemente do Legislativo. Ou seja, tanto o Executivo prevalece na função legislativa, quanto o legislativo participa da função executiva na formação dos ministérios, ainda que contra as lições de prudência do mestre francês. 
Figueiredo e Limongi (2004) abordam a análise de tipologias dos Legislativos desenhadas por Polsby e por Cox e Morgenstein. Essencialmente, a literatura científica tende a tipificar os Legislativos presidencialistas com pressupostos a partir dos quais são definidos os caracteres de cada tipo. Esses traços dizem respeito às consequências de se extremarem a noção de separação dos poderes e autonomia legiferante. O paradigma norte-americano de presidencialismo ainda predomina na formação de tipologias, o que talvez indique o porquê dos vieses das análises sobre os sistemas presidencialistas da América Latina.

Os autores propõem uma tipificação própria, ressaltando, de início, seu forte aspecto de centralização sobre as figuras da Mesa e dos Líderes partidários, bem como da aceleração da tramitação mediante ritos de urgência entre outros procedimentos. Diante de um Executivo legislador, no sentido tanto da iniciativa quanto do momento, prevalece a reserva de competência da maioria coordenada. Essa coordenação é impulsionada pela formação do Gabinete (Ministérios e empresas públicas). Embora se tenha tentado evitar a leitura dos dados enviesada pela normatividade das tipificações, reconhece-se seu claro valor heurístico. Elas parecem revelar tanto as características comparáveis dos legislativos quanto expor a mentalidade por trás dos critérios geradores das comparações.

Outro proveito teórico obtido, ainda que não de modo direto, diz respeito aos partidos, “[...] a carne e o sangue da Constituição” (WHEARE, p. 81). É corrente a discussão sobre a substituição dos parlamentos representativos pelos partidos políticos ${ }^{21}$, que são, a um só tempo, responsabilizados pelo enfraquecimento dos parlamentos e tidos por garantidores de sua permanência, notadamente nos regimes latinoamericanos, em que é comum a centralização decisória em ambiente fragmentado, operacionalizando um desenho institucional tido por complexo e dispendioso. Foi possível perceber, ainda que perifericamente, ao longo da pesquisa, a relevância dessa categoria analítica para as pesquisas futuras sobre a separação dos poderes e sobre a importância e sobrevivência dos parlamentos, ilustrada pela onipresença do PMDB na presidência do Congresso Nacional.

O presente estudo tentou responder a uma provocação: dado que o Congresso, mesmo inovando procedimentos e regras, não decide sobre o veto, seria ele um instituto obsoleto? Partiu-

\footnotetext{
${ }^{21}$ Ver a respeito o Quadro 8, no Apêndice, que ilustra as presidências do Congresso Nacional.
} 
se da origem histórica do instituto, seu emprego ao longo da história nos diversos sistemas políticos que influenciaram o atual sistema brasileiro, para averiguar afirmações como a de Casasanta (1937), de que "quer no fascismo, quer no parlamentarismo, o veto será uma inutilidade, porque o predomínio sem contraste de um poder lhe tira a razão de ser.” (p. 320). A reposta obtida é parcialmente afirmativa, como restou comprovado. O comportamento do Congresso Nacional no período estudado inutiliza e deforma o instituto, ao menos temporariamente, e consequentemente modifica o sistema político, visto tratar-se de instituto central ao freio e contrapeso na formação da lei.

Conclui-se que o veto atual do sistema político pátrio não é veto no sentido que lhe conferiu a história, consideradas suas raízes institucionais e o trato deliberativo concreto dado pelo Congresso Nacional. Trata-se, de fato e de direito, de instituto diverso daquele surgido em Roma, ou mesmo daquele consagrado pela Constituição dos Estados Unidos. Foi exercido fartamente pelo Executivo, e não foi apreciado pelo Legislativo (exceto talvez em casuísmos, como último recurso). Revelou-se, segundo análise que considerou exercício de vetar e de apreciar vetos, uma adaptação às exigências contemporâneas do tempo decisório político, expresso em uma espécie de emenda supressiva, cuja superação é seriamente dificultada pelo quórum constitucional para rejeição, bem como deslocou o conflito na formação da lei para outros locais, a serem ainda plenamente investigados.

A presença do ramo legislativo tem operado como um indicador do surgimento dos regimes democráticos calcados no Estado de Direito. Talvez por essa razão os estudos legislativos ganhem cada vez mais espaço na ciência política. As reflexões proporcionadas vêm somar-se, entretanto, à discussão acerca do declínio desse poder. Em um momento em que se chega a falar em “democracia pós-parlamentar” (RICHARDSON E JORDAN, 1979 apud MARTIN, SAALFELD E STROM, 2014, p. 16), faz-se necessário compreender as decisões dos legislativos, seus procedimentos internos e suas aparentes inoperâncias.

O veto no sistema político brasileiro desenhado pela Constituição de 1988, ainda que aparente seja um instituto juspolítico decadente, tendente à obsolescência, e causador da inversão da reatividade do Executivo para Legislativo, ainda é uma variável relevante para explicar aspectos essenciais dos sistemas políticos baseados na separação dos poderes que, no entanto, permitem que o poder de legislar seja exercido com a participação dos dois poderes, sob a batuta 
do Chefe do Poder Executivo, com as bênçãos dos principais atores do Legislativo, portador de uma titularidade cada vez mais ameaçada.

Tratou-se aqui de avançar na compreensão de um processo decisório político-legislativo, levando em conta o percurso histórico das instituições que o ordenam, mediante a ação concreta dos poderes de sobre elas dispor, tendo por baliza a consciência sobre os ideais por trás da ação humana. Os resultados obtidos confirmaram a suposição inicial de que, apesar das concepções ideais dos sistemas políticos, cujo desiderato último parece ser a justiça (bandeira perene dos sonhadores democráticos), há que se compreender melhor os modelos forjados da experiência histórica, construída com a prática e que, no caso do veto brasileiro, têm muito a acrescentar aos modelos e suas concepções. 


\section{REFERÊNCIAS}

ABRANCHES, Sérgio. Presidencialismo de Coalizão: o dilema institucional brasileiro. In: Dados - Revista de Ciências Sociais, vol. 31, n. 1, 1988, p. 5-34.

ALECRIM, Otacílio. O sistema de vetos nos Estados Unidos e a receptividade brasileira. Rio de Janeiro: Instituto Pró- Memória de Macaíba, 2008. 2. Ed.

ALEMAN, Eduardo, SCHWARTZ, Thomas. Presidential Vetoes in Latin American Constitutions. In: Journal of Theoretical Politics, N.18. p. 98-120. Houston: University of Houston, 2006.

AMORIM NETO, Octavio. Gabinetes presidenciais, ciclos eleitorais e disciplina legislativa no Brasil. Dados [online]. 2000, vol.43, n.3 [cited 2015-10-26], pp. 479-519 . Disponível em: < http://www.scielo.br/scielo.php?script=sci_arttext\&pid=S0011-

52582000000300003\&lng=en\&nrm=iso\%20-\%20back >. Acesso em 26/10/2015. 14h22.

AMORIM NETO, Octavio; TAFNER, Paulo. Governos de Coalizão e Mecanismos de Alarme de Incêndio no Controle Legislativo das Medidas Provisórias. In: DADOS - Revista de Ciências Sociais, 45, 1: 5-38. 2002.

AMORIM NETO, Octávio; COX, Gary W; MCCUBBINS, Mathew D. Agenda power in Brazil’s Câmara dos Deputados. In: World Politics. Princeton, n. 55, p. 550-578, jul. 2003

BAAKLINI, Abdo. Legislatures in Contemporary Society. Nova York: State University of New York at Albany, 1975.

BACRHACH, Peter;BARATZ, Morton. Two Faces of Power. Revista The American Political Science Review. Vol. 56, Issue 4, Dezembro 1962, p. 947-952. Disponível em <http://www.columbia.edu/itc/sipa/U6800/readings-sm/bachrach.pdf>. Acesso em 5 mai. 2013.

BACRHACH, Peter;BARATZ, Morton. Decisions and nondecisions. Revista The American Political Science Review. Vol. 57, Issue 3, setembro de 1963, p. 632-642.

BENNETT, A. Case Study Methods: Design, Use, and Comparative Advantages. In: Cases, Numbers, Models: International Relations Research Methods. Michigan: The University of Michigan Press, 2004. Disponível em <https://minorthesis.files.wordpress.com/2012/12/andrew-bennet-case- 
study.pdf>, acesso em 25/10/2015. 15 .

BITTENCOURT, Fernando M. R. Relações Executivo-Legislativo no Presidencialismo de Coalizão: um quadro de referência para estudos de orçamento e controle. Textos para discussão, 112, abril/2012. Brasília: Senado Federal, 2012.

BRAGA, Ricardo de João. O Processo Decisório Legislativo na Criação e Reforma do Bacen e do CMN em 1964 e 1994: incerteza, cooperação e resultados legislativos. Tese (Doutorado em Ciência Política). Universidade do Estado do Rio de Janeiro, Rio de Janeiro, 2011. Disponível em: http://bd.camara.gov.br/bd/handle/bdcamara/9928>. Acesso em 18 maio 2013.

BRASIL. Congresso Nacional. Regimento Comum: Resolução n. 1, de 1970-CN. Disponível em $<$ http://www.senado.gov.br/legislacao/regsf/RegComum_Normas_Conexas.pdf $>$. Acesso em 31 de outubro de 2015.

. Constituição (1988). Constituição da República Federativa do Brasil. Disponível em: $<$ http://www.planalto.gov.br/ccivil_03/constituicao/constitui\%C3\%A7ao.htm>. Acesso em 31/10/2015.

. Constituição (1988a). Constituição da República Federativa do Brasil (compilada). Disponível em: <https://www.planalto.gov.br/ccivil_03/constituicao/constituicao.htm>. Acesso em 31/10/2015.

. Congresso Nacional. Regimento interno da Câmara dos Deputados: Resolução n. 17, de 1989. Disponível em < http://www2.camara.leg.br/atividade-legislativa/legislacao/regimentointerno-da-camara-dos-deputados $>$. Acesso em 3/11/2015.

. Congresso Nacional. Sessão Plenária de 4 de abril de 1989. Diário do Congresso Nacional. Brasília: Ano XLIV, n. 30, 6 de abril de 1989, p. 964. Disponível em: < http://legis.senado.gov.br/diarios/BuscaDiario?datSessao=04/04/1989\&tipDiario=2>. Acesso em 31/10/2015.

. Congresso Nacional. Sessão Plenária de 28 de novembro de 1989. Diário do Congresso Nacional. Brasília: Ano XLIV, n. 98, 29 de novembro de 1989, p. 4995. Disponível em: < http://legis.senado.gov.br/diarios/BuscaDiario?datSessao=28/11/1989\&tipDiario=2>. Acesso em: 31/10/2015. 
. Congresso Nacional. Sessão Plenária de 26 de junho de 1990. Diário do Congresso Nacional. Brasília: Ano XLV, n. 51, 27 de junho de 1989, p. 3376. Disponível em: < http://legis.senado.gov.br/diarios/BuscaDiario?datSessao=26/06/1990\&tipDiario=2>. Acesso em: 31/10/2015.

. Congresso Nacional. Sessão Plenária de 14 de maio de 1992. Diário do Congresso Nacional. Brasília: Ano XLVII, n. 15, 15 de maio de 1992. Disponível em: < http://legis.senado.gov.br/diarios/BuscaDiario?datSessao=14/05/1992\&tipDiario=2>. Acesso em: $31 / 10 / 2015$.

. Congresso Nacional. Sessão Plenária de 20 de maio de 1992. Diário do Congresso Nacional. Brasília: Ano XLVII, n. 16, 21 de maio de 1992, p. 625. Disponível em: < http://legis.senado.gov.br/diarios/BuscaDiario?datSessao=20/05/1992\&tipDiario=2>. Acesso em: 31/10/2015.

. Congresso Nacional. Sessão Plenária de 12 de agosto de 1997. Diário do Congresso Nacional. Brasília: Ano LII, n. 018, 13 de agosto de 1997, p. 6025. Disponível em: $<$ http://legis.senado.gov.br/diarios/BuscaDiario?datSessao=12/08/1997\&tipDiario=2>. Acesso em: 31/10/2015.

Lei complementar n. 95, de 26 de fevereiro de 1998. Dispõe sobre a elaboração, a redação, a alteração e a consolidação das leis, conforme determina o parágrafo único do art. 59 da Constituição Federal, e estabelece normas para a consolidação dos atos normativos que menciona. Disponível em: <http://www.planalto.gov.br/ccivil_03/leis/lcp/lcp95.htm>. Acesso em: 3/11/2015.

Congresso Nacional. Sessão Plenária de 15 de setembro de 1999. Diário do Congresso Nacional. Brasília: Ano LIV, n. 025, 16 de setembro de 1999, p. 13.250. Disponível em: < http://legis.senado.gov.br/diarios/BuscaDiario?datSessao=15/09/1999\&tipDiario=2>. Acesso em: 5/11/2015.

Congresso Nacional. Câmara dos Deputados. Projeto de Lei (PL) n. 1270, de 2007. Disponível em $<$ http://www2.camara.leg.br/proposicoesWeb/fichadetramitacao?idProposicao=354397>. Acesso em 3/11/2015.

Congresso Nacional. Sessão Plenária de 9 de fevereiro de 2010. Diário do Congresso Nacional. Brasília: Ano LXV, n. 004, 10 de fevereiro de 2010. Disponível em: < 
http://legis.senado.gov.br/diarios/BuscaDiario?datSessao=09/02/2010\&tipDiario=2>. Acesso em: 3/11/2015.

. Congresso Nacional. Veto Parcial n. 11 de 2010. Disponível em $<$ http://www.congressonacional.leg.br/portal/veto/3392>. Acesso em 3/11/2015.

Congresso Nacional. Sessão Plenária de 10 de maio de 2011. Diário do Senado Federal. Brasília: Ano LXVI, n. 072, 11 de maio de 2011. Disponível em: < http://legis.senado.gov.br/diarios/BuscaDiario?datSessao=10/05/2011\&tipDiario=1>. Acesso em: 5/11/2015.

Disponível

Congresso Nacional. Ordem do dia da Sessão Conjunta de 11 de maio de 2011. em:

http://www.senado.gov.br/atividade/plenario/ordemdodia/default.asp?casa=CN\&div=66\&data=1 0/11/2015\#/divisao/CN/66/10/11/2015>. Acesso em: 10/11/2015.

_. Anais da Assembleia Nacional Constituinte. Disponivel em < http://www2.camara.leg.br/atividadelegislativa/legislacao/Constituicoes_Brasileiras/constituicao-cidada/publicacoes/anais-daassembleia-nacional-constituinte>, acesso em 11/8/2015.

Disponível

Congresso Nacional. Ordem do dia da Sessão Conjunta de 19 de dezembro de 2012. http://www.senado.gov.br/atividade/plenario/ordemdodia/default.asp?casa=CN\&div=66\&data=1 0/11/2015\#/divisao/CN/66/10/11/2015>. Acesso em: 10/11/2015.

Supremo Tribunal Federal. Mandado de Segurança n. 31.816. Liminar Ministro Luiz Fux de 18/12/2012. Disponível em $<$ http://www.stf.jus.br/portal/processo/verProcessoAndamento.asp?incidente=4345967>, acesso em 5/11/2015.

. Congresso Nacional. Resolução n. 1, de 2013-CN. Altera a redação dos arts. 104 a 106 da Resolução n ${ }^{\circ}$ 1, de 1970-CN, que dispõe sobre o Regimento Comum do Congresso Nacional. Disponível em < http://www2.camara.leg.br/legin/fed/rescon/2013/resolucao-1-11-julho-2013776491-norma-pl.html>, acesso em 12/11/2015.

. Emenda Constitucional n. 76, de 2013, de 28 de novembro de 2013. Altera o $\S 2^{\circ}$ do art. 55 e o $\S 4^{\circ}$ do art. 66 da Constituição Federal, para abolir a votação secreta nos casos de perda de mandato de Deputado ou Senador e de apreciação de veto. Disponível em 
<http://www.planalto.gov.br/ccivil_03/constituicao/emendas/emc/emc76.htm>, acesso em 3/11/2015.

BRITTO, Luis Navarro de. O veto legislativo: um estudo comparado. Distrito Federal: Ministério da Justiça, 1966.

BULOS, Uadi Lamêgo. Costume Constitucional. Revista de Informação Legislativa, v. 33, n.

CAMERON, Charles M. 2000. Veto bargaining: presidents and the politics of negative power. New York: Cambridge University Press.131, p.95-107, jul./set. 1996. Brasília: Senado Federal, 1996.

CARDOZO, José Eduardo. A crise do Legislativo. In: Estudos Avançados. São Paulo: [online]. Vol.23, n.67, p. 79-87. 2009. Disponível em <http://www.scielo.br/scielo.php?pid=S010340142009000300008\&script=sci_arttext>, acesso em 15/09/2015.

CAREY, John, SHUGART, Mathew. Presidents and Assemblies: Constitutional Design and Electoral Dynamics. New York: Cambridge University Press, 1992.

CASAGRANDE, Renato e FREITAS FILHO, Roberto. O Problema do Tempo Decisório nas Políticas Públicas. In: Revista de Informação Legislativa. Brasília, ano 47, n. 187, julho/setembro 2010, p. 21-34

CASASANTA, Mário. O poder do veto. Belo Horizonte: Ed. Os Amigos do Livro. 1937. (Tese de concurso).

CONSTANT, Benjamin. Cours de politique constitutionnelle: ou, collection des ouvrages publiés sur le gouvernement représentativ. 2. ed. Paris: 1872. Disponível em <https://archive.org/stream/coursdepolitique01consuoft\#page/n5/mode/2up>, acesso em 05/08/2015.

COX, G W. The organization of democratic legislatures. In: WEINGEIST, B.R.; WITTMAN, D.A. The Oxford handbook of political economy. Oxford: Oxford University Press, 2006, p. 141161.

COX, G. W; McCUBBINS, M. D. Legislative Leviathan: party government in the House. Berkeley, Los Angeles, London: University of California. 1993. 
DA CUNHA FERRAZ, Anna Cândida. Processos informais de mudança da Constituição: mutações constitucionais e mutações inconstitucionais. M. Limonad, 1986.

DELLEY, Jean-Daniel; FLÜCKIGER, Alexandre. A Elaboração Racional do Direito Privado: da codificação à Legística. Cadernos da Escola do Legislativo, Belo Horizonte, v.9, n.14, p. 3558, jan./dez. 2007.

FERREIRA FILHO, Manoel Gonçalves. Do Processo Legislativo. $5^{\text {a }}$ ed. São Paulo: Saraiva, 2002.

FERREIRA JÚNIOR, N.A.; PERLIN, G.D.B.;ROCHA, A.B. Reforma política no parlamento brasileiro: considerações a partir da rejeição política do projeto de lei 1210 de 2007. E-legis, Brasília, n. 9, p. 24-51, $2^{\circ}$ semestre 2012.

FIGUEIREDO, A. C.. Instituições e Política no Controle do Executivo. Dados. Rio de Janeiro, v. 44, n. 4, 2001.4 Disponível $<$ http://www.scielo.br/scielo.php?script=sci_arttext\&pid=S0011$52582001000400002 \& \operatorname{lng}=\mathrm{en} \& n r m=\mathrm{iso}>$. Acesso 5 maio 2013.

FIGUEIREDO, Argelina Cheibub; LIMONGI, Fernando. Executivo e Legislativo na nova ordem constitucional. Rio de Janeiro: Editora FGV, 1999.

Modelos de Legislativo: o legislativo brasileiro em perspectiva comparada. Plenarium - Revista da Câmara dos Deputados, n. 1, 2004. p. 41-56.

Poder de agenda na democracia brasileira: desempenho do governo no presidencialismo pluripartidário. In: SOARES, Gláucio Ary Dillon; RENNÓ, Lucio R. Reforma política: lições da história recente. Rio de Janeiro: Fundação Getúlio Vargas, 2006.

Poder de agenda e políticas substantivas. In: Legislativo brasileiro em perspectiva comparada. Belo Horizonte: UFMG, 2009. p. 77-104.

GERRING, John. Social science methodology: a unified framework. Cambridge University Press, 2012. 
GOMES, F. B. C. Interações entre o Legislativo e o Executivo Federal do Brasil na Definição de Políticas de Interesse Amplo: uma abordagem sistêmica, com aplicação na saúde. Tese. (Doutorado em Sociologia e Ciência Política). Rio de Janeiro: Universidade Estadual do Rio de Janeiro, 2011. Disponível em: < http://bd.camara.gov.br/bd/handle/bdcamara/6165>. Acesso em: 5 maio 2013.

GROHMAN, Luis Gustavo Mello. O veto presidencial no Brasil: 1946-1964 e 1990-2000. 2003. 269 f. Tese (Doutorado em Ciências Humanas: Ciência Política) - Instituto Universitário de Pesquisas do Rio de Janeiro (IUPERJ). IUPERJ, Rio de Janeiro.

HETSPER, Rafael Vargas. O Poder de veto no ordenamento jurídico brasileiro. Revista de Informação Legislativa. Brasília, n. 193, p. 215-226, jan/mar. 2012.

HELMKE, Gretchen e LEVISTSKY. Informal Institutions and Comparative Politics: a research agenda. (Working Paper). Kellogg Institute for International Studies, 2003. Disponível em <http://kellogg.nd.edu/publications/workingpapers/WPS/307.pdf>. Acesso em: 18 maio 2013.

INDRIDASON, Indridi $H$. Executive veto power and credit claiming: comparing the effects of the line-item veto and the package veto. In: Public Choice. v. 146. p. 375-394. 2011. Disponível em <http://link.springer.com/article/10.1007\%2Fs11127-010-9595-8>, acesso em 29/09/2015.

LAMOUNIER, Leonardo Alves. Poder de Agenda, poder de veto e relações ExecutivoLegislativo no Brasil contemporâneo: presidencialismo de coalizão e reciprocidade estratégica. 2005. 211 f. Tese (Doutorado em Ciências Humanas: Sociologia e Ciência Política) - Faculdade de Filosofia e Ciências Humanas da UFMG. Universidade Federal de Minas Gerais (UFMG), Minas Gerais.

LIMONGI, Fernando. A Democracia no Brasil: Presidencialismo, coalizão partidária e processo decisório. In: Revista Novos Estudos. São Paulo: Cebrap, n. 76, p. 17-41, 2006.

LIJPHART, Arend. Comparative Politics and the Comparative Method. American Political Science Review, n. 65 (2), p. 682-693, 1971. Disponível em <http://dcpis.upf.edu/ raimundoviejo/docencia/girona/Lijhardt.pdf>, acesso em 25/10/2015. 15 h.

MARTIN, Shane; SAALFELD, Thomas; STRØM, Kaare W. (Ed.). The Oxford Handbook of Legislative Studies. Oxford University Press, 2014. 
MARTINS, Ricardo C. R. O Poder Legislativo e as políticas públicas educacionais no período 1995-2010. Tese (Doutorado em Ciência Política) - IESP/CEFOR, Universidade do Estado do Rio de Janeiro, Rio de Janeiro/Brasília, 2011.

MASON, E. The Veto Power: its origins, development and function in the government of the United States (1789-1889). Boston: Harvard University Press, 1891. Disponível em < https://archive.org/stream/vetopoweritsorig00masouoft\#page/n5-/mode/2up >, acesso em 19/9/2014.

MENEGUin, F. B.; MAGNA, I. Desempenho do Poder Legislativo: como avaliar? Brasília: Núcleo de Estudos e Pesquisas/CONLEG/Senado, Setembro/2014 (Texto para Discussão n ${ }^{\circ} 155$ ). Disponível em: <www.senado.leg.br/estudos>. Acesso em 22 Out. 2015

MONTESQUIEU. Espírito das Leis. Disponível em $<$ http://www.dhnet.org.br/direitos/anthist/marcos/hdh_montesquieu_o_espirito_das_leis.pdf $>$, acesso em 05/08/2015.

MOYA, Maurício Assunção. Executivo versus Legislativo: os vetos presidenciais no Brasil (1988-2000). 2005. 170 f. Tese (Doutorado em Ciência Política) - Faculdade Filosofia, Letras e Ciências Humanas da USP. Universidade de São Paulo (USP), São Paulo.

MÜLLER, Wolfgang C.; SIEBERER, Ulrich. Procedures and rules in legislatures. In:MARTIN, Shane; SAALFELD, Thomas; STRØM, Kaare W. (Ed.). The Oxford Handbook of Legislative Studies. Oxford University Press, 2014, cap. 15.

NICOLAU, Jairo. Eleições no Brasil: do império aos dias atuais. Rio de Janeiro: Zahar, 2012.

NORTON, Philip. Parliament in brittish politics. London: Palgrave Macmillan, 2013. Disponível em $<$ https://books.google.com.br/books?id=kEEdBQAAQBAJ\&pg=PA296\&lpg=PA296\&dq=parlia ment+in+british+politics+pdf\&source=bl\&ots=SDOTliuhBx\&sig=rDLJ3sdjZ7JkMVH3Z2pB2R E0M-4\&hl=pt-BR\&sa=X\&ved=0CDsQ6AEwBGoVChMIh6wu6WEyQIVwYOQCh3ETgx5\#v=onepage\&q\&f=false>, acesso em 09/11/2015.

OST, François. O Tempo do Direito. Tradução Elcio Fernandes. São Paulo: Editora Universidade do Sagrado Coração, 2005.

PALERMO, V.. Como se governa o Brasil? O debate sobre instituições políticas e gestão de governo. Dados. Rio de Janeiro, v. 43, n. 3, 2000. Disponível em: 
$<$ http://www.scielo.br/scielo.php?script=sci_arttext\&pid=S0011-

52582000000300004\&lng=en\&nrm=iso>. Acesso em: 5 maio 2013.

PEREIRA, Carlos, POWER, Timothy e RENNÓ, Lúcio. Agenda Power, Executive Decree Authority, and the Mixed Results of Reform in the Brazilian Congress. In: Legislative Studies Quarterly. Volume XXXIII. Número 1. Iowa: Comparative Legislative Research Center of The University of Iowa, 2008. p. 5-33.

PEREIRA, Marcos Aurélio. Desenho organizacional e sua influência sobre o processo decisório de veto presidencial. E-Legis - Revista Eletrônica do Programa de Pós-Graduação da Câmara dos Deputados, Brasília, 13, abr. 2014. Disponível em: <página fora do ar>. Acesso em: 25 Set. 2012.

PESSANHA, Charles. Relações entre os Poderes Executivo e Legislativo no Brasil: 19461994. Tese de Doutorado. São Paulo: Universidade de São Paulo, 1997.

PETERS, Guy B. Institutional Theory in Political Science: The New Institutionalism. New York: Continuum, 2012. Cap. 10.

POLSBY, Nelson W. Legislatures. In: Legislatures in Contemporary Society. Nova York: University of New York in Albany: 1975. p. 257-319.

OLIVETTI, Nino. Processo legislativo. In: BOBBIO, N; MATTEUCCI, N.; PASQUINO, J. Dicionário de Política. Brasília: Ed. UnB, 1998. p.996.

PRZEWORSKI, Adam. Ama a incerteza e serás democrático. Novos Estudos CEBRAP, São Paulo, n. 9, p. 36-46, julho 1984.

RASCH, Bjørn Erik. Institutional Foundations of Legislative Agenda-Setting. In: MARTIN, Shane; SAALFELD, Thomas; STRØM, Kaare W. (Ed.). The Oxford Handbook of Legislative Studies. Oxford University Press, 2014.

RICCI, Paolo. O Conteúdo da produção legislativa brasileira: leis nacionais ou políticas paroquiais? In: Dados, Rio de Janeiro, v.46, n.4, 2003.

RIKER, William H. The theory of political coalitions. Yale: Yale University Press, 1962. 
RODRIGUES, Ernesto. O veto no direito comparado. São Paulo: Editora Revista dos Tribunais, 1993.

RUDALEVIGE, Andrew. Managing the president's program: presidential leadership and legislative policy formulation. Princeton: Princeton University Press, 2002. Capítulo 1 Disponível $<$ https://books.google.com.br/books?id=GqpKaNhQ59AC\&printsec=frontcover\&dq=rudalevige \&hl=pt-

BR\&sa=X\&ved=0CCUQ6AEwAWoVChMIvPuByqmEyQIVg4yQCh1EVAFU\#v=onepage\&q $\& f=$ false $>$, acesso em 09/11/2015.

SANTOS, Fabiano. Patronagem e Poder de Agenda na Política Brasileira. In: DADOS Revista de Ciências Sociais. N. 40. p. 465-492, 1997.

. Governos de coalizão no sistema presidencial: o caso do Brasil sob a égide da Constituição de 1988. In: AVRITZER, Leonardo; ANASTASIA, Fátima. Reforma Política no Brasil. Belo Horizonte: Editora UFMG, 2006.

SANTOS, Manoel. Teoria e método nos estudos sobre o Legislativo Brasileiro: uma revisão da literatura no período 1994-2005. In: Revista Brasileira de Informação Bibliográfica em Ciências Sociais BIB, n. 6. São Paulo: Associação Nacional de Pós-Graduação e Pesquisa em Ciências Sociais (ANPOCS), 2008.

SARTORI, Giovanni. Engenharia constitucional: como mudam as constituições. Tradução Sérgio Bath. Distrito Federal: Ed. Universidade de Brasília, 1996.

SCHATTCSHNEIDER, E. E. Intensity, visibility, direction, and scope. The American Political Science Review. Vol LI, December 1957, n. 4. Wesleyan University, 1957. p.933-942.

SCHWARTZ, Bernard. Los poderes del gobierno: comentário sobre la constitución de los Estadis Unidos.V.II. México (DF): UNAM (Universidad Nacional Autónomade México), 1966.

SILVA, José Afonso da. Processo constitucional de formação das leis. 2. ed. São Paulo: Malheiros, 2007.

SPITZER, Robert J. The constitutionality of the presidential line-item veto. In: Political Sience Quarterly. Volume 112. Número 2 (Summer). New York: The Academy of Political Science, 1997. p. 261-283. 
TSEBELIS, George. Jogos Ocultos: escolha racional no campo da política comparada. Tradução Luiz Paulo Rouanet. São Paulo: Ed. Universidade de São Paulo, 1998.

. Poder de veto: como funcionam as instituições políticas. Tradução Micheline Christophe. São Paulo: Ed. Fundação Getúlio Vargas, 2009.

VIEIRA, Fernando Sabóia. Poderes e atribuições do presidente da Câmara dos Deputados no processo decisório legislativo. In: Além das Urnas: reflexões sobre a Câmara dos Deputados. Brasília: Câmara dos Deputados, Edições Câmara, 2011. p. 93-120.

WEAVER, R. Kent; ROCKMAN, Bert A.. When and how do institutions matter? In: WEAVER, R. Kent; ROCKMAN, Bert A. Editores. Do institutions matter? Government capabilities in the United States and abroad. Brookings Institution Press, 1993.

WHEARE, K. Las Constituciones Modernas. Barcelona: Nueva Colección Labor, 1975. 


\section{APÊNDICE: RESULTADOS E INVENTÁRIO}

Para efeitos de uma contextualização dos dados relativos ao veto, atualiza-se o quadro de Grohmann (2003), que por sua vez atualizou as variáveis de Navarro de Britto (1966) quanto ao veto: tempo de governo, produção legislativa e emissão de vetos (Tabela 7). O quadro permite a comparação entre os dois períodos democráticos, anterior e posterior ao Regime Militar 19641985.

Tabela 7: Leis e Vetos - Primeiro e Segundo Períodos Democráticos

\begin{tabular}{|l|c|c|c|c|c|c|c|}
\hline \multicolumn{1}{|c|}{ PRESIDENTE } & $\begin{array}{c}\text { Duração } \\
\text { do } \\
\text { Mandato } \\
\text { (dias) }\end{array}$ & $\begin{array}{c}\mathbf{N}^{\mathbf{0}} \text { Leis } \\
\text { Promulgadas }\end{array}$ & $\begin{array}{c}\text { Total } \\
\text { de } \\
\text { Vetos }\end{array}$ & $\begin{array}{c}\mathbf{N}^{\mathbf{0}} \text { Vetos } \\
\text { Parciais }\end{array}$ & $\begin{array}{c}\text { \% Vetos } \\
\text { Parciais }\end{array}$ & $\begin{array}{c}\text { \% de } \\
\text { Vetos } \\
\text { sobre Leis }\end{array}$ & $\begin{array}{c}\text { Frequência } \\
\text { de Vetos } \\
\text { (dias) }\end{array}$ \\
\hline Eurico Dutra & 1.833 & 1.362 & 30 & 13 & $43,33 \%$ & $2,20 \%$ & 61,10 \\
\hline Getúlio Vargas & 1.402 & 1.024 & 53 & 31 & $58,49 \%$ & $5,18 \%$ & 26,45 \\
\hline João Café Filho & 341 & 336 & 49 & 18 & $36,73 \%$ & $14,58 \%$ & 6,96 \\
\hline Jucelino Kubitchek & 1.833 & 1.174 & 119 & 78 & $65,55 \%$ & $10,14 \%$ & 15,40 \\
\hline Jânio Quadros & 206 & 61 & 19 & 9 & $47,37 \%$ & $31,15 \%$ & 10,84 \\
\hline João Goulart & 935 & 378 & 53 & 42 & $79,25 \%$ & $14,02 \%$ & 17,64 \\
\hline José Sarney & 1.826 & 358 & 75 & 39 & $52,00 \%$ & $21,01 \%$ & 24,35 \\
\hline $\begin{array}{l}\text { Fernando Collor de } \\
\text { Mello }\end{array}$ & 932 & 479 & 152 & 84 & $55,26 \%$ & $31,73 \%$ & 6,13 \\
\hline Itamar Franco & 821 & 523 & 100 & 58 & $58,00 \%$ & $19,12 \%$ & 8,21 \\
\hline $\begin{array}{l}\text { Fernando Henrique } \\
\text { Cardoso }\end{array}$ & 2.922 & 1.731 & 299 & 196 & $65,55 \%$ & $17,27 \%$ & 9,77 \\
\hline $\begin{array}{l}\text { Luís Inácio Lula da } \\
\text { Silva }\end{array}$ & 2.922 & 1.785 & 357 & 196 & $54,90 \%$ & $20,00 \%$ & 8,18 \\
\hline Dilma Roussef & 1.096 & 720 & 178 & 136 & $76,40 \%$ & $24,72 \%$ & 6,16 \\
\hline \multicolumn{1}{|c|}{ TOTAIS } & 24.573 & 12.626 & 1.645 & 1.005 & - & - & - \\
\hline
\end{tabular}

Fonte dos dados brutos: Sistemas de Informação do Senado Federal e da Câmara dos Deputados, Diário do Senado Federal e do Congresso Nacional; Relatório Anual da Presidência do Senado Federal.

Nota: José Sarney foi o primeiro presidente no segundo período democrático.

A chamada magnitude de vetos (GROHMANN, 2003), que é a quantidade de vetos em relação à produção legal total, confirmou as previsões de Grohmann, mantendo-se maior no regime da Constituição de 1988 (BRASIL, 1988). Também apresentam elevação os percentuais 
no emprego de vetos parciais e a frequência do veto, em dias. No entanto, as diferenças não são tão dramáticas, como a leitura do quadro anterior permite ver.

A diferença mais interessante refere-se ao tempo de mandato em dias. O período anterior registrou para os titulares da Presidência um mandato médio de cerca de 1.091 dias, enquanto depois do regime autoritário, essa média sobe para 1.753 (até 2014, quando houve mais uma reeleição, da Presidente Dilma Rousseff). Mencione-se, ainda, a intensificação do veto na $54^{\mathrm{a}}$ Legislatura (Dilma Rousseff), sendo de 1 veto para cada 6 dias, número somente verificado sob Collor.

A ação de governar pelas leis intensificou-se (de 722 leis médias por Presidente para 932 leis médias). A ação de vetar cresceu também (de 54 vetos médios para 194), mas cresceu em uma proporção maior, como se pode notar. Ainda assim, Grohmann (2003) demonstrou que a quantidade de leis produzidas não produz efeito considerável sobre a emissão total de vetos.

Deve-se fazer uma ressalva importante, no entanto, quanto às leis orçamentárias. No período constitucional pós 1988 a quantidade de leis orçamentárias atingiu um patamar considerável. Autores como Moya (2005) e Figueiredo e Limongi (1999) chegam a excluir tais projetos de suas análises empíricas em razão da dimensão quantitativa. Desconsideradas as leis orçamentárias do cômputo da produção legal nacional, tem-se uma elevação, mas, se mantidas no quadro, indicam o contrário, uma leve tendência à redução. A Figura 15 permite concluir que a redução na quantidade de leis orçamentárias segue uma tendência contrária à das demais. 
Figura 15: Gráfico da Produção Anual de Leis 1988-2014

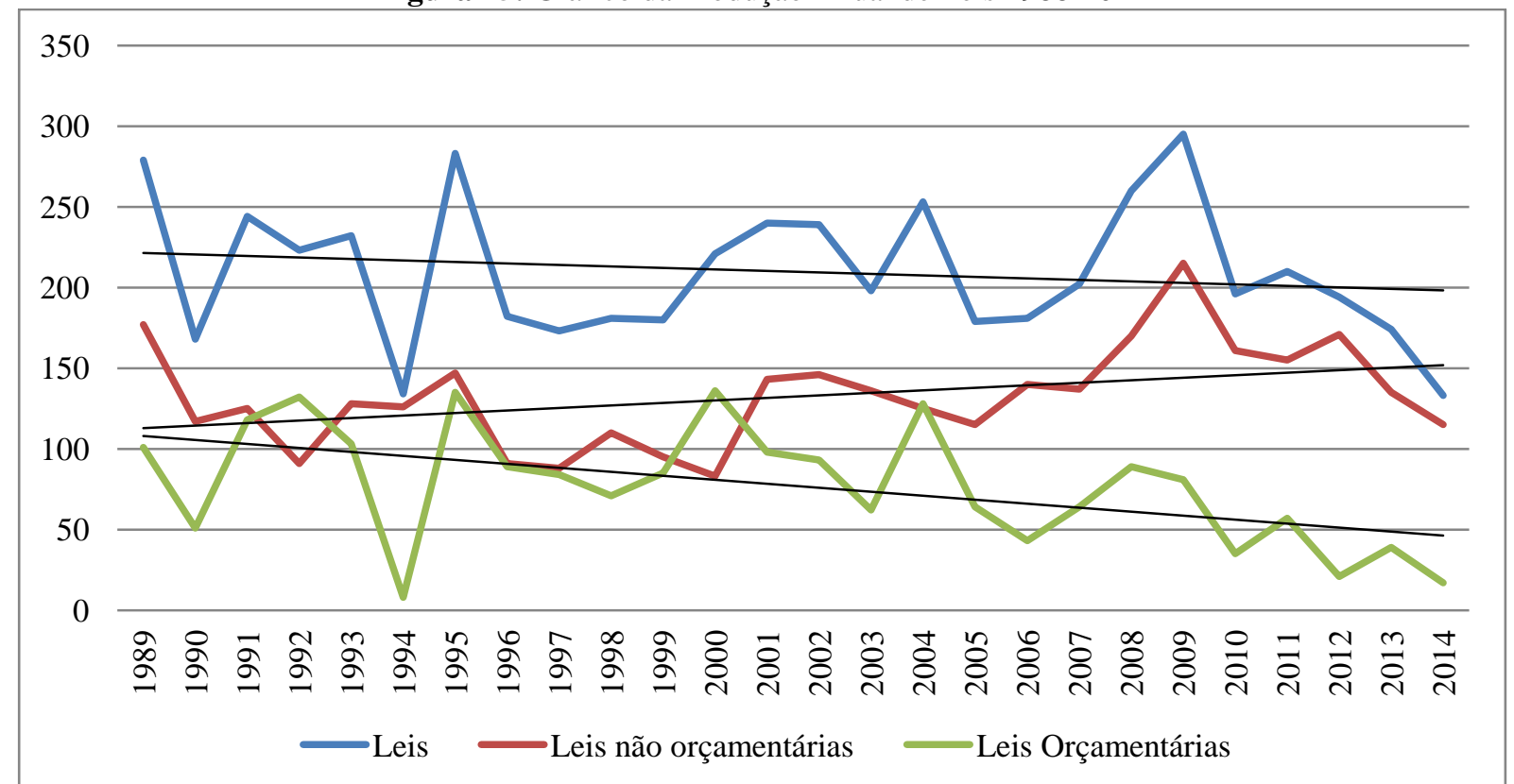

Fonte dos dados brutos: Sistemas de Informação do Senado Federal e da Câmara dos Deputados, Diário do Senado Federal e do Congresso Nacional; Relatório Anual da Presidência do Senado Federal.

Esses números indicam o processo evolutivo do sistema de governo presidencialista com o instituto do veto, que se caracteriza por presidentes longevos, produção legislativa crescente, com tendência à redução das leis orçamentarias, e mais vetos emitidos, predominantemente parciais.

Apresenta-se a seguir o inventário das sessões realizadas e dos vetos apostos no recorte de 1988 a 2014.

\section{Sessões conjuntas:}

O universo dos dados abrange todas as sessões conjuntas do Congresso Nacional em que tenham sido pautados vetos, efetivamente realizadas, ainda que não tenha havido votações, desde novembro de 1988.

As sessões conjuntas são aquelas definidas no $\S 3^{\circ}$ do art. 57 da Constituição Federal (BRASIL, 1988), litteris: 
“§ $3^{\circ}$ Além de outros casos previstos nesta Constituição, a Câmara dos Deputados e o Senado Federal reunir-se-ão em sessão conjunta para:

I - inaugurar a sessão legislativa;

II - elaborar o regimento comum e regular a criação de serviços comuns às duas Casas;

III - receber o compromisso do Presidente e do Vice-Presidente da República;

IV - conhecer do veto e sobre ele deliberar.” (negrito nosso)

Além da apreciação de vetos presidenciais, outra competência do plenário das sessões conjuntas é apreciar matérias orçamentárias: leis do plano plurianual, das diretrizes orçamentárias, do orçamento anual e os créditos suplementares e especiais (os créditos extraordinários, veiculados por medidas provisórias, competência dos plenários de cada Casa, não se incluem nesse rol).

Totalizaram-se, de novembro de 1988 a dezembro de 2014, ou seja, da 48a (três últimos anos) à 54a Legislatura, 263 sessões de veto, de um total de 738 sessões conjuntas convocadas. Mas apenas cerca de um terço dessas 263 sessões foi efetivo, ou seja, de sessões em que se pautaram vetos, somente em 86 (33\%), houve resolução de vetos. Isso parece ter ocorrido em razão da falta de quórum (em 151 de 263 sessões, 57\%) ou outros motivos (em 26 sessões), impedindo que houvesse atuação sobre eles. Ressalte-se que o número de sessões convocadas e canceladas antes de seu início não pode ser mensurado, por falta de documentação comprobatória dessa informação para datas anteriores a 2011.

Um exemplo desse tipo de ocorrência é a sessão convocada para 11 de maio de 2011, cancelada pelo Presidente do Senado, em atendimento à solicitação feita pela maioria absoluta dos líderes das duas Casas (BRASIL, 11/05/2011a, p. 15080). Na semana da sessão convocada para tratar de 125 vetos presidenciais (BRASIL, 10/5/2011b), iniciava-se a XIV Marcha dos Prefeitos, e os líderes decidiram evitar eventuais pressões advindas dos prefeitos. Mas, esse é o único registro em diário de manifestação de Líderes sobre sessões conjuntas.

Após a promulgação da Constituição Federal, em 5 de outubro de 1988 (BRASIL, 1988), de acordo com o inciso I do $\S 1^{\circ}$ do art. 25 do Ato das Disposições Constitucionais Transitórias ADCT, as matérias constantes da Ordem do Dia deveriam ter sido apreciadas no prazo de cento e oitenta dias, a contar do dia 5 de outubro de 1988, prazo esse encerrado em 5 de junho de 1989.

Na primeira sessão conjunta após a promulgação, ocorrida em 6 de outubro de 1988, havia na pauta da sessão conjunta do Congresso Nacional 67 (sessenta e sete) itens, todos eles Decretos-Leis (medidas provisórias da época). Esse que viria a ser um dos poderes presidenciais 
mais criticados da Constituição que se promulgara, já causava danos à pauta da sessão conjunta um dia depois de sua promulgação.

A primeira sessão para apreciação de vetos presidenciais foi convocada para o dia 9 de novembro de 1988, com um veto total na pauta, com prazo constitucional esgotado, portanto, já nos termos do $\S 6^{\circ}$ do art. 66 da Constituição de 1988 (BRASIL, 1988). Na ocasião, verificada a falta de quórum, o Presidente convocou outra sessão para o dia 16 seguinte, com medidas provisórias na pauta, e o veto total. Sustenta-se, ainda, a percepção inicial de que a pauta predominante eram as medidas provisórias e os vetos presidenciais. Essa sessão (de 16/11/1988) sequer foi aberta, também por falta de quórum.

Nota-se, desde o primeiro momento, a dificuldade da sessão conjunta em garantir quórum (Figura 16). As duas primeiras legislaturas (de 1988 a 1994) experimentaram uma média de cerca de $71 \%$ de sessões que não puderam ocorrer por falta de quórum. Essa dificuldade foi frequente até 1992, quando as sessões de veto, já raras, passaram a ocorrer cada vez mais raramente, atingindo uma média inferior a duas sessões por ano.

Figura 16: Gráfico das Dificuldades de Quórum na $48^{\mathrm{a}}$ e $49^{\mathrm{a}}$ Legislaturas

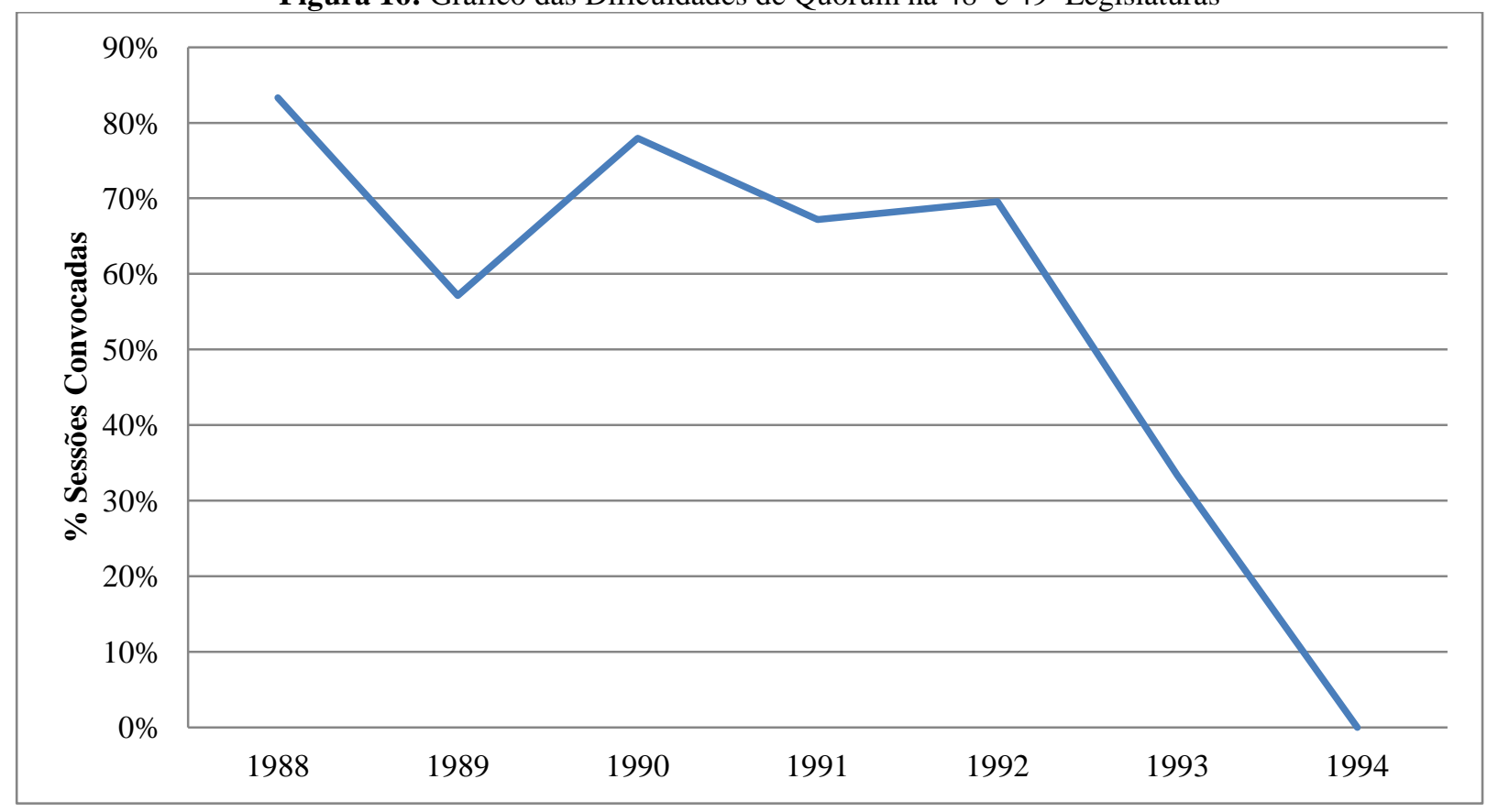

Fonte dos dados brutos: Sistemas de Informação do Senado Federal e da Câmara dos Deputados, Diário do Senado Federal e do Congresso Nacional; Relatório Anual da Presidência do Senado Federal.

Nota: expressa-se o percentual de sessões que foram iniciadas mas não foram efetivas por falta de número para deliberar sobre vetos, que requerem maioria absoluta para rejeição ou maioria absoluta presente, no mínimo, para sua manutenção. 
O padrão de falta de quórum parece ter sido substituído pelo da redução da convocação das sessões de veto, com o uso de cédula de votação. Desde sua implantação, em 1992, a média de sessões com falta de quórum caiu de $71 \%$ para $8 \%$, ao passo que a média de sessões efetivamente realizadas para resolver sobre vetos caiu de cerca de 11 sessões para menos de 2 sessões anuais.

Uma explicação para esse comportamento é encontrada em Grohmann (2003), quando o autor descreve a importância da mudança do quórum para rejeição de vetos, de dois terços dos presentes (1946-1964) para maioria absoluta da composição das Casas (1988). O autor reconhece uma dupla dificuldade no novo quórum: é difícil para as "maiorias derrubadoras" obter número para rejeitar o veto, mas não menos complicada é a obtenção do número de parlamentares para mantê-lo (“maiorias mantenedoras”). Isso ajuda a explicar porque as sessões tornaram-se raras depois de um período em que o quórum era problema em muitas convocações sucessivas.

As sessões ocorreram sob as presidências de oito presidentes do Congresso Nacional, conforme Quadro 8 abaixo:

Quadro 8: Presidentes do Congresso - Sessões Efetivas

\begin{tabular}{|c|c|c|c|}
\hline Mesa & Presidente & Partido & Sessões Efetivas \\
\hline $1987-1988$ & Humberto Lucena & PMDB & 1 \\
\hline $1989-1990$ & Nelson Carneiro & PMDB & 30 \\
\hline $1991-1992$ & Mauro Benevides & PMDB & 23 \\
\hline $1993-1994$ & Humberto Lucena & PMDB & 3 \\
\hline $1995-1996$ & José Sarney & PMDB & 6 \\
\hline $1997-1998$ & Antônio Carlos Magalhães & PFL & 1 \\
\hline $1999-2000$ & Antônio Carlos Magalhães & PFL & 5 \\
\hline $2001-2002$ & Ramez Tebet & PMDB & 0 \\
\hline $2003-2004$ & José Sarney & PMDB & 1 \\
\hline $2005-2006$ & Renan Calheiros & PMDB & 2 \\
\hline $2007-2008$ & Renan Calheiros/Garibaldi Alves Filho & PMDB & $0 / 2$ \\
\hline $2009-2010$ & José Sarney & PMDB & 3 \\
\hline $2011-2012$ & José Sarney & PMDB & 0 \\
\hline $2013-2014$ & Renan Calheiros & PMDB & 9 \\
\hline
\end{tabular}

Fonte dos dados brutos: Sistemas de Informação do Senado Federal e da Câmara dos Deputados, Diário do Senado Federal e do Congresso Nacional; Relatório Anual da Presidência do Senado Federal.

Nota: mandatos com duração de 2 anos. 
Destacam-se os quatro mandatos de José Sarney na Presidência do Congresso. A tendência decrescente de sessões efetivas é modificada apenas na Mesa 2013-2014 de Renan Calheiros. O único presidente a não realizar nenhuma sessão para apreciar vetos foi Ramez Tebet, sob cuja presidência houve tão somente declaração de prejudicialidade de vetos.

O conjunto de tabelas e quadros a seguir oferece um panorama das principais características dos vetos do período estudado. 


\section{Vetos:}

A primeira mensagem de veto presidencial lida após a CF88 foi a n 136, de 1988 (veto total), em 19 de outubro de 1988, juntamente com as de $\mathrm{n}^{\text {os }} 141$ e 142, de 1988 . A primeira mensagem de veto a ser apreciada foi a de $\mathrm{n}^{\circ}$ 130, de 1988 (veto total), que fora lida em 14/9/1988. Essas quatro mensagens tiveram seu envio fundamentado na Constituição anterior. A primeira mensagem de veto cujo envio fundamenta-se na CF88 é a nº 153, de 1988 (veto parcial). Por essa razão, o prazo constitucional das quatro primeiras foi de 45 dias e da quinta em diante, de 30 dias.

O universo amostral abrange todos os vetos apostos pelos presidentes da República, submetidos, em sua apreciação, às regras de tramitação da Constituição de 1988 (BRASIL, 1988). Totalizaram-se 1.160 vetos, entre totais e parciais, assim descritos:

\subsection{Vetos por tipo}

Verifica-se a larga predominância de parciais, 778 para 382 vetos totais.

Figura 17: Gráfico de Vetos, classificados por tipo.

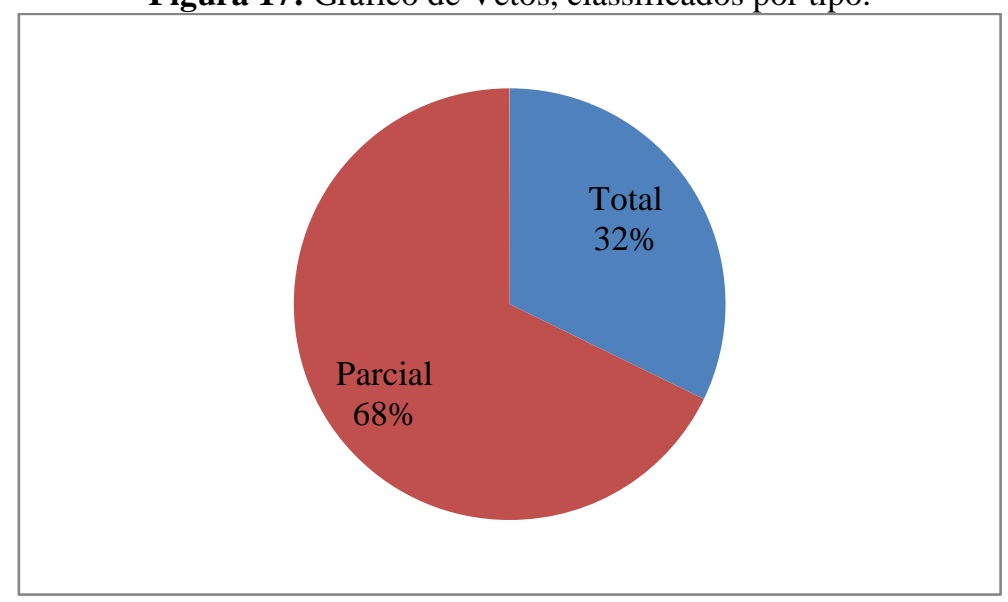

Fonte dos dados brutos: Sistemas de Informação do Senado Federal e da Câmara dos Deputados, Diário do Senado Federal e do Congresso Nacional; Relatório Anual da Presidência do Senado Federal. 


\subsection{Vetos por modalidade de votação}

Figura 18: Gráfico de Vetos, por modalidade de votação

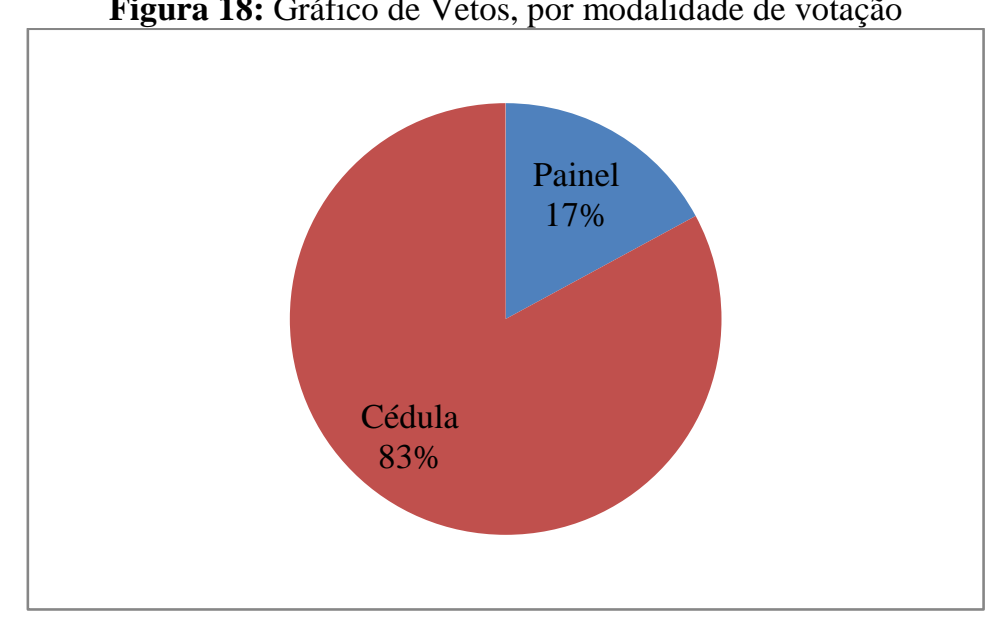

Fonte dos dados brutos: Sistemas de Informação do Senado Federal e da Câmara dos Deputados, Diário do Senado Federal e do Congresso Nacional; Relatório Anual da Presidência do Senado Federal.

Conforme o discutido no Capítulo 4, embora a cédula de votações tenha sido utilizada em menos sessões (46 sessões de vetos) que o painel (217 sessões de vetos), em razão dos motivos já analisados, a cédula termina por responder por um total muito superior de tudo o que o Congresso já decidiu sobre vetos.

\subsection{Vetos por relatório}

O texto original do Regimento Comum (BRASIL, 1970) previa a formação de uma comissão mista de deputados e senadores, incumbida de emitir um relatório, meramente indicativo (não vinculava o plenário), contando para tanto com o prazo de 20 dias. A formação do colegiado foi se tornando cada vez mais rara, provavelmente em razão do valor do relatório no processo decisório. A última comissão se formou em 1996. No total, apenas 40 dos vetos tiveram relatório da comissão mista (cerca de 3,4\%). 


\subsection{Vetos por presidente autor}

Tabela 8: Vetos Presidenciais no Brasil: 1988-2014 - Presidente autor

\begin{tabular}{|c|c|c|c|c|c|c|}
\hline \multirow[t]{2}{*}{ ANO } & \multirow[t]{2}{*}{ PRESIDENTE } & \multicolumn{2}{|c|}{ VETOS TOTAIS } & \multicolumn{2}{|c|}{$\begin{array}{c}\text { VETOS } \\
\text { PARCIAIS }\end{array}$} & \multirow[t]{2}{*}{$\begin{array}{c}\text { TOTAL } \\
\text { DE } \\
\text { VETOS }\end{array}$} \\
\hline & & Abs & $\%$ & Abs & $\%$ & \\
\hline 1988 & Sarney & 3 & $60,0 \%$ & 2 & $40,0 \%$ & 5 \\
\hline 1989 & Sarney & 32 & $52,5 \%$ & 29 & $47,5 \%$ & 61 \\
\hline 1990 & Sarney & 1 & $11,1 \%$ & 8 & $88,9 \%$ & 9 \\
\hline 1990 & Collor & 24 & $55,8 \%$ & 19 & $44,2 \%$ & 43 \\
\hline 1991 & Collor & 27 & $48,2 \%$ & 29 & $51,8 \%$ & 56 \\
\hline 1992 & Collor & 17 & $32,7 \%$ & 35 & $67,3 \%$ & 52 \\
\hline 1992 & Franco & 0 & $0,0 \%$ & 1 & $100,0 \%$ & 1 \\
\hline 1993 & Franco & 24 & $40,0 \%$ & 36 & $60,0 \%$ & 60 \\
\hline 1994 & Franco & 18 & $48,6 \%$ & 19 & $51,4 \%$ & 37 \\
\hline 1995 & Franco & 0 & $0,0 \%$ & 2 & $100,0 \%$ & 2 \\
\hline 1995 & FHC & 36 & $61,0 \%$ & 23 & $39,0 \%$ & 59 \\
\hline 1996 & FHC & 17 & $47,2 \%$ & 19 & $52,8 \%$ & 36 \\
\hline 1997 & FHC & 5 & $18,5 \%$ & 22 & $81,5 \%$ & 27 \\
\hline 1998 & FHC & 5 & $18,5 \%$ & 22 & $81,5 \%$ & 27 \\
\hline 1999 & FHC & 4 & $25,0 \%$ & 12 & $75,0 \%$ & 16 \\
\hline 2000 & FHC & 8 & $18,2 \%$ & 36 & $81,8 \%$ & 44 \\
\hline 2001 & FHC & 15 & $28,8 \%$ & 37 & $71,2 \%$ & 52 \\
\hline 2002 & FHC & 13 & $34,2 \%$ & 25 & $65,8 \%$ & 38 \\
\hline 2003 & Lula & 12 & $27,3 \%$ & 32 & $72,7 \%$ & 44 \\
\hline 2004 & Lula & 5 & $14,3 \%$ & 30 & $85,7 \%$ & 35 \\
\hline 2005 & Lula & 9 & $24,3 \%$ & 28 & $75,7 \%$ & 37 \\
\hline 2006 & Lula & 9 & $26,5 \%$ & 25 & $73,5 \%$ & 34 \\
\hline 2007 & Lula & 8 & $19,5 \%$ & 33 & $80,5 \%$ & 41 \\
\hline 2008 & Lula & 15 & $27,8 \%$ & 39 & $72,2 \%$ & 54 \\
\hline 2009 & Lula & 19 & $27,5 \%$ & 50 & $72,5 \%$ & 69 \\
\hline 2010 & Lula & 14 & $32,6 \%$ & 29 & $67,4 \%$ & 43 \\
\hline 2011 & Dilma Rousseff & 9 & $24,3 \%$ & 28 & $75,7 \%$ & 37 \\
\hline 2012 & Dilma Rousseff & 9 & $17,0 \%$ & 44 & $83,0 \%$ & 53 \\
\hline 2013 & Dilma Rousseff & 17 & $29,8 \%$ & 40 & $70,2 \%$ & 57 \\
\hline 2014 & Dilma Rousseff & 7 & $22,6 \%$ & 24 & $77,4 \%$ & 31 \\
\hline
\end{tabular}

Fonte: Sistemas de Informação do Senado Federal e da Câmara dos Deputados, Diário do Senado Federal e do Congresso Nacional, Relatório Anual da Presidência do Senado Federal. 
Reafirma-se que, a partir do governo Fernando Henrique Cardoso, a predominância de vetos parciais, que se tornou o veto preferencial, em média duas vezes mais praticado que o veto total. Nota-se uma média anual de vetos maior em Collor (54). FHC praticou a menor quantidade média de vetos (38), e Lula e Dilma apresentam a mesma média (45). A partir de FHC a prática de vetos totais não muda mais de patamar, sendo a elevação verificada para Lula e Dilma, quase totalmente atribuível aos parciais, o que reforça a noção de que o veto parcial passou a ser o veto por definição. Confirma-se, ainda, a previsão de Moya (2005) para menos vetos totais ao final da legislatura.

\subsection{Vetos por autor da matéria vetada:}

Tabela 9 Vetos Presidenciais no Brasil: 1988-2014 - Autor vetado

\begin{tabular}{l|c|c|r|c|c}
\hline \multicolumn{1}{c|}{ Autor } & Valor & $\begin{array}{c}\text { Veto } \\
\text { Total }\end{array}$ & \multicolumn{1}{c|}{ \% } & $\begin{array}{c}\text { Veto } \\
\text { Parcial }\end{array}$ & \% \\
\hline Senado & 200 & 106 & $53 \%$ & 94 & $47 \%$ \\
\hline Câmara & 535 & 226 & $42 \%$ & 309 & $58 \%$ \\
\hline Congresso & 85 & 5 & $6 \%$ & 80 & $94 \%$ \\
\hline Executivo & 274 & 20 & $7 \%$ & 254 & $93 \%$ \\
\hline Judiciário & 44 & 20 & $45 \%$ & 24 & $55 \%$ \\
\hline Outros & 22 & 5 & $23 \%$ & 17 & $77 \%$ \\
\hline
\end{tabular}

Fonte: Sistemas de Informação do Senado Federal e da Câmara dos Deputados, Diário do Senado Federal e do Congresso Nacional, Relatório Anual da Presidência do Senado Federal.

Reafirmada a tendência já percebida por Grohmann (2003), Lamounier (2005) e Moya (2005), de mais vetos parciais em matérias de autoria do Executivo. Destaca-se, no entanto, a maior incidência de vetos totais em matérias de origem no Senado, sendo o único autor a sofrer mais vetos totais que parciais. Chama a atenção também o reduzido quantitativo de vetos totais em matérias de origem no Congresso.

As matérias de autoria do Congresso são os projetos de lei de conversão apresentados perante o plenário do Congresso ou por Comissão Mista, ou seja, derivam das medidas provisórias, de autoria do Executivo, anteriores à Emenda Constitucional $\mathrm{n}^{0}$ 32, de 2001. A categoria “Outros” compreende o Tribunal de Contas da União e o Ministério Público da União. 


\subsection{Vetos pelo tema da matéria vetada}

Tabela 10: Vetos Presidenciais no Brasil: 1988-2014 - Tema da matéria vetada

\begin{tabular}{l|c|c}
\hline \multicolumn{2}{c|}{ Tema da Matéria Vetada } & \% \\
\hline Administrativo & 270 & $23 \%$ \\
\hline Econômico & 380 & $33 \%$ \\
\hline Honorífico & 35 & $3 \%$ \\
\hline Jurídico & 129 & $11 \%$ \\
\hline Social & 346 & $30 \%$ \\
\hline
\end{tabular}

Fonte dos dados brutos: Sistemas de Informação do Senado Federal e da Câmara dos Deputados, Diário do Senado Federal e do Congresso Nacional; Relatório Anual da Presidência do Senado Federal.

A Tabela 10 atesta a predominância dos temas econômico e social. Quando se inclui a autoria na análise, percebe-se uma agenda substantiva tencionada por esses dois vetores: as exigências coletivas sociais e as exigências da economia. A tendência já identificada por Grohmann (2003) confirma-se na série temporal estudada: há mais vetos totais aplicados a matérias de temática social seguida pelas áreas econômica e administrativa; e há mais vetos parciais na área econômica, seguida pela área social.

O autor identifica também que a agenda econômica vetada tem origem predominante no Executivo, enquanto a agenda social tem origem no Legislativo. Ressalvam-se somente os casos dos vetos parciais de matérias originárias do Legislativo, em que a distribuição é muito parecida entre ambas as áreas, social e econômica (Figuras 19 e 20). 
Figura 19: Gráficos dos Temas da Matéria Vetada - Autoria do Executivo 1988-2014 (médias anuais)

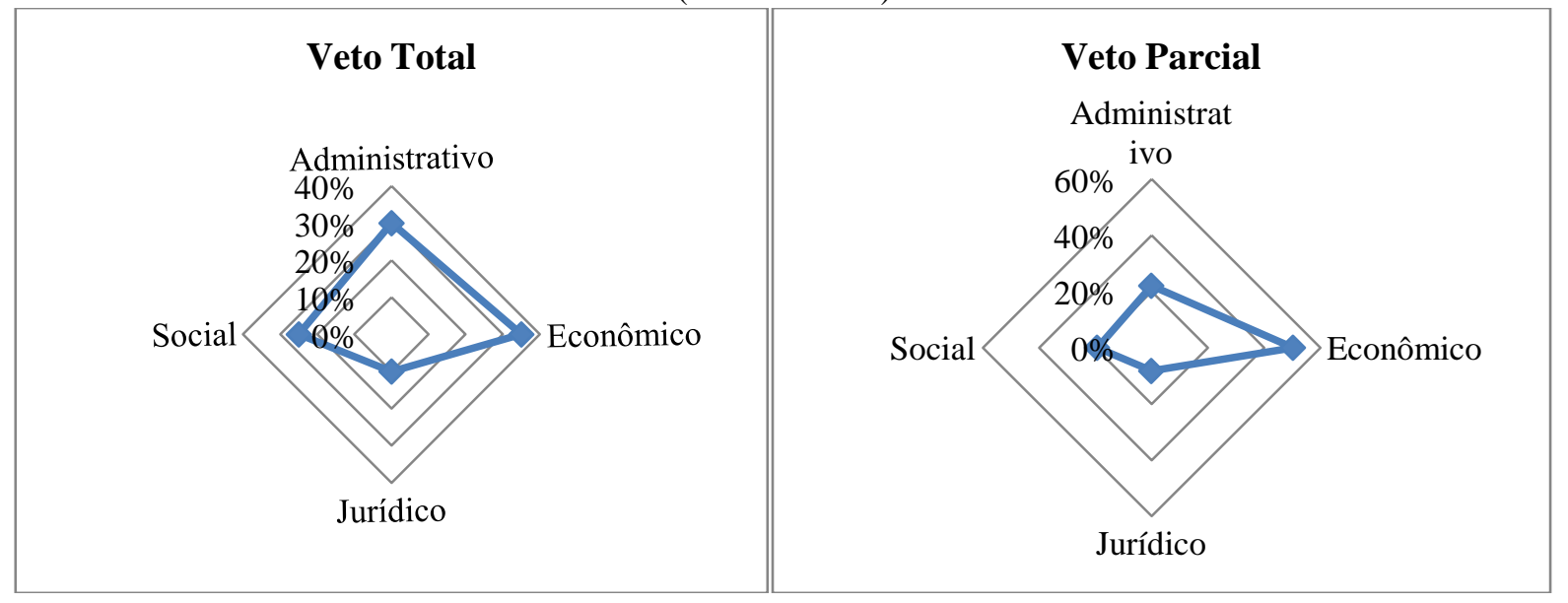

Fonte dos dados brutos: Sistemas de Informação do Senado Federal e da Câmara dos Deputados, Diário do Senado Federal e do Congresso Nacional; Relatório Anual da Presidência do Senado Federal.

Nota: foram excluídos os vetos sobre projetos com temas honoríficos, por serem em número muito reduzido.

Figura 20: Gráficos dos Temas da Matéria Vetada - Autoria do Legislativo - 1988-2014 (médias anuais)

Veto Total
Administrat
Social Econômico

Fonte dos dados brutos: Sistemas de Informação do Senado Federal e da Câmara dos Deputados, Diário do Senado Federal e do Congresso Nacional; Relatório Anual da Presidência do Senado Federal.

Nota: foram excluídos os vetos sobre projetos com temas honoríficos, por serem em número muito reduzido.

Essas informações confirmam a conclusão de Figueiredo e Limongi (1999), atestada por Moya (2005), de que haveria uma agenda de ordem econômica e administrativa praticada pelo Executivo e outra de ordem social praticada pelo Legislativo. Moya mensura, no período de 1988 a 2000 , um percentual de $60 \%$ e $75 \%$ de projetos aprovados, tratando, respectivamente, de temas 
administrativos e econômicos, e de autoria do Presidente da República. Já 58\% dos projetos aprovados sobre temas sociais tinham o Legislativo como autor.

Os gráficos acima sinalizam a confirmação dessa agenda econômico-administrativa do Executivo, defendida com veto, nos casos de alterações do Legislativo. Quando o este é o autor, os vetos totais espelham sua agenda social, mas a incidência temática do veto parcial traz outra informação, que é a igual resistência do Presidente à agenda econômica do Congresso.

Dado que é razoável supor que os vetos a matérias de autoria do Executivo são oriundos de alterações do Legislativo a suas iniciativas, e dada a menor incidência de vetos sobre a agenda social, percebe-se uma maior tolerância do Presidente à agenda social do Legislativo em matérias de iniciativa do Executivo. Já a iniciativa do Legislativo na agenda social sofre mais vetos, em uma proporção tão grande quanto a verificada para a agenda econômica.

O entendimento dessa “agenda impedida” permite visualizar as áreas de conflito entre os poderes, no que tange a autoria, ou a iniciativa da legislação. O que se pode concluir de pronto é que o Presidente da República defende seu poder de iniciativa em todos os temas, com especial ênfase nas matérias de ordem econômica. O pequeno espaço deixado para o Legislativo encontrase concentrado na área temática social, desde que de autoria do Executivo, e reside nas emendas aprovadas e sancionadas.

O tema econômico abrange uma grande quantidade de assuntos, tais como viação e transportes, agricultura, pecuária e abastecimento, trânsito, planejamento e orçamento, desenvolvimento regional, política fundiária e reforma agrária, minas e energia, entre outros. As matérias orçamentárias, que inflam os números de aprovação, como esclarece Moya (2005), não o fazem quanto aos vetos, onde a incidência sobre matérias orçamentárias é pequena (cerca de $6 \%)$.

Essa titularidade sobre matéria orçamentária também reforça a agenda econômica do Executivo, já que sinaliza a forte potência iniciadora do Presidente em matérias relativas a finanças públicas. São raras as modificações substanciais promovidas pelo Legislativo aos projetos de lei de cunho orçamentário, todos apreciados em sessões conjuntas, o que sinaliza a proximidade entre essas duas valências do Presidente da República: estabelecedor de agenda e ator de veto institucional. Trata-se da potência administrativa do Presidente da República, 
garantida pelo texto constitucional, ao reservar-lhe com exclusividade a iniciativa das leis orçamentarias.

A variável explicativa "tema” surge como uma das mais interessantes na descrição e compreensão do veto. Somem-se as variáveis de importância identificadas por Moya (2005): a urgência na tramitação e o processamento nominal de votação, e ter-se-ia um importante conjunto de variáveis para o estudo do veto. Isso porque essas variáveis tocam o cerne da formação legislativa das políticas públicas - a agenda substantiva de políticas do Poder Executivo.

\subsection{Vetos pelo resultado de apreciação:}

Tabela 11: Vetos Presidenciais no Brasil: 1988-2014 - Resultado da Apreciação

\begin{tabular}{l|r|r}
\hline RESULTADO & ABSOLUTO & \multicolumn{1}{c}{$\%$} \\
\hline Mantido & 862 & $73 \%$ \\
\hline Rejeitado & 27 & $2 \%$ \\
\hline Prejudicado & 67 & $6 \%$ \\
\hline Tramitando & 229 & $19 \%$ \\
\hline Totais & $\mathbf{1 1 8 5}$ & $\mathbf{1 0 0 \%}$
\end{tabular}

Fonte: Sistemas de Informação do Senado Federal e da Câmara dos Deputados, Diário do Senado Federal e do Congresso Nacional, Relatório Anual da Presidência do Senado Federal.

Nota: o total de vetos apreciados é superior ao total de vetos apostos pelo fato de haver vetos deliberados em mais de uma votação, inclusive com resultados diferentes.

Como já descrito para as sessões, a quantidade de vetos rejeitados é reduzida, sendo inclusive menor que a quantidade de vetos prejudicados. A quantidade de vetos ainda em tramitação para o período estudado é de quase $20 \%$, atestando a não decisão para o universo amostral. 


\subsection{Vetos pelo tempo de tramitação:}

Tabela 12: Vetos Presidenciais no Brasil: 1988-2014 - Tempo de Tramitação

\begin{tabular}{l|c|c}
\multicolumn{1}{c|}{ Tempo } & Quantidade & $\mathbf{\%}$ \\
\hline até 30 dias & 30 & $3 \%$ \\
\hline entre 31 e 365 & 345 & $36 \%$ \\
\hline entre 366 e 730 & 122 & $13 \%$ \\
\hline Entre 731 e 1095 & 77 & $8 \%$ \\
\hline Entre 1096 e 1460 & 56 & $6 \%$ \\
\hline Mais de 1460 & 326 & $34 \%$
\end{tabular}

Fonte: Sistemas de Informação do Senado Federal e da Câmara dos Deputados, Diário do Senado Federal e do Congresso Nacional, Relatório Anual da Presidência do Senado Federal.

Quase metade dos vetos foi apreciada depois de mais de dois anos de tramitação, e a quantidade de vetos apreciados no prazo constitucional é ínfima. Isso atesta não só a não apreciação de vetos, como também a tramitação anômala.

\subsection{Vetos rejeitados}

Em 26 anos da nova fase constitucional, dos 865 vetos resolvidos, apenas 27 foram rejeitados. Descrevem-se a seguir esses vetos, com ênfase nas variáveis tema e tempo. Mais da metade, 15 vetos (56\%) deles tratavam de temas administrativos. Todos eles tratavam de interesses de grupo. Quer fossem alterações remuneratórias, quer fosse a criação ou manutenção de gratificações e vantagens, todos os vetos contrariavam interesses de ordem econômica de categorias da burocracia estatal. O Quadro 9 a seguir resume os casos.

Quadro 9: Vetos Rejeitados - Tema Administrativo - Assuntos

\begin{tabular}{|c|l|}
\hline $\mathbf{N}^{\mathbf{0}}$ & \multicolumn{1}{|c|}{ Assunto da Matéria Vetada } \\
\hline $18 / 1989$ & $\begin{array}{l}\text { Transforma cargos de chefia de zonas eleitorais em cargos de direção dos Tribunais } \\
\text { Regionais Eleitorais. }\end{array}$ \\
\hline $28 / 1989$ & Instituição de gratificação a servidores do Supremo Tribunal Federal. \\
\hline $29 / 1989$ & Instituição de gratificação a servidores do Superior Tribunal de Justiça. \\
\hline $30 / 1989$ & Instituição de gratificação a servidores da Justiça Federal. \\
\hline
\end{tabular}




\begin{tabular}{|c|l|}
\hline $31 / 1989$ & Instituição de gratificação a servidores da Justiça do Trabalho. \\
\hline $32 / 1989$ & Instituição de gratificação a servidores da Justiça Eleitoral. \\
\hline $33 / 1989$ & Instituição de gratificação a servidores da Justiça Militar. \\
\hline $34 / 1989$ & Instituição de gratificação a servidores do Ministério Público da União. \\
\hline $163 / 1989$ & Instituição de gratificação a servidores do Tribunal de Contas da União. \\
\hline $258 / 1990$ & $\begin{array}{l}\text { Regime Jurídico do Servidor: conversão de licença prêmio em pecúnia; acréscimos nos } \\
\text { padrões para aposentadoria; acréscimo aos proventos de funções exercidas nadidade; } \\
\text { outras vantagens. }\end{array}$ \\
\hline $15 / 1991$ & Complementação de aposentadoria de ferroviários. \\
\hline $95 / 1992$ & $\begin{array}{l}\text { Complementação da aposentadoria do pessoal do extinto Departamento de Correios e } \\
\text { Telégrafos - DCT. }\end{array}$ \\
\hline $51 / 1994$ & $\begin{array}{l}\text { Tetos Remuneratórios: abertura para previsões legais de exclusão do conceito de } \\
\text { remuneração (indenizações “fura-teto”); criação de vantagem pessoal para absorver casos de } \\
\text { “fura-teto” anteriores à lei. }\end{array}$ \\
\hline $13 / 2005$ & Plano de carreira dos servidores do Senado Federal. \\
\hline $14 / 2005$ & Plano de carreira dos servidores da Câmara dos Deputados. \\
\hline
\end{tabular}

Fonte dos dados brutos: Sistemas de Informação do Senado Federal e da Câmara dos Deputados, Diário do Senado Federal e do Congresso Nacional; Relatório Anual da Presidência do Senado Federal.

Nota: emprega-se assunto como desdobramento do tema da matéria vetada.

Note-se que apenas dois deles encontram-se fora das duas primeiras legislaturas pós Constituição de 1988 (BRASIL, 1988), o que permite a conclusão de que se tratava, entre outras questões, de ajustes nos interesses econômicos corporativos da burocracia em face do novo regime constitucional. Não seria razoável supor que os interesses corporativos deixaram de marcar pautas depois de 1994. Prova disso são os vetos das carreiras do Legislativo federal, rejeitados em 2005. Mas, o fato é que os eventuais conflitos sobre esse tema provavelmente passaram a ser resolvidos sem que a solução dependesse do processo decisório do veto.

Outros 30\% (oito vetos) tratavam de matéria econômica, sendo que duas delas tratavam de política geral de salários e do salário mínimo. As demais tratavam de benefícios econômicos e isenções a diversos grupos, tais como isenções fiscais e econômicas, bem como partilha de exploração de petróleo extraído da camada de pré-sal (conhecido como "veto dos royalties"). O Quadro 10 sumariza os temas: 
Quadro 10: Vetos Rejeitados - Tema Econômico - Assuntos

\begin{tabular}{|c|l|}
\hline \multicolumn{1}{|c|}{$\mathbf{N}^{\mathbf{0}}$} & \multicolumn{1}{|c|}{ Assunto da Matéria Vetada } \\
\hline $22 / 1989$ & Cobrança de Pedágio em rodovias federais. \\
\hline $94 / 1989$ & Política Geral de Salários. \\
\hline $95 / 1989$ & Política do Salário Mínimo. \\
\hline $227 / 1990$ & $\begin{array}{l}\text { Doação de imóvel do Instituto Nacional de Colonização e Reforma Agrária - Incra à } \\
\text { Aeronáutica para casa própria a servidores civis e militares do Ministério da } \\
\text { Aeronáutica. }\end{array}$ \\
\hline $25 / 1991$ & $\begin{array}{l}\text { Recursos para estradas vicinais na região Centro-Oeste e para a instalação da Sede do } \\
\text { Tribunal Regional do Trabalho da 9a Região }\end{array}$ \\
\hline $52 / 1991$ & $\begin{array}{l}\text { Isenção do Imposto sobre Produtos Industrializados (IPI) na aquisição de automóveis } \\
\text { por pessoas portadoras de deficiência física. }\end{array}$ \\
\hline $168 / 1994$ & $\begin{array}{l}\text { Plano Real: paridade dos encargos dos financiamentos agrícolas com os prescos } \\
\text { mínimos monitorados pelo Governo. }\end{array}$ \\
\hline $38 / 2012$ & Partilha dos royalties do pré-sal entre todos os Estados. \\
\hline
\end{tabular}

Fonte dos dados brutos: Sistemas de Informação do Senado Federal e da Câmara dos Deputados, Diário do Senado Federal e do Congresso Nacional; Relatório Anual da Presidência do Senado Federal.

Verifica-se a concentração das ocorrências de rejeição nas duas primeiras legislaturas, o que permite antever a tendência de rejeição vinculada mais ao aspecto temporal do que ao tema tratado. Quanto a aspecto temporal não pareceu se tratar necessariamente de Presidentes “derrotados”, mas de uma acomodação do sistema de veto.

Dos quatro casos restantes, dois tratam de assuntos jurídicos e dois tratam de assuntos sociais. Dois deles tratam, na realidade, de matéria econômica, isenções fiscais referentes a microempresas e ao desporto. Um deles tratava de anistia a multas eleitorais relativos às eleições de 1996 e 1998. O outro registra um caso curioso de rejeição a veto com apoio do Presidente da República (Grohmann, 2003, para detalhes): o veto à esterilização voluntária de homens e mulheres na rede pública de saúde (Quadro 11):

Quadro 11: Vetos Rejeitados - Temas Jurídico e Social - Assuntos

\begin{tabular}{|c|l|}
\hline $\mathbf{N}^{\mathbf{0}}$ & \multicolumn{1}{c|}{ Assunto da Matéria Vetada } \\
\hline $16 / 1989$ & Isenção a microempresas de valores da tabela de registros de comércio \\
\hline $21 / 1989$ & Esterilização voluntária de homens e mulheres na rede pública de saúde \\
\hline $85 / 1996$ & Isenção fiscal de imposto de renda para incentivo ao desporto \\
\hline $5 / 2000$ & Anistia de multas eleitorais referentes às eleições de 1996 e 1998 \\
\hline
\end{tabular}

Fonte dos dados brutos: Sistemas de Informação do Senado Federal e da Câmara dos Deputados, Diário do Senado Federal e do Congresso Nacional; Relatório Anual da Presidência do Senado Federal. 
Reafirma-se a predominância das duas primeiras Legislaturas nos casos de rejeição.

Ao menos a duas conclusões se pode chegar quanto aos temas de vetos rejeitados no período estudado. Primeiramente, os casos dizem respeito a interesses econômicos de grupos, corporativamente organizados, invariavelmente com elevação de gastos públicos. Em segundo lugar, nota-se a concentração de vetos rejeitados nas duas primeiras legislaturas (Figura 21). Além disso, quanto ao tempo de tramitação, outra conclusão interessante é possibilitada pelos dados: o tempo de tramitação médio dos vetos rejeitados é de 84 dias, muito menor que o tempo de tramitação médio dos vetos mantidos, de 603 dias. Essa diferença é ainda mais acentuada se considerados apenas os vetos rejeitados nas duas primeiras legislaturas, quando era de 65 dias.

Figura 21: Gráfico de Vetos Rejeitados, classificados por legislatura.

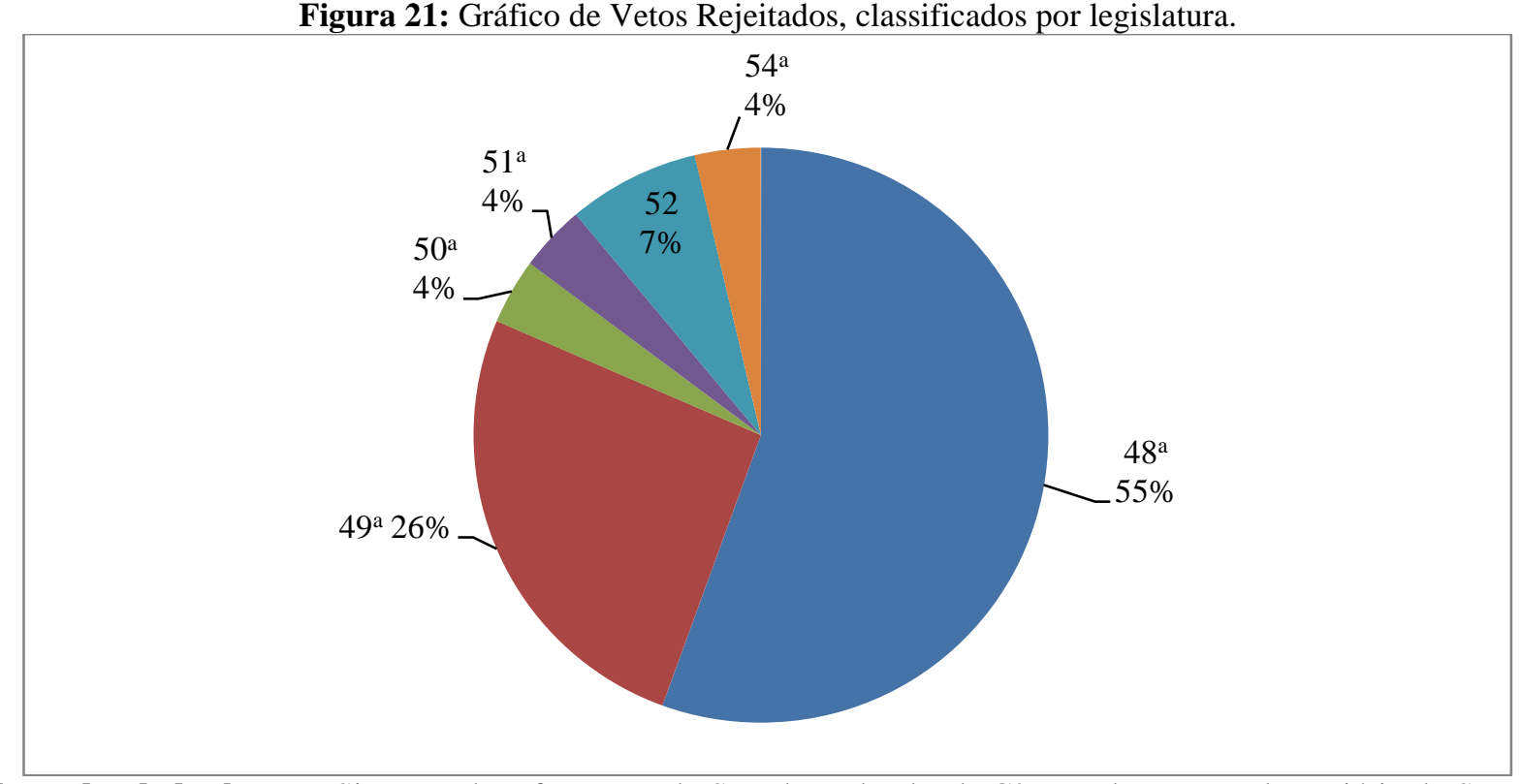

Fonte dos dados brutos: Sistemas de Informação do Senado Federal e da Câmara dos Deputados, Diário do Senado Federal e do Congresso Nacional; Relatório Anual da Presidência do Senado Federal.

Adicionalmente, o gráfico da Figura 22 a seguir ilustra a diferença quanto à legislatura de rejeição do veto, em relação à legislatura de manutenção. 
Figura 22: Gráficos de legislatura de apreciação do veto - conforme resultado

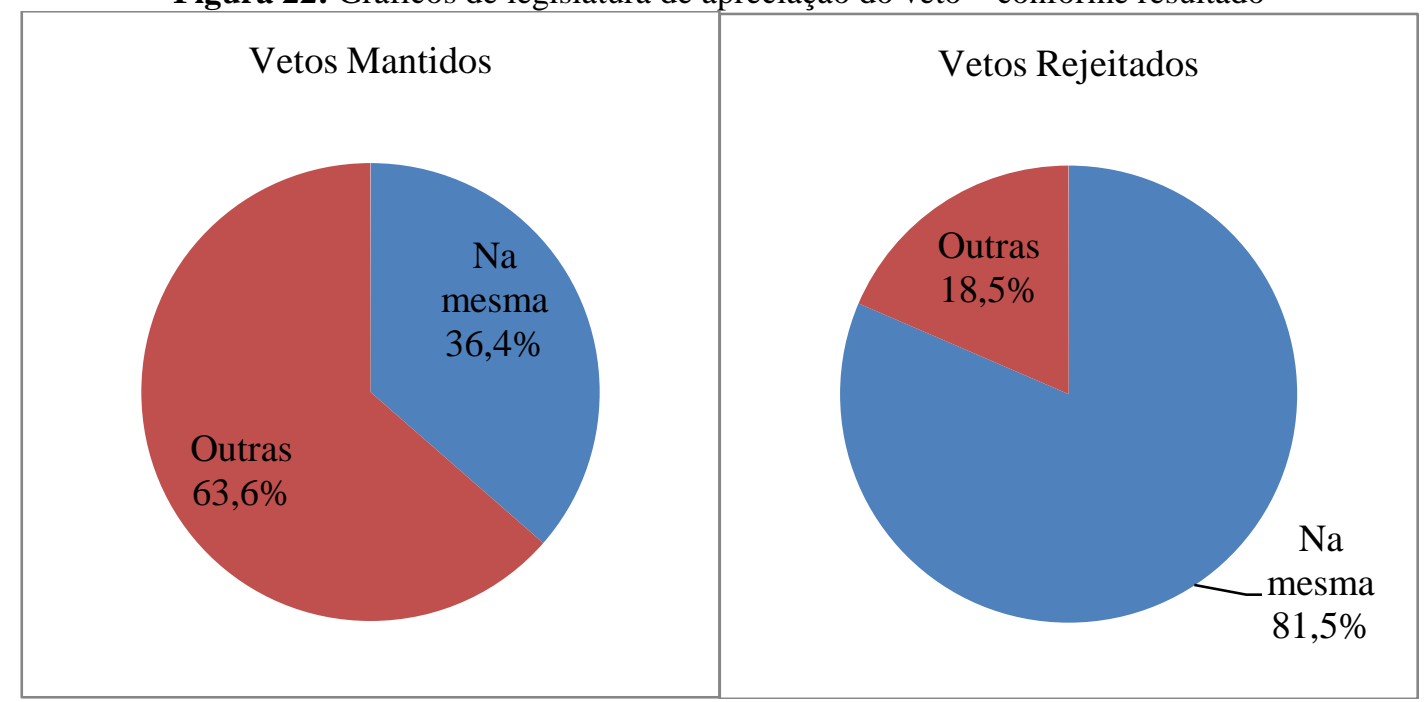

Fonte dos dados brutos: Sistemas de Informação do Senado Federal e da Câmara dos Deputados, Diário do Senado Federal e do Congresso Nacional; Relatório Anual da Presidência do Senado Federal.

Essa análise atesta o senso comum de que o tempo para a rejeição do veto é curto. Para que as forças políticas sejam acionadas na direção dos interesses de determinado grupo é preciso agir rápido. A conclusão contrária a essa é também útil: se uma matéria é de ordem universal, sem que se identifiquem para ela grupos específicos interessados, não há rejeições. As únicas exceções que se identificam são os vetos do Presidente José Sarney nas matérias que tratavam de políticas salariais, mas é mais uma questão de dimensão do que de natureza, já que se trata do interesse geral dos trabalhadores.

A distribuição dos vetos, por tipo, também difere quanto aos períodos, conforme o gráfico da Figura 23 ilustra. Mas houve mais vetos totais (17) rejeitados do que parciais (10), o que fortalece a argumentação em favor do fator temporal como explicativo das rejeições a vetos, mais que do fator assunto. A elevação da quantidade de vetos parciais acentuou-se, ao passo que a quantidade de rejeições caiu, talvez porque no veto parcial ocorrem mais transigências. 
Figura 23: Gráficos de vetos rejeitados por tipo e períodos.

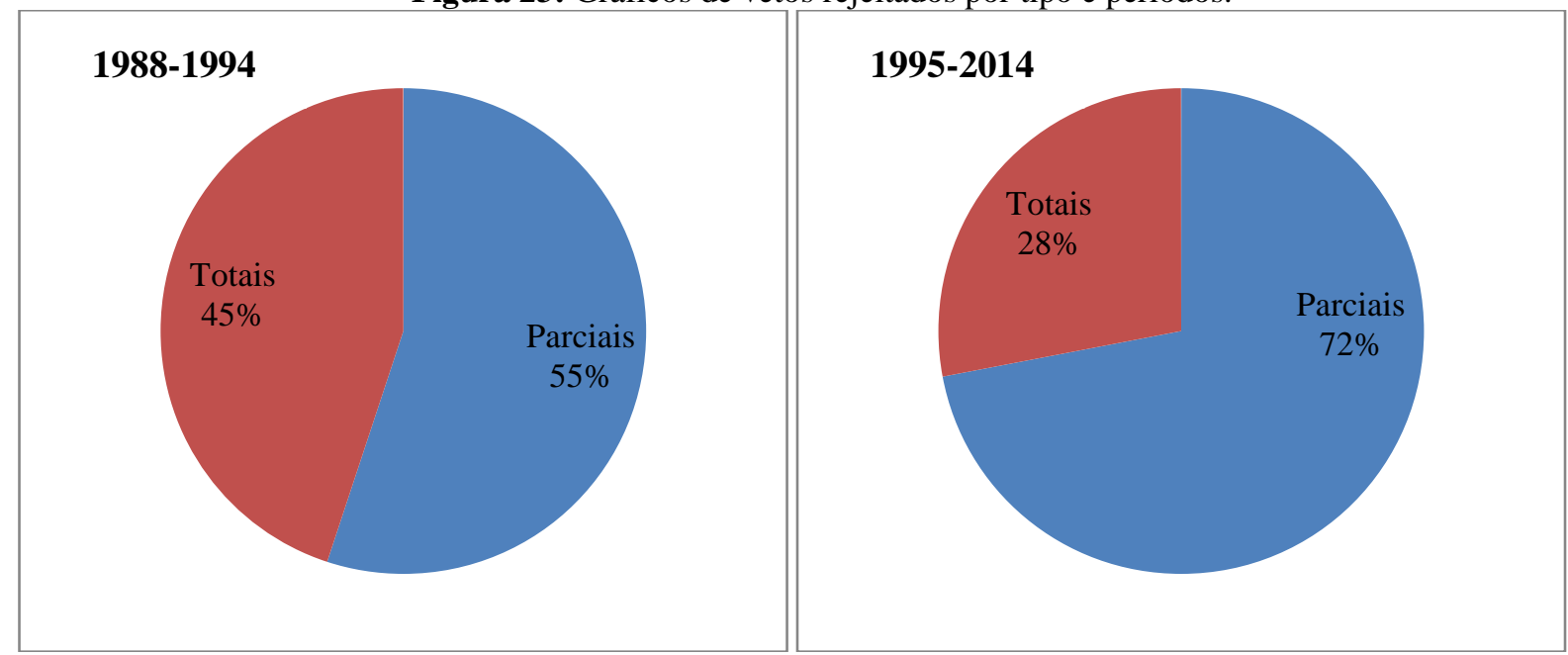

Fonte dos dados brutos: Sistemas de Informação do Senado Federal e da Câmara dos Deputados, Diário do Senado Federal e do Congresso Nacional; Relatório Anual da Presidência do Senado Federal.

Para outra explicação para a divisão entre esses dois períodos (1988-1994 e daí por diante) poder-se-ia empregar a literatura pátria sobre Congresso e, juntamente com Grohmann (2003), Lamounier (2005) e Moya (2005) concluir sobre a importância da variável coalizão sobre o veto. Embora não haja grandes variações de disciplina para todas as coalizões formadas pelos presidentes brasileiros desde 1988, é sabido que os Presidentes José Sarney e Fernando Collor, os que mais sofreram rejeições a seus vetos, contavam com menor apoio no Congresso (SANTOS, 2006). Ao mesmo tempo, eram os que mais utilizavam o veto total. Essa inflexibilidade, característica do veto total, pode ser vista também como simples tradução do modo clássico de separação dos poderes, expresso no exercício do veto, que inauguravam o uso do aparato institucional recém-inaugurado.

Enquanto o sistema se acomodava, mais frequentes eram os vetos parciais e menos frequentes as rejeições aos vetos. Isso foi se invertendo. A solução explícita, que, de acordo com a literatura pesquisada, tanto fortalece os institutos quanto enfraquece os governos, foi cedendo espaço à solução implícita que, segundo as mesmas fontes, enfraquece os institutos e piora a avaliação de desempenho do Legislativo, em favor de certa visão de governo. 


\subsection{Quase rejeição e vetos mútuos.}

Chama a atenção, ainda, o fenômeno da quase rejeição. Trata-se de vetos que, tendo sido rejeitados na Câmara dos Deputados, não foram rejeitados no Senado. São precisamente seis casos ocorridos, conforme Quadro 12.

Quadro 12:Vetos Rejeitados pela Câmara e Mantidos pelo Senado

\begin{tabular}{|c|c|l|}
\hline \multicolumn{1}{|c|}{$\mathbf{N}^{\mathbf{0}}$} & Tipo & \multicolumn{1}{c|}{ Assunto da material vetada } \\
\hline 209/1989 & Parcial & $\begin{array}{l}\text { Criação de Cargo de Ministro para a Coordenadoria Nacional para a Integração da } \\
\text { Pessoa Portadora de Deficiência }\end{array}$ \\
\hline $118 / 1990$ & Parcial & Política Nacional de salários \\
\hline 151/1990 & Total & Planos de Benefícios da Previdência Social \\
\hline 25/1991 & Parcial & $\begin{array}{l}\text { Lei Orçamentária para 1991:130 milhões de cruzeiros para a ponte Barreiros, entre } \\
\text { os Municípios de Samaritá em São Vicente - SP }\end{array}$ \\
\hline 23/2013 & Parcial & $\begin{array}{l}\text { Isenção de PIS/PASEP e Cofins na produção de escovas de dentes, incluindo as } \\
\text { próprias para dentaduras, absorventes, tampões higiênicos e fraldas para bebês e } \\
\text { geriátricas e de sal }\end{array}$ \\
\hline
\end{tabular}

Fonte dos dados brutos: Sistemas de Informação do Senado Federal e da Câmara dos Deputados, Diário do Senado Federal e do Congresso Nacional; Relatório Anual da Presidência do Senado Federal.

Esse fenômeno atesta uma característica marcante do processo decisório legislativo bicameral conjunto, que é o caso do veto: os vetos mútuos. Caso esses seis vetos tivessem sido rejeitados teria ocorrido o aumento no universo de rejeições em $20 \%$. Pelos temas tratados, o efeito prático teria sido considerável, uma vez que, novamente, os projetos tratam predominantemente de interesses de grupo com reflexos nos gastos públicos.

Ressalte-se, ainda, que esse tipo de veto é exercido com muito mais frequência pela Câmara. Como a grande maioria das matérias vetadas tem aquela Casa como iniciadora, a 
apreciação de vetos também se inicia por ela. Como a regra ${ }^{22}$ estabelece que, mantido o veto em uma das Casas, dispensa-se a votação (apuração) na outra Casa, não é possível aferir quais vetos teriam sido rejeitados pelo Senado, caso fosse essa a vontade de sua maioria.

Por essa razão não é possível verificar casos de quase rejeições de vetos mantidos pela Câmara depois de terem sido rejeitados pelo Senado. O quórum negativo - ou quórum para rejeição - pode resultar em um sistema de vetos mútuos entre as Casas, atuando, via de regra, em favor da manutenção dos vetos presidenciais. Ao mesmo tempo, como visto em Grohmann (2003), talvez se possa atribuir essa dinâmica ao quórum de maioria absoluta para rejeição do veto.

A teoria dos atores com poder de veto, desenvolvida por Tsebelis (2009), identifica esse “impasse” como “estabilidade decisória”, que é a dificuldade de se modificar consideravelmente o status quo, determinado tanto pela quantidade de atores com poder de veto quanto pelas distâncias entre as preferências dos atores. Trata-se de atores institucionais de veto, típicos do bicameralismo.

Descritos os vetos e estabelecidos alguns pressupostos, pode-se afirmar que o veto típico é parcial, aposto a um projeto de lei de iniciativa do Legislativo, com temática social, ou do Executivo com temática econômica, alterado pelos legisladores, apreciado depois de mais de dois anos de tramitação, mantido, pela metodologia da cédula, e jamais chega a trancar a pauta das sessões conjuntas, no período estudado.

${ }^{22}$ Ver item 5.6 para melhor compreensão dessa regra. 